
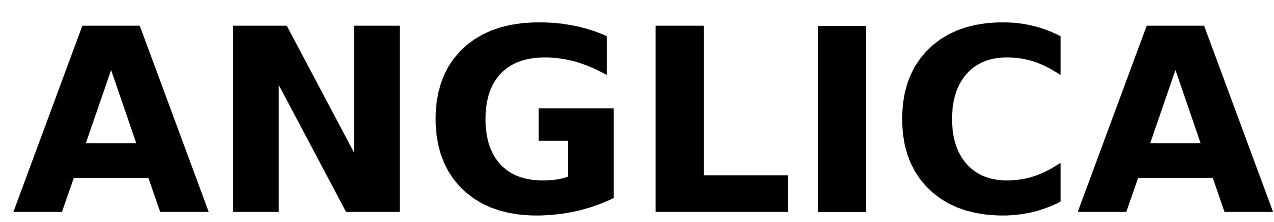

\title{
An International Journal of English Studies
}

\section{Special Issue: The Great War}

\section{$27 / 32018$}

\author{
EDITOR \\ Grażyna Bystydzieńska [g.bystydzienska@uw.edu.pl] \\ ASSOCIATE EDITORS \\ Martin Löschnigg [martin.loeschnigg@uni-graz.at] \\ Jerzy Nykiel [jerzy.nykiel@uib.no] \\ Marzena Sokołowska-Paryż [m.a.sokolowska-paryz@uw.edu.pl] \\ Anna Wojtyś [a.wojtys@uw.edu.pl] \\ ASSISTANT EDITORS \\ Magdalena Kizeweter [m.kizeweter@uw.edu.pl] \\ Katarzyna Kociołek [kkociolek@uw.edu.pl] \\ Przemysław Uściński [przemek.u@hotmail.com] \\ ENGLISH LANGUAGE EDITOR \\ Barry Keane [bkeane@uw.edu.pl]
}

ADVISORY BOARD

Michael Bilynsky, University of Lviv Andrzej Bogusławski, University of Warsaw Mirosława Buchholtz, Nicolaus Copernicus University, Torun

Edwin Duncan, Towson University

Jacek Fabiszak, Adam Mickiewicz University, Poznań Jacek Fisiak, Adam Mickiewicz University, Poznań Elżbieta Foeller-Pituch, Northwestern University, Evanston-Chicago Piotr Gąsiorowski, Adam Mickiewicz University, Poznań

Keith Hanley, Lancaster University Andrea Herrera, University of Colorado Christopher Knight, University of Montana, Marcin Krygier, Adam Mickiewicz University, Poznań

Krystyna Kujawińska-Courtney, University of Łódź

Brian Lowrey, Université de Picardie Jules Verne, Amiens Zbigniew Mazur, Maria Curie-Skłodowska University, Lublin Rafał Molencki, University of Silesia, Sosnowiec John G. Newman, University of Texas Rio Grande Valley Michal Jan Rozbicki, St. Louis University Jerzy Rubach, University of Iowa

Piotr Ruszkiewicz, Pedagogical University, Cracow Hans Sauer, University of Munich Krystyna Stamirowska, Jagiellonian University, Cracow Merja Stenroos, University of Stavanger Jeremy Tambling, University of Manchester Peter de Voogd, University of Utrecht Anna Walczuk, Jagiellonian University, Cracow Jean Ward, University of Gdańsk Jerzy Wełna, University of Warsaw

\section{GUEST REVIEWERS}

Stephen Badsey, University of Wolverhampton Jason Crouthamel, Grand Valley State University, Allendale Dagmara Drewniak, Adam Mickiewicz University, Poznań Brigitte Glaser, University of Göttingen Sherrill Grace, University of British Columbia Rob Johnson, Pembroke College, Oxford Bożena Kucała, Jagiellonian University, Cracow Peter Leese, University of Copenhagen David Malcolm, University of Gdańsk Marek Paryż, University of Warsaw Jane Potter, Oxford Brookes University Daniel Reynaud, Avondale College of Higher Education Ralf Schneider, Bielefeld University Christina Spittel, University of New South Wales, Canberra Jonathan Vance, Western University, London, Ontario

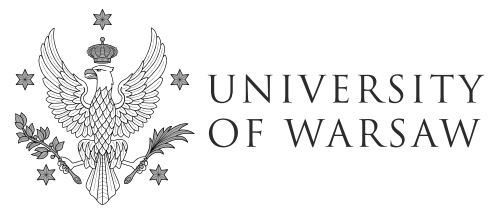


Anglica. An International Journal of English Studies

ISSN 0860-5734

www.anglica.ia.uw.edu.pl

Publisher:

Institute of English Studies University of Warsaw

ul. Hoża 69

00-681 Warszawa

Nakład: 40 egz.

Copyright (C) 2018 by Institute of English Studies University of Warsaw All rights reverved.

Typesetting:

Dariusz Górski

Cover design:

Bartosz Mierzyński

Printing and bindings:

Sowa - Druk na życzenie

www.sowadruk.pl

+48224318140 


\section{TABLE OF CONTENTS}

\section{INTRODUCTION}

Marzena Sokolowska-Paryż

Why and How Should We 'Remember' the Great War?

5

\section{ARTICLES}

Marjorie Gehrhardt

Mobilising the Red Cross Journal: A Charity's Periodical in Wartime

\section{Sara Prieto}

"War song of America": The Vigilantes and American Propagandistic Poetry of the First World War

\section{Natalia Stachura}

British Film Propaganda in the Netherlands: Its Preconditions and Missed Opportunities

\section{Anne Samson}

The End of the 1914-1918 War in Africa

\section{Donna Coates}

Happy is the Land that Needs No Heroes

\section{Martin Löschnigg}

How to Tell the War? Trench Warfare and the Realist Paradigm in First World War Narratives

\section{Nancy Sloan Goldberg}

From Barbusse to Lemaitre: The Evolution of Experience

\section{Anna Branach-Kallas}

World Travellers: Colonial Loyalties, Border Crossing and Cosmopolitanism in Recent Postcolonial First World War Novels

\section{Rūta Šlapkauskaitė}

"Like being trapped in a drum": The Poetics of Resonance in Frances Itani's Deafening 
Ross J. Wilson

Witnessing the Great War in Britain: Centenaries and the Making of Modern Identities

\section{REVIEW}

Anna Branach-Kallas and Piotr Sadkowski

Comparing Grief in French, British and Canadian Great War Fiction (1977-2014) (Katarzyna Więckowska)

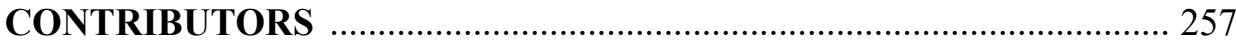




\section{INTRODUCTION Why and How Should We 'Remember' the Great War?}

In his alternate history novel After Dachau, Daniel Quinn envisages a chilling dystopian reality two thousand years after the Second World War. The most meaningful scene is set in a history class during which it becomes clear that for both the teacher and the students the battle of Verdun has as little meaning as the battles of Thermopylae and Hastings (120). Despite its ostentatiously implausible plot, Quinn's novel poses the highly relevant question of the impact of an inevitable and ever-increasing temporal distance on the significance of historical events for contemporary and future generations. In other words, how are societies to 'remember' their past if there is no one left who actually remembers it? Quinn conjures a disturbing fictional world in which "no one cares" (217) about history because any type of community (be it ethnic, social, or national) without memory is bound to be epistemologically and empathetically disconnected from its own historical heritage. Thus, the protagonist, Jason Tull, embarks on a self-appointed mission to 'unbury' whatever memory-traces can still be found, including photographs and paintings, as well as diaries and novels. The gallery that he creates, where he puts on display both the documents and the art of a long-forgotten past, may be interpreted as an attempt to construct - albeit only symbolically a "cultural memory" for his society.

The passing away of the 'Last Veteran[s]' of the Great War hit both the national and international news, each official announcement inevitably accompanied by remarks underscoring that these deaths signify far more than just a personal loss for the family involved: "We have come to the end of a chapter in history" ("Last living U.S. World War I veteran dies"); "Babcock is our last personal connection to a remarkable generation of Canadian heroes" ("Canada's last known Great War veteran, dies at age 109"); "Florence Green, the world's last surviving First World War veteran has died, marking the end of an era in British history" ("Last surviving veteran of First World War dies aged 110") (emphases mine). These deaths are thus depicted to be the (symbolic) demarcating moments of our time, prompting also the urgent questions of, first, how to preserve and perpetuate a 'memory' of the Great War when the beholders and guardians of its authentic and living memory are forever gone, and, second, how to endow this war with a contemporary relevance that would allow "the past [to] be reclaimed as "ours" (Assmann 113). There appears to be a general consensus, as Jan Assmann writes, 
that "knowledge about the past [needs to acquire] the properties and functions of memory" and - in order to do so - it must be "related to the concept of identity" (113). This "identity" needs to be considered in both its national and transnational/ global variants, with an awareness of the multifarious facets (geopolitical, sociopolitical, military, legal, medical, psychological, anthropological, philosophical, or cultural) determining the dominant epistemologies and ideologies of war.

It does not suffice to simply disseminate the basic facts about the Great War, for example, by means of the educational system. One may ask - so what if students know that the First World War took place in 1914-1918? This is just a date. A teacher wanting to create an affective shock may quote the numbers constituting the "unprecedented losses" of the Great War: "Germany lost more than 1.8 million, Russia 1.7 million, France 1.3 million, Austria-Hungary 922,000, Italy 460,000, the USA 50,500, Bulgaria 75,000, [...] Britain 888,000, Canada 65,000 , Australia $62,000[\ldots]$," even adding that "these figures were approximately 50 per cent greater than for the Second World War" (Haythornthwaite 54) - yet these are just statistics. And why should contemporary and future generations read and/or watch the 'documents of the imagination' of that time (letters, diaries, memoirs, poetry, fiction, drama, film)? The knowledge of the facts of the Great War (dates, battles, adversaries, and also the culture of the period) is meaningless if not cognitively and ideologically embedded within contexts that will allow us to see how many aspects of our contemporary reality have their roots in what happened a hundred years ago, and if not affectively contextualized by authentic or imagined stories of personal experiences.

To speak of an enduring fascination with a military conflict that took place a hundred years ago would be an overstatement. It is more accurate to say that one can detect impressive institutional, scholarly and cultural efforts to perpetuate an empathetic understanding of the countless and varied human experiences in the time of the Great War, as well as an awareness of the scale of its geopolitical impact and the vastness of the social changes it brought into being, giving birth to the modern age. In the words of Modris Eksteins, to look back to the Great War demands of us to consider the various forms of "[our] becoming," and "the emergence, in the first half of [the twentieth] century, of our modern consciousness" (xiii). The proliferation of histories and documentaries, academic studies and popular literature and film, museum exhibitions and information centres at memorial sites, the adherence to annual commemorative ceremonies and the erection of new monuments all serve to 'undo' the inevitable processes of 'forgetting' the past and to diminish the "historical distance" dividing the 'then' of 1914-1918 from the 'now' of the twenty-first century. They serve to "make the historical scene as vivid and palpable as possible" by representing it as "a place of [possible] emotional or ideological engagement" (Phillips 92).

It is the purpose of "cultural memory" to convince us of the relevance of the past for the 'here and now,' i.e. to effectively situate historical events within 
"[our] temporal horizon" (Assmann 113). In Jan Assmann's definition, "cultural memory" is "exteriorized, objectified, and stored away in symbolic forms," and it needs to be "supported by [...] institutions of learning, transmission and interpretation; $[\ldots]$ cultivated by specialists and $[\ldots]$ celebrated on special occasions" (111). Despite the advantages of globalization that allow for an unlimited access to the "histories' of other nations, "cultural memories" tend to be "local, egocentric, and specific to a group and its values" (113). Thus, there is no one "cultural memory" of the Great War but multiple modes of its memorialization and representation across different nations. This can best be seen in the different designations for the November 11 commemorations as Remembrance Day (as in the Commonwealth of Nations) or Independence Day (as in Poland), which suggest strikingly different interpretations of the First World War. Remembrance Day is all about pausing to think of the dead of the Great War, the extent of the loss of human life morally superseding the fact of these nations having achieved a military victory. Independence Day signifies a different hierarchy of meaning, where national freedom is considered a superior ethical category to the deaths of millions.

The positive impact of "historical distance" is such that it allows for "the possibility of new [...] perspectives that are conferred by the passage of time," i.e. "there is much we can see about [the past] that was difficult to understand and speak about at the time" (Phillips 91). Though in varying degree, different "cultural memories" of the Great War have been strongly affected by feminist, postcolonial, memory and trauma theories, the impact of which is most clearly visible in the reshuffling of the epistemological focus in contemporary (postmemory) museums and memorials, literature and film, as well as academic studies. National, social, ethnic and gender-related identities in the present demand a re-evaluation of the representations of these identities in the past, such as for instance 'unforgetting' women's experience, 'undoing' the absence of Indigenous people in the "cultural memory" of the First World War, or depicting civilian grief to be cognitively as significant as soldiers'/veterans' trauma. It is beyond doubt that today's sociological and ethical concerns have resulted in an interest in the (non)meaning of social class, race and gender in the construction of 'memories' of the Great War in the time of the conflict and its aftermath, accompanied by efforts to bring these hitherto suppressed issues to the forefront of contemporary attention. One may also detect a tendency towards restoring the significance of the 'fields' of the Great War that had been overshadowed by the overwhelming focus on trench warfare in France and Flanders, ranging from the renewed interest in the Armenian genocide to the 'forgotten' fronts of Eastern Europe or Africa.

One may speak here of the phenomenon of belatedness which effectively re-structures the prevailing modes of cultural 'remembering.' Within the context of "cultural memory," belatedness can be compared to the effect of creating a new work of art as put forth by T. S. Eliot: "The existing monuments form an 
ideal order among themselves, which is modified by the introduction of the new (the really new) work of art among them. The existing order is complete before the new work arrives; for order to persist after the supervention of novelty, the whole existing order must be, if ever so slightly, altered; and so the relations, proportions, values of each work of art toward the whole are readjusted; and this is conformity between the old and the new" (2207-2208). Belatedness should thus be understood as the cognitive, affective, and ideological impact of the construction(s) of various post-memory forms of commemoration, as well as cultural and scholarly representations. Their aim has been to foreground aspects of a long-past historical event which were ignored within the commemorative and representational modes of their 'own' period, due to the socio-political and cultural restrictions at that specific time and the prevailing ideological frameworks for interpreting the Great War in a given nation.

The appearance of a 'belated' memorial, text, film or historical study concomitantly testifies to the absence of their allegedly 'new' subject of commemoration, representation and study in the mnemonic forms hitherto accepted as canonical, forcing one to reassess their place in the hierarchy of meaning for an understanding of the Great War and its impact on ethnic, social, gender or national identities. One may cite here the telling example of the 1995 "Never Forget" memorial by John Boxtel, commemorating the Ukrainian-Canadians detained in internment camps during the Great War. The very existence of this new memorial has irrevocably changed the Canadian 'memorialscape' by adding a sense of national guilt to the hitherto dominant myth of "the birth of a nation" (see Vance 68-112) as carved by Walter Allward into his Canadian National Vimy Memorial (unveiled in 1936). Every post-memory memorial, museum exhibition, documentary, popular film, novel, poem or drama; the re-publications of wartime or interwar historical, documentary and literary texts up till now 'absent' within the accepted national canons; or scholarly studies focusing on hitherto suppressed aspects of the 1914-1918 conflict ranging from 'forgotten' battlefields beyond the Western Front to the specific topics of facially disfigured soldiers or women's grief - all these have set the grounds for redefinitions, revaluations, restructurings and re-orderings within the dominant schemata of "cultural memories" of the First World War.

In the words of Pierre Nora, when "there is no spontaneous memory," it is necessary to "create archives, maintain anniversaries, organize celebrations, pronounce eulogies, and notarize bills because such activities no longer occur naturally" (12). However, "[societies] without ritual" (Nora 12) open the door to creating new rituals, new forms of commemoration, and new forms of representation. And the phenomenon of belatedness inevitably draws attention to "cultural memory" itself, prompting the questions as to how it differs from wartime and inter-war representational strategies - and thus how it (potentially) alters our contemporary understanding of the epistemological and ideological undercurrents determining the mnemonic forms of a past historical period. Expanding on Ann 
Rigney's typology, the contemporary drive to scrutinize the "cultural memory" of the Great War can been seen as performing several functions. The question that needs to be asked regards the extent to which the various modes of "cultural memory" (institutional, educational, architectural, academic, literary, or filmic) serve the purposes of "relay stations, [...] recycl[ing] earlier forms of remembrance" and "stabilizers, [...] celebrat[ing] [...] 'monuments' from the past," as opposed to being "catalysts, [...] drawing attention to "new' topics or ones hitherto neglected in cultural remembrance" and "calibrators, [...] reflecting critically on dominant memorial practices" (350-351).

The centenary of the Great War provides the perfect opportunity not only to reassert the significance of this first global-scale conflict of the twentieth-century for contemporary generations in light of its numerous cultural representations but also to highlight the epistemological and interpretative diversity surrounding the subject of the war that has emerged in the recent decades. It was the choice of our editorial team to include articles that altogether attest to a desirable centrifugality at the core of cultural memory. The Great War should be understood as a 'site' of myriad combatant and civilian experiences, social and political processes, geopolitical turmoil and repercussions; as well as a 'site' of conflicting ideologies and mythologies. The 'stories' about the Great War that emerge from the different articles included in this special issue do not add up to a unified 'image' of the Great War, showing instead that there is no one 'truth' of this military conflict but innumerable 'truths' and 'untruths.' An understanding of this war in all its complexity, as Jules Romains so aptly wrote in his 1938 novel Verdun, requires a simultaneous "seeing' through both the "microscopic" and "telescopic" lens (36). Hence our decision to include articles that deal with the 'documents' of the time as well as texts offering an analysis of the 'vastness' of the historical and mythopoeic processes that took place, concomitantly mapping unchartered 'territories' within Great War studies and critically reassessing the hitherto dominant representational paradigms in comparison to post-memory forms of writing, showing, and commemorating this historically distant conflict.

The articles are ordered so as to underscore the most important trends comprising a multifarious "cultural memory" of the First World War. The opening and closing articles were deliberately chosen to form a framing of the entire issue, beginning with a scrutiny of a document from the past (Marjorie Gehrhardt's "Mobilising the Red Cross Journal: A Charity's Periodical in Wartime") and concluding with an analysis of contemporary commemorative practices (Ross J. Wilson's "Witnessing the Great War in Britain: Centenaries and the Making of Modern Identities"). Within this interpretative frame 'from document to monument,' the articles are arranged so as to highlight the necessity to also acknowledge the successes and failures of the propaganda efforts undertaken during 1914-1918 to ensure either national or transnational support for the military effort, propaganda being a 'battlefield' as significant as the combat zones (Sara Prieto's "'War song 
of America': The Vigilantes and American Propagandistic Poetry of the First World War" and Natalia Stachura's "British Film Propaganda in the Netherlands: Its Preconditions and Missed Opportunities"). The subsequent texts serve to highlight the distinction between the actual geopolitical repercussions of the Great War versus the constructions of mythopoeic national identities (Anne Samson's "The End of the 1914-1918 War in Africa" and Donna Coates's "Happy is the Land that Needs No Heroes"). One cannot ignore the reasons for which inter-war (documentary and fictional) literary accounts written by male veterans of the Great War came to be seen as the dominant representative 'truth' of the conflict (Martin Löschnigg's "How to Tell the War? Trench Warfare and the Realist Paradigm in First World War Narratives"), yet it is also essential to see that historical distance does not necessarily affect the accuracy of the depiction of the human experience of war (Nancy Sloan Goldberg's "From Barbusse to Lemaitre: The Evolution of Experience"). The re-writings of the First World War in post-memory fiction have paved the way for substantial re-interpretations of the social and political meanings of the conflict from the perspective of fictional protagonists representing a range of human experiences missing from the accepted canonical war narratives (Anna Branach-Kallas's "World Travellers: Colonial Loyalties, Border Crossing and Cosmopolitanism in Recent Postcolonial First World War Novels" and Rūta Šlapkauskaite's “'Like being trapped in a drum': The Poetics of Resonance in Frances Itani's Deafening"). Pertinently, our special issue thus ends with an article on post-memory forms of commemoration, so as to accentuate that the "cultural memory" of the Great War is our only venue to an understanding of what happened in 1914-1918. This 'understanding' is inevitably filtered through contemporary perspectives that aim to prove the ethical relevance of past representations of the war for our 'here and now.' All the articles comprising our special issue aim to answer the vital question put forth in the subtitle for this introduction, namely, why and how should we remember the Great War a hundred years after it occurred?

Marzena Sokołowska-Paryż
(iD) https://orcid.org/0000-0001-6775-9327

\section{References}

Assmann, Jan. 2010. "Communicative and Cultural Memory." A Companion to Cultural Memory Studies. Ed. Astrid Erll and Ansgar Nünning. Berlin and New York: De Gruyter. 109-118.

"Canada's last known Great War veteran, dies at age 109." 2010. Global News. https://globalnews.ca/news/84836/john-babcock-canadas-last-known-greatwar-veteran-dies-at-age-109/ 
Eksteins, Modris. 2000. Rites of Spring: The Great War and the Birth of the Modern Age. Boston and New York: A Mariner/Peter Davison Book - Houghton Mifflin Company.

Eliot, T. S. 1986. "Tradition and the Individual Talent." The Norton Anthology of English Literature. $5^{\text {th }}$ Edition. Vol. 2. New York and London: W. W. Norton \& Company. 2206-2213.

Haythornthwaite, Philip J. 1993. The World War One Source Book. London: Arms and Armour Press.

Quinn, Daniel. 2001. After Dachau. Hanover, New Hampshire: Zoland Books.

"Last living U.S. World War I veteran dies." 2011. CNN. http://edition.cnn. com/2011/US/02/27/wwi.veteran.death/

"Last surviving veteran of First World War dies aged 110." 2018. The Telegraph. https:/www.telegraph.co.uk/news/uknews/9066371/Last-surviving-veteranof-First-World-War-dies-aged-110.html

Nora, Pierre. 1989. "Between Memory and History: Les Lieux de Mémoire." Representations 26: 7-24.

Phillips, Mark Salber. 2006. "History, Memory, and Historical Distance." Theorizing Historical Distance. Ed. Peter Seixas. Toronto: Toronto University Press. 86-103.

Rigney, Ann. 2010. "The Dynamics of Remembrance: Texts Between Monumentality and Morphing." A Companion to Cultural Memory Studies. Ed. Astrid Erll and Ansgar Nünning. Berlin and New York: De Gruyter. 345-353.

Romains, Jules. 2000 [1938]. Verdun. Trans. Gerard Hopkins. London: Prion Books. Vance, Jonathan F. 2012, Maple Leaf Empire: Canada, Britain and the Two World Wars. Oxford: Oxford University Press. 

Marjorie Gehrhardt

(iD https://orcid.org/0000-0002-8880-4286

University of Reading

\title{
Mobilising the Red Cross Journal: A Charity's Periodical in Wartime
}

\begin{abstract}
The first issue of the Red Cross Journal was published in January 1914, only eight months before the outbreak of the First World War. This article explores the impact of the war on this publication, as the work of the charity it represented dramatically expanded over the course of the conflict. How did the Journal survive the war, at a time when the Red Cross was deeply involved in supporting soldiers? This article examines the genesis of this publication and its evolving role during the war. This periodical, we argue, not only helped raise awareness of the work carried out by the Red Cross, but it also served practical purposes in the areas of training and funding. This publication reveals an increasingly critical stance towards the British Empire's enemies in the war, as well as the need for the British Red Cross Society to foster a sense of unity amongst members posted around the world.
\end{abstract}

\section{Relief Work in the First World War: A Brief Overview}

The Centenary years have seen a growing interest in the role of philanthropic organisations during the First World War and its aftermath. A 2014 special issue of the First World War Studies, devoted to humanitarianism, highlights the "innovative humanitarian countermeasures" (Little 1) that emerged in response to the material and human destruction caused by the conflict. In his introduction to this special issue, Brendan Little underlines some of the challenges faced by relief organisations, including "fierce internal debates within their own organisations and bitter fights with rival relief agencies," and sometimes also with state agencies (2). The present article makes a contribution to this emerging history of philanthropy in the First World War, while also furthering our understanding of the Home Front and of the agents involved in providing medical care during the conflict. It focuses on one such relief agency, the British Red Cross Society (hereafter BRCS), and its involvement in the Great War as narrated in a littleresearched source: the organisation's monthly newspaper, the Red Cross Journal. While some of the difficulties identified by Little, such as developing good working relationships with the War Office, had been addressed by the BRCS before 1914, 
the question of collaboration with other relief agencies had to be tackled as soon as the war started.

The wartime work of the BRCS also raises questions pertaining to the struggle between maintaining a neutral approach to wartime relief, and relying on volunteers and funds from a country actively engaged in the war. How did the journal run by the national branch of a neutral organisation (the International Red Cross Committee) write about a war in which Great Britain was involved? This analysis of the Journal charts the development of a patriotic discourse as the war progressed while also examining how the BRCS presented itself to its individual members through the medium of the Journal. In his study of voluntary action in the First World War, Peter Grant stresses the collaboration between state and relief agencies, while Jessica Meyer's work on medical voluntarism underlines the "complex and contested relationship between the two" (108). If Meyer's analysis reinforces Grant's interpretation of the Great War as asserting “the state's domination of voluntary medical relief" (Meyer 108), she also stresses the tensions, past and contemporary to the outbreak of the Great War, between and military authorities and the British Red Cross Society. Moreover, disagreements within the BRCS itself, according to Meyer, were not uncommon (109). While these studies focus largely on the negotiation of relationships between governmental bodies such as the Army Medical Services, and voluntary organisations, the present article is concerned with the discourse on the war produced by one specific society, and with the way it envisioned and narrated its own role in the conflict. Where Meyer's study focuses more on male protagonists, this article charts the growing significance of female BRCS members. How, then, did the British Red Cross Society respond to the outbreak of the war? How did its work evolve throughout the conflict? This article explores the changes within the British Red Cross Society as it adapted to wartime conditions, and expanded the scope of its intervention.

The function of the Red Cross Journal as a medium and, we argue, a communication tool bridging geographical and experiential gaps arisen from the war, will also be considered. At a time when newspapers were changing rapidly, becoming lucrative commercial ventures under the influence of Lord Northcliffe (Williams 138), the Red Cross Journal fulfilled a different function from mainstream newspapers. While no archival records remain to help us ascertain the nature and size of its readership, most issues of the Journal have been kept between the Bodleian Library, the British Library and the British Red Cross Archives; the study of this periodical, and notably the editorial notes, gives some indication as to its success and its expanding target audience. While trench newspapers and aspects of wartime print culture such as censorship and propaganda are receiving increasing scholarly attention, the Red Cross Journal differs notably from such publications. The BRCS newspaper shares some similarities with trench publications insofar as it helped reinforce cohesion among members of a specific group (Fuller 13). 
However, its durability, the conditions of its production, its target audience and the news it focussed on set the Red Cross Journal apart from both mainstream newspapers and trench publications. This article, based on a survey of the evolution of the key themes and sections featured in the 1914-1921 (and especially 1914-1918) issues of the Red Cross Journal, will therefore examine the singular position occupied by this publication, with special emphasis on the functions fulfilled by the Journal during the war, functions which justified, in the eyes of the Red Cross, continued investments of time and money at a time when most of the society's financial and human resources were required to provide relief.

\section{The Red Cross Journal Goes to War}

The first issue of the Red Cross Journal was published in January 1914, over forty years after the first foundations of this charity were laid. The British National Society for Aid to the Sick and Wounded in War was created in 1870 to provide relief in the Franco-Prussian war; several other societies were set up later, such as St John's Ambulance Brigade in 1887. In 1898 the Central British Red Cross Committee was founded, in "an attempt by the War Office to ensure both closer co-operation with the Army Medical Service and to prevent any overlapping in duties" (Carrington 13). This effort at coordinating aid work was however not entirely successful, and his experience in the South African War prompted Sir John Furley, then Representative of the Red Cross Society in South Africa, to write on 29 October 1900:

We all know what a scramble there was for costly and unorganized assistance sent out under more or less authority, and how funds were collected, some for the purpose of aiding the hospitals; whilst others, with less defined limits, only increased the waste and confusion. [...] The position of the Central British Red Cross Committee should at once be made known throughout the Empire, and no societies or individuals should be allowed to aid the sick and wounded except through the one recognized channel. (qtd. in Best 96)

Furley's call for a single charity to coordinate the provision of relief was echoed in a Royal Commission report, in which the authors highlight that "there must have been some waste owing to the overlapping of the various charities and charitable gifts" and recommend that "[i]n future wars it would be advisable, if possible, that some provision should be made by which all charitable gifts should be received and dealt with by one organised body" (Report 16). This criticism was expressed at a time when Great Britain was experiencing what John Hutchinson describes as a growing "militarisation of charity" (179): increased attention was paid to efficiency and standardisation, be it in terms of procedures or of appearance. Relief societies thus gradually introduced uniforms that resembled those worn 
by soldiers, for example. This evolution can be seen both as part of a wider change towards higher productivity in the economic and social spheres, but also as a response to the accusations of poor coordination previously levelled against relief societies.

In a further attempt to coordinate wartime relief work, the Central Red Cross Committee merged with several other societies to form the British Red Cross Society in 1905. Queen Alexandra was appointed its President and she subsequently called women to form local branches: "I therefore now appeal to all the women of the Empire to assist me in carrying out this great scheme, which is essentially a woman's work, and which is the one and only way in which we can assist our brave and gallant Army and Navy to perform their arduous duties in time of war" (qtd. in Best 99). More specifically, the Queen asked the wife of the Lord Lieutenant in each county to set up county branches of the BRCS. The eighty-six local branches were meant to "become centres of Red Cross activity for their districts" (Red Cross website). Although the call came from the Queen, local branches were thus set up independently from each other; a central committee was however coordinating the work of the organisation as a whole, and leading relationships with other Red Cross societies. A means of keeping branches connected to the centre and with each other therefore had to be found.

The BRCS expanded through the formation of regional branches, and in 1908 it was granted a Royal Charter. By 1914, it had thus been in existence in its current form for almost a decade. Why, then, in an epoch during which the printed press was expanding rapidly, did the British Red Cross Society wait until 1914 to launch its own journal? The demand for a regular publication was present, as underlined in the first issue by the then Chairman of the Executive Committee of the British Red Cross Society E. A. Ridsdale: "The need of an Official Journal devoted to the work of the Society has long been felt, and it is a matter of congratulation that it has at last become possible to meet the wishes of our supporters in this respect" (Red Cross Journal 4; hereafter RCJ). Similar organisations, such as the St John's Ambulance Association, had launched magazines decades before (St John's First Aid was launched in 1894). According to Hutchinson the reason for this delay was the change in leadership that took place within the BRCS in 1912, when eminent surgeon Frederick Treves stepped down and politician E. A. Ridsdale became Chairman of the Executive Committee. Ridsdale had more time to devote to the Red Cross and managed to launch the Journal.

The early issues of the Red Cross Journal cost more than The Times or First Aid, however they numbered thirty pages on average, whereas First Aid only had around 18 pages. The Red Cross Journal described itself as an "illustrated magazine" and the frequency of photographs of prominent members, such as the Chairman of the Council Lord Rothschild, in the first few years of the journal's existence testifies to the desire of making the leading members of the BRCS better 
known. This emphasis on prominent individuals however gave way to a greater focus on Red Cross work during the war, as will be discussed later.

The support of the royal family is also confirmed in the first issue of the Journal, which contains a handwritten message by Queen Alexandra herself. This royal endorsement gave the Red Cross Journal additional prestige and respectability, even though the Queen was not a regular contributor. As noted by Ridsdale in this inaugural issue, news items are expected to be sent by Red Cross members themselves:

Members and well-wishers of our Society can materially help us [...] by supplying interesting local matter for appearance in our columns. As this step has been taken at the instance of numerous keen friends of the Society all over the country, I feel justified, now that we have been able to meet their wishes, in calling upon them to do all in their power to assist us in making this venture a great success. $(1: 1,4)$

Like First Aid, the Red Cross Journal encouraged readers to contribute, stating that "The Editor is desirous that contributors should, so far as possible, have full liberty with their subject to enable them to express their views" $(1: 1,4)$. This participative approach was made possible in part because the Journal tapped into - and contributed to strengthening, as will be shown later - an existing network of people participating in a form of social capital that Peter Grant identifies as "bridging social capital," i.e. "relations with more distant friends, colleagues and associates who share a common aim or principle" (173). In this context, the monthly publication is tangible evidence of the links binding Red Cross members together.

The first issues of the Red Cross Journal, in addition to official news, also contained a significant amount of local news. The latter was originally divided between London and the rest of England (news from other nations is not always featured) and it is diverse in nature, from fêtes to practice drills and fundraisers. A four-page article in June 1914 thus scrutinised a Red Cross practice mobilisation in Devon, while a successful bazaar in Stirling was discussed extensively in January 1914, perhaps in order to inspire other branches to hold similar fundraisers. The news featured depended on the contributions sent by local branches; and the editors did not seem to be struggling to find contents to include since from July 1914 onwards, the call for contributions mentions space constraints and states that "All reports should be as brief as possible" $(1: 7$, n.p.). This pressure on space, already felt before the outbreak of the war, testifies to the success of the journal and the desire among members to contribute. No figures could be found regarding the number of readers and contributors unfortunately, but the fact that the Journal survived the war suggests that it was a viable enterprise, or at least that it was seen as an activity worth investing in.

Within months of its launch, the Red Cross Journal faced dramatic changes, as its parent charity went on to become "the single largest charity operating between 1914 and 1918" (Grant 132). The outbreak of the war in August 1914 
did not lead to immediate changes in the Journal: the publication date being the $15^{\text {th }}$ day of each month, the August issue recorded the outbreak of the war without much more detail. The main mention of the conflict is an acknowledgement of the "patriotic and public spirited action in placing the ground floor of Devonshire House and the Stables and Motor Garage at the disposal of the Society for the conduct of its war work" (256). The publication of a war supplement to the Journal was envisaged, suggesting that the editors did not expect the conflict to warrant coverage in the pages of the journal itself; the scale the war was going to reach was not yet fully appreciated.

War relief was the BRCS's raison d'être and alongside the Order of St John of Jerusalem, it took on significant responsibilities during the conflict. When Red Cross members were so busy caring for wounded soldiers, why, and how, did they continue to publish a monthly journal? As underlined by Jane Potter (13), the publishing industry in the First World War faced greater pressure on contributors, but also material restrictions. The journal published by St Andrew's Ambulance Association thus interrupted publication in September 1916, this decision being described as temporary for the duration of the war $(3: 9,134)$. The Red Cross Journal, on the other hand, was published throughout the war but pressure on space increased as the war went on. From September 1914 onwards the editor requested that submissions be written "on one side of the paper only" (1:9, n.p.). The section on local news also became gradually shorter throughout 1915. At the same time, the number and size of pictures were reduced, and a stricter policy regarding the nature of the photos published was implemented. For example, it was decided that photographs of houses turned into hospitals and their staff, which bore a local interest only, would not be published; group photos were later also dismissed. In practical terms, paper shortages led the journal to shrink from around 30 pages in 1914, to 20-25 pages in 1915, and even further in January 1916 in order to "bring the Red Cross within the half-penny postage rate" $(3: 1,3)$. The main cuts affected advertisements, bringing the total length down to around 12 pages, while the price was also reduced. The Red Cross Journal, like many other publications, thus faced practical challenges due to the war, and it had to adapt.

In addition to affecting the format of the journal, the war also impacted its contents. While no evidence that war supplements were published could be found, a section entitled "Red Cross War Notes" appeared in the Journal from September 1914 onwards, and contributions on war-related matters were explicitly invited: "The Editor will be glad to receive items of any kind likely to be of interest to readers of THE RED CROSS, especially those of recent date relating to work in connection with the War" $(1: 9$, n.p.). Again, it is envisaged that individual members' contributions will form the basis of the information contained in the newspaper; in fact the amount of official news issued by the central committee would also increase exponentially. By the early autumn of 1914, the war was a new development deemed worthy to be reported, but it had not become the focus 
of the Journal yet; rather it was one item of news among others. The Red Cross was also exercising caution: the movements of Red Cross detachments abroad, which could reveal where the British Army's positions were located, were not to be disclosed but the editor reassured his readers, stating that:

[Readers] may, however, rest assured that, just as we are now placing on permanent record, month by month, Major Doughty Wylie's exhaustive and graphic record of the British Red Cross in the Balkan War, so in due time will every detail about our present great enterprise appear in these columns. $(1: 9,293)$

The scale and duration of the war were thus expected to be limited, and the presence of this topic in the pages of the Red Cross publication was anticipated to be limited; war news nevertheless soon became the focal point of the journal.

\section{The Journal: A Communication and Fundraising Tool}

While book publishers were concerned, at the start of the conflict, that book sales would plummet (Potter 12), their fears proved groundless. The war even highlighted the crucial importance magazines and newspapers especially had taken in informing - and influencing - European societies. In Gary Messinger's words, "one of the elements that made the war different was the spread of information through mass communication" (15): the Red Cross Journal participated in this phenomenon, although its engagement with propagandistic discourse is more nuanced than many mainstream periodicals (Messinger 22). The journal was in a situation somewhat akin to that of trench newspapers: the information it conveyed was communicated (and read) by protagonists directly involved in the conflict, and sometimes even posted near the battlefield. As we will show, news from Red Cross work on the Home Front abounded but stories from VADs posted on the Western and Mediterranean fronts gradually increased in number and frequency. Unlike trench newspapers, however, the journal's readership was very varied in terms of backgrounds, roles and war experiences; efforts at making the periodical relevant to all Red Cross supporters and members will also be discussed.

In terms of topics covered during the war, the economy, the increasing scarcity of foodstuffs and the difficulty to find domestic employees frequently featured in the pages of the Red Cross Journal during the first few years of the war especially. This suggests that many of the readers probably belonged to the middle and upper classes, amongst which Red Cross county leaders were initially recruited. The way in which food shortages are reported is telling of the increasing difficulties experienced on the Home Front; such reports are paradoxically used also as an opportunity to reassure readers. Indeed, the situation in enemy countries is also reviewed on occasion, the comparison suggesting that British people 
are faring better than the Germans and Hungarians $(2: 5,100 ; 2: 11,221)$. Such articles encourage readers to persevere in the knowledge that the enemy is also suffering, perhaps even more, and reinforce contemporary propaganda that tended to present the enemy as unable to win the war. Furthermore, articles about ladies' wartime fashion, food prices and the changing roles of women in wartime suggest that the target audience was essentially female. In line with mainstream women's magazines that reminded women of their patriotic duty of "thriftiness, industriousness and pluck" (Grundy Haigh 147), the Journal encouraged gendered patriotic attitudes. For example a November 1915 news item promoted a leaflet on "What not to buy" in wartime, published by the Women's War Economy League (2:11, 223), while another one advertised a shopping bag sold by the Patriotic Shoppers' League to raise funds for the BRCS, and encouraged readers to carry home their lighter purchases themselves (224). Such articles, similar to those found in mainstream women's periodicals, targeted civilians on the Home Front rather than Red Cross members overseas.

While topics of general interest to the Home Front continued to be published after 1915, the focus gradually shifted towards war news, and information relevant to Voluntary Aid Detachments (VAD) in particular. In April $1916(3: 4,42)$ a new section entitled "V.A.D. Notes and News" was launched. Information in this section includes the number of detachments registered in any particular month, but also increasingly obituaries and a roll of honour. Changes in the content of the journal, and to some extent in its target audience, mirror changes in Red Cross operations and its relations with the state. As the need for relief continued and increased during the battles of 1916, VADs became essential to providing care for the sick and wounded. As their number grew, and more of them became posted at home and overseas, their presence in the pages of the Journal also increased. Alongside practical and official information, for example regarding discipline within the Detachments, comments and testimonies by VAD members also appeared. Their focus is sometimes serious, illustrating the dangers and hardships of working near the frontline, sometimes more superficial. A surprising number of comments, and complaints about the female VAD uniforms can be found. For example one woman VAD wrote in April 1917 that:

Surely there is no necessity for the enormous unwieldy brims of both winter and summer hats, or the out-of-the-way ugly shape of the latter also. [...] The gabardine hats for winter wear have deservedly met with nothing but praise; is it too much to hope that some day an equally satisfactory and comfortable summer headgear may be given to us? $(4: 4,47)$

As this quote reveals, although the uniform was widely accepted, concerns were expressed over the apparently unnecessarily unfashionable appearance of the hat, for example. The publication of this and other similar contributions by VAD members testifies to their growing importance in terms of Red Cross 
work and also in terms of the journal's readership. The VAD News section grew so much that it was later divided into Men's and Women's VAD news, the latter often the most detailed. This evolution towards a greater presence of VADs is particularly worth noticing in comparison with the relative decrease in the number of portraits of prominent Red Cross members, which were a frequent feature in the Journal during the years 1914-1916; this change could be interpreted as greater recognition being given to members beyond prominent patrons. This shift is also telling of the growing importance of the figure of the female VAD within British society: alongside munitions workers for example, VAD members became one of Great Britain's "distinctive figures of mobilization" (Purseigle 262).

This increasing presence of VAD news in the journal is telling of a change in the role of the journal as a medium. While its primary function remained to convey information, the communication processes it reflected during the war shifted from top-down communication to a more democratic "horizontal" type of exchange between members. From its inception, the Journal provided information regarding practical matters. In pre-war issues, articles about medical science and First Aid Q\&As can be found, as well as a section entitled "Red Cross Orders," launched in February 1914: "Through the medium of these "Orders' Branches and Detachments will be notified of all changes affecting the Society's work prior to their embodiment in the Society's official forms. Branches and Detachments should therefore read the Orders month by month in connection with all Official Documents published by the Society" $(1: 2,63)$. The information emanated from the central Executive Committee and was, through the medium of the journal, passed on to regional leaders. This article was followed by a list of recently amended paragraphs in Red Cross forms, which replaced previous versions. The Journal was thus initially used to spread information: it was the official medium through which county branch leaders especially could be informed and kept up to date. This was stressed again in the January 1917 issue: "the Official Letter sent by the Central Joint V.A.D. Committee to the Country Directors, [...] contains matter it is vitally important that every Commandant, at least, should be acquainted with" $(4: 1,4)$. The wording in this later article makes it clear that regional leaders were expected to keep up to date with BRCS policies through the channel of the journal. The flow of information is from top to bottom, the journal acting as "a ready means of communication between the Society and its members" $(2: 8,169)$. Throughout the war, information such as lists containing the Society's leaders' names and respective positions, as well as the addresses of the different wartime BRCS Departments, was also regularly published in order for readers to keep up with the evolving structure of the BRCS.

The informational content gradually expanded to include announcements relevant not only to county Commandants, but to all members. This is evidenced in two articles devoted to etiquette in VAD, one of which focuses on when and how to salute $(2: 9,196)$. Changes brought to the uniform were also reported 
$(3: 8,99)$, and reminders regarding the role of VADs or the necessity to comply with fire regulations $(3: 9,118)$ were issued, this content being relevant to an audience larger than county leaders. This expansion of the target audience is also clearly visible in the December 1917 issue, in which the Commandant-in-Chief of the Women's Voluntary Aid Detachments Katharine Furse resigned her position. While her official statement and a response by Arthur Stanley, Chairman of the Central Joint VAD Committee, both of which were previously published in The Times, were re-printed in the Journal, the latter also included a short letter from Katharine Furse to "all [her] V.A.D. friends" $(4: 12,166)$. The journal was thus used to communicate a personal message of thanks to all VAD members, and not only their leaders.

The inclusion of Katharine Furse's message at a time when she no longer held an official position is indicative of the increasingly "horizontal" communication taking place through the Journal, and so are the many contributions from VAD members. Indeed, the war years saw a rise in the amount of content produced by members for other members and the journal gradually became a platform for contributors to share encouragement and practical tips, albeit in a space controlled by the BRCS. Examples of practical advice shared by members include a list of suggested menus for a Red Cross hospital put together by the East Lancashire Foodstuffs Advisory Board, for use by other Red Cross hospitals $(4: 4,49)$. In June 1917 another reader shared a table to help count how many days a patient had been in hospital (81), while from June 1918 onwards a new section advertised used VAD uniforms needed or for sale (67). The war thus turned the Red Cross Journal into a means of communication not only from the central committee to county leaders, but between all members. This evolution, as will be discussed later, helped foster a sense of cohesion between members involved in increasingly diversified tasks.

Alongside a shift towards VAD news, increasing attention was also paid to a key aspect of the BRCS's war work: fundraising. The Journal regularly reported on fundraising activities organised by, or for the benefit of, the Society. In cities and in the countryside, the ladies who had responded to the Queen's appeal and set up county branches of the Society were often actively engaged in a number of philanthropic activities (Bush 30), and they could potentially tap into an existing network of patrons. During the war, fundraising activities however expanded to appeal to the British population as a whole. Regular updates on money raised through events such as "Our Day" collections, Christie's auction sales and one-off donations were published, showcasing the support the BRCS was enjoying among the British public, but also generous patrons abroad. In particular, the support of foreign Red Cross societies such as the American, Canadian and Australian organisations was acknowledged.

In addition to reporting on successful fundraising campaigns, the Red Cross Journal itself became a means to raise awareness and funds. This function became 
increasingly visible throughout the war years, with the frequent publication of appeals for donations in the pages of the journal. For example in July 1915, the journal featured an appeal for the Motor Ambulance Fund, "the most urgent of all funds," accompanied by an image of a wounded soldier with a bandaged head and arm, still looking very manly and whole, and the words "Help Him"” (2:7, n.p.). This evolution suggests that the periodical that had started as a means of communication between the central committee and local branches was increasingly aimed at an audience beyond active members and including patrons. Beyond the use of the journal as a medium to organise and publicise fundraising campaigns, the journal can be seen as a fundraising tool in itself. In 1915 the call to readers is gentle: the editor states in January that "we may express the hope that Red Cross members will make the Red Cross known to others. [...] The entire proceeds of the Red Cross go to the British Red Cross Society [...] every subscription to the Red Cross is a help to the Society" $(2: 1,12)$. In 1916, this function of the journal is more clearly articulated: "Subscribers will be gratified to know that in taking in the Red Cross they are assisting to make a by no means insignificant contribution to the fund of the British Red Cross Society" $(3: 12,154)$. In 1917 the call becomes more pressing: "may we urge each of our subscribers to do us two favours in 1917? One is to find a new subscriber. The other, to send us reports of their work [...] Everyone who subscribes to the Red Cross is fairly entitled to consider himself or herself a donor to the funds of the British Red Cross Society, as the profits earned by this journal are received, without deduction, by the Society" $(4: 1,5)$. Readers are thus regularly asked to encourage others to take out a subscription in order to raise additional funds for the work of the BRCS. This stress put on the journal as a means to raise awareness and funds did not disappear with the end of the war, with another pressing appeal published in 1921 (8:1, 2). The repetition of such appeals suggests that readership was expanding and that the journal was regarded as a viable source of income for its parent society.

The inclusion of news from other national Red Cross societies, for example articles reporting the work of the Swedish $(3: 3,32)$ or the Russian $(3: 3,31)$ Red Cross societies, besides reveals a growing awareness of belonging to an international movement, and perhaps also an increasing collaboration between different societies. The Journal also included updates on the Eastern Front and even more, the Mediterranean area, giving it an increasingly global outlook, a far cry from the early 1914 focus on Great Britain. News from local county branches continued to be included, albeit in a very condensed format, annual reports being often printed in a smaller font than feature articles. Reprints of articles published in the Nursing Times, the Lancet and the British Medical Journal also featured, showing a growing connectedness with other medical and nursing professional organisations. 


\section{Reflecting the Expanding Work of the Red Cross and Changing Views on War}

The Journal was used as a communication and fundraising tool; it also gives an insight into how Red Cross members viewed the war and their organisation's involvement in it. Grant and Meyer underline the control exerted by state authorities over voluntary organisations, and the fact that the Great War saw relief organisations firmly side along their national governments. The Red Cross Journal is not a source that has been studied before in order to evaluate the evolution of patriotic discourse within the British Red Cross Society; it will now be analysed in this light.

The war is presented as a test for the BRCS to deliver relief on a largescale, but also for the British population to live up to the challenge of providing adequate relief. The September 1914 Journal - the first one to address the war on a significant level - contains a reprint of a letter written by BRCS officials to The Times editor, in which they state that helping the wounded is a national duty: "Let it never be said that, in the pressure and confusion of these unhappy times, the wounded sailor or soldier went lacking or was, for the moment, forgotten. [...] The least we can do is to afford him such assistance in his distress as will make him feel that his nation is not ungrateful" $(1: 9,292)$. Supporting the BRCS is presented as the way for the public to care for combatants and beyond, do their patriotic duty. This letter, published early in the war, inscribes the work of the BRCS within a specific national context. The frequent use of the possessive pronoun "our [soldiers]" reinforces this sense of belonging to a national community: the funds raised from among British donors are aimed to help British soldiers. Despite this surge of patriotism at the start of the war and in articles related to fundraising especially, the Red Cross Journal is largely void of patriotic declarations during the first years of the war. Newspapers such as The Times were openly demonising the enemy, for example reporting the destruction of the Reims cathedral in 1914 in those terms: "We ought to have foreseen this crowning atrocity, for Reims is hallowed ground to the modern Attila and to every Hun" (Times 21.09.1914, 9). The Red Cross Journal rarely criticised the enemy, probably due to the BRCS's institutional affiliation to the neutral International Committee of the Red Cross. A note published in November 1914 explained this decision to refrain from reporting criticism against the German Red Cross: "We have not, so far, discussed in these columns the question of alleged abuses of the Red Cross by the Germans; neither is it our intention to do so now. But a time will come when all these matters will have to be gone into fully" $(1: 11,367)$.

In the first year of the war, the concerns expressed in the Journal focussed on the treatment of sick and wounded soldiers. Even events that attracted widespread international condemnation, such as the burning of Reims cathedral and the execution of nurse Edith Cavell, were hardly mentioned, showing a reluctance to engage in the politics of war. For example, the article that announced the death of Cavell stresses the universal condemnation of this action, rather than 
examining the possible implications for Red Cross personnel: "We share to the full the outraged feelings expressed in all countries of the world which still have any claim to be called civilized; and we sincerely trust the day will come when those responsible may themselves stand in sore need of the mercy they denied to our devoted countrywoman" $(2: 11,226)$. The shared national origin of British Red Cross volunteers and nurse Edith Cavell is hinted at but not dwelt upon. Criticism against the enemy appeared mainly in reprints of articles published elsewhere; these are rather few but they nevertheless gave the Journal the opportunity to implicitly denounce the enemy. Thus, the October 1914 issue featured the testimony of a doctor whose house in Louvain, although it bore the Red Cross flag, was pillaged by German troops $(1: 10,333)$, while the outrage caused by the German army apparently refusing to free British surgeons taken prisoners was reported through the eyes of the International Red Cross Committee rather than that of the BRCS $(2: 1,4)$.

Contributors reacted most strongly to breaches directly affecting war relief; the use of a hospital ship for "ordinary war purposes" is thus described as "one of the greatest crimes committed by the Germans" $(2: 5,124)$. The Journal seems especially concerned with "the far-reaching consequences of sowing confusion in connection with the succour of wounded men": the main source of worries is thus not national matters, but issues specific to the missions of the BRCS. Likewise, a May 1916 piece on the treatment - or lack thereof - of ill Allied prisoners who were left to die of typhus in the Wittenberg camp, denounced the "cruelty" shown by the German doctor in charge, who failed to care for the diseased prisoners and therefore exposed healthy prisoners to the bacteria $(3: 5,55)$. This article, like others on the use of poisonous gas for example, gives the Journal an opportunity to assert the moral superiority of British doctors and by extension, of the British people over the Germans: "Our chief objective in referring to the matter is to call attention to an act of cowardice which would be impossible in this country" $(3: 5,55)$.

The year 1918 showed a significant departure from the Journal's previously restrained discourse on the enemy's practices but also on their moral values. Criticism increased and the Journal began to openly engage with common propaganda tropes, especially "the stereotype $[\ldots]$ of Teutonic brutality and ruthless inhumanity" (Taylor 179). This rhetoric is particularly visible in relation to the use of poisonous gas $(5: 3,34)$ and it is in line with the International Committee of the Red Cross' condemnation of chemical weapons. As the summer counteroffensive started, explicit condemnation of German actions can be found, for instance in an article entitled "Outrages and Attitude," published in June 1918:

The cruel outrages perpetrated on the Red Cross by the Germans - the sinking of hospital ships, the deliberate bombing of hospitals, the atrocious treatment of prisoners, and the misuse of the emblem itself, provoke a righteous anger which is more 
than justifiable. [...] The deliberate bombing of the great hospital at Etaples [sic] is the worst, but only one, of many similar atrocities. The destruction of human life which can never be made good and the grief and anxiety caused to the relatives of the 300 victims - indeed, to the relatives of all who were known to be working in Etaples [sic] - compel us to discuss what our attitude should be towards those whose treachery and brutality have brought disgrace on the Red Cross movement. [...] It is probable that even in bombing a great hospital they work on a plan which seems to their diseased ideas of right and wrong to be justifiable. $(5: 6,65-66)$

The accumulation of crimes is presented as having forced the Journal to stand up against the breaches of the Geneva conventions perpetrated by the Germans. The terms used ("cruel outrages," "deliberate bombing," "atrocious") are consistent with contemporary propagandistic rhetoric and emphasise the savagery of the enemy, which stands in stark contrast with the "righteous anger" felt by Red Cross members. One side is associated with justice, the other with evil. The public condemnation the Journal finds itself "compelled" to issue does not appear to be motivated by attacks against British assets, but against the humanitarian principles it stands for. To the physical violence perpetrated are added degraded values ("treachery," "brutality") and a warped perception of right and wrong, which reinforce the idea that the enemy cannot be counted amongst the civilised nations of the world, a theme often found in propaganda. The impact of such practices and attitudes on the reputation of the Red Cross movement is presented as a significant source of concern. The use of the German Red Cross as "an engine of war, and part of the Army itself" is strongly criticised, suggesting that the BRCS did not see itself as serving its own national cause in the same way, but rather serving ethical principles transcending national boundaries.

The discrepancy observed between the work of the German Red Cross and the values of the international Red Cross movement prompted the Journal to wonder what the relationships with the German Red Cross would be once the war had come to an end:

The Red Cross emblem has been stained by the Germans, so that as a military signal on which soldiers can rely it has been made suspect as it never was before. [...] We may owe it to the interests of the Red Cross movement all over the world to show, by a period of abstention from co-operation with those who have done this injury, that their betrayal requires purging in the interests of the emblem which has been besmirched by their vileness. $(5: 6,66)$

Rather than the German army, it is the German Red Cross that is criticised, accused of failing to uphold humanitarian principles and by association staining the reputation of other societies. In contrast, the Journal portrays the BRCS as an organisation defending principles that are above national preoccupations. This focus on humanitarian concerns does not contradict Meyer's and Grant's analyses; 
if in practice the BRCS (through the Joint War Committee) became increasingly controlled by military authorities, the study of the Red Cross Journal suggests that on an ideological level it cultivated the image of an independent organisation upholding humanitarian principles rather than patriotic ideas. A 1915 article made this hierarchy clear: "Many V.A.D. members have found themselves confronted, since the Government's call for assistance in military hospitals, with a question of divided allegiance. Their country asks for volunteers, but they are already pledged to their local Commandants. What is their duty? The answer is clear. They must fulfil their contracts to the Commandants" $(2: 7,142)$. In the eyes of the BRCS, service to the Red Cross took precedence and BRCS members were expected to honour their commitment to the Red Cross. Nevertheless, this analysis has shown that as the war went on, the BRCS increasingly adopted a patriotic discourse that helped justify Britain's as well as its own continuing involvement in the conflict.

In addition to conveying the BRCS's changing views on the war, the Red Cross Journal also reflected the expanding work of the BRCS. At first, the disruption to the normal workings of the Red Cross showed through the inclusion of articles explaining the changed structure of the Society, with the names of individual members responsible for particular areas, such as auxiliary home hospitals, convalescent hospitals, hospital and ambulance ships (1:9, 295). In October 1914 two pages were devoted to clarifying the role of the BRCS in the war (326-327), in answer to the "disappointment" and even "complaints" (326) expressed by members regarding how they could contribute to the war effort. The Red Cross, through its journal, tried to maintain discipline and harmony amongst its keen volunteers, in order to prevent a repetition of the lack of coordination criticised in the South African War. In contrast, the efficiency of the organisation in the new war was highlighted, for example in a report by Sir Frederick Treves on the work of the Red Cross in northern France $(2: 1,17)$. His reputation as previous Chairman of the Executive Committee and as an eminent surgeon, but also his experience in the Boer War, would have made his report a particularly notable contribution to the Journal. In this article he underlines the resources "disposed in the most perfect order" in the Boulogne store, itself described as "a model of efficiency." The organisation's adaptability was also celebrated, the July 1915 review of one year of war work $(2: 7,148)$ telling of speedy changes, for instance from "insufficient and obsolete" transport methods at the start of the war to efficient motor ambulances.

If the care and treatment of the sick and wounded remained the focus of the BRCS, with many articles devoted to hospitals, convalescent homes, motor ambulances, hospital ships and trains, greater emphasis was gradually put on the society's new and diversified missions. In this respect the Journal was used to make these activities known and to call for help. Two of these new activities are the search for missing soldiers and the provision for prisoners of war. Responding to enquiries related to the wounded and the prisoners is described as "a definite 
part of the Society's operations" $(2: 1,2)$ as early as January 1915. An April 1915 article follows an imaginary woman searching for information about her missing husband and three sons $(2: 4,82)$; this article thus highlights the usefulness of the Inquiry Department, but also the work of "pure mercy" carried out by the BRCS in giving relatives answers and sometimes enabling them to contact the soldiers. The fast-increasing volume of enquiries received was repeatedly emphasised, and regular updates on the number of queries received were also published; for example, readers were informed that 8,702 enquiries were received by the Missing and Wounded Department, and 11,838 reports collected by researchers in August $1916(3: 9,124)$. In addition to quantitative surveys, letters from prisoners of war expressing their gratitude for the parcels sent through the BRCS were also published, showing the value of this activity $(3: 9,132)$.

Another two new activities regularly discussed in the Journal are the setting up of the Star and Garter home from 1916 onwards, and the creation of a war library (first mentioned in July 1915 (144)). The BRCS collected books to send to patients in hospitals in the UK and abroad; between 1 May and 8 August 1916, 64,000 books were sent to UK hospitals and 118,000 abroad $(3: 9,110)$. This led to frequent appeals for book donations; this scheme, like the Star and Garter, would continue beyond the end of the war, as did work among prisoners of war, for whom new difficulties arose after the Armistice. According to the Journal many prisoners were released or escaped without food or clothing, and were left to make their way home through Germany and France, making it urgent for the Red Cross to intervene $(5: 12,144-145)$.

The difficulty of demobilisation, and the desire to see some of the Society's work continue was also expressed. The introduction of a scheme to use motor ambulances for the transport of civilians $(6: 8,91)$ illustrates not only the material demobilisation, but the energies and goodwill that remained and which were channelled into other activities. The immediate aftermath of the war thus saw a further diversification in the missions of the Red Cross, this time to encompass support for civilians, for example in promoting Infant and Child welfare $(6: 4,39)$. Trying to build on the momentum and reputation acquired during the war, the BRCS became involved in caring for civilians, this time under the supervision of the Ministry of Health $(6: 8,91)$.

The diversification upon which the British Red Cross Society embarked during the First World War and the scale of its mobilisation in terms of resources and people thus show in the pages of the Journal. As a result of this increased membership and of diversification in terms of members' backgrounds but also of their war work, the Journal was used to foster a sense of cohesion within the Society. Articles recounting the history of the Red Cross movement, and of the BRCS especially, stress the common values and vision members were expected to share. A first overview of the history of the British Red Cross was published in early 1914, while another account published in 1917 suggests that the readership 
had expanded between these two dates and the origins of those shared principles and concerns should be stressed again. In addition to historical overviews, more humorous contributions by women VAD also featured, including the story of a kitchen disaster just before an inspection in September 1917 (4:9, 119). Such light-hearted articles provided relief from otherwise serious war-related matters; they were also an opportunity for readers to share in the daily life of fellow BRCS members. In May 1917 a letter from a VAD member highlighted the importance of mutual encouragement, a motivational function that could be fulfilled through the medium of the Journal:

The Commandant-in-Chief sends us the following characteristic letter from a wellknown V.A.D. in charge of a Red Cross Hostel in France, whose buoyant spirit and abounding courage will be helpful to those of lesser faith. Perhaps, in some dark moment of discouragement, its loyal and enthusiastic phrasing may be recalled to support a fellow V.A.D.'s halting steps over a thorny place. $(4: 5,61)$

The hope that this contribution would help lift the spirits of other members is explicitly stated, and the positive outlook on the sometimes difficult situations described in such articles is probably the reason why they were chosen for publication.

The Red Cross Journal was thus a medium for BRCS members to encourage one another and more generally, to foster a sense of community, regardless of the contributors' and readers' geographical posting and of the nature of their war work. The outbreak of the war saw a decrease in local news, the aim shifting to maintaining links between the Home Front and Red Cross units abroad $(2: 1,12)$. The journal bridged the gap between BRCS members abroad and at home, as is made clear in a 1916 "Tour of Inspection in France" reported in the Journal (3:8, 99-100): "VAD members may like to hear what some of their friends are doing under the Joint Committee in France. [...] The work in the hospitals is, of course, the same as at home, and the glamour of being 'abroad' is quite counterbalanced by the fact that for six months at a time the members are out of reach of their relatives and friends" (100). The comparison between work in Great Britain and overseas, and the downplaying of any differences, serves to validate the work done on the Home Front but it also fosters a sense of common service, regardless of the place. The journal thus also functioned as a means to promote a sense of unity and of belonging amongst members engaged in a variety of tasks in different locations. This desire to foster cohesion within the BRCS was reinforced by the outbreak of the war; however it was also, we argue, an answer to the devolved structure of the BRCS. As county branches were set up independently from each other in response to Queen Alexandra's 1905 appeal, the Journal served as a means of keeping branches connected to the centre and with each other. Thus, if the Red Cross Journal gives an insight into the Society's perception of the war and of its 
own role in the conflict, it also fulfilled a number of functions that went beyond its informational dimension.

\section{Conclusion}

The Red Cross Journal was launched in response to a need for a communication tool, initially for the central Executive Committee to disseminate information. However it took different functions in the course of the war, and its role and contents reflected changes within the work of the British Red Cross Society as it adapted to the wartime situation. The wide range of activities in which the BRCS was involved - from providing relief to wounded soldiers to finding missing servicemen and supplying food to prisoners of war - as well as the extent to which this charity mobilised its members and the general public are made clear in the pages of the Journal.

The Journal did not only report on the work carried out by the Red Cross, but it also served practical purposes in the areas of training, awareness-raising, social cohesion and fundraising. These multiple functions distinguish it from mainstream periodicals and partly account for its survival: the fact that it did not miss a single month during the war and carried on after peace suggests that it was perceived by both readers and headquarters as a useful enterprise. The Journal, like the British Red Cross Society as a whole, underwent significant changes throughout the conflict and its target audience expanded as shown in the type of contributions that started to be published (such as articles by and for VADs, notes of a practical nature and fundraising appeals).

This analysis of the Red Cross Journal has also shed light on the complex situation the BRCS found itself in as it sought to uphold neutral humanitarian principles but recruited members and donors largely amongst the British public. This article has shown that the loyalty expected from members, if it sometimes seems to supersede national allegiance, does not contradict patriotic sentiments but neither does it systematically adopt the propagandistic motifs seen in more broad-reaching publications. The Journal besides shows little engagement with the Order of St John of Jerusalem, with which the British Red Cross Society joined forces in October 1914 to form the Joint War Committee. The aim of this joint committee was to coordinate war relief and avoid a repetition of the South African chaos. St John's is however rarely mentioned in the Journal, suggesting that the British Red Cross kept a distinct identity although a large part of its work was conducted under the auspices of the Joint War Committee. Hutchinson goes as far as stating that the BRCS and St John's were "open rivals" (253) that were "forced into a partnership [...] for the duration of the war" (255). No open criticism of this partner organisation can be found in the Journal, however, although it is true that the two charities parted ways again at the end of the war. This separation, 
which was complicated by the amount of funds raised together, shows that despite the similarity in their wartime work, and the British Red Cross Society starting to emulate St John's Ambulance Association in working among civilians in peacetime following the Great War, the sense of a distinctive identity amongst Red Cross members, which had been fuelled by wartime work and encouraged in the pages of the Journal, remained strong.

\section{References}

The Red Cross Journal issues that form the basis for this article (1914-1921) were consulted at the British Red Cross Society Museum and Archives (London), the British Library (London) and the Bodleian Library (Oxford).

Anon. 1914. "Queen Alexandra and Red Cross Work: Appeal to the Nation." The Times (3 August).

Best, S.H. 1938. The Story of the British Red Cross. London: Cassell and Company. Bush, Julia. 2000. Edwardian Ladies and Imperial Power. London: Leicester University Press.

Carrington, Beryl. 1995. Care in Crisis: Hertforshire BRC 1907-1994. Hertfordshire: Baron Birch for Quotes Ltd.

Fuller, J. G. 1991. Troop Morale and Popular Culture in the British and Dominion Armies 1914-1918. Oxford: Clarendon Press.

Grant, Peter. 2014. Philanthropy and Voluntary Action in the First World War: Mobilizing Charity. Abingdon: Routledge.

Grundy Haigh, Emma. 2016. "The Adventures of the Lady Typist: Redefining the Heroic in Early Twentieth-Century Women's Spy Fiction." Middlebrow and Gender, 1890-1945. Ed. Christoph Ehland and Cornelia Waechter. Leiden: Kroninklijke Brill. 138-161.

Hutchinson, John. 1996. Champions of Charity. Oxford: Westview Press.

Little, Branden. 2014. "An explosion of new endeavours: global humanitarian responses to industrialized warfare in the First World War era." Journal of the International Society for First World War Studies 5. 1: 1-28.

Meyer, Jessica. 2015. "Neutral Caregivers or Military Support? The British Red Cross, the Friends' Ambulance Unit, and the Problems of Voluntary Medical Aid in Wartime." War and Society. 34. 2: 105-120.

Messinger, Gary. 2011. Battle for the Mind: War and Peace in the Era of Mass Communication. Boston: University of Massachusetts.

Potter, Jane. 2007. "For Country, Conscience and Commerce: Publishers and Publishing, 1914-1918." Publishing in the First World War: Essays in Book History. Ed. Mary Hammond and Shafquat Towheed. Basingstoke: Palgrave Macmillan. 11-26. 
Purseigle, Pierre. 2012. "Home fronts: the mobilisation of resources for total war." The Cambridge History of War. Vol. IV: War and the Modern World. Ed. Roger Chickering, Dennis Showalter, and Hans van de Ven. Cambridge; Cambridge University Press. 257-284.

Red Cross website, "The founding of the British Red Cross." http://www.redcross. org.uk/About-us/Who-we-are/Museum-and-archives/Historical-factsheets/ The-founding-of-the-British-Red-Cross

Royal Commission on South African Hospitals. 1901. Royal Commission appointed to consider and report upon the care and treatment of the sick and wounded during the South African war. HMSO.

Taylor, Philip. 2003. Munitions of the Mind: A History of Propaganda from the Ancient World to the Present Era. Manchester: Manchester University Press. Williams, Kevin. 2009. Read All About It!: A History of the British Newspaper. Abingdon: Routledge. 
Sara Prieto

(iD https://orcid.org/0000-0002-0453-7951

University of Alicante

\title{
"War song of America": The Vigilantes and American Propagandistic Poetry of the First World War
}

\begin{abstract}
When the United States entered the First World War in April 1917, the Committee of Public Information (CPI) organised several branches of propaganda to advertise and promote the war in hundreds of magazines and newspapers nationwide. One of these organisations was the group of writers known as "the Vigilantes." This essay examines Fifes and Drums: A Collection of Poems of America at War (1917), published by the Vigilantes a few months after the American declaration of war. The discussion frames the context under which the Vigilantes conceived their poems as well as the main strategies that they employed to poetically portray the role that the United States was to play in the conflict.
\end{abstract}

On 2 April 1917 President Thomas Woodrow Wilson addressed the United States Congress to ask his fellow congressmen to declare war on Germany and support an American intervention in Europe. The American government had decided to mobilise their men to intervene in a war that many Americans perceived as alien; this would be the first time in history that the United States would send troops to fight a war away from American soil. For this purpose, President Wilson and the American government had to convince their people of the need to support what many perceived as a merely European affair. The American government expected Americans to be willing to sacrifice their lives for a great moral cause, but this would not be an easy task. Before the declaration of war, the United States was deeply polarised regarding a potential intervention in Europe. Once the US Congress supported President Wilson's petition, the American government faced two main challenges: on the one hand, they had to fully convince the American public of "the rightness of the cause" (St. John III 2009, 150); on the other hand, they needed American citizens to "embrace sacrifice to support the war" (St. John III 2009, 150).

The American government designed several methods to convince the public opinion about the crucial role that the United States would play in the European 
conflict. The administration initiated a propaganda campaign that imitated the strategies that the British had followed at the beginning of the war. At the request of the Prime Minister, Herbert H. Asquith, Charles Masterman had established in September 1914 the War Propaganda Bureau at Wellington House, which "rapidly developed into the most active of all the propaganda departments, arranging for the production and overseas dissemination of books, pamphlets and periodicals as well as photographs, lantern slides and picture postcards" (Taylor 877). The British had soon realised that words would become an essential weapon in this war; they created different propaganda campaigns to support the troops, keep up the morale in the Home Front, and encourage the younger generation to embrace the struggle. To this end, Wellington House shaped multiple campaigns that Masterman expected to be of the "highest literary quality, academic in tone and scholarly in content, rather than simply propagandistic diatribes" (Sanders and Taylor 107). Masterman even decided to create a special branch of Wellington House in the United States which would deal solely with British propaganda in America, appointing the Canadian novelist Gilbert Parker as the head of the American department (Sanders and Taylor 167-168.). At the beginning, the main goal of propaganda in America was to maintain the appearance of "benevolent neutrality" (Buitenhuis 17) on the part of the United States, and to safeguard American loans, shipping of food, and war material to support the Allies. This initial neutral stance would gradually evolve into a more aggressive policy in which the American press would call more or less subtly for an American intervention in the European war.

\section{The CPI}

When the United States finally declared war on Germany in April 1917, the American government was therefore widely familiar with some of the propaganda techniques that could shift public opinion in favour of the war. On 13 April 1917, only a week after the declaration of war, President Woodrow Wilson appointed the Committee on Public Information (CPI). The CPI was created to disseminate facts about the war, to coordinate propaganda material, and to serve as the institutional liaison with newspapers. George Creel, an investigative journalist, became the person in charge of the propaganda campaign in the United States. Creel was mostly concerned with the "creation of thought" (Axelrod 81), so he did not initially establish any institutional censorship. He conceived the war as "the fight for the minds of men" (Creel 3; original emphasis) and for this purpose the CPI initiated a campaign "to spread the word of America's war aims and appeal for public support" (Creel in St. John III 2009, 40), and to educate Americans and others in the "gospel of Wilsonian democracy" (Axelrod 82). The image that Creel wished to create was that of a country that should come "to the rescue of civilization" (Mock and Larson 5). 
George Creel conceived the conflict as "the world's greatest adventure in advertising [...] with the war as the product to be merchandised" (Harries and Harries 165). The thousands of miles that separate Europe and America turned the war into "a virtual phenomenon" for most Americans (Matthews 217). The American view of the war relied on the war materials published in newspapers, magazines, posters, pamphlets, and other forms of information such as rallies or public speeches. In a way, "American writing of the war was the war" (Matthews 217). Creel took advantage of this physical distance between America and the European continent and controlled almost the totality of the incoming information. Yet, he also wanted to "inject positive thoughts into the nation's psyche" (Harries and Harries 168). He structured this positive discourse around the definition of America as a democratic world leader (Jeffrey 221). The war was presented as a "holy war" (Quinn 178), "a life-and-death struggle against the forces of darkness" (Ross 226). The government needed to persuade the different political, intellectual, and economic lobbies about the rightness of America's war cause, and also needed to inspire American soldiers in their fight for democracy.

Propaganda naturally became a crucial tool to achieve these objectives. As Alan Axelrod has explained in Selling the Great War: The Making of American Propaganda (2009), propaganda is "the message - the picture of reality - the state wants the people to receive and believe [...]. Propaganda is not necessarily untrue, but it has little to do with people thinking for themselves" (49). Creel created a propaganda network made up of thousands of intellectuals who engaged as public speakers and writers who advertised and promoted the war in hundreds of magazines and newspapers nationwide; he organised rallies, speeches, and published the Official Bulletin of war news. True facts were moulded and manipulated to be presented as evidence to American people. These strategies, Creel thought, would be sufficient to weigh in and persuade Americans to "make the decisions the state wanted them to make" (40). The government and the CPI expected American civilians to positively embrace the declaration of war and to be willing to sacrifice their lives and their economic privileges for the great cause.

The CPI set up hundreds of lectures, designed a vast number of posters to be distributed throughout the United States, produced film documentaries, organised war exhibitions, and created advertising photographs, postcards, and cartoons to support the American intervention. Inspired by Charles Masterman's work at Wellington House, who had organized a conference with more than twenty British writers who later supported the war by signing the Authors' Manifesto, ${ }^{1}$ George Creel assembled all American writers willing to support the war into a team. The CPI "gathered together the leading novelists, essayists, and publicists of the land, and these men and women, without payment, worked faithfully in the production of brilliant, comprehensive articles" (Creel 8). The News Division under the CPI sent weekly war reports to twelve thousand daily newspapers, which resulted in about six thousand columns of war stories encouraged by the CPI (St. John III 2009, 150). 


\section{The Vigilantes}

The Vigilantes, who had been co-founded by German-American poet Herman Hagerdon in 1916, are one of the literary groups that emerged under these circumstances. At the beginning, the group was "a military-style organization of intellectuals and writers dedicated to propagate American interventionism abroad" (Piep 178). It was not until a few weeks before Wilson's declaration of war that they became an officially established group. In keep with the policies of the CPI, the Wheeler Syndicate and the American Press Association managed this group of writers and "recruited prominent authors, artists, and editors to produce antiGerman propaganda that would extol democratic beliefs, motivate the populace, inspire patriotism, and encourage Allied involvement in the war" (Underhill 71). The Vigilantes called themselves "The Minute Men of the Pen" and volunteered to promote the American war effort for free as they agreed to write essays or editorials of around 1,000 words every month (Van Wienen 2002, 29; Underhill 73). The group defined itself as "a non-partisan organization of authors, artists and others" (Rosebault ii) and it included authors such as Gertrude Atherton, Gelett Burgess, Amelia Josephine Burr, or Irvin S. Cobb. ${ }^{2}$ Their objectives were: a) "To arouse the country to a realization of the importance of the problems confronting the American people"; b) "To awaken and cultivate in the youth of the country a sense of public service and an intelligent interest in citizenship and national problems"; c) "To work vigorously for preparedness; mental, moral and physical" (Rosebault ii).

Creel considered that Americans needed "role models, both fictional and real" (Quinn 173), and the Vigilantes was one of the many resources that he employed to advertise the war in the United States. The Vigilantes published two books in 1917: the first one, For France, was an anthology of prose and poetry that appeared in April; the second one, a book of poems entitled Fifes and Drums: A Collection of Poems of America at War, was published in June and included more than sixty patriotic poems conceived as a "striking record of the emotional reactions of the American people during the fortnight and the six weeks following the declaration of war" (Rosebault v). By the end of the war, more than 300 writers had enrolled in the Vigilantes, who had "formed to feed patriotic writing under strict editorial guidelines" (Whalan 2014).

The Vigilantes became one of the most active and productive groups in the sphere of literature related to the First World War in America. Despite their significance, few critical studies have discussed the role that the group played in the construction of the specifically American discourse during the First World War and its impact on the portrayal of the American experience of the war. Led by Paul Fussell's influential and controversial The Great War and Modern Memory (1975), traditional critical studies on the English-speaking literature of the First World War have evolved around the anti-war poetry produced by British soldiers 
on their mutilating and traumatic experiences in the trenches. This trend has been widely contested and positively reversed in the last decades, as some of the volumes on the poetry of the First World War published in the last years prove. ${ }^{3}$ Nevertheless, critical studies on American poetry during the First World War are still scarce, especially those devoted to the poetry of those civilians who wrote about the war without participating in actual combat.

There are two major studies about American poetry of the First World War, Partisans and Poets: The Political Work of American Poets in the Great War (1997) and Rendezvous with Death: American Poems of the Great War (2002), both published by Mark Van Wienen, which briefly explore the work of the Vigilantes and the nature of the texts they produced. The latter is presented as the first collection of poetry "representing the wide range of American poems published in response to the Great War" (Van Wienen 2002, 1). His anthology includes more than a hundred poems which stand as an example of how current criticism has contested the traditional canon of the poetry of the First World War. Van Wienen moves beyond "the strictures of literary value [...] formulated in the 1910s by the modernists and the conventions that continue to inform literary judgments [...] in the present" (3), while at the same time moves away from "the cult of the soldier-poet" (7). ${ }^{4}$ Van Wienen acknowledges the powerful role that this wide variety of poems played in the America of the time; the authors who produced them perceived the poems "as weapons: literally, as tools of war that might bring U.S. citizens to kill their German counterparts" (1). Van Wienen also includes, in "Part 5, 1917" of Rendezvouz with Death, a brief reference to the Vigilantes; he establishes that organisations such as this were

crucial for Americans to believe that the ideals prompting intervention were distinctive from, and superior to, the European powers' motivations in 1914; that American citizens felt they had freely chosen their roles in the war effort and the sacrifices entailed by those; that patriotic American poets [...] gave expression not to a partisan position but to a transcendent national purpose. (153)

In spite of Van Wienen's interest in moving beyond "the strictures of literary value," his anthology of American poetry of the First World War does not include any of the poems published in Fifes and Drums. Moreover, he fails to critically discuss the role of the poems written by the Vigilantes beyond the short explanation provided above these lines. ${ }^{5}$ In 2017, Lonnie E. Underhill published an article on vigilante Hamlin Garland, arguing that "the patriotic work of the Vigilantes, and in particular the contributions of author Hamlin Garland [...] deserve further recognition" (71). Nevertheless, Underhill's focus is directed at the role of a specific author; he fails to map the common structure and ideology underlying the collection of poems gathered together in Fifes and Drums.

The patriotic and propagandistic role that these poems played is widely acknowledged; notwithstanding, no comprehensive study that discusses the poems 
in Fifes and Drums in their relation to the American propagandistic discourse of the First World War has been published yet. This essay seeks to fill in this gap as well as to enlarge the critical discussion around the Vigilantes through the examination of the strategies that this group of authors employed to create American propagandistic poetry with a specific purpose in mind: presenting the United States as a safe keeper of democratic ideals. The main question under discussion is to what extent Fifes and Drums contributed to the dissemination of a specific ideology that portrayed the American nation as a chosen land and as the cradle of modern civilisation and modern democracy. For this purpose, I shall examine the rhetorical and stylistic strategies that the poets employed to perpetuate this patriotic discourse, and to what extent these are in keep with the larger propagandistic campaign that was created to mobilise the American public opinion in favour of the war. In doing so, I shall amplify the literary map of the First World War and establish new connections within a war tradition - that of civilians contributing to the war effort through their writing about the war from the rear-guard - that radically differs from the literary construction of the war portrayed by the more canonical American authors of the First World War such as John Dos Passos, John Reed, E. E. Cummings, or Ernest Hemingway, as well as from the work of the war poets of different warring nations such as the British Wilfred Owen or Siegfried Sassoon, or the French Guillaume Apollinaire. ${ }^{6}$

The Vigilantes thought that they needed to convince the American people about the need to fight the war and, at the same time, they needed to explain the specific nature of this war. In my discussion of how Fifes and Drums portrayed a specific vision of the war, three main ideas need consideration: firstly, the name that this group of writers chose to define themselves; secondly, the main strategies they employed in their poems to promote this specific ideology; and thirdly, the underlying relationship between their chosen topics and specific founding values of the American republic such as freedom or justice.

Vigilantes is a name with strong resonances in the American mind-set. The term has been historically associated with frontier culture. During the Western expansion of the $19^{\text {th }}$ century, upon the explorers' and settlers' arrival in new territories, vigilante committees were created to play the role of the official sheriff or person of law that invigilated that the newly created communities of these territories respected the laws of the Constitution. The committees were made up of civilians who created their own system of justice and usually took the law in their own hands. ${ }^{7}$

Although the ideals of the Vigilantes during the First World War did not promote lynching or radical violence against other Americans, the group was nevertheless conservative in their ideology, as their texts contributed to the limitations placed "on progressive political groups and their causes" (Van Wienen 2002, 29-30), while they promoted a 'white view' of the American intervention, ignoring the role that African Americans may play in the war. Their choice of 
name was, therefore, not happenstance: by presenting themselves under the tradition of vigilantism, they were putting forward the underlying defining features of a specific ideology; they presented themselves as advocates in the defence of 'white' American values, as the keepers of the American democracy that would help to safeguard freedom and democracy in Europe. The Vigilantes had a duty: informing the world of the things they believed were in danger. As Edith M. Thomas's closing poem of Fifes and Drums, "Ride Vigilantes" claims, "Tell them who sleep - so loth to awake, / All unprepared for the storm that must break - / Tell them, Humanity's all is at stake! / Tell them, 'Tis Freedom that falls in the breach!" (Rosebault 141). Their role was to spread the word to invigilate that the values of the Republic were not violated.

\section{Fifes and Drums}

In their spreading of the American gospel of democracy, the authors appealed to the emotions of the readers. The poems "furnish a striking record of the emotional reactions of the American people"; they try to encapsulate the nation's feelings about the new role that the United States was to play in the struggle. The pro-war British poets had responded to the war by presenting the war as a great adventure, as the great battle of the British Empire, or as an honourable patriotic duty to die for the country (Murdoch 24). The Vigilantes, however, looked for a different strategy: their collection of poems was "presented to the public in the belief that men and women in every corner of the Union will find reflected in them some of the love and aspiration they themselves are experiencing for their re-discovered country" (Rosebault v).

Their poetical response resorts to different propagandistic strategies. As Alice Goldfarb Marquis has argued in "Words as Weapons: Propaganda in Britain and Germany during the First World War" (1978), the press of the period followed the eight basic methods of propaganda discussed in James A. C. Brown's Techniques of Persuasion: From Propaganda to Brainwashing (1963): stereotypes, pejorative names, selection and omission of facts, atrocity stories, slogans, one-sided assertions, pinpointing the enemy, and the bandwagon effect (Marquis 486). ${ }^{8}$ The poems in Fifes and Drums follow some of these propaganda techniques, namely the use of slogans, the bandwagon technique and the pinpointing technique. They were meant to appeal to common American ideals so as to motivate American readers to support the cause.

The musical resonances of the title of the book, Fifes and Drums, work as the first slogan. Fifers and drummers have been a symbol of the US army since the times of the American War of Independence. By choosing to gather this collection of poems under this title, from the very beginning the Vigilantes put forward one of the underlying ideological goals of the volume: Fifes and Drums is a book of 
poems that sound like martial songs, songs that can be easily remembered and repeated, and that will certainly contribute to spread a specific ideology among the American population. This is a book of poems with 'songs' for America; as a matter of fact, four of the poems are entitled "Songs of..." or "Songs to...,", namely, "The Song" by Marion Couthouy Smith (18), "A Song of Democracy" by Lee Wilson Dodd (44), "War Song of America" by Grantland Rice (57), and "A Song of Confidence" by Theodosia Garrison (139). ${ }^{9}$

Slogans were also created through the type of poetry that the Vigilantes produced. It was simple, repetitive and memorable. They followed a strategy that had proven very effective for the British at the beginning of the war. Propagandistic poetry does not take a long time to write or publish. It can be easily read and remembered, it allows for "improvisation, rapid response" (Longley 60 ), and it is naturally a powerful tool to appeal to the readers' emotions. For example, in "The Song" (18-21), Marion Couthouy Smith imitates the style of "The Battle Hymn of the Republic" and ends each of the stanzas with similar linguistic phrases: "a song is sounding on," "its call is sounding on," "its call is sounding on," "that still is sounding on," "her soul is marching on," and "while God is marching on." These lines echo the closing lines of each stanza in Julia Ward Howe's anthem. At the same time, Couthouy Smith interweaves three of the original stanzas from "The Battle Hymn of the Republic" in her own song. Thus, she takes the American tradition of the American Civil War and updates it to create the new patriotic message for the First World War. ${ }^{10}$

In "Peace with a Sword (22-23), Abbey Farwell Brown follows a similar pattern. She ends each of the stanzas in the poem with a couplet and each of them has similar rhyming and linguistic patterns that contribute to convey the effect, and the message, that she wants to send to her reader. The first line of each of the closing couplets refers to "the sword" ("even with a sword," "the freeman's sword," "yeah, "with a sword," and "'Peace, with a sword!"'), while the second line includes a litany: "Help us, O Lord!" - repeated in the first, third, and final stanza - and "Not this, O Lord," which appears in the second stanza. The religious and Puritan background of the United States acts as a guiding pattern in Farwell Brown's poem. The image of "peace with a sword" is borrowed from St. Matthew 10:34. In it, Jesus claimed: "think not that I am come to send peace on earth: I came not to send peace, but a sword"; just like Jesus had warned his disciples that his arrival would cause trouble, Farwell Brown seems to acknowledge that despite the desire of the United States to preserve peace, now they are involved in the struggle their duty is "in godly liberty" to "unsheathe the patriot sword in times of need" (23). The Americans must wield the sword to keep the American gospel and founding values alive.

The poem turns into a poetic jeremiad of war, as do other poems such as "The Test;" "Marching with Papa Joffre," that I shall discuss later in the essay; or the already mentioned "Ride, Vigilantes." The authors underscore what Sacvan 
Bercovitch defined as "the typology of America's mission" (93). In his much influential study, The American Jeremiad (1978), Bercovitch argues that the Puritan jeremiad is a rhetorical tradition in American literature that has turned into a specific American genre. Jeremiads are usually long sermons with repetitive structures that build upon the idea that God's punishment is a sign of being the elect and is perceived as an opportunity for society to repent, redeem, and improve (6-8). ${ }^{11}$ In these cases, the poetic Jeremiads remind the citizens of the United States of their duty while they go back to the ideals of honour and self-sacrifice upon which the republic had been founded. In "The Test," Ameline Josephine Burr reminds American citizens of the economic and personal efforts that they had to make "to help dear Liberty to live" (138). With a series of rhetorical warnings, she reminds citizens that "words are not the price / at which the wares of God are sold" (138), but citizens must be willing to sacrifice their "own flesh" and lend any of their gold for the war cause (138).

Regarding the portrayal of the enemy, the Vigilantes refrain from including any poem that refers to German atrocities in the volume. As opposed to some of the examples that were found in the American press of the period, Fifes and Drums does not include any references to the German as the "evil Hun." ${ }^{12}$ The only two poems that deal with German matters are "The Kaiser" (77-78) and "The German-American" (66). In the first one, Florence Earle Coates portrays the fall of the German leader. Before the war, the Kaiser was "the monarch of the hour!" (77), the man who stood alone "in sovereignty sublime," who used to be a "uniquely great," "lofty in courage, wise, above his time" (77). However, in 1917, the Kaiser stands "lone today," with his "throne ensanguined, his bright aegis dime" (77). The view of this fallen man makes the poet exclaim: "what spectacle more sad!" (78).

In "The German-American," Katherine Lee Bates addresses to the large German community in the United States. ${ }^{13}$ The foreign-born workers in the United States were one of the most important targets of the propaganda machine, "on the assumption that [their] loyalty to [their] homeland might complicate [their] attitude about the war" (Harries and Harries 178). This was particularly challenging when writing to the Germans in America, as they might have felt incapable of joining the war effort in their new land. Lee Bates writes to those dutiful German-Americans that have already supported the American side of the struggle. She opens the poem by honouring those Americans of German origin who remember "the old, enchanted dream-song of the Rhine" (66), that is, their original motherland. The author traces the journey and origins of these German-Americans and acknowledges that they are still, somehow, alien in a foreign land, "still strange in speech and manner" (66). Yet, despite their German origin, she reminds the reader that their honour relies on the fact that they keep their "flighted faith" with the American "young Freedom" (66). These German Americans hail "the Starry Banner" and have now become true American patriots, "by duty, not by birth" (67). 
The poems also explore the existing links and newly created bonds with the Allies, in pieces such as "To the Allies" (74) by Laura E. Richards, "Our Flag in France" (96) by Marion Couthouy Smith, "Marching with Papa Joffre" (102) by Percy MacKaye, or "A French Captain" (117) by Amelia Josephine Burr. In "Marching with Papa Joffre" (102-104), Percy MacKaye cheerfully portrays the arrival of Marshal Joseph Joffre, known as Papa Joffre, in the United States in late April 1917. Joffre, "blue jacket and reed breeches and mustachios / gleaming white" (102) has arrived in America, "with a Tommy on his left hand and a Johnny / on his right [...] to give to America his Godspeed for the fight" (102). The Johnny (the American soldier) has joined the Tommy (the British), and the Poilu (the French) to "make free men, now and evermore" (103). In these lines MacKaye portrays the bonds that were created among the Allies on both sides of the ocean. More importantly, MacKaye creates a poetic Jeremiad through his repetition of the expression "Vive la -Vive la France" (often accompanied by "Viva l'Amerique!," "l'Angleterre" or "Vive l'Alliance"), as well as through the interweaving of religious values with democratic principles: "We are marching in alliance that our faith may be / restored; / We are fighting, we are cheering, for a nobler / world-accord; / we are praying, through the tempest, unto Lib-/ erty, our Lord" (104).

Yet, the most recurring elements in Fifes and Drums are the idea of America and the American Flag. Six poems are addressed to America: "America Unafraid" (13) by Charles Hanson Towne, "To America" (33) and "America" (88) by Lee Wilson Dodd, "To All Americans" (55) by Amelia Josephine Burr, "America in Arms" (71) by Percy MacKaye, or "America, To Arms!" (91) by Blanche Shoemaker Wagstaff; in them, America becomes a theme, a central object of attention, in keep with Bercovich's claims about America as a symbol of identity that "has united nationality and universality, civic and spiritual selfhood, secular and redemptive history, the country's past and paradise to be, in a single synthetic ideal" (176). America, the poets claim, "will wake / to the stern task before her" (Rosebault 13); America, "the anxious Mother of unhasty men" will offer "noble" answers" to those who ask "are you for ease or honor?" (89), and the answer will naturally be that she is for "the rights of living men, in peace of war"; Americans in this struggle "shall prove if we are clay or steel" and will prove themselves "clean of untruth and fear and greed / free faithfully to serve the need / of God, wherever he may lead" (55-56).

The American flag also becomes a symbol in the already mentioned "Our Flag in France," as well as in poems such as "The Flag Goes Up" (38) by Amelia Josephine Burr, "The Flag" (53) by George E. Woodberry, or "The Stars and Stripes" (64) and "The American Flag" (98) by Theodosia Garrison. All these poems had a common goal: to mobilise the American people and to make them aware - through symbols such as the American flag or the allegory of the American nation - of the crucial role that the Union was to play in this struggle. The war 
would perpetuate, and even strengthen, American democratic values and that is why the founding ideals of the American nation, "life, freedom and the pursuit of happiness," are referred to in most of the poems in Fifes and Drums.

\section{Conclusion}

The power of rhetoric put forward through the use of songs and Jeremiads were some of the strategies that these authors successfully used to mobilise minds and opinions. These resources helped to construct an American view of the war that was shaped around honourable ideals. This was not new, neither in American literature nor in the history of literature in English. From the epic tradition of Beowulf to Henry V's speech at the battle of Agincourt, there are numerous examples throughout the history of English-speaking literature that revolve around this noble conception of warfare. Henry V's "we few, we happy few, we band of brothers" (Shakespeare 291) are, in this case, the American citizens that were caught in a remote struggle that was hard to understand for Americans and that could only be portrayed in terms that related to their own American ideology and culture. If we have an even deeper look, we must point out that these elements - the American flag, the idea of America as Promised land, and the American people as the elect who must protect civilization - do not differ so much from the elements that still pervade the American political discourse of today. In fact, they are at the heart of the debate in the Trump era.

The noble ideals may have died with the First World War, but the ideology behind some of those ideals still prevails. For this reason, one hundred years after the Armistice, the poems published in Fifes and Drums deserve consideration. Their literary value may not be as innovative as the poems written by the war poets or as sophisticated as the poems of avant-garde artists such as T. S. Eliot. Yet, they give evidence of a rhetorical struggle, of a "war of words" that was equally important to Americans as the actual involvement of fighting men in the war. Moreover, the poems help us in our understanding of the past that, unfortunately, scarily resembles the world of today. By looking at the poems that were written in 1917, and how they were used back then, we may remember that words can become weapons as powerful as the sword. The way we used words and poetry in the past may help us understand the present, and even help us shape our future.

\section{Notes}

1 The meeting was probably "the most important gathering of creative and academic writers ever assembled for an official purpose in the history of English letters" (Buitenhuis 14). On 2 September 1914, Charles Masterman had 
summoned a group of male British authors to a meeting at Wellington House. Two weeks later, the attendees published the Authors' Manifesto supporting the war, signed by fifty-four distinguished British writers such as Sir James M. Barrie, Arnold Bennett, R. H. Benson, G. K. Chesterton, Arthur Conan Doyle, Thomas Hardy, or H. G. Wells, and a few women such as May Sinclair. Rudyard Kipling and Sir Arthur Quiller Couch had also been invited, but as they were unable to attend the meeting in person they sent messages offering their services (see Buitenhuis, Hynes and Prieto).

2 Gelett Burgess (1866-1951) is mostly known for founding the humorist magazine The Lark, one of the magazines of the American cultural radicalists of the fin de siècle. These magazines are thought to have contributed to the foundation of modernism in America (Knight 29). Gertrude Atherton (1857-1948) belonged to the group of European Americans such as Henry James or Edith Wharton, she wrote extensively on her travels and was a prolific writer of fictional biography (see Petrie); Amelia Josephine Burr (1878-1968) was an American poet and novelist who was also a Red Cross Member during the First World War. She became one of the most prolific American war poets (Van Wienen 2002, 320). Irvin S. Cobb (1876-1944) was an American journalist, particularly popular in his time as the author of humorous columns. He was the country's highest paid journalist and even hosted the Oscars in 1935 (see Prieto 134-135). Other authors who joined the Vigilantes were prominent poets in the United States at the time such as the Edith M. Thomas (1900-1909); the imagist Amy Lowell; Vachel Lindsay (1879-1931), who promoted the use of poetry as an art form of the common people; Edgar Lee Masters, author of the Spoon River Anthology (1915); Southern novelist George Washington Cable (1844-1925); and Pulitzer Prize winner Hamlin Garland (1860-1940) (Piep 178).

3 Cases in point are Catherine Reilly's groundbreaking Scars Upon My Heart: Women's Poetry and Verse of the First World War (1981), Nosheen Khan's Women's Poetry of the First World War (1988), Vivien Noakes's Voices of Silence: The Alternative Book of First World War Poetry (2006), Stuart Sillars' Fields of Agony: British Poetry of the First World War (2007), Tim Kendall's The Oxford Handbook of British and Irish War Poetry (2007) and Poetry of the First World War: An Anthology (2013), and Santanu Das's critical collection of essays The Cambridge Companion to the Poetry of the First World War (2013). All these studies include examples or discussion, among others, of the voices of women poets who wrote about the struggle from an alternative perspective to the one provided by the soldier-poet, as well as examples of propagandistic popular poetry, colonial voices, and modernist forms.

4 In doing so, Van Wienen seems to follow the path initiated by authors such as Brian Murdoch who in the preface to Fighting Songs and Warring Words (1990) justifies the need to study "pro-war poetry" as a popular form during 
the First and Second World War. Murdoch argues that "some of the war poetry accepted as canonical in English, for example, has become widely read only relatively recently, and then in limited context, while a great range of relevant material had (and sometimes still has) a popularity of a different and in some cases far wider kind" (x).

5 In Part 5 of Rendezvous with Death, Mark Van Wienen anthologises thirtythree poems published in 1917 (155-207). Four of the authors who contributed to Fifes and Drums, Katharine Lee Bates, John Curtis Underwood, Edith M. Thomas, and Amelia J. Burr, are included in the anthology, but the poems Van Wienen selects do not appear in the 1917 collection.

6 The United States had a "distinctive relation to the Great War" that is mostly explained due to the physical distance from the event (Matthews 217). Other remote English-speaking areas such as Canada, Australia, or New Zealand joined the war in 1914 because they were still under British dominion. The United States, on the contrary, entered the struggle only a year and a half before the Armistice. The generation of young Americans that fought in Europe was not as deeply influenced - and traumatized - by the trench experience, the constant exposure to gas attacks, the incessant bombing, and the stalemate as were the soldiers from other countries. In consequence, the literary responses to the war were not as numerous or influential as they would be in other countries. In addition, the American soldier-poets were not as impelled to contest the genteel tradition established by the "poets of the Empire" like Ruyard Kipling or Rupert Brooke, who had defended the honorability of war and the soldiers' patriotic duty at the beginning of the conflict. Nevertheless, those fiction writers such as Hemingway or Dos Passos who volunteered in the war and wrote about their experiences as ambulance drivers before the United States joined the struggle have achieved canonical status in the collective imaginary of the literature of the First World War. Their works are in keep with the premises established by Fussell in The Great War and Modern Memory due to the autobiographical status of their works and the anti-war tone employed by the authors, resembling other canonical texts such as Remarque's All Quiet on the Western Front or Robert Graves' Goodbye to all That, both published in 1929.

7 Further information on the history of vigilantism in America can be found in Madison 1973, Brown 1975, Culberson 1990, Calman et al. 2002; the relationships between vigilantism and violence and radical organisations has been explored in studies such as Waldrep 2006 or Cohen 2007, among others.

8 Pinpointing the enemy is often used in war situations to present a complex problem in simple opposing terms of right and wrong whereas the bandwagon technique uses peer pressure to compel an audience to join a cause because so many people have already joined it. 
9 A fifth poem, "Marching with Papa Joffre," by Percy MacKaye, is subtitled 'A Song to Fifes and Drums' (102).

10 Excerpts from "The Battle Hymn of the Republic" were often used in the United States during the First World War. For example, the journalist Irvin S. Cobb titled his book about his experience in Europe as a war correspondent as The Glory of the Coming: What Mine Eyes Have Seen of Americans in Action in this Year of Grace and Allied Endeavor (1918), adapting from the opening lines of Julia Ward Howe's "Battle Hymn of the Republic": "mine eyes have seen the glory of the coming of the Lord." As I have argued elsewhere, Cobb borrowed from Ward Howe's song to mark the American sense of duty in the war and to present the arrival of the American Expeditionary Forces in Europe as a glorious body to the rescue of civilisation (Prieto 143).

11 Well-known Jeremiads are John Winthrop's sermon "A City upon a Hill" or African-American texts such as The Narrative of Frederick Douglass and the sermons of Martin Luther King Jr. (see Hower-Pitney 1986).

12 During the neutral years, pro-Allied texts emphasised the stories of atrocities committed in "plucky little Belgium" by the invading armies and the Germans were presented as inhuman barbarians who had attacked a "tiny defenceless country" (Ross 47). On 27 May 1915, every New York newspaper had published the Bryce Report, denouncing attacks against Belgian civilians by the German troops. In 1916, German Atrocities: An Official Investigation was published to supplement the Bryce Report on the atrocities committed in territories other than Belgium (Morgan 2). As John Horne and Alan Kramer argue in German Atrocities 1914: A History of Denial (2001), the war was conceived in terms of moral justification, and to the neutral powers it did not matter which side made a better case but "which held the higher moral ground" (250). The case of the Allies defending Belgium against an alien invader, combined with the rumours of the questionable methods employed by German militarism, was therefore more favourably received in America than the German claims about the rightness of their cause (261).

13 At the beginning of the war, the population of the United States had a positive disposition towards Germany (St. John III 2010, 38). In August 1914, the German reading population of New York City had eight dailies, five weeklies, two Sunday papers, and one semi-monthly paper (Ross 107). Americans had historical ties with Germany; much of its population was of German origin, and many people still had relatives and friends in Europe. Additionally, German culture had influenced American education and language, and was very much present in the American collective unconscious. German American immigrants, just like many other groups of immigrants in the United States, had "settled in enclaves where they could enjoy their own language and culture" (Manning 16). This changed after gradual suspicion on German American communities started to arise in the United States (Manning 16), especially after 
events such as the sinking of the Lusitania and the Zimmerman Telegramm gradually shifted public opinion towards the Allies. Members of the government started to appeal to this German Americans as members of the Union, with claims against "hyphenated Americanism" (Manning 16).

\section{References}

Axelrod, Alan. 2009. Selling the Great War: The Making of American Propaganda. New York: Palgrave Macmillan.

Bercovitch, Sacvan. 2012 [1978]. The American Jeremiad. Madison: University of Wisconsin Press.

Brown, Richard Maxwell. 1975. Strain of Violence: Historical Studies of American Violence and Vigilantism. Oxford and New York: Oxford University Press.

Buitenhuis, Peter. 1989. The Great War of Words: Literature as Propaganda 1914-18 and After. London: Batsford Ltd.

Calman, Anna S. and Charles Doyle. 2002. Vigilantes and Unauthorized Militia in America. New York: Novinka Books.

Cobb, Irvin S. 2012 [1918]. The Glory of the Coming: What Mine Eyes Have Seen of Americans in This Year of Grace and Allied Endeavor. USA: Forgotten Books.

Cohen, Michael. 2007. "The Ku Klux Government: Vigilantism, Lynching, and the Repression of the IWW." Journal for the Study of Radicalism 1. 1:31-56.

Creel, George. 1920. How We Advertised America; the First Telling of the Amazing story of the Committee on Public Information that Carried the Gospel of Americanism to Every Corner of the Globe. London and New York: Harper $\&$ Brother Publishers.

Culberson, William C. 1990. Vigilantism: Political History of Private Power in America. New York: Greenwood Press.

Das, Santanu, ed. 2013. The Cambridge Companion to the Poetry of the First World War. Cambridge: Cambridge University Press.

Fussell, Paul. 2000. The Great War and Modern Memory. Oxford: Oxford University Press.

Harries, Meirion, and Susie Harries. 1997. The Last Days of Innocence: America at War, 1917-1918. New York: Vintage Books.

Horne, John N., and Alan Kramer. 2001. German Atrocities, 1914: A History of Denial. New Haven: Yale University Press.

Hower-Pitney, David. 1986. "Wars, White America, and The Afro-American Jeremiad: Frederick Douglass and Martin Luther King, Jr." The Journal of Negro History 71: 1.4: 23-37.

Hynes, Samuel. 1992. A War Imagined: The First World War and English Culture. London: Pimlico. 
Jeffrey, Caitlín Marie Thérèse. 2007. “Journey Through Unfamiliar Territory: American Reporters and the First World War." PhD diss, University of California.

Kendall, Tim, ed. 2007. The Oxford Handbook of British and Irish War Poetry. Oxford: Oxford University Press.

—. ed. 2013. Poetry of the First World War: An Anthology. Oxford: Oxford University Press.

Khan, Nosheen, ed. 1988. Women's Poetry of the First World War. Lexington, Kentucky: The University Press of Kentucky.

Knight, Melinda. 1996. "Little Magazines and the Emergence of Modernism in the "Fin de Siècle." American Periodicals: 6: 29-45.

Longley, Edna. 2005. "The Great War, History, and the English Lyric." The Literature of the First World War. Ed. Vincent Sherry. Cambridge: Cambridge University Press. 57-84.

Madison, Arnold. 1973. Vigilantism in America. New York: Seabury Press.

Manning, Mary J. 2014. "Being German, Being American." Prologue-Quarterly of the National Archives and Records Administration 46. 2: 15-22.

Marquis, Alice Goldfarb. 1978. "Words as Weapons: Propaganda in Britain and Germany during the First World War." Journal of Contemporary History 13. 3: 467-498.

Matthews, John T. 2005. "American Writing of the Great War." The Literature of the First World War. Ed. Vincent Sherry. Cambridge: Cambridge University Press. 217-242.

Mock, James R. and Cedric Larson. 1939. Words that Won the War; the Story of the Committee on Public Information, 1917-1919. Princeton: Princeton University Press.

Morgan, John H. 1916. German Atrocities: An Official Investigation. New York: E. P. Dutton \& Company.

Murdoch, Brian. 2009. Fighting Songs and Warring Words: Popular Lyrics of Two World Wars. London and New York: Routledge.

Noake, Vivien. 2006. Voices of Silence: The Alternative Book of First World War Poetry. Stroud, Oxfordshire: Sutton Publishing.

Petrie, Windy C. 2013. "Gertrude Atherton's Europe: Portal or Looking Glass?." American Writers in Europe. Ed. Asya Ferda. New York: Palgrave Macmillan. 55-74.

Piep, Karsten H. 2009. Embattled Home Fronts. Domestic Politics and the American Novel of World War I. Amsterdam; New York: Rodopi.

Prieto, Sara. 2018. Reporting the First World War in the Liminal Zone. British and American Eyewitness Accounts from the Western Front. Cham, Switzerland: Palgrave Macmillan.

Quinn, Patrick J. 2001. The Conning of America: The Great War and American Popular Literature. Amsterdam; Atlanta: Rodopi. 
Reilly, Catherine, ed. 1981. Scars Upon my Heart: Women's Poetry and Verse of the First World War. London: Virago.

Rosebault, Charles J., ed. 1917. Fifes and Drums: A Collection of Poems of America at War. New York: George H. Doran Company.

Ross, Stewart Halsey. 1996. Propaganda for War: How the United States Was Conditioned to Fight the Great War of 1914-1918. Jefferson: McFarland and Company Publishers.

Sanders, Michael and Philip Taylor. 1982. British Propaganda during the First World War, 1914-1918. London: Macmillan.

Shakespeare, William. 2005. Henry V. Ed. T. W. Craik. London: Routledge.

Sillars, Stuart. 2007. Fields of Agony: British Poetry of the First World War. Tirril: Literature Insights, Humanities e-books.

St. John III, Burton. 2009. "An Enduring Legacy of World War I: Propaganda, Journalism and the Domestic Struggle over the Commodification of Truth." War and the Media. Essays on News Reporting, Propaganda and Popular Culture. Ed. Paul M. Haridakis, Barbara S. Hugenberg, and Stanley T.Wearden. Jefferson: McFarland Company. 147-162.

—. 2010. Press, Professionalization and Propaganda: The Rise of Journalistic Double Mindedness 1917-1941. Amherst: Cambria Press.

Taylor, Philip M. 1980. "The Foreign Office and British Propaganda During the First World War." The Historical Journal 23. 4: 875-898.

Underhill, Lonnie E. 2017. "Hamlin Garland: A World War I 'Vigilante,' 19171918." Journal of the West 56. 2: 71-88.

Van Wienen, Mark W. 1997. Partisans and Poets: The Political Work of American Poets in the Great War. Cambridge: Cambridge University Press.

-. 2002. Rendezvous with Death: American Poems of the Great War. Urbana and Chicago: University of Illinois Press.

Waldrep, Cristopher. 2006. Lynching in America: A History in Documents. New York and London: New York University Press.

Whalan, Mark. 2014. "Literature (USA)." 1914-1918 online. International Encyclopedia of the First World War. Ed. Ute Daniel, Peter Gatrell, Oliver Janz, Heather Jones, Jennifer Keene, Alan Kramer, and Bill Nasson. Berlin: Freie Universität Berlin. https://encyclopedia.1914-1918-online.net/article/literature_usa?version $=1.0$ 

Natalia Stachura

(iD) https://orcid.org/0000-0001-5111-6351

independent scholar

\title{
British Film Propaganda in the Netherlands: Its Preconditions and Missed Opportunities
}

\begin{abstract}
British film propaganda directed at neutral countries was meant to strengthen the pro-British attitude or at least weaken pro-German sentiments in the neutral countries. Directed at the wide strata of neutral societies as well as at intellectual, military and economic elites, factual films from the battle lines were believed not only to counteract German propaganda but also to overshadow hostile actions taken by British government against economic and political freedoms of the neutrals. This article is an attempt at understanding the reasons for the eventual failure of British film propaganda in the Netherlands. While mentioning various conflict areas between the countries, it focuses on cultural entanglements and cultural networks that developed, though precariously, throughout the war. The neglect of existing connections between British and Dutch filmmakers and the hesitant if not hostile attitude of War Office Cinematograph Committee towards expensive adaptations of literary works, and feature films in general, might be perceived, the article argues, as one of the core reasons, along political and economic tensions, why Britain lost the battle for Dutch cinema audiences.
\end{abstract}

\section{The Shifting Paradigm of First World War Studies}

The recent surge of publications related to the centenary of the First World War brought, among other things, an important shift to perceiving the war as a global affair where many countries were dragged into fighting, against their will and national interest. The entanglement of neutral countries, and violation of their neutrality by belligerents, have been persistent, if marginal, subjects in research, and they have been recently re-valuated: "Par ailleurs, l'expérience des pays neutres a longtemps été négligée par les historiens de la Première Guerre mondiale, ce qui a constitué un obstacle à l'émergence d'une histoire globale du conflit" (Compagnon and Purseigle 50) ["The experience of neutral countries was, for a long time, neglected by historians of the First World War, what caused an obstacle in emergence of a global history of the conflict"; trans. N.S.]. Therefore, an inclusive and comparative approach could help to understand the nature of the global war, the multiple forms of 
entanglement of the neutrals, and the change in the concept of neutrality (Tames 277-280).

The specific quality of this global war meant that even remote overseas territories became involved in the conflict in many ways, including entanglements in economy, migration or transportation. The war affected distant countries as much as it did the neutral countries in Europe, and in "Géographies de la mobilisation et territoires de la belligérance durant la Première Guerre mondiale" (2016), Olivier Compagnon and Pierre Purseigle provide many examples of such acts of violation of neutrality in different continents and culture circles. The Dutch case was already subject of relatively extensive research: a large bibliography of British, American and Canadian research concerning the Netherlands during the First World War can be found, i.e. in Wim Klinkert's Defending Neutrality: The Netherlands Prepares for War, 1900-1925 (2013), and in the recent decades many Dutch publications concerning various aspects of the Dutch and colonial experience have appeared, among them Paul Moeyes's Buiten Schot: Nederland tijdens de Eerste Wereldoorlog 1914-1918 (2001), Kees van Dijk's The Netherlands Indies and the Great War (2007), and Conny Kristel's De oorlog van anderen: Nederland en oorlogsgeweld, 1914-1918 (2016). The wealth of Dutch monographs describing the difficulties in maintaining neutrality must be put into a wider context of re-evaluating the First World War experience in national historiographies of the neutrals (e.g. Carden, Reiter). Numerous attempts at understanding the national experiences result in revival and reframing of the concepts of historie croisee/entangled history, or intercultural and cross-cultural transfer and exchange, including Michel Espagne's "Sur les limites du comparatisme en histoire culturelle" (1994), Michael Werner's and Bénédicte Zimmermann's "Penser l'histoire croisée: Entre empirie et réflexivité" (2003), Manuela Rossini's and Michael Toggweiler's "Cultural Transfer: An Introduction" (2014), and Sebastian Conrad's and Shalini Randeria's Jenseits des Eurozentrismus: postkoloniale Perspektiven in den Geschichts- und Kulturwissenschaften (2002).

Wim Klinkert, a distinguished Dutch historian of warfare, stated that "the idea that insight into the specific internal circumstances and national political and military culture of a state is vital for understanding its foreign and military policy." This insight shall be combined with two other approaches, as put forth by Klinkert:

Second, for a real appreciation [of] the internal developments transnational developments have to be taken into account, as no country exists in a void. Third, a comparative approach can foster an understanding of national histories and is essential for asking the right and relevant questions. So, only the combination of transnational and comparative approaches can put the national in their proper perspective and can contribute to a better understanding of the period of World War I. (2013a, 4) 
According to many of the newer studies of neutrality, the global war could be understood not only as a rupture of trust between nations, and destruction of pre-war international bonds between politics, economy, culture, art and entertainment, but also as a time when new networks were established, at least in the cultural sector. The outbreak of the First World War resulted in intense cultural mobilisation of belligerent and neutral nations alike. In both cases, cultural mobilisation was strongly encouraged and influenced by official factors: belligerent governments operated via propaganda officers, trying not only to preach to the converted, but also to reach the hesitant or hostile groups. Among new means, still mistrusted and often misjudged as this article tries to argue, of cultural mobilisation was the film, believed to cross national, cultural and social borders to and move audiences towards expected actions or attitudes.

Almost directly after the outbreak of hostilities neutral countries became the focus of belligerents' propaganda. The Allied and the Central Powers tried to win neutrals for their cause, if not counting on actual political and military support, then at least on sympathy and respect, or on keeping a country out of war. As the war progressed, the firm belief in the persuasive power of the moving image grew by the Allied and Central Powers alike, reaching its peak in 1916, progressing and developing into many, sometimes unexpected, directions, including war documentaries, newsreels, features, literary adaptations, comedies, social dramas, cartoons, travelogues, educational and industry films: "the second report of Wellington House recognized the cinema as being the 'Bible' of the working classes of most countries who would be little affected by books and pamphlets" (Sanders 136).

The Kingdom of the Netherlands and its overseas territories appear, in the documents of the Foreign Office, as the areas which could have been, with carefully orchestrated propaganda, eventually won over for the British case, or where at least German influences could have been balanced with the British vision of war for justice and freedom. Film and other forms of propaganda, including press articles, pictorial magazines, lectures, translations of hallmarks of literature, were supposed to reach Dutch citizens, incline them favourably towards Great Britain, and weaken pro-German sentiments, which were believed to be relatively strong there. The film was considered a very appropriate medium meant in the first instance to reach wide masses throughout the Dutch empire; its allure should have also appealed to higher social classes, including Dutch civil and military officers. Despite the efforts of British propaganda officers, diplomats and their Dutch co-operators, the impact on the Dutch cinema audiences in Europe, Dutch East- and West Indies, and Dutch Guinea was far from satisfying.

There are several reasons for the problematic reception of British film propaganda in the Netherlands: strained political relations, including constant economic tensions and periods of open hostility, whose most important cause was the refusal of the Dutch government to stop trading with Germany. Cultural differences, moderate commitment of British government to propagandist actions in the 
Netherlands, permanent delays in delivery of high quality films, and the Dutch policy of neutrality, did not facilitate the delivery of propagandist message to cinema screens in the Netherlands. It appears questionable whether, in a time of increasing political pressure from Britain, film propaganda might have had the persuading power ascribed to it by its acolytes.

Still, after a closer scrutiny of British sources, some more optimistic conclusions can be reached, especially with regard to the collaborative network of Dutch and British film makers. This network existed long before the war and expanded even in wartime, while it appeared to be unknown to, or neglected by the British Foreign Office. This article searches for answers why the British apparently ignored these connections and they did not try to build on them to create a more complex system of film propaganda.

Another factor in favour of British film propaganda was the near elimination of two distribution centres in Brussels and Berlin, which were crucial for Dutch film trade. In wartime London became the unique distributor of British and Allied films for the neutrals and, ideally, the British distributors could have had the decisive power over what Dutch cinema audiences were to watch. Still, this chance appeared to have been missed, mainly due to the maritime trade blockade, inefficient bureaucracy, and constant trade tensions between both countries. The involvement of the British General Consul in Rotterdam, Ernest Maxse, in distribution of the film propaganda was also quite unique, as many British diplomats in other parts of the world were less experienced and far less willing to commit to the case (Reeves 1983, 474-476). Additionally, one must keep in mind that British war documentaries, most notably The Battle of the Somme (1916), were astonishing achievements and impressive commercial successes, at least until the second quarter of 1917 when even the British audiences grew tired with battle films (Reeves 2003, 28).

British propaganda had therefore some initial strong points which might have proved useful: experienced diplomats committed to the case, successful film titles of great pictorial and narrative novelty and good technical quality, competitive Dutch distributors ready to blackmail each other to receive monopoly for screening of British films (Dibbets and Groot), and keen cinema audiences looking out for new films. Geographical vicinity, the crucial role of London as a new distribution centre of American (and British) films, as well as British attempts to control and regulate all aspects of Dutch sea trade might have asserted a success of British film propaganda. The long-term relations between the two cinematographies, reaching back to the beginnings of the cinema in both countries, and the shared interest in scientific and educational potential of the new medium, might have been played in favour of British war effort.

On the other hand, however, it appears highly questionable whether even a perfectly managed and massive effort in film propaganda (which was obviously not the case) could have been of a great importance in a country harassed by frequent British infringements of its political neutrality and economical freedom 
of trade. Thus, the seemingly unexpected failure of British film propaganda in the Netherlands deserves closer examination: although the British consulate offered competitive material, dealt directly with Dutch film traders, monitored the attitudes and sentiments in the Netherlands and consulted its actions with Wellington House, the distribution of British official war films turned out to be more problematic than anybody could have expected. The famous The Battle of the Somme, which was supposed to be an unequivocal success of British film propaganda, became a source of outrage in the Netherlands (see Blom 2001, Buelens 2010, Dibbets and Groot, Kristel 2007). Most of the later official films were met with little interest, became prohibited by local censors or circulated, cut in pieces and intersected into Dutch-compiled newsreels through urban and rural areas of the country. The fate of British war films in Dutch colonies was similar: they usually reached the colony with an enormous delay, and had to compete against French war propaganda, which was delivered more regularly and better advertised. Moreover, British films were often banned in Dutch colonies by local authorities due to protests of German minorities (van Dijk 317-352).

The Dutch policy of neutrality was certainly one of the sources of the failure of the British film propaganda; still, it did not prevent the spectacular successes of French war melodramas or the triumph of German cinema in the final years of the war. There is no simple answer to the question why productions of the emerging German giant Ufa captured hearts and minds of Dutch cinema-goers, or why Mères françaises, Alasce and L'Alsace attendait remained unequalled successes, despite many attempts made by Germans and Americans to outperform the films by Desfontaines, Pouctal, Mercaton and Hervil.

The sometimes-dramatic correspondence between London and the British consulate in Rotterdam, kept at the National Archives, sheds some light into the daily struggle against the "Teutonic spirit" apparently dominating in Dutch cinemas and influencing the minds and imagination of the Dutch society (Steward to Maxse, Rotterdam, 28 August 1917, FO 395/100/174949). At the same time, it presents some ideas of the British propaganda officers and civil servants which might have proved useful for the British cause in the Netherlands if they have been applied, even partially. While presenting some alternatives for the shortcomings of official war films, British officials apparently began exploring the possibilities of "indirect propaganda" (Guest's memorandum, 1 November 1917, FO 395/102/213171), but they did not make a success story out of it, as did the Germans with their "secondary propaganda" (Stiasny 27-36) or the French with their thrilling mystery and crime series, only loosely relating to the war. Symptomatically, two British high-budget propagandist features were designed and promoted by a politician of Canadian descent and made by an American filmmaker. One can only speculate about the possible results of the collaboration between Max Aitken and D. W. Griffith, if it started earlier. Both Hearts of the World (1918) and The National Film (1918) came out too late to be of great importance for the British case. 
This article aims to explore some unresearched or less-known records of British film propaganda in the Netherlands, therefore it mentions only in passing the fascinating and troublesome story of Dutch reception of The Battle of the Somme (Blom 2001, 2003, 278-282, Buelens 2010, 2016, Dibbets and Groot, Kristel 2007, De Zwaan). Similarly, numerous astonishing similarities between Britain Prepared and the Dutch documentary Holland Neutraal (see Aarten 2015) are only a starting point for some speculations of a more general character. By looking at pre-war personal contacts between British and Dutch cineastes, and war reports of British officers trying to develop alternative patterns of film propaganda, this article tries to investigate whether British film propaganda might have chosen other ways, strategies and actors to become more successful in the Netherlands. By neglecting existing connections and networks, I will argue, an important potential might have been lost. The unwillingness to develop alternative paths of film propaganda is, in my opinion, at least partially responsible for the lost battle for Dutch cinema screens.

\section{British-Dutch Tensions Throughout the Great War}

The strategic position of both the Netherlands and its overseas territories proved very challenging for the country's government, as it tried to keep the country out of war: "one major asset of the Netherlands that did not diminish in value during the war was its geo-strategic position. [...] This remained the belligerents' only consistent reason for respecting Dutch neutrality during the war" (Abbenhuis 261). The political tensions resulted in a discharging of the Dutch idea of neutrality and the self-assumed mission of guiding other nations towards a harmonious and peaceful existence. This idea, the most visible sign of which was the (Andrew Carnegiefounded) Peace Palace in the Hague, resulted in proclamation of the War Conventions of 1899 and 1907. In the war years the Dutch visions of international politics, impartiality and economic freedom proved futile. In the Allied propaganda, Dutch neutrality became synonymous with cowardice and lack of responsibility for the global peace and justice (Tames 277-280): "neutrality stopped being the vibrant and attractive foreign policy it seemed to be before the outbreak of war" (Abbenhuis 261).

While the Allies blamed the Dutch government for a lack of solidarity with the belligerents fighting for universal human values, it could not avert the obvious fact that " $[\mathrm{b}]$ oth the Allied and Central Powers rejected international laws and other legal recourses open to neutrals when and where it suited them" (Abbenhuis 262). This imposed on the Dutch government and society a plight of keeping their impartiality in all aspects of life to avoid or weaken the accusations of supporting one side of the conflict, and to minimize the risk of eventual invasion.

In fact, neither Germany nor Great Britain was ready to invade. "[T]he Allies did not believe it was possible to defeat the Dutch and occupy the territory 
before their enemies intervened. A German invasion of the Netherlands had to be prevented if at all possible" while "[t]he two restraining influences on Germany were the fear that the Allies might open another military front in and around the Schelde and the knowledge that it could not divert more resources to another area of conflict":

But recognising the importance of Dutch non-belligerency did not keep the Allies from extracting as many advantages as possible out of that neutrality. When these demands reached a zenith with the requisitioning of Dutch ships in 1918 and the resulting 'sand and gravel' crisis, the Allies had to make concessions to the central Powers, to keep the Netherlands out of the war. Because the stakes in the conflict were so high, the warring sides had few reservations about interfering with the rights of the neutrals. (Abbenhuis 262)

In the opening months of the war Great Britain tried to drag the Netherlands into the conflict, but "the Dutch Government politely turned down a British offer to conclude a formal alliance," feeling relatively safe after "the Prussian Chief of Staff, Helmuth von Moltke, promised in an "absolutely official' manner not to violate Dutch neutrality" (Frey 2001, 60). "Great Britain could not violate Dutch neutrality since it had entered the war to protect neutral Belgium" (Abbenhuis 261), but the Dutch closure "of the Scheldt for warships, including British deployments intended to safeguard Antwerp" was a cause of "considerable anger in London" even if "[i]n terms of international law, The Hague could not have acted otherwise. However, under the circumstances, this move clearly favoured the German armies" (Frey 2000, 60).

"A war between Germany and Great Britain" was indeed "[t]he nightmare of Dutch politics" (Frey 2000, 60), even if the risk of invasion was relatively low, the economic relationship between the Netherlands and its colonies became severely challenged. The war years were a time of permanent tensions between Great Britain and the Netherlands: from the initial refusal of the Dutch government to join forces with the Allies, through British allegations of the Dutch support for Germany, British restrictions of Dutch sea trade, British threat to integrity of Dutch colonies, the establishment of the British Ministry of Blockade in February 1916 which diminished badly the Dutch practice of re-selling imported goods to Germany, British total control of telegraph connection between the Netherlands and its overseas territories, the annexation of Dutch merchant ships by the British and American navy in March 1918, British patrolling flights over the Dutch territory, and eventually the British outrage in November 1918, when the German Emperor found refuge in the Netherlands. "The Allied seizure of Dutch ships in March 1918 followed by Germany's insistence on unlimited transport trade in April of that year brought the Netherlands to the verge of war" (Abbenhuis 261) and only the war-weariness of the belligerents protected the integrity of the Dutch territory. 
In the colonies, especially in Dutch East Indies, British officials enforced a very close collaboration of Dutch civil servants. Neutralizing the German attempts to start a Muslim rebellion at the Malacca Straits and in neighbouring territories was obviously of mutual benefit for the Dutch and British colonial systems, but the range and intensity of British pressure on the Dutch government was reaching beyond the mutual interest of two colonial powers (see van Dijk, 317-357). Marc Frey in his comparison of the Netherlands and Scandinavian neutrals during the war draw several important conclusions:

The Netherlands, more than any other country in the First World War, was caught between "the anvil of Germany and the hammer of Great Britain." Like Denmark, its policy of neutrality tended to be pro-German in military and strategic matters. Due to the very large transit trade in building materials and an enormous export of sand and gravel o the German front in Belgium and Northern France, the Netherlands came to be regarded as a "military highway" for Germany. Due to German pressure, it was the only European neutral which in 1917/18 preferred to be embargoed until the end of war instead of signing an agreement with the allies. While it was subservient to Germany's strategic interests, it had considerable influence on Germany in terms of trade, business relations, and the economy. In contrast to the Scandinavian neutrals, the Netherlands were an economic global player with a rich colonial empire, foreign investment surpassed only by that of Great Britain, France, and Germany, and valuable business connections on a large scale with the US. Particularly during the second half of the war, this role influenced German decision-making and provided the Dutch with some freedom of action. (Frey 2000, 17-18)

From the economic perspective, both German industry and British merchant marine were vital for Dutch independence: "in the pre-war period, the Netherlands had been regarded as an integral part of the German economy" (Frey 2000,15). In the imperial visions of Chancellor Theobald von Bethmann Hollweg expressed in the "September programme" (1914), "the Netherlands in particular were singled out as junior partners of the Reich - nominally independent, but in fact dominated by Germany." A similar idea of "close alliance of Germany and the Netherlands" was favoured by "[t]he, the Auswaertiges Amt, various influential newspapers, industrialists, people from the military like Ludendorff or Tirpitz, and influential members of the Reichstag" until mid-1916. The Chief of the German General Staff, Helmut von Moltke, decided to modify the initial Schlieffen plan and leave the Netherlands unoccupied, but serving as the "breathing pipe" of German war economy. Richard von Kühlmann, German minister in The Hague, ascribed to the Netherlands the role of "a neutral mediator right at our doors" (Frey 2000, 13). The degree of integration of Dutch and German economy and politics might have varied throughout the war years, but generally for Germany the Netherlands were a guarantor of well-functioning war economy.

For the Dutch trade the German economy was indispensable as source of coal and market for agricultural products. The main trade route remained the Rhine, 
hence the constant disagreement between the Dutch and British governments considering British restrictions in this matter. The British command of the sea was crucial for trade between the Netherlands and its own colonies" "if Germany was the Netherlands main trading partner within Europe then Great Britain was the only nation with a navy capable of taking, or protecting, the Dutch colonies (or at least trade routes)" (Wolf 7). It was widely believed that without British protection and support the Dutch colonies would have been defenceless against many potential aggressors: Germany, Japan, the USA, France and Great Britain (van Dijk ix-xii), in military as well as in economic sense: "what appears from all this is a bifurcation of the Dutch economy: merchants and industrials were temporarily forced to comply with the British, while banking and the extensive agricultural sector cooperated with Germany" (Frey 2000, 12).

The small and vulnerable colonial empire had to navigate very carefully between the German "devil" and the British "deep blue sea" (Abbenhuis 17). Even in October 1917, when British Navy cut off undersea cables connecting the Netherlands with the colonies, and when in March 1918 the Allied annexed about one third of Dutch merchant fleet worldwide, and when in summer 1918 British airplanes regularly patrolled the Dutch coast, Dutch government kept the policy of strict neutrality (Frey 2001, 73).

On the long run, especially British precautions taken to diminish or eliminate German war contraband were devastating for Dutch trade: "There is no doubt that the Dutch [...] felt that the British blockade infringed upon neutral rights of neutrals to trade with both groups of belligerents. But the Dutch [...] under no circumstances wanted to complicate their already strained relations with London" (Frey 2000, 6-7). The British postulate of "starving Germany" from January 1917 (Frey 2001, 65), by cutting off its supplies meant obviously also hard loses for Dutch export. It was not the first attempt to control and limit Dutch trade. Already in 1914 Sir Francis Oppenheimer (Baliol Archives) negotiated the trade conditions between the neutral Netherlands and the belligerents which led to establishing of the NOT (Netherlands Overseas Trust, Kruizinga), a private organisation "of businessmen and bankers" which "guaranteed the home-consumption of goods entering the Netherlands. All other goods not consigned to the NOT (or, in few cases, to the government) were suspect and liable for seizure." The NOT "became the model for all other bodies and institutional arrangements in neutral countries" (Frey 2000, 20). A similar organisation, Landbouw Export Bureau (LEB, Agrarian Export Office) was the second of British-enforced "regulators of the Dutch economy and $[\ldots]$ foreign policy-institutions" (Frey 2001, 65):

What facilitated the foundation of the NOT was the specific character of Dutch trade. The former East India Company, renamed Nederlandse Handel Maatschappij, still exerted considerable influence among the business community. The rather small group of leading businessmen, entrepreneurs, and bankers knew each other well. They realized that their foreign investments, the colonial trade, and their overseas 
transportations were in danger. On the other hand, they looked to the future, and they were aware that the economic development of the Netherlands were closely connected to that of Germany. Therefore, the same group of people who made blockade deals with the British were forging new business alliances with their German counterparts. On the p. 22 whole, Germany consented to the NOT, particularly during the second half of the war, because the government and the business community realized that they needed the Dutch in the post-war period. (Frey 2000, 21)

The Netherlands were thus subject to multi-layered British pressure, reaching from questioning ethical standards of Dutch policy of strict neutrality through (more or less direct) threats and limited manifestations of military power, down to the smallest aspects of economic reality. The latter, I would argue, was in many ways the most visible and irritating sign of British pressure for the common Dutch citizen and therefore the most damaging factor for the perception of Great Britain and its war aims.

\section{British Attempts to Define and Influence Dutch Cinema Audiences}

Performing war propaganda in a neutral country was a difficult undertaking, but performing pro-British propaganda in the Netherlands proved, at times, an almost impossible one. The actions of British government, sternly affecting Dutch economy and Dutch sense of dignity, resulted in hostile attitudes of many Dutch citizens towards Great Britain. Even if the Dutch "were generally welldisposed toward the Entente, mainly due their dislike of Germany" (van Tuyll 147), British restrictions and acts of violation of Dutch neutrality stimulated anti-British feelings. The files of the Foreign Office testify that the British kept a close watch of Dutch attitudes and sentiments. British officials went beyond regular reading of Dutch dailies and magazines or spying on German propaganda in the Netherlands. Not only British civil servants but also British citizens living in Dutch territories and, occasionally, Dutch citizens sympathetic to the British cause, reported to London about the actual opinions of different social groups. The British, apparently, tried to define the Dutch society in terms of British social classes. This attitude led at times to falsities and misunderstandings but was a clear sign of an effort to understand the cultural specificity of the Dutch. This understanding was crucial for designing and developing successful propaganda strategies. The misconceptions about the recipients of British propaganda were, in my opinion, one of the sources of British failure in the Netherlands.

According to an anonymous "British Resident in Holland," the Netherlands had "a larger lower middle and middle class in proportion to population than almost any other nation," therefore the "main purpose of our propaganda should be to win the middle and upper classes who are governing forces of public opinion": 
The wage earning classes and the small bourgeoisie are anti-German. But they dislike and mistrust England and do not believe she has the power nor the endurance to win the war. [...] The intellectual and upper classes are divided in their sympathies, which depend upon business interests, education, blood ties and religion. The Ultramontanes are pro-German because they regard France as Atheistic, and many Calvinists are pro-German. (FO 395/102/12077, Wicks to Carson, 16 January 1917)

Even if the Dutch "were generally well-disposed toward the Entente, mainly due their dislike of Germany," "definite anti-British feelings" remained. Instead of relating these feelings directly to British oppressive politics towards the Netherlands, British civil servants tended (at least in the preserved official documents) towards naming different groups prone for German propaganda: "The most proGerman elements were found among army officers and aristocrats, followed by members of court society, university professors, some business people, and some Catholics who disliked the French Republic. This left Germany with an influential minority on which to build" (van Tuyll 2001, 147).

The British were thus aware of relatively strong pro-German sentiments, a moderate belief in British military power and a general anti-militarist attitude of the Dutch society, and of its growing indifference towards the war among the Dutch. Already in the autumn of 1916 Alan Blakiston, a British pastor from Utrecht, one of the informers of the Foreign Office, stated that the Dutch "ignorance of war" was "simply colossal":

One of the most lamentable manifestations of the past year or eighteen months has been the growth of, not [...] war-weariness, but of a lack of interest in, and indifference towards the cause, objects and meaning, of the war. The average Dutchman is preoccupied with his own affairs; he is darkly suspicious of all his neighbours; he frankly refuses to credit the Allies with any lofty motives; he bans all belligerents alike. This attitude of mind is probably reflected in Dutch statesmanship. (FO 395/22/231749, 30 October 1916, Blakiston to Carson)

Still, despite the circumstances, British propaganda was believed, rather desperately, to be able to change Dutch attitude of indifference or suspicion into enthusiasm and admiration of British war successes. The civil servants from Foreign Office were aware that "British propaganda will always be regarded with suspicion in Holland and always subject to a heavy discussion" and therefore must be "done indirectly - best of all through Hollanders," (FO 395/102/12077, Wicks to Carson, 16 January 1917). In the case of film propaganda, the British succeeded to act through a Dutch co-operator, but the results proved far from satisfying for both sides.

The decision to focus on the distribution of the official feature-length war documentaries seemed initially the most logical one: the films offered a novelty of showing the reality of war (even if the most dramatic scenes were faked). British film propaganda was focussed on current news, relative objectivity, and seriousness. The internal and international successes of British feature-length war 
documentaries led both the officials at Wellington House and British diplomats in Rotterdam to believing that Britain Prepared (1915), The Battle of the Somme (1916), The Battle of Ancre and the Advance of the Tanks (1917) were perfect tools to reach wide social strata of Dutch society and to awake the interest of Dutch high rank military officers and civil servants. The sober, realistic way of portraying the war was seen as an antidote against German bombastic and straightforward propaganda. The unadorned pictures of British land and sea power, technical potential of the modern army might have been perceived as more convicting than French or Italian war documentaries, avoiding the directness of the British Somme.

In British eyes, seriousness should have been the key to the heart of the Dutch cinema audience. In one of his reports Alan Blakiston underlined that "the average Dutchman does not understand [the British sense of] humour," therefore the propaganda should avoid everything "trivial $[\ldots]$ out of date $[\ldots]$ [or] not in a good taste" and concentrate on messages "in good Dutch; brief and lucid, dignified in tone and free from bitterness; bristling with fact, and absolutely accurate" (FO 395/22/231749, 30 October 1916, Blakiston to Carson). From this kind of reasoning it was simple to conclude that British official war films might have been the cure for Dutch mistrust and indifference the Foreign Office was searching for. What the British did not include in their calculations was the Dutch abhorrence of militarism, although this could be inferred even from British reports quoted above and the latent pacifist potential of the war films.

Film propaganda was entrusted to the British General Consul in Rotterdam Ernest Maxse. He "joined the Consular Service in 1891 and served in Algiers, Greece, Samoa and Reunion before being appointed consul-general in Valparaiso, and then in 1913 the consul-general in Rotterdam" (West 199) where he worked until his transfer to Zurich in 1919. Working in the city known as "spy paradise" (see Kinkert 2003b, Ruis 2016), and eager to involve in actions surpassing his regular consular duties (Jeffery 69-70), Maxse revealed talent, energy and commitment, as did his collaborator, George F. Steward from the Press Department who was the decision person in film distribution (Bundesarchiv R901/71961, NOT to Firma B. Vissers, 17 September 1918). Maxse's work was judged very positively by the Wellington House (INF 4/4A, qtd. in Blom 2001, 143).

Maxse was far from overestimating the potential of British film propaganda in the Netherlands. Already in January 1917, when British official war films still enjoyed great popularity in Great Britain and worldwide (see Reeves 2003), Maxse wrote to London that of all the great titles "two copies will be sufficient, 1 copy for the trade and one for loan to various internment and refugee camps and private propaganda work" (Maxse to Montgomery, 8 January 1917, FO 395/102/214539). His moderate enthusiasm for war films was dictated by severe difficulties he had to overcome by screening in the Netherlands The Battle of the Somme in November 1916. To list only the most obvious ones, the film reached Dutch shores with a certain delay, its screening was delayed for several more weeks by the Dutch 
distributor, and when it entered Dutch cinemas on October 6, 1916, it had to compete with a French Somme film which reached Dutch screens around the same time (Blom 2001, Dibbets and Groot).

When finally screened, the film was received with mixed feelings: Dutch audience was mesmerized by the volume of British war production, fascinated by the war machinery, but outraged by the realistic pictures of death and suffering (Buelens 2010, Kristel 2007). The most problematic screening was in the Hague, where a Dutch pacifist organisation NAOR (Nederlandsche Anti-oorlogs Raad) managed to insert some strongly pacifistic intertitles into the film and therefore to modify its meaning drastically. Despite protests from the British diplomats, nothing could be done, not only to save The Battle of the Somme from becoming a tool of Dutch pacifist propaganda, but also from its being mutilated by distributors: the film was shown at high speeds to enable more viewings per day, or cut up into pieces, and inserted in variety programmes circulating through less renown locations in the Netherlands.

Distribution of the English film was left in Dutch hands, and David Hamburger remained the sole distributing partner of the Rotterdam Consulate, although many other distributors tried to obtain the rights for The Battle of the Somme which promised to be a commercial success. Hamburger claimed to have never achieved the expected financial gain. Instead, he became mistrusted by both sides: the British could not believe that their films were met with mixed feelings, reaching from awe to outrage, as was the case by the initial screenings of The Battle of the Somme, but mostly with boredom and indifference. Other Dutch film distributors, desperate to receive any new films to attract the audience, approached the British consulate with declarations of their pro-Englishness and accusations of Hamburger's alleged pro-German leanings (Blom 2003, 280-281, Dibbets and Groot 446).

Among them was Anton Nöggerath Jr., apparently unknown to British consulate and propaganda officers. This is a quite interesting fact, as Nöggerath worked from 1897 to 1908 as a film operator for the British Warwick Trading Company (Blom 1999). His British contacts included Chares Urban, Cecil Hepworth, Arthur Melbourne-Cooper and Dave Aylott. He was also married to a British actress Eleonora Fox, better known as Nellie Hope (Bischoff 57-60; De Vries and Mul 162-164). Nöggerath Jr. was forced to return to the Netherlands after his father's death, but one can presume that his personal links with British film trade did not cease after 1908.

A working knowledge of Dutch film circuit seems not to have been a seriously desired asset for British propaganda officers. While Nöggerath appears in British documents only marginally, as a curious Dutchman with a German name and British leanings (Blom 2003, 280-281), other Dutch filmmakers such as Max Binger, collaborating throughout the war with British actors and producers (filminnederland.nl), or Theo Frenkel sr., a long-term collaborator of the British early film studio in Hove at Brighton (see Delpeut 1997), seem to be totally absent in British files. Commercial features appeared beyond the range of interest of the 
Foreign Office. One can only speculate what could have happened if the British propaganda officers had included experienced Dutch and British filmmakers, who used to work together before the war, into decision-making processes of designing film propaganda for the Netherlands. The neglect of existing connections within the film trade was, in my opinion, one of the reasons behind the failure of British film propaganda in the Netherlands.

The Battle of the Somme proved more problematic than successful. The next film about the Somme, The King of England Visits the Conquered Somme Region (The King Visits His Armies in the Great Advance), was screened in the Netherlands at the end of November 1916. The openly-pro British Dutch newspaper De Telegraaf, presented the film as far less interesting than the previous one (De Telegraaf, 28 November 1916). Another newspaper, socialist Het Volk, compared this continuation of The Battle of the Somme with an Italian propaganda piece $L a$ Presa di Gorizia with ran parallel with the British one, judging the Italian film much more favourably for the terrific beauty of Alpine landscapes and lack of war horrors (Het Volk, 28 November 1916).

The King of England was screened officially in Amsterdam in the presence of Dutch high-ranking military officers, foreign diplomats and representatives of influential Dutch newspapers, and apparently the screening did not offend the strict neutrality of Dutch audience. When, however, screened in January 1917 in the Hague, the same film was banned by local authorities (FO 395/102/12446, Johnstone to Maxse, 9 January 1917). The on-screen presence of King George, King Albert, President Poincare, Generals Joffre and Haig was apparently violating the neutrality of Dutch cinema. In a city "full of Belgians who are only too glad to get an opportunity of demonstrating against the Boche, and $[\ldots]$ constitute a large proportion of the cinematograph audiences" (FO 395/102/31076/Johnstone to Montgomery, 5 February 1917) screening of any film featuring belligerent crowned heads, politicians and generals might have immediately led to riots and troubles.

Under the Dutch circumstances, The King of England proved to be a controversial film, much due to its overtly political context. The policy of strict neutrality did not facilitate the work of British propaganda officers, as multiple films produced at that time featured the members of the Royal Family, or British and Allied generals and politicians. High hopes were connected with screenings of The Battle of Ancre and the Advance of Tanks in the Netherlands. This film was believed to be able to bypass Dutch restrictions and win the audiences for the British case. The Dutch audiences were known to have a genuine interest, even a fascination with the materiality of the war (see Kristel 2007), therefore a film which focused almost entirely of the technical possibilities of a modern army might have been considered as a long-expected piece of propaganda that would run smoothly through the Dutch territory without hurting the fine sense of neutrality and impartiality.

The film premiered in Amsterdam on March 2, 1917, but the audience did not respond enthusiastically: it came two months after its London premiere, yet 
the novelty effect was already lost. One can also presume that at this stage of the conflict the war-weariness among the Dutch was on the increase. Cinema was at that time a form of distraction and an escape from the harsh reality of trade limitations and growing social unrest rather than a place where the spectators would want to be reminded once more about the war. At that time, a generation shift in Dutch film distribution took place: the older distributors, connected with European markets, gave way to younger, mostly USA-focused managers, who perceived cinema as a source of entertainment, and invested a lot of money into advertising and into the cheap chic of cinema palaces (built mostly after the war), which were gradually replacing smaller venues. The new distributors were interested in propaganda films only if there was a chance that they would turn out profit. David Hamburger was of the new generation of entrepreneurs, but was ready to compromise and search for reasonable solutions suiting both sides, focusing on commercial success but not at any price. His multiple talents, however, did not rescue the lost case of British film propaganda in the Netherlands.

The following film, The Battle of Arras, shot in April 1917 (BFI), reached the Netherlands in the autumn of 1917 and was screened countrywide at least 20 times (cinemacontext.nl), most probably in sections (FO 395/102/196650, Steward to Maxse, 3 October 1917). From the Dutch press record, one cannot infer whether the film made any impression in the Netherlands. Other official war films sent to the Netherlands included titles considered only for private screenings, as they were featuring Allied politicians and generals as well as some other films for the general public, believed to be inoffensive to Dutch sense of neutrality.

The Royal Visit to the Battlefields of France and His Britannic Majesty's Visit to His Grand Fleet, "in which the King appears [...] prominently" (FO 395/102/206901, Northam to Montgomery, 27 October 1917) belonged to the first group, while Sons of Empire, Peronne and Baupame were judged as appropriate for general public and circulated in sections throughout the country (FO 395/102/154058, Maxse to Montgomery, 4 August 1917). The fate of Women's Land Army, London Air Raids, The Story of the Drifters and General Allenby's Entry into Jerusalem remains unknown: the prints were ordered (FO 395/102/222558, Brunel to Montgomery, 20 November 1917; FO 395/102/242413, Gilmour to Steward, 20 December 1917) but it is difficult to determine whether they were screened in public, as no reference was found so far in contemporary Dutch newspapers and trade magazines. Probably the films were circulating as a part of Dutch news compilations made by cinema managers Loet Barnstijn and Anton Nöggerath Jr. Laatste Bioscoop Wereldberichten and Oorlogsjournaal as they were called aimed at balancing subjects loosely related to war delivered by Central Powers and Allied alike.

A new chance occurred when Loet Barnstijn, the managing director of HAP and a leading distribution company, contacted Steward in November 1917 expressing willingness to screen Topical Budget films within the news 
compilations, and to replace at least partially German film materials with the British news. While promising Steward "to screen the official films in roughly sixty of the biggest cinema halls in Holland" (FO 395/102/238426, Steward's Report, December 1917), Barnstijn hoped to get access to British, French and American films, distributed at that time via London. British support would have helped him to bypass trade restrictions for highly inflammable nitrate negatives, regarded as possible explosives and thus war contraband. Regular delivery of Allied features would have guaranteed Barnstijn the top position among Dutch film traders.

British officials checked whether an eventual contract with Barnstijn would have not meant a breach of contract with Hamburger. "I can arrange to send you each week about 175 or $200 \mathrm{ft}$. of Topical Films which you can dispose of to the best advantage," T. L. Gilmour wrote from the London Department of Information (FO 395/102/242413, Gilmour to Steward, 20 December 1917), still it is very questionable whether the films reached the Netherlands, as there is no trace them in Dutch archival sources. It cannot be excluded that outdated Topical Budget films might have been recycled by Dutch film industry, desperate to get new material, but no proofs of such operations were found in Dutch film databases and trade papers.

While looking at the list of British failures in Dutch cinemas, one must keep in mind the very first British feature-length propaganda film Britain Prepared (1915) and its importance and impact on Dutch film, ignored for many years. Less spectacular than its follower, The Battle of the Somme, the film proved also far less problematic for screening in a neutral country, and inspired a Dutch propaganda film Holland Neutraal: De Leger- en Vlootfilm (1917, "Neutral Holland: The Army and Navy Film"). As proved by Stephanie Aarten, both the general idea of an army and navy film, and the detailed scripts of many segments were in many cases creatively copied and translated into Dutch circumstances by the Dutch film maker and cinema manager Willy Mullens. Mullens, who was assigned by the army to make the official propaganda documentary (Moeyes 325) certainly knew Britain Prepared, as it was screened in the prestigious cinema venue in The Hague which was managed by his company Alberts Frères (cinemacontext.nl).

Despite evident similarities, the Dutch documentary was in some respects different from the British original. Not only was the navy section drastically shorter than the army one, but also the message was different: instead from proclaiming readiness for war, the Dutch film showed the readiness to keep the status quo of neutrality at all cost. In my opinion, the similarities between these two films are a marvellous case study of cultural transfer and visual influence within the cinema of that period. The case is even more interesting since Willy Mullens was allegedly pro-British but traded also with Germans (BArch R901/71951, German Embassy to Foreign Office, 25 October 1917) and screened German documentaries (FO 395/102/12446, Johnstone to Maxse, 9 January 1917). 
Interestingly, at that time Mullens was probably the only Dutch film maker who did not learn the trade in Great Britain or by cooperating with British filmmakers, unlike Frenkel sr., Nöggerath jr. or Maurits Binger, the managing director of Anglo-Hollandia (established 1919). British contacts with Dutch film trade started around 1896 and flourished throughout the pre-war period. In the early years of the cinema they included Charles Urban's travelogue Quaint Holland (1906, Blom 1996) and the record of the coronation of Queen Wilhelmina (1898, Inhuldiging Koningin Wilhelmina te Amsterdam), made for Anton Nöggerath sr. (McKernan 2013). In Great Britain, between 1910 and 1912, Theo Frenkel sr., an acclaimed Dutch theatre and film personality, directed and occasionally acted in more than 120 short films made in Urban's experimental colour system Kinemacolor, before moving to Berlin in 1913 and back to the Netherlands at the outbreak of war.

The contacts between Dutch and British filmmakers in the pre-war period were quite intense and inspiring and they did not cease after the outbreak of hostilities. Even when personal contacts with were lacking, as most probably was the case with Willy Mullens, a fairground artist who learned filmmaking in Belgium and France (Convents 186-190; Blom 2003, 44; Bishoff 34, Willems 9), new ideas and techniques got through despite the Naval Blockade.

The influence of Britain Prepared or Holland Neutraal appears unquestionable, therefore it is rather astonishing that in the British files there is neither much interest in Mullens's film, nor any reflection about its indebtedness to the British production. From today's perspective, one can presume that a great chance for promoting the British case was lost. The Dutch filmmaker adopted the British iconography of bravery, readiness and technical progress to express the Dutch sense of preparedness to defend national values. A skilful hand of an unscrupulous propaganda maker would have made wonders when such an opportunity appeared. The Mullens' film meant, even if indirectly, that the Dutch nation was imagining and projecting itself as a micro-scale replica of Great Britain. Obviously, these projections must have been handled very carefully, as the aim of the Dutch film differed strongly from the British piece of propaganda: while Urban's film showed readiness to war, Mullens focussed on preparedness to defend the country. British film was reinterpreted accordingly to the Dutch raison d'etat.

The Dutch documentary was, most probably, not the only one modelled on Britain Prepared; influences and inspirations can be also traced in French official documentary La Puissance militaire de la France. Still, both the French army and French cinema, even if severely weakened by the war, were incomparably stronger than their Dutch counterparts. The Dutch film exposed, inadvertently, the weakness of the army (Bataviaasch nieuwsblad, 6 February 1918), while the British and the French films showed impressive military potential that carried the promise of winning the war. The Dutch film did not only show the actual unpreparedness and unreadiness to defend the country but also imagined the native country on the matrix on Britishness. 
This was not a new occurrence. Long before the war, Dutch cinema was dependent on British, French and German equipment and specialists (see van der Maden 1986). Dutch self-imagining, the pre-war iconography of "Dutchness" was generated by French, German and British filmmakers (see Blom 1996) and multiplied successfully by Dutch producers in the 1910s. Still, Dutch film market opposed the French "colonisation" by Pathé in the first decade of the twentieth century (see Blom 1997), which was almost complete in the neighbouring Belgium (see Engelen 2005). Even though Dutch film makers were highly dependent on skills, techniques and images brought from abroad, and the imaginative "Dutchness" was a product of a colonial gaze of neighbouring cinematographies, they went on developing and contesting the imaginary of "clogs and tulips" (see Depeut 1997; Blom 1996). Holland Neutraal shows how foreign imaginary was internalized and recycled for domestic use.

As underscored by Manfred Pfister, "national identity is not some naturally given or metaphysically sanctioned racial or territorial essence that only needs to be conceptualized or spelt out in discursive texts; it emerges from, takes shape in, and is constantly defined and redefined in individual and collective performances" (9). In the greatest Dutch propaganda film of the wartime, Dutch national identity was performed through the imagery of British military power. This was, however, not a unique case of recycling of national imageries in wartime films. Similarly, the two projects of the biggest British propaganda features, The Hearts of the World (1917) and The National Film (1918) were developed, to a degree, as a counterpart to French features (Abel 548), such as Mères Françaises (1917), L'Alsace (1916), Mater Dolorosa (1917) or L'Alsace Attendait (1917). Moreover, The Hearts of the World is actually a remake of Griffith's The Birth of a Nation (1915). It is "[a] romance [...] set against the background of war in which Germany and France replace the North and the South" (Rogin 289).

One can only imagine that, with its great persuasive skills, British propaganda might have tried to convince the Dutch that the moral, religious, historical, colonial and economic bounds with Great Britain were stronger than the romantic allure of the "Teutonic spirit." No such effort was ever made, thus the probably greatest chance to influence Dutch audiences decisively but indirectly was lost without even being noticed by the British. The British remained unmoved and most probably unaware that Britain Prepared infiltrated and transformed Dutch imagination. Still, it is an open question whether in 1917, still holding the policy of direct (and inexpensive) propaganda in an area of second-rank political meaning, London would have opted for better orchestrated and less direct forms of propaganda in the Netherlands. 


\section{Indirect Propaganda}

The British made some efforts towards indirect propaganda in the last two years of the war. These efforts remained apparently far less successful than German "secondary propaganda" (Stiasny 27-36) Facing the failure of official war films in the Netherlands, British propagandists searched intensely for an alternative. Struggling against apparent predominance of German, Austrian or Danish films (Denmark's biggest film producer Nordisk, officially neutral, had strong German connections and was believed to support the German cause, although no proofs have been found in archives so far), G. F. Steward proved to be the most visionary and most realistic of British officials. Already in August 1917 G. F. Steward alarmed about the constant influx of Danish, Austrian and German features, which he described as "Teutonic in spirit" and having "nothing 'Western' in their conception" (FO/395/102/174949, Steward to Maxse, 28 August 1917).

Clearly, British film lost its temporary and relative advantage created by The Battle of the Somme, while Germany managed not only to create the successful state-controlled film giant Ufa $\mathrm{GmbH}$, but also booked initial successes of the "secondary propaganda": films only loosely related to war, but presenting Germans, Germany and Germanic culture in a positive light and therefore influencing indirectly the audiences' attitude (Stiasny 33). German propaganda officers not only watched and analysed the cinematic milestones of D. W. Griffith and Hervil and Mercaton (Duisberg, BArch R901/71950, WB (2) 24-29 September 1917), but also tried to understand the Dutch "ethnic soul" (Volksseele) and designed film propaganda accordingly to their judgements of the national characteristic of Dutch cinema audiences (Cürlis 1-5).

Apparently, Germans learned quickly, and the failure in neutral countries (see Dibbets and Groot 2010, Smither 2005) of bombastic military films Graf Dohna und seine Möwe and Bei unseren Helden an der Somme led to an instant change of strategy: melodramas and romantic comedies, set ideally in a scenic setting and starring the internationally acclaimed German actress and war widow Henny Porten, fantastic features made by Paul Wegener, comic relief offered by Ernst Lubitsch's comedies and detective series Joe Deebs, proved much more successful than the official propaganda. German propaganda officers decided wisely not to screen in neutral countries films with overtly propagandist message, such as propaganda cartoons John Bull (1917) or Das Säugetier (1917). The British made a similar decision, so most probably none of Lancelot Speed's propagandist were screened in the Netherlands or in Dutch colonies.

Still, while Germans applied radical changes in their propaganda strategy (they intended to speak rather to the "ethnic soul" than to "collective mind," using the powerful proto-expressionist images of Robert Wiene and Ernst Lubitsch), the British efforts turned out to be generally unconvinced about the power of indirect propaganda. The changes brought with Max Aitken, Lord Beaverbrook, were 
radical but did not avert the failure of British film propaganda in neutral countries. Aitken, from 1910s an influential player in British politics (see McEwen 1979) and from the autumn of 1916 the chairman of War Office Cinema Committee (see Badsey 2009), became the head of the Ministry of Information. The Ministry, established February 1918 from the earlier Department of Information, came into being after many turbulences in the British War Propaganda Bureau, supervised by the Foreign Office (see Sanders 1975). Aitken came up with ideas very similar to the German concept of secondary propaganda: not only did the Ministry take care to produce two fictional films, which the acclaimed American director D.W. Griffith was commissioned for, but also considered another revolutionary change, "namely abandoning the practice of releasing official films altogether and putting in its place a new, 'discreet' approach in which the provenance of the films would be concealed from the audience" (Reeves 2003, 30), an approach that had been successfully adopted by Germans. This strategy was not applied, as the war already ended.

After the Armistice, the British were eager to dissolve Propaganda Office and to forget about its activity throughout the war (Messinger 126). For many years, Arthur Ponsonby's famous definition of propaganda as "the defilement of the human soul [which] is worse than the destruction of the human body" (qtd. in Taylor 1) overshadowed the fact that in the last war years British film propaganda began to experiment with strategies of indirect influence and manipulation. One can only presume that if Griffith's both 'British' films, Hearts of the World (1918) and The National Film (1918) had reached cinema screens at the right time, they might have been great successes, in commercial and ideological sense.

In the beginning of 1918, British Propaganda Office decided to attract potential distributors in neutral countries by offering films in packages: "from January 1918 a number of commercial fiction films were included in the regular supply of official films sent overseas" (Reeves 1983, 477). This was a change suggested, among others, by a leading Dutch film distributor Loet Barnstijn. Unfortunately, by lack of records, one can only guess whether the package deliveries made for an important increase of British films on Dutch screens. Interestingly, some of the British titles which were quite popular in the Netherlands throughout the war were not mentioned in British reports. Presumably propaganda officers were not aware that, for instance, the British Ultus series were doing very well: Ultus, the Man from the Dead (1916) had been screened nearly 30 times in the war years, Ultus and the Secret of the Night (1916) however, had been screened only once during the War, while Ultus and the Three-Button Mystery (1917) reached Dutch screens in 1919. A Study in Scarlet (1914) had been screened, apparently, six times in 1915, and The Valley of Fear (1916), another Sherlock Holmes-story, also six times, in 1918.

The prospective popularity of such British pre-war films as Charles Weston's The Battle of Waterloo (1913), or its parody, Pimple's Battle of Waterloo (1913) 
can be only matter of stipulation, as the titles were most probably not screened in the Netherlands. While it is highly doubtful whether patriotic productions, such as Weston's Road to Calais (1914), Facing the Enemy (1914) or Called to the Front (1914) or Haldane's Tommy Atkins (1915) would have passed Dutch censorship, historical films would have probably entered Dutch cinemas without many difficulties.

The Cinematographic Branch in London was aware that the time of great battle films has already passed, and worked out some concepts of indirect propaganda, including

a) General interest films with a story running through them. b) Films illustrating various forms of activity directly and indirectly conducting towards the winning of the war, or illustrating events arising from or connected with war activity behind the lines of England. c) Topical films, the value of which largely depends upon their being available for exhibition within as short a period as possible after the event they depict. (FO 395/102/213171, Guest's Memorandum, 1 November 1917)

G. F. Steward believed that "indirect propaganda films would certainly find better chances of exhibition here and do much more good than the too obvious type," still insisting "that at the commencement of every film and even at the commencement of each reel there should be some short announcement that the film was produced by a British company. Let the word British appear in some form or other on every film" (FO 395/102/223309, Steward to Maxse, 14 November 1917). The decisive step towards covert propaganda was not considered at that time.

In the Memorandum, the suggested titles were divided into three categories of "Industrials," "Interests" and "Scenic": the first one included Making Cheddar Cheese, Making khaki, Ropemaking in Kent, Modern Cheesemaking in Taranaka, N.Z., Whaling Industry of Natal, Royal Porcelain Works Worcester, Birth of an Aeroplane, the second The Mighty Atom (Woolwich Creche), London Market, Grahamstown: An Historic South African Town, Dar-es-Salaam, East London, S. A., Pretoria, An Old Dutch Grape Farm Cape Colony, Johannesburg, Fruit and vegetable farming - Canada, Our Brave Merchant Service, the third included: Bettws-y-Coed, Scenes in Devon, Derbyshire Peak District, Picturesque Spots in North Wales, The Wye Valley, Coaching round Keswick, Noble Ruins of the Monk Days (Abbeys), Waterfalls of the North Country.

The list shows that the Cinematographic Branch looked quite desperately for interesting material, presenting the British Empire as global, industrious, fertile mosaic of scenic landscapes and landmarks of architecture and science. This approach might have been quite successful by a nation widely interested in modern technic, eager to watch remote landscapes and exotic cultures. In the war years cinema audience yearned for the pre-war travelogues, as results for instance from the afore mentioned popularity of Italian war propaganda, which focused on the scenic Alpine landscapes. The continuity was also a key word: in a time 
of global insecurity a constant flux of pictures, related even if only loosely to each other, brought a promise of continuity. Seriality was a key to success, not only in feature films (especially in thrilling series, each episode of which ended usually with the cliff-hanger, popularized by American series The Perils of Pauline, 1914), but also in industrial films. While shown in sections, they also brought the promise of continuity, of ongoing, stable production and of world unshaken by the war (Jung and Mühl-Benninghausen 430).

In a longer run, however, the decision to ignore Maxse's suggestion about film adaptations of classical British novels was not a fortunate one, compared to the successes of German, French, Italian and Danish film adaptations which flooded Dutch screens throughout the war years. The Foreign Office argued that it appeared to be "doubtful how far a Government Department is justified in spending public money in purchasing films which can only very remotely be said to have a Propagandist value" (FO 395/102/213171, Guest's Memorandum, 1 November 1917). Instead London was ready to dispatch to the Netherlands following titles: Chinese Labour Contingent in France, South African Labour Contingent, The United States Troops Marching through London, German Prisoners at Donington Hall, Portuguese Expeditionary Force in France, The Storm and the Drifters, The Egyptian Labour Contingent. One can only guess the difficulties such titles had to face to bypass Dutch censorship restrictions and to attract Dutch neutral and increasingly anti-British public. Still, London insisted not only on screening of such titles but also on making the screenings profitable, also in economic sense.

\section{Conclusion}

From the British documents it can be inferred that neither the War Office Cinema Committee nor the Ministry of Information were willing to invest great amounts of money and work into development of a system of secondary propaganda, while at the same time in Germany emerged. Presumably, for British propaganda officers in London the Dutch territories were of secondary importance. The efforts of Ernest Maxse and George F. Steward appear not backed enough from London, the collaboration between British officers in Rotterdam, The Hague and London - not entirely free from personal ambitions, and therefore leading to some basic errors, as the delay in delivery of The Battle of Ancre, which proved disastrous for British propaganda (FO 395/102/196650, Steward to Maxse, 3 October 1917).

From the summer of 1916 the attention gradually shifted towards Dutch colonies, firstly the West, then in 1917 the East Indies. In both cases, British film propaganda proved futile. In West Indies it lost to the underdeveloped scheme of distribution, the territorial span of Antilles and Dutch Guyana, and opposition of the German minority among white settlers (FO 395/102/38/171180, Gowers to Lampson, 26 August 1916; FO 395/102/204071, Pryde Hughes to Montgomery, 18 October 
1917, 26 August 1917, FO 395/102/222554, Rothwell to Montgomery, 19 November 1917). In Dutch East Indies, British films had not only to struggle against Dutch policy of neutrality, perils of the sea trade, and German opposition, but also against French competition. The French managed to use the American branch of Pathé, to distribute their propaganda through commercial network spanning throughout the Archipelago (Thompson 44). French Pathé's war journals reached the colony quite regularly, as did some of the French feature-length propaganda films, as results from numerous adverts and articles in local newspapers from that period (delpher.nl).

The British strategy of influencing Dutch audiences in Europe and in the colonies via the medium of film proved futile. The very plausible influence of Britain Prepared on Dutch propaganda film remained unresearched for almost a century. There is an open field for speculations why the British ignored entirely the existing connections between the British and Dutch film industries. Neither was Charles Urban, linked to Dutch film making from its very beginnings, involved in promoting his own film, nor did the British propaganda play upon the existing connections between Frenkel, Nöggerath, or Binger with British film industry. Although Nöggerath's memories Chapters From the Life of a Camera-Operator, describing his British period, were published from 15 February 1918 to 3 January 1919 in the Dutch cinema magazine De Kintopp (Blom 1999, 263), there is no hint that the British were anyhow involved in the publication. Similarly, the recollections of Theo Frenkel Sr., once a close collaborator of Urban and Hepworth, published in several instalments in the openly pro-British newspaper De Telegraaf in 1917, were most probably neither inspired nor used by British propaganda officers.

British-Dutch film cooperation did not cease to exist throughout the war and it blossomed shortly after the conflict had ceased. In August 1919 experienced Dutch film maker Maurits Binger joined forces with British distributor Harry R. Smith and director B.E. Doxat-Pratt (Bishoff 82, Delpeut 21). Anglo-Hollandia, renamed in 1920 Granger-Binger Film made some relatively successful films. Binger, however, worked for a British distributor The Central Feature \& Exclusive Film Co., Ltd already in 1915 (eyefilm.nl). The film starred Fred Penley, a British internee, who established the cabaret Timbertown Follies at the Groningen (POW) Camp and found a way into Dutch film (see Timbertown Follies 2014). The Penley-case, and the phenomenon of the war-time British cabaret, was also only recently researched (see Wielinga 2014). It is highly plausible that British authorities had no knowledge of commercial cooperation between the Dutch and the British that ran despite the turbulences throughout the conflict.

The question that arises is whether this knowledge would have changed anything in British propaganda strategy. Even if the turn towards secondary and covert propaganda had occurred earlier, probably it would not have changed the situation much. It appears not very plausible that even perfect propaganda features would have changed the Dutch mistrust and antipathy towards Great Britain after trade restrictions, annexation of ships, cutting off the cable connecting the country 
with its colonies etc. The genius of D. W. Griffith would probably have proved futile after the Dutch-British tensions caused by discontinuation, under British pressure, of re-selling imported goods to Germany.

Another important fact is that the Netherlands remained in many aspects quite marginal for British propaganda politics. The British aimed at convincing the USA to join the war, and at counterbalancing German propaganda, rather than at putting in every possible effort to win hearts and minds of the Dutch people. Regardless of their crucial geopolitical position, Dutch territories in Europe, Asia Pacific and Southern America, were not the main concern of the British. The Cinematographic Branch was interested in influencing Dutch audiences but, unlike the Germans, not willing to make any special efforts of financial or creative kind. Therefore, it is rather plausible that even if the British were aware of the range of bilateral contacts within the film trade, they would not have invested much in making pro-British propaganda by Dutch directors and producers. Such strategy reached beyond the principles and the plans of British film propaganda at that time.

The historical conclusion appears to be quite clear: British film propaganda achieved successes in the Netherlands, but its most spectacular success, Britain Prepared seems to have been overshadowed by the problematic case of The Battle of the Somme misinterpreted by Dutch spectators and ridiculed by Dutch peace organization, the NAOR. The militaristic character of the Somme-film discredited all further British feature-length war documentaries and reduced their impact to the closed circle of trusted sympathizers of the British case. Unwilling to invest in book adaptations or impressive historical melodramas, the Cinema Branch tried to achieve success with documentary shorts of marginal meaning and questionable artistic value. Therefore, the triumph of German secondary film propaganda, carefully orchestrated and abundantly financed by the Ufa, came as no surprise.

On the other hand, "[t]he belligerents' general disregard for the sanctity of international laws that govern neutrality" (Abbenhuis 262), did not facilitate the work of propaganda officers. They had to face the hostile attitude towards British militarism and imperialism, which affected the Netherlands not only in political terms but far more through economic restrictions affecting the daily life of nearly all Dutchmen. "The neutral's ultimate purpose was to stay out of the war. In the end, the loss of sovereignty, independence and economic security - three things that the Dutch had hoped to achieve by staying neutral - were price paid for fulfilment of the general aim" (Abbenhuis 263). The British played too prominent a role in the process of stripping the Netherlands of its core values to be able to win hearts and minds of the Dutch by means of propaganda, I will conclude. The disregard of Dutch sense of integrity appears to have been more detrimental to British propaganda that the lack of knowledge of commercial and artistic links between Dutch and British commercial film. However, they both appear to be rooted in the same approach of neglect and lack of respect for a small nation, representing other set of values than the militant British one. 


\section{References}

Aarten, Stephanie Sierou. 2015. Holland Neutraal: Een onderzoek naar de totstandkoming, receptie en vertoning van de Nederlandse leger en vloot film gedurende de eerste wereldoorlog, aan de hand van kranten, opiniebladen, en filmvakbladen. Unpublished MA. Brussel: VUB.

Abbenhuis, Maartje. 2006. The Art of Staying Neutral. The Netherlands in the First World War, 1914-1918. Amsterdam: Amsterdam University Press.

Abel, Richard. 1991. "French Film Melodrama: Before and After the War." Imitations of Life: A Reader on Film \& Television Melodrama. Ed. Marcia Landy Detroit: Wayne State University Press. 542-568.

Badsey, Setephen. 2009. The British Army in Battle and Its Image 1914-18. London: Continuum.

"Wat leert ons de Leger- en Vlootfilm?" Bataviaasch nieuwsblad (6 February 1918): 2.

Bishoff. Ruud. 1986. "De zwijgende speelfilm." Geschiedenis van de Nederlandse film en bioscoop tot 1940. Ed. Karel Dibbets and Frank van der Maden. Weesp: Het Wereldvenster. 53-104.

- 1988. Hollywood in Holland. De geschiedenis van de Filmfabriek Hollandia 1912-1923. Amsterdam: Thoth.

Blom, Ivo. 1996 "Of Artists and Tourists. Locating Holland in Two Early German Films." A Second Life: German Cinema's First Decades. Ed. Thomas Elsaesser and Michael Wedel. Amsterdam: Amsterdam University Press. 246-255.

-. 1997. "De eerste filmgigant in Nederland. De snelle verovering van Nederland door Pathé." Jaarboek Mediageschiedenis 8: 129-152.

-. 1999. "Chapters from the Life of a Camera Operator. The recollections of Anton Nöggerath - filming news and non-fiction, 1897-1908. " Film History 11. 3: 262-281.

—. 2001. "Business as usual? Filmhandel, bioscoopwezen en filmpropaganda in Nederland tijdens de Eerste Wereldoorlog." Leven naast de catastrofe. Nederland tijdens de Eerste Wereldoorlog. Ed. Hans Binneveld, Martin Kraaijestein, Marja Roholl, and Paul Schulten. Hilversum: Verloren. 129-143.

-. 2003. Jean Desmet and the Early Dutch Film Trade. Amsterdam: Amsterdam University Press.

Buelens, Geert. 2010. "The Silence of the Somme. Sound and Realism in British and Dutch Poems Mediating The Battle of the Somme." Journal of Dutch Literature 1. 1: 5-27.

-. 2016. "Inleiding." Plots hel werd het. Jacobus van Looy en The Battle of the Somme. Ed. Geert Buelens. Rimburg: Huis Clos. 9-14.

Carden, Ron. 2014. German Policy Toward Neutral Spain, 1914-1918. London and New York: Routledge. 
Compagnon, Olivier and Pierre Purseigle. 2016. "Géographies de la mobilisation et territoires de la belligérance durant la Première Guerre mondiale." Annales. Histoire, Sciences Sociales (71e année): 37-64.

Conrad, Sebastian and Shalini Randeria. 2002. Jenseits des Eurozentrismus: postkoloniale Perspektiven in den Geschichts- und Kulturwissenschaften. Frankfurt and New York: Campus Verlag.

Convents. Guido. 2000. Van kinetoscoop tot café-ciné: de eerste jaren van de film in België, 1894-1908. Leuven: Universitaire Pers.

Cürlis, Hans. 1918. "Aufzeichnungen und Vorschläge in Filmsachen anlässlich einer Reise nach Holland." Bundesarchiv Berlin Lichterfelde R901/ 71961.

Delpeut. Peter. 1997. "A Cinema of Accidental Incidents. Dutch Fiction Films 1896-1933. A Review." Of Joy and Sorrow: a Filmography of Dutch Silent Fiction. Ed. Geoffrey Donaldson. Amsterdam: Stichting Nederlands Filmmuseum. 11-32.

Dibbets, Karel and Wouter Groot. 2010. "Which Battle of the Somme? War and Neutrality in Dutch Cinemas, 1914-1918." Film History 22: 440-452.

Dijk, Kees van. 2007. The Netherlands Indies and the Great War. Leiden: KITLV Press.

Duisberg, Carl Ludwig. 2001. "Revolution der Filmkunst. Gedanken ueber die Macht des Films (1917)." KINtop. Jahrbuch zur Erforschung des frühen Films. KINtop-Jahrbuch 10: Europäer in den USA. 95-102.

Engelen, Leen. 2005. "Cinematic Representations of the Enemy in Belgian Silent Fiction Films." Warfare and Belligerence. Perspectives in First World War Studies. Ed. Pierre Purseigle. Boston: Brill. 359-378.

Espagne, Michel. 1994. "Sur les limites du comparatisme en histoire culturelle." Genèses 17: 112-121.

Frey, Marc 2000. "The Neutrals and World War One." Forsvarsstudier 3: 4-39.

—. 2001. "Anglo-Dutch Relations during the First World War." Unspoken Allies: Anglo-Dutch relations since 1780. Ed. Nigel Ashton and Duco Hellema. Amsterdam: Amsterdam University Press. 59-84.

Haan, Jitze de. 1995. Polygoon spaant de kroon. Geschiedenis van filmfabriek Polygoon 1919-1945. Amsterdam: Otto Cramwinckel.

Jung, Uli and Wolfgang Mühl-Benninghausen. 2005. "Ästhetischer Wandel. Dokumentarische Propagandafilme." Geschichte des dokumentarischen Films in Deutschland. Vol. 1: Kaiserreich 1895-1918. Ed. Uli Jung and Martin Loiperdinger. Stuttgart: Reclam. 429-453.

"Fred Penley." https://www.eyefilm.nl/collectie/filmgeschiedenis/persoon/fredpenley

Jeffery, Keith. 2010. MI6: The History of the Secret Intelligence Service 1909-1949. London: Bloomsbury Press.

Klinkert, Wim. 2013a. Defending Neutrality: The Netherlands Prepares for War, 1900-1925. Leiden-Boston: Brill. 
—. 2013b. "A Spy's Paradise? German Espionage in the Netherlands, 1914-1918." Journal of Intelligence History 12. 1: 21-35. http://dx.doi.org/10.1080/1616 1262.2013.755017

Kristel, Conny. 2007. "Propagandaslag. Nederlandse reacties op de Britse film 'Battle of the Somme' (1916)." Wankel evenwicht. Neutraal Nederland en de Eerste Wereldoorlog. Ed. Martin Kraaijestein and Paul Schutten. Soesterberg: Aspekt. 344-365.

—. 2016. De oorlog van anderen: Nederland en oorlogsgeweld, 1914-1918. Amsterdam: De Bezige Bij.

Kruizinga, Samuel. 2012. Overlegeconomie in oorlogstijd: de Nederlandsche Overzee Trustmaatschappij en de Eerste Wereldoorlog. Zutphen: Walburg Pers.

"Kunst en Letteren. Cinema Palace. Oorlogsfilms." Het Volk (28 November 1916): 6. LEO. "Cinema Palace. De slag aan de Somme. De verovering van Gorizia." De Telegraaf (28 November 1916): 6.

Maden, Frank van der. 1986. "De komst van de film." Geschiedenis van de Nederlandse film en bioscoop tot 1940. Ed. Karel Dibbets and Frank van der Maden. Weesp: Het Wereldvenster. 11-52.

McEwen, J. M. 1979. "Lord Beaverbrook: Historian Extraordinary." Dalhousie Review 59. 1: 129-143.

McKernan, Luke. 2013. Charles Urban: Pioneering the Non-Fiction Film in Britain and America, 1897-1925. Exeter: University of Exeter Press.

McKernan, Luke. 2002. "Propaganda, Patriotism and Profit: Charles Urban and British Official War Films in America during the First World War." Film History 14 nos. 3-4.

Messinger, Gary S. 1993. "An Inheritance Worth Remembering: The British Approach to Official Propaganda During the First World War." Historical Journal of Film, Radio and Television 13: 117-128.

Moeyes, Paul. 2001. Buiten Schot: Nederland tijdens de Eerste Wereldoorlog 1914-1918. Amsterdam: de Arbeiderspers.

"Papers of Sir Francis Oppenheimer (1870-1961)." Balliol College Archives \& Manuscripts. http://archives.balliol.ox.ac.uk/Modern\%20Papers/oppenheimer.asp

Pfister, Manfred. 2008. "Introduction: Performing National Identity.." Performing National Identity: Anglo-Italian Cultural Transactions. Ed. Manfred Pfister and Ralf Hertel. Amsterdam and New York: Rodopi. 9-28.

Ponsonby, Arthur. 1928. Falsehood in War-Time: Containing an Assortment of Lies Circulated Throughout the Nations During the Great War. London: Garland Publishing Company. http://gutenberg.net.au/ebooks10/1000011.txt

Reeves, Nicolas. 1983. "Film Propaganda and its Audience: The Example of Britain's Official Films during the First World War." Journal of Contemporary History 18: 463-494. 
Reeves, Nicholas. 1986. Official British Film Propaganda During the First World War. London: Croom Helm.

Reeves, Nicholas. 2003 [1999]. The Power of Film Propaganda: Myth or Reality. London: Continuum.

Reiter. Don. 1996. Crucible of Beliefs: Learning, Alliances, and World Wars. Ithaca-London: Cornell University Press.

Rogin, Michael. 1985. “The Sword Became a Flashing Vision': D. W. Griffiths The Birth of a Nation." Representations, Special Issue: American Culture Between the Civil War and World War I 9: 150-195.

Rossini, Manuela and Michael Toggweiler. 2014. "Cultural Transfer: An Introduction." Word and Text. A Journal of Literary Studies and Linguistics 4. 2: 5-9.

Ruis, Edwin. 2016. Spynest: British and German Espionage from Neutral Holland 1914-1918. Stroud: The History Press.

Sanders, M. L. 1975. "Wellington House and British propaganda during the First World War." The Historical Journal 18: 119-146.

Smither, Roger. 2005. "Der Magische Gurtel (The Enchanted Circle, 1917) A Case Study in First World War German Propaganda." War and the Media: Reportage and Propaganda 1900-2003. Ed. Mark Connelly and David Welsh. London: I.B. Tauris. 82-91.

Stiasny, Philip. 2009. Das Kino und der Krieg. Deutschland 1914-1929. München: edition text + kritik.

Tames, Ismee. 2006. Oorlog voor onze gedachten. Oorlog, neutraliteit en identiteit in het Nederlandse publieke debat, 1914-1918. Hilversum: Verloren.

Taylor, Philp M. 2003 [1990]. Munitions of the Mind: A History of Propaganda from the Ancient World to the Present Era. Manchester: Manchester University Press.

De Telegraaf (28 November 1916): 6.

Thompson, Kristin. 1985. Exporting Entertainment: America in the World Film Market 1907-1934. BFI: London.

Vaal, J. de, A. Grandia en H. Weijel. 1984. "Theo Frenkel Sr. Mentor van de Nederlandse Filmindustrie." Filmmuseum cinemateek journaal. 57. 1983-1984: $19-22$.

Het Volk (28 November 1916).

Vries, Tjitte de en Ati Mul. 2009. "They thought it was a Marvel." Arthur Melbourne-Cooper (1874-1961) Pioneer of Puppet Animation. Amsterdam: Amsterdam University Press/Pallas Publications.

"Wat leert ons de Leger- en Vlootfilm? Bataviaasch nieuwsblad (6 February 1918): 2. Werner, Michael and Bénédicte Zimmermann. 2003. "Penser l'histoire croisée: Entre empirie et réflexivité." Annales. Histoire, Sciences Sociales. 2003/1 (58e année): 7-36.

West, Nigel. 2013. Historical Dictionary of World War I Intelligence. Lanhan: Scarcecrow Press. 
Wielinga, Menno. 2014. Het Engelse Kamp Groningen 1914-1918. De geschiedenis van 1.500 Engelse militairen tijdens de Eerste Wereldoorlog. Bedum: Profiel Uitgeverij.

Willems. Wim. 2004. Cultuur en migratie in Nederland. De kunst van het overleven. Levensverhalen uit de twintigste eeuw. Den Haag: Sdu Uitgevers.

Zwaan, Klaas de. 2016. "De dood op het doek. The Battle of the Somme als mediagebeurtenis in Nederland." Plots hel werd het. Jacobus van Looy en The Battle of the Somme. Ed. Geert Buelens. Rimburg: Huis Clos. 69-86.

\section{Archival sources}

Foreign Office, INF 4/4A.

FO 395/22/231749, 30 October 1916, Blakiston to Carson.

FO 395/38/171180, Gowers to Lampson, 26 August 1917.

FO 395/100/174949, Steward to Maxse, 28 August 1917.

FO 395/102/214539, Maxse to Montgomery, 8 January 1917.

FO 395/102/12446, Johnstone to Maxse, 9 January 1917.

FO 395/102/12077, Wicks to Carson, 16 January 1917.

FO 395/102/31076/Johnstone to Montgomery, 5 February 1917.

FO 395/102/154058, Maxse to Montgomery, 4 August 1917.

FO 395/102/196650, Steward to Maxse, 3 October 1917.

FO 395/102/204071, Pryde Hughes to Montgomery, 18 October 1917.

FO 395/102/206901, Northam to Montgomery, 27 October 1917.

FO 395/102/213171, Guest's Memorandum, 1 November 1917.

FO 395/102/223309, Stewa rd to Maxse, 14 November 1917.

FO 395/102/222554, Rothwell to Montgomery, 19 November 1917.

FO 395/102/222558, Brunel to Montgomery, 20 November 1917.

FO 395/102/242413, Gilmour to Steward, 20 December 1917.

FO 395/102/238426, Steward's Report, December 1917.

Bundersarchiv R901/71951, German Embassy to Foreign Office, 25 October 1917.

Bundesarchiv R901/71961, NOT to Firma B. Vissers, 17 September 1918.

\section{Filmography}

Alsace. 1916. Dir. Henri Pouctal. Prod. Le Film d'Art.

L'Alsace attendait 1917. Dir. Henri Desfontaines. Prod. SPCA.

The Battle of Arras 1917. Dir. unknown. Prod. Topical Films Committee, William Jury. Geoffrey H. Malins.

The Battle of the Ancre and the Advancement of Tanks [The Battle of the Scarpe]

1917. Dir. Geoffrey H. Malins. Prod. WOCC, William Jury. 
The Battle of the Somme 1916. Dir. Geoffrey Malins and John McDowell. Prod. William Jury.

The Battle of Waterloo 1913. Dir. Charles Weston. Prod. British \& Colonial Kinematograph Company.

Bei unseren Helden an der Somme. 1917. Dir. unknown. Prod. Bufa.

Britain Prepared.1915. Dir. Charles Urban. Prod. Charles Urban.

Called to the Front. 1914. Dir. Charles Weston. Prod. Regent Film.

General Allenby's Entry into Jerusalem [General Allenby Enters into Jerusalem].

1918. Prod. WOCC, Topical Budget Films.

Hearts of the World. 1918. Dir. D.W. Griffith. Prod. D.W. Griffith, WOCC.

His Britannic Majesty's Visit to His Grand Fleet [His Majesty's Visit to His Grand

Fleet or The King's Visit to His Grand Fleet]. 1917. Dir. unknown. Prod. WOCC.

Mater Dolorosa. 1917. Dir. Abel Gance. Prod. Louis Nalpas.

Mères françaises. 1917. Dir. René Hervil, Louis Mercanton. Prod. Éclair.

The National Film. 1918. Dir. D.W. Griffith. Prod. D.W. Griffith, WOCC.

The Perils of Pauline. 1914. Dir. Louis J. Gasnier, Donald MacKenzie. Prod. Pathé

Frères.

Peronne [The Great German Retreat. The Capture of Peronne]. 1917. Dir. William

Jury, Geoffrey Malins, J. B. MCDowell, H. C. Raymond. Prod. WOCC and Topical Film Company.

Pimple's Battle of Waterloo (1913). Dir. Fred Evans, Joe Evans. Prod. Folly Films. Portuguese Expeditionary Force in France [The Portugese Contingent]. 1917. Dir. unknown. Prod. WOCC and Topical Film Company.

La Presa di Gorizia [La battaglia di Gorizia]. 1916. Dir. Luca Comerio. Prod. Luca Comerio.

La Puissance militaire de la France. 1917. Dir. Henri Desfontaines. Prod. Section Cinématographique des Armées (SCA)

The Road to Calais. 1914. Dir. Charles Weston. Prod. Regent Film.

Sons of [our] Empire. Dir. William Jury, J. B. McDowell, H. C. Raymond. Prod. WOCC and Topical Film Company. 1917.

The South African Labour Contingent in France [South African Labour Contingent

Somewhere in France]. 1917. Dir. unknown. Prod. WOCC and Topical Film Company.

Storm and the Drifters [The Story of the Drifters and of the Sea Dogs who man them, The or The Story of the Drifters and of the Sailors who man them ]. 1917.

Dir. F.W. Engholm. Prod. Admiralty.

A Study in Scarlet 1914. Dir. George Pearson. Prod. George Pearson.

The Timbertown Follies 2014. Dir. Leo van Maaren. Prod. Stichting Jazz van het Bankroet.

Tommy Atkins. 1915. Dir. Bert Haldane. Prod. Barker.

Ultus and the Secret of the Night. 1916. Dir. George Pearson. Prod. Gaumont GB. 
Ultus and the three-button mystery. 1917. Dir. George Pearson. Prod. Gaumont GB. Ultus, the Man from the Dead. 1916. Dir. George Pearson. Prod. Gaumont GB. The Valley of Fear. 1916. Dir. George Pearson. Prod. G. B. Samuelson Productions. 

Anne Samson

(iD https://orcid.org/0000-0002-9608-8152

independent scholar and co-ordinator of the Great War in Africa Association

\title{
The End of the 1914-1918 War in Africa
}

\begin{abstract}
The end of the First World War in Africa occurred at different times across the continent as the German colonies capitulated and surrendered to the allied forces between 26 August 1914 and 25 November 1918. The experience of each territory was indicative of its colonial development and local conditions. As the war inched across the landscape so people moved between states of peace and conflict, all caught up in some aspect either directly or through the provision of food and other materials. This chapter explores different experiences across the continent and the legacy of the discussions at Versailles.
\end{abstract}

\section{Africa: After the Armistice}

In contrast to the war in Europe, the war in Africa staggered to an end. The Armistice agreement which led to the ceasefire on 11 November 1918 made provision for a ceasefire in Africa within a month. This was because the powers in Europe were unclear about where their forces in East Africa actually were. As it turned out, the first attempt at alerting the German forces to the surrender took place on 13 November after the battle of Kasama. Five days later the Germans accepted the fact that they were to lay down their arms, which they formally did on 25 November 1918 in Abercorn, Northern Rhodesia (Mbala, Zambia).

The length and reach of the campaign in East Africa makes it easy to forget that other African regions were also caught up in the war. The state of flux in territories where fighting had ended before the war in Europe - Togoland, Cameroon and South West Africa - brought its own frustrations and challenges to both the inhabitants and the interim overseers as they waited for the Imperial powers to determine the fate of the loser and its subordinate territories. The East Africa campaign was affected by each of the other territories declaring peace. It therefore seems appropriate to look briefly at the end of the war for each of these territories: Togoland, South West Africa, and Cameroon. Not to be forgotten is Egypt, which although a major centre for troops fighting in Gallipoli and travelling through the Suez Canal, saw its own local struggle particularly against the Senusi. This latter was an ongoing struggle which in effect continued until 1921. 
The first territory to declare peace in Africa was Togoland on 26 August 1914. The German commander saw little reason for the country or peoples to go through the pains of war when he knew his force would be overpowered by the joint British and French contingents. When the Acting German Governor HansGeorg von Döring offered terms of neutrality to the Allied Forces, the British refused and demanded full surrender within 24 hours. In response, the Germans withdrew from Lomé to make a final half-hearted stand outside Kamina, where the international radio station was, before surrendering on 26 August.

The surrender of Togoland allowed the British and French forces along with support from the Belgians in the Congo to focus on German Cameroon. Following a tough struggle there, mainly as a result of the terrain and climate, the Germans, 155 men, under Captain Ernst von Raben surrendered on 18 February 1916 at Mora.

Prior to the defeat of Cameroon and further south, the South Africans brought the Germans in South West Africa, under the command of Erich Victor Carl August Franke and Governor Theodore Seitz, to surrender on 9 July 1915. The conclusion of the campaign in South West Africa enabled the British government to relaunch the stagnant campaign in East Africa, when the South African Union government offered to send 10,000 men to the territory. They arrived in early 1916 while, later in the year, contingents from West Africa and the West Indies, having defeated the Germans in Cameroon were able to join the fray in East Africa. This resulted in a diverse fighting force in the area -177 micro-nations from across 23 countries participated in the conflict which finally ended on 25 November 1918.

The nature of the conflict in the African territories, and in East Africa particularly, meant that different regions experienced peace before others. In East Africa, the first significant date was March 1916 when the British allied forces moved into German East Africa. This removed the direct threat to British East Africa (Kenya) and the colony was able to return to some sort of normality whilst remaining a military base or centre. The second date was 24 November 1917 when the German forces left German East Africa and moved across the Rovuma River into Portuguese East Africa. General Jan Christian Smuts, Commanding Officer of the British Allied forces, believed the campaign to be over, except for mopping up operations and introduced civil administration to the German territory on 11 December 1916. This caused problems for the administrator, Horace A Byatt, when the Germans re-entered their territory on 28 September 1918 turning it back into a war zone. The Germans did not stay long as they moved into Nyasaland and Northern Rhodesia where they surrendered two months later.

This article will explore the final days of the war in Africa, for each of the territories which surrendered early, and for East Africa from 11 November through to the departure of the Germans on 19 February 1919. The discussions at Versailles will be considered in light of the final 'scramble for Africa' as well as the repercussions of these talks. In addition to the primary and secondary sources available, fictional accounts are used to understand how the communities 
adjusted to peace and their emotional reactions to the end of the conflicts which started with the first shots in Togoland on 7 August 1914 followed a day later by the bombing of Dar es Salaam in German East Africa on 8 August. Four years separated the first and last surrenders suggesting a chronological and regional approach to the topic while emphasising that Africa is not a homogenous whole and should not be treated as such. In addition, this approach highlights the imbalance of treatment across the continent by both fiction and non-fiction writers of the First World War in Africa.

\section{Searching for the Local Voice}

Recent commentators have criticised the bias of articles and books for being white dominated with minimal focus on the black African voice and that little, if anything, has emanated from African authors. While in many respects this criticism is valid, the position is changing as researchers are becoming aware of more localised accounts and memoirs as well as an increased interest in the campaigns in Africa. Numerous historians and scholars of other disciplines working on aspects of the war in Africa find it difficult to get their voice heard outside of Africa and where authors are heard, their academic training has been such that the European perspective dominates. ${ }^{1}$ Africa consists of diverse cultures each with its own truth of the past expressed in different ways. For many cultures in Africa, the oral tradition dominated and according to westernised standards, literacy was restricted. The reasons for this are outside the scope of this chapter, but the impact directly concerns it: There are very few accessible sources containing the local voice and as these were not sufficiently valued at the time to record, local accounts and memories of the Great War in Africa have been largely supressed.

The memory and significance of those who lost their lives in the First World War in particular appears to have little meaning for many local populations although most Commonwealth countries have a service on 11 November to remember those who gave their lives in the conflict. In contrast, amongst peoples of African descent in Europe and America there seems to be a growing interest in what happened during the years 1914-1918 and the impact the conflict had in the post-war years as witnessed in the number of British Heritage Lottery Fund applications and social media interactions. This divide has been highlighted by the centenary commemorations of the Great War demonstrating an apparent lack of interest through the low number of special commemorative events in Africa (Hastings). In 2014, an event in Tsavo, Kenya marked the first shots of the war in East Africa on 15 August 1914, in 2017 Egypt held what appears to be its first commemorative event of the war and in 2018 both Kenya and Zambia will be holding remembrance events to mark the end of the war. Interestingly, in 2014 Nigeria moved its service to remember the country's "fallen heroes" from 11 November to 15 January, 
the date the civil war ended in 1970 (CFCP Nigeria). There does not appear to have been another that year to mark the outbreak of what became the Great War and although the 1914-1918 war is mentioned in the literature of the event, it clearly plays a minor role. In addition, a recent perusal of documents on Sierra Leone in the Commonwealth War Grave Commission Archive indicated that in the 1950s the war graves were in a poor state as people going to bury their dead walked over the grave stones in the CWGC section. More recent photos of CWGC cemeteries in Nairobi show how shanty towns were encroaching on the sites supported by a local petition to safeguard the remaining cemeteries (Change.org).

The absence of local voices has been obvious in centenary-focused community-led projects in the United Kingdom where project managers have complained about the lack of engagement by Africans in Africa around the Great War; a point evidenced in the paucity of fiction around the events of 1914-1918. One of the reasons for the shortage of literature is the fact that African literature as a genre only started to develop from the 1950s as the independence struggles became more vociferous. Significantly, Joseph Lon in his discussion on the role of memorials notes "that the sustainability of monuments and historical sites depend on the values attached to them and the historical importance or popularity of the events they represent" (8). The lack of fictional and even first-hand accounts can be attributed to the low value, historical importance and popularity of the Great War in Africa.

Before looking at each of the territories concerned, it might be helpful to consider the context of World War One commemorations in and around Africa through the available literature - fiction and non-fiction. For reasons of language, this will be limited to texts dealing with the British Empire although where known other languages will be included.

'Africa is a country' is a phrase regularly bandied about today and a search on the Internet will provide a list of senior politicians, including United States of America presidents, referring to the 53 countries as one entity. In fairness, Africans although aware of the diversity of the continent will often refer to it as though it is one country too - a product of the international media. Since 2014, the centenary year of the outbreak of World War One, there has been a slow growth of interest in the war in Africa with many expecting to find the same level and type of information available as there is for the British Western Front. The shock at not finding this information has led to accusations of racism, colonialism and demands for the history to be 'decolonised.' These claims in themselves fail to recognise the diversity of the African continent (Williams).

On the positive side, however, opportunities have arisen through increased awareness of, and engagement with, the First World War in Africa to allow the diversity to be explored. For the purposes of this discussion, this chapter divides Africa into four sections, recognising that by doing so it is treating numerous territories as one. However, the move is justified for reasons of space and coherence, especially as each zone tends to have a regional dominant character. 
North Africa to start, is generally regarded as the area north of the Sahara Desert along the coast of the Mediterranean. It is predominantly French, Muslim and Arab. During the war, Egypt was used as a base for troops on route between India, Gallipoli, Australia and Europe. It has therefore generally been treated as an extension of the European war. However, as noted later in this chapter, there was local conflict against the Senusi and local mobilisation. Egypt, today's Ethiopia, Eritrea and Sudan, all need more research conducted into their involvement in the war and should, in contrast to current mainstream practice, be considered as part of the African continent. The press release issued by the Egyptian State Information Service on the 12 November 2017 service to commemorate the 103rd anniversary of the First World War provides evidence of the challenge to locate the local voice in a dominant narrative:

The Armed Forces celebrated on Sunday 12/11/2017 the 103rd anniversary of their participation in the World War I that was marked by heroic actions in defense of humanitarian principles.

Lt. General Reda Fadel, the head of the Armed Forces-affiliate military research authority, delivered the inaugural speech of the ceremony and expounded efforts of the authority in documenting Egypt's military history.

A documentary on Egypt's participation in WWI, among allied powers in Asia and Africa and the European front with 100,000 soldiers, was screened during the event.

The short film highlighted the heroism and sacrifices of Egyptian soldiers who received the Victoria Cross (VC) decoration, the highest award of the UK honors system.

The North West African territory which was French-dominated during the war requires similar treatment in terms of its African-ness - most attention currently being given to the forces who served in Europe, while the home fronts, at least in English texts are ignored. In terms of the centenary commemorations, the Europe-Africa divide is prevalent, although Algeria appears to break the mould based on conference and network announcements. Algerian academics are tapping into West African networks on the First World War, the zone which seems to be most active in researching the conflict. Parallels can be drawn with its greater political awareness, developments and links with the west.

Pan Africanism was strongest in West African countries in 1914 than elsewhere and this impacted the attitudes of different groups to involvement in the war; the coastal elites being more anti than the inland peasant farmers, the latter being more malleable by the colonial powers. Private correspondence and network announcements suggests there is engagement with World War One, however, for reasons set out at the beginning of this section, the findings are not reaching the wider academic or public world. 
Moving east and south, awareness of the war and the involvement of each of the territories is dependent on the prevalence of whites, ex-pat and settler, resident in the area. Of the East and Central African territories, awareness in Kenya is greater with Zimbabwe and Zambia following. Congo, controlled by Belgium during the war, has a developing local knowledge as Congolese academics are linking with colleagues in Brussels. Of the European powers, Belgium appears to be ahead in terms of remembering what happened on the African continent in 1914-1918. Zambia is becoming aware of its role in the war due to the centenary of the surrender in that country approaching. This has provided an opportunity for white Zambians to engage with the local black communities and the government to raise awareness of the country's contribution. The impact of white researchers taking time to engage with local communities and politicians has been witnessed in Tsavo, Kenya where for the centenary of the end of the war, local government has taken the lead, compared to the 2014 commemoration event being led and organised by the white Kenyan community (Guerrillas of Tsavo).

This leaves South Africa, a territory divided in its commemoration as it was with its war service. South Africa has remembrance around four events, each representative of the major cultural groups: the whites have Delville Wood commemorated on 11 November, the blacks Mendi Day on 21 February, the Coloured population recalls the Battle of Square Hill between 18 and 21 September 1918 and for the anti-Empire Afrikaner, there is Jopie Fourie who was executed as a traitor during the rebellion of 1914. Recollections of the Mendi have filtered into songs and mythology, this becoming the South African remembrance event in recent years. For the men of the Mendi whose war ended when their ship sank and they drowned, the story is recorded in a few books, the most recent being the 2017 novel, Dancing the Death Drill by Fred Khumalo. As with Britain, the Western Front dominates South African World War One literature, numerous non-fiction books being published by Ian Uys on the topic, Stuart Cloete and Wilbur Smith being the most well-known fiction writers. Wilbur Smith has three novels concerning the war in East Africa, none of which consider the event most closely associated with South Africa, namely the battle of Salaita Hill where approximately 600 white South African lives were lost (wounded and killed) on one day on 9 February 1916. The only novelist to consider this event is the American journalist Hamilton Wende who was resident in South Africa in 2005 when The King's Shilling: A Novel was published.

Memory and remembrance in Africa have traditionally been different to Europe, the demands of life and environment together with traditional beliefs seeing death as a natural part of life with the spirit of the individual being more important or significant than physical reminder, in other words, stories around the fire versus gravestones. Practices varied depending on whether missionaries or slavers had made inroads by the time of the war, the former leading to Christian education and Western burial practices, the latter to Islamic education and 
traditions. Scattered between, and often combining with external religious practices and beliefs were traditions. The fact too, that the First World War was, for many locals, seen as another war in a string of many again impacts on memory and commemoration. Those events we remember stood out and still do. If it did not strike one as significant at the time, it is not likely to be remembered in later years, unless resurrected for specific political purposes. At the time, 1919-1925, the need for so many to survive and rebuild their lives especially in places like Tanzania became paramount. The previously German colonies were learning to adapt to new rulers and administration. In South Africa, white nationalist agendas led to commemoration 'being swept under the carpet' and in West Africa, panAfricanism continued as the dominant rhetoric.

The above is not an excuse for ignoring the local voice, it is an attempt to understand why it is, and has been, silent. As will be seen in the discussion below, one or two accounts exist which are not Europe-centred. A change in focus from Europe-centred to one where Africa is the locus of events, will hopefully bring more local accounts to the fore, before they are lost forever. This chapter in discussing the end of the war in Africa aims to bridge the divide between the diversely ethnic local and European perspectives.

Impacting on the peace in each territory was the realisation that everything was in limbo until the war in Europe was won and the spoils divided. Although the British and French diplomats came to agreement during the war about what they wanted in Africa, they would have to wait for the ratification of all the powers involved (Samson 2005). At a local level, this provided a challenge to convince the local populations in previously German territories that their erstwhile-controllers had been defeated.

\section{Togoland}

Albert Calvert records his surprise at the way the Togolanders responded to the occupation by France and Britain after thirty years of "peaceful occupation and unprecedented progress in colonisation":

the ungrateful Togolanders [...] have welcomed [the Anglo-French troops'] triumphant entry into Lome with every demonstration of enthusiastic joy - "for days on end, in fullest gala attire, the population paraded the streets, singing and chanting songs of praise and thankfulness." (iix)

He expands on this with an extract from the Gold Coast Leader of 12 September 1914:

The surrender of Togoland has given rise to outbursts of joy and thankfulness among natives throughout the colony. In the Central and Western Provinces women, dressed in white, their wrists and necks encircled with white beads, and their necks and chests 
rubbed with white chalk, for days on end paraded the streets singing and chanting songs of praise and thankfulness for the victory of our soldiers. The terrible doings of Germans in Togoland [...] have become matters of common knowledge [...] and instinctively our people have felt that the loss of Togoland by the Germans is a distinct gain to the cause of the progress of natives and their good government throughout British West Africa. (83)

Calvert was motivated by a desire that Britain obtain the territory at the end of the war and set out to "present as completely and concisely as possible the material on which to base an estimate of the colonial and commercial value of this first fruits of the war that Germany thrust upon the Allies" (xxiv). In this he paints a picture of a territory having a wireless station, Kamina, "755 miles of road suitable for motor traffic" and rest houses in which only whites are allowed to stay. Surrounding the guest house was a "compound" consisting of between fifty and sixty round huts which were "sufficiently commodious to shelter a native family." There were rail links between Lomé and outlying regions such as Anecho, Palime, and Atakpame totalling 200 miles (5-6).

In giving the reader an openly biased account of the situation, Calvert has provided some insight into local reactions as depicted in the European-oriented media. ${ }^{2}$ Nearly one hundred years later, Benjamin Nicholas Lawrance recorded a similar feeling but noted that by the 1930s there was "widespread anti-British sentiment" due to the threat of direct taxes and a desire to return to the united German era pre-1914 (144). For the duration of the war in Europe, Togoland remained occupied by Britain and France, the area of the Ewe being administered by the British until 1919 when two-thirds of the country became part of the French mandate, splitting the Ewe community in half.

The Germans who were present in the colony became prisoners, the majority under British jurisdiction, although the German military commander was imprisoned in French West Africa for the remainder of the war. Britain shipped civilians to the United Kingdom before deporting them to Germany and allowed wives the option of joining their husbands imprisoned in Dahomey. Until 1916, German and Swiss missionaries were allowed to remain in the territory when they were sent to the Gold Coast. Mahon Murphy (45) records that 243 people were shipped to Britain during the war and 280 Germans were interned in Dahomey. Black soldiers who had fought for the Germans enlisted with the British forces serving in Cameroon and later East Africa (Ngung).

\section{Cameroon}

The surrender of Togoland allowed the allied naval and military forces in the area to unite and target Cameroon. Having successfully brought Cameroon to surrender on 18 February 1916, as in Togoland, the French and British continued to work 
together in a condominium. However, within a month of the German surrender, they had given up and on 4 March 1916 the conquered territory was split between France and Britain. The division was confirmed initially by an agreement signed in London in March 1916 and later the Versailles peace talks kept the territories separate until the independence of Southern Cameroon when the territories became united in name if not in substance; an issue still debated in 2014 (Dze-Ngwa 88). The Belgians who had supported the French against Cameroon had no part in the division of the territory, the involvement of the Force Publique being an offensive-defensive action. Congo's interest was the south bank of the Congo River which Portugal controlled and the occupation of German territory it would be able to use at the negotiating table in Europe, if needed. German East Africa was the only territory Belgium could consider fulfilling this aim.

The fall of Cameroon and the split agreed by the colonial powers broadly satisfied Britain and France which had reluctantly ceded the captured territory to Germany thirty-two years previously. For France, the additional land would help the country achieve its desire of a continuous stretch of French land from Algiers to Congo Brazzaville (Dze-Ngwa). By all accounts, Britain did not want huge amounts of land in West Africa, only territory, the equivalent of one-fifth, to round off the boundaries of its existing colonies of Nigeria and Gold Coast.

Across both sectors, French and British, "new languages, ideologies and systems of administration" were introduced (Dze-Ngwa, 83). These differed according to the occupying power and were not always welcomed or understood by the conquered. One of the terms of surrender was an amnesty for Cameroon Schutztruppe who had carried out instructions given by their German masters. However, according to British General Frederick Cunliffe, the French disregarded the clause and had executed a number of Cameroonians. This did little to help win support for the French. However, when Cameroonian subjects were to be returned during the war from German South West Africa where they appeared to be serving prison sentences, the French welcomed them back, even paying for their passage (Murphy 118).

The split in administration almost immediately gave rise to nationalist movements which worked towards unification - the pan-Kamerun Idea. The extent to which the pan-Kamerun Idea was based on nationalist ideals or a return to German colonial administration is questioned by authors. What is accepted, is the "sense of oneness among Cameroonians" which German colonial administration had created (Dze-Ngwa 84). The desire to be rid of colonial rule was apparent at the peace talks when a group led by Prince Alexander Ndoumbe Douala Manga Bell of Douala petitioned those meeting at Versailles to give "Cameroon for Cameroonians and Africa for Africans" (Dze-Ngwa 84). A similar movement began in the Congo under the Kibanguist movement led by Simon Kibangu from 1921.

As Kamerun capitulated, the German forces and their Schutztruppe fled into neighbouring Spanish Guinea where they were imprisoned on the island 
of Fernando Po. Here, outnumbering their jailers, the German officers began to plan their return to the mainland, until France and Britain threatened the King of Spain with reprisals. Nevertheless, the Beti leader, Karl Atangana, together with six other Beti leaders, remained loyal to the Germans and left with the officers for Spain. Having tried to lobby for a return of the territory to Germany at the peace talks through the intervention of the King of Spain, Atangana and his colleagues returned to French controlled Cameroun in 1920.

Despite the loyalty of Atangana and other chiefs, the Beti "spoke of horror of the First World War," they could not believe the extent of the destruction. In addition to the carnage, the war saw a breakdown in law and order, thefts, extortion and witchcraft increased with little traditional or colonial authority available to stem the tide. An American missionary noted that "former soldiers roamed freely about the countryside, raiding compounds, seizing women and looting goods" (Quinn 728) and others reported atrocities such as "Germans murdering unarmed civilians, mostly women, and children" (Ngung 307). Uncertainty in the area remained until France was guaranteed its control of the territory through the Versailles discussions.

The campaign accounted for 4,235 allied losses amongst soldiers and carriers either wounded or killed. Askari losses are estimated to be around 6,000 (Ngung) over the nineteen months of fighting. In contrast to some of the horror stories about German treatment, a month before the German forces surrendered, on 8 January 1916, the British commander in the Yaounde area, Gorges recorded that the enemy:

returned all our prisoners of war, amongst them being some British and French officers and civilians, native soldiers and a few non-combatants who had been taken by the Germans at various stages of the campaign. All had received fair and humane treatment during their capture. (Quinn 725)

In addition to these returned soldiers and non-combatants, Ngung (275) notes that "when Yaounde was taken, 255 askari men quickly deserted into the Allied African force, fifty per cent of whom brought in their arms and equipment." Insurrections and mutinies were regular occurrences leading to white officers becoming demoralised and capitulating. This appeared to be the outcome where askari had been conscripted, unlike the loyal Beti who joined voluntarily, before the war, accepting payments and promises of better times to come. The lack of discipline exercised by the soldiers led to large numbers of refugees fleeing into neighbouring territories, which in turn put pressure on the local economy and employment opportunities. 


\section{British West Africa}

In the countries which fought against the West African German colonies, the end of the fighting also had an impact. In the 1917 Annual Colonial Report on Nigeria, the Governor set out the economic impact in terms of imports and exports as well as taxes and other financial aspects, comparing current with pre-war and previous-year figures, splitting costs which were incurred as a result of the fighting from those which were associated with the general running of the territory. The need for people to focus on war-related work and join the army led to shortages which needed to be filled both during the fighting but more especially when peace was restored. For example, it was noted that 13 education staff in Nigeria had been involved in war work and between 1916 and 1917 there was a decrease in the number of secondary school pupils. Despite the number of police having been seconded to war work, discipline "was well maintained and the health of the force was generally satisfactory" (Colonial Report 14). However, in areas of sanitation distraction by the war led to increases in disease such as small-pox and yellow fever. "Material development" continued to be affected. The demands of the war meant that railway construction and public works programmes remained in abeyance (Colonial Report 24-25). Six mail steamers were lost during the war accounting for 67 lives, including four women, and "a large quantity of valuable Government stores which it was almost impossible to replace" (Colonial Report 25). Government was set back in its development of the country. The total cost of the war to 1916 excluding the East Africa campaign was $£ 358,700, £ 8,546$ being contributed in 1916. The cost of the Togoland campaign was estimated to be $£ 43,756$ for the Gold Coast (Colonial Report; Prempeh).

The end of the war in West Africa saw a continued drain on manpower for the British West African territories. During 1916, the Nigerian government sent 6,605 rank and file and 3,974 carriers to East Africa. Of the official staff, 112 had volunteered for service and the remaining staff absorbed the work of the third who were directly involved in war service: "Native Administration of the North had contributed a total of $£ 98,406$ up to the end of 1916 towards these war costs."

Despite the impact of the war and the challenges people were faced with, subscriptions to War Charities amounted to $£ 90,928$ of which $£ 49,546$ had been donated during 1916; $£ 4,000$ by Native Administration and the remainder was through private donation (Colonial Report 25). In Gold Coast, ten aeroplanes were purchased in support of the war effort along with over $£ 17,500$ raised for the Red Cross (Prempeh).

Governor Lord Lugard who signed the report on 12 November 1918 noted that the political situation was "progressive" whilst detailing arrangements that had been made with the chiefs in the Southern Provinces. In addition to insights which can be gleaned from official documents on the impact of the war, reports 
from missionaries and their experiences provide further valuable insight into the consequences of the conflict on local populations as well as political. The effect of Prophet Garrick Briade on the purchase of liquor between 1915 and 1918 corroborates the Colonial Report recording an unexplained significant decline in the purchase of alcohol and hence, government income (Prempeh xxi). The removal of civil servants from remote areas led local chiefs to believe the British were withdrawing with the result that lawlessness took hold as power vacuums developed with no neutral body to mediate.

The war had provided an opportunity for increased employment as men were sent to other countries for military and development work. Wartime wages were better. During 1918, 1,595 men enlisted into the Gold Coast military forces. On the conclusion of the war later that same year, the majority were demobilised to return home with money and increased independence. Some, on return, chose to challenge their chiefs (Prempeh 9). Some areas had to cope with increased numbers of refugees such as the Northern Provinces of the Gold Coast as men from the French colonies fled to avoid conscription. A total of 235 British West African lives were lost in Togoland and 562 in East Africa. This does not include those who returned home unable to work because of their war-induced injuries which had a serious impact on the economy as the men lost constituted the most able. The civil service was similarly affected by the loss of lives both due to military action and the loss of ships carrying personnel (Prempeh).

\section{South West Africa}

For all Togoland being the first German territory to capitulate during the war, it is South West Africa which is regarded as the first allied or British victory of the conflict. The reason is political: the commander of the South African forces and his deputy along with many others of the Union Defence Force had fought against the British Empire less than fourteen years before, and now, in 1915 had defeated the Germans who had promised the Boers their support all those years earlier. In addition to this victory, the same commander, General Louis Botha who was Prime Minister of the Union of South Africa, had put down a rebellion of his own people in the last months of 1914. Much was made in the British press about this quiet victory in the south of the African continent. Of the nine months in which the forces opposed each other, three were spent dealing with the South African rebellion whilst minor skirmishes took place in the German colony and the Germans took the opportunity to invade Portuguese Angola in the north, while in the remaining six months, only twenty-six days saw contact between the two sides. It was the nature of the terrain.

On 9 July 1915, the German Governor and his commanding officer agreed the unconditional surrender terms they were presented with. Governor Theodore 
Seitz had attempted various delay tactics but Louis Botha, following Lord Kitchener's actions in the Boer war of 1899-1902, held forces in readiness pending a breakdown in talks. This final surrender was to see an almost instant change in government. Although the Union was aware that it was only temporarily in charge until the delegates in Paris determined who was awarded the territory, the confidence of Deputy Prime Minister Jan Smuts was such that he took steps to ensure South Africa would be difficult to remove.

Military administration was implemented whereby German legislation, namely the Civil Code and the Criminal Code, was left in place except where it impacted on martial law. This remained the position until the mandate was approved, when systems were adapted to those of the Union of South Africa which had been awarded the mandate on behalf of Britain (du Pisani). The Union being in nominal control of the territory permitted Afrikaner trekboers to move in to boost the white population in an attempt to alleviate the "black fear" and add further support to South Africa's claim to the land; land it felt Britain had incorrectly given to Germany in the 1880s. In 1917, in an attempt to boost the case for South Africa being awarded the territory at the peace discussions, the Union published a Blue Book on German atrocities in South West Africa. Compiling this publication necessitated numerous interviews with the local population, an action which had a propagandist effect in winning "hearts and minds." According to Christo Botha, the occupation of South West Africa created a situation where the forward-looking and thinking Germans were controlled by Afrikaans Boers who were still caught up in a pastoral life. This was to cause some friction when the Germans who remained in the country were denied equal rights as set out in the mandate document. Of the approximately 12,000 Germans who had been resident in South West Africa at the start of the war, half were repatriated to Germany and their farms handed over to South Africans (Botha).

Before being repatriated from April 1919, many women, children and elderly men had been sent to South African internment camps during the war whilst Germans captured during the campaign were put into camps in remote locations such as Aus - locations the Germans had initially used to imprison South Africans. The delay in repatriating Germans was no doubt due to the lack of shipping and the priority to return dominion soldiers home to prevent unrest which was starting to develop. In camp, with little chance of survival if they escaped and nowhere to go other than to East Africa, the prisoners set about building more permanent accommodation, vegetable and flower gardens. For the Kaiser's birthday in January 1916 they built a monument to celebrate (Bruwer).

South Africa's reaction to the Germans was mixed. Whilst reservists had been allowed to return home along with indigenous labour, officers and noncommissioned officers were interned. After the war, some internees would be allowed to stay in the conquered territory if their standing could be vouchsafed. This led to friction within the community where individuals who coveted property 
filed false claims against the owner, in the hope that the latter would be repatriated and the land given to the accuser (Bruwer).

Whilst many, such as the Bondelswarts, in South West Africa seemed to welcome South African control and assisted the invading forces, others took the opportunity of the change in power structure to fight for their independence. In Angola and along the border into South West Africa, a power vacuum had been created by the German invasion of Portuguese Naulila. This led to both South African and Portuguese attempts to restore order in the area; a task which took years to achieve. The juxtaposition of suppressing a people whilst at the same time accusing the previous controllers of rule with the sword was evident in South West Africa. While presenting the case against German re-occupation of South West Africa, the Union was launching a campaign against the Ovambo Chief Madume who was opposing white rule (EISA).

Alongside having to manage new territory, the South African government also had to keep a watchful eye on the men who had rebelled. Many were released after paying a fine, but tensions remained. Wilbur Smith in The Burning Shore (1985) has a rogue Boer, who evades capture during the rebellion and South West Africa campaign, assist German submarines locate British ships. A shipwrecked survivor crossing the Namib desert remains ignorant of the war ending till three months later when the Boer happens to rescue her from an attacking lion. The distrust and dislike between English and Boer continues amongst sections of both communities.

A related African territory which had to cope with peace from 1914 was the Caprivi Strip or Zipfel in the northern part of South West Africa, which surrendered to forces from Northern Rhodesia on 22 September 1914. The German officers were sent to Livingstone in Northern Rhodesia for the duration of the war and then, along with others repatriated to Germany. During the four years of war, the area was administered by four South African appointed army captains, which did little to stabilise the area. In 1916, the High Commissioner of South Africa, Lord Buxton, visited the area to reassure the Barotse of their rights to remain in the Caprivi Strip. This formed part of Buxton's wider tour where he also reassured the Katanga in Belgian Congo that South Africa had no designs on their territory despite it being rich in mining minerals. Times were uncertain and rumour rife around fulfilling long-term land desires at the peace talks.

\section{East Africa}

The armistice in Europe was to have the biggest impact on the East Africa theatre where fighting continued to the end. The resulting occupation of German East Africa by Britain resulted in English becoming the dominant unifying language over Kiswahili which had been developing as such following its use during the 
1905 Maji Maji rebellion. However, by 1928 the idea of standardising Kiswahili across the region had taken hold again. This was a significant move for developing a written language and later fictional writing (Park 79). The extent and range of the campaign in terms of geography and manpower has led to the greatest number of fictional accounts being written on this theatre of war (Samson 2014). Of the eight covering the end of the war, the only East African author is MG Vissanji, although most have had experience of living in Africa. In addition, it is the one theatre for which there are various personal accounts, surprisingly few official, of the surrender, some of which were published in the media soon after.

November 1918 saw most of the fighting forces in East Africa in the southeast corner, in Nyasaland (Malawi) and Northern Rhodesia (Zambia) to be more precise. The German forces under Paul von Lettow-Vorbeck had moved out of Portuguese East Africa (Mozambique) back into the German colony (Tanzania), causing distress for the British civil administrator who had recently taken control. From there the German forces marched into Nyasaland and on 1 November after attacking Fife (Nakonde) crossed into Northern Rhodesia. Here, the forces led by AN Spangenburg, planned to launch an attack on the town of Kasama, roughly $240 \mathrm{~km}$ from the Tanzanian border and $320 \mathrm{~km}$ from Karonga in Malawi, the site of one of the early German attacks in August 1914.

Jarvis Murray, serving with 4 King's African Rifles, wrote about his last days of the war:

By the 9th [November] we were out of touch of everything with our wireless, and continued out of touch with everything behind us. On the 12th, we had another severe engagement, knowing nothing of the Armistice. In this night I was slightly wounded through my arm, and also side, but it did not lay me up.

On the morning of the 13th, we again skirmished with the enemy near Kasama (which is between Lakes Banguelo and Mivero) intending to heavily attack them again on the 14th. While moving along the road to Kasama, on the 13th about mid-day, we met two of von Lettow's Askaris, with a large white flag, and a cyclist of our own, who gave us the great news of the Armistice and Peace. It appears that, a couple of hours before, two of our cyclists had passed, on their way to deliver despatches to our Batt[alion] and to von Lettow. Thinking we were in Kasama, von Lettow received both despatches - so getting the news about two hours before we did. On receipt of the news there was tremendous excitement amongst our people. Porters, Askaris, officers and local natives all joined in the continuous cheering. The news came most unexpectedly. We at once halted, and so did the enemy, who were about five miles off. (3)

The news of the armistice was welcomed "with ringing cheers" as recorded in Comrades Ever! (348) and relief at not having to fight any longer. With it, however, came confusion as described in An Ice-Cream War (364) where a despatch rider arrived in German-occupied territory, the officer not knowing peace had been 
declared. The situation was not helped by Lettow-Vorbeck's challenging of the surrender, believing the allies were trying to fool him. It was only on 18 November that he finally accepted the Kaiser's abdication and agreed to lay down his arms. The same day, Jarvis Murray's brother Lennox, based in Kigoma at the railhead on Lake Tanganyika, was sending cattle south to Bismarckburg where the Germans were surrendering. This was to supplement the German rations. Lettow-Vorbeck had made it known that he would have no food supplies to feed his force of around 3,000 after 22 November.

The final official surrender took place on 25 November 1918 at 17.40 when the documents were signed by von Lettow-Vorbeck for Germany and General Edward Frederick Savery Edwards representing Great Britain. At the surrender ceremony in Abercorn (Mbala), there were 30 white officers, 125 other Europeans, 1,165 Askari, 1,516 enlisted carriers, 482 local and Portuguese carriers, 13 headmen and 819 women (29\% of the total local force) (TNA WO 158/905). In attendance were men of 4 King's African Rifles and the Northern Rhodesia Police, two contingents which had served for almost the whole duration of the war. Fictional heroes were also present at the surrender, namely Drew Spaight of Rhodesia (Duncan) and Simon Fonthill together with his batman Jenkins and trusty tracker Mzingeli, the latter three getting bored with the proceedings (Wilcox).

The Germans were to be escorted to Dar es Salaam for transport back to Germany whilst their askari, carriers and followers were paid and released to return home. Lennox expected Lettow-Vorbeck to pass through Kigoma on his way to Dar es Salaam on route to Germany and eventually on 12 December the two Murray brothers saw each other briefly as Jarvis moved to Tabora. He arrived with the same boat as Lettow-Vorbeck (Murray 3). Rosemary in Curse of Magira is in Dar es Salaam to wave farewell to Lettow-Vorbeck, while Kate, the woman Lettow-Vorbeck married in Ghosts of Africa lay buried where she had died shortly before news of the armistice was received by the German commander; the author Stevenson blaming revelry and drunkenness for the delay in the message getting through.

The end of the war saw men discharged at staggered intervals which caused some upset. The impact was variable as noted by the Murray family in Kenya. Jarvis Murray was discharged in January which allowed him to get married on 3 February, however, his brother Lenox was only discharged in March and therefore missed the joyful occasion. In addition, Jarvis discovered that as he had taken leave earlier in the year he was to be penalised in terms of pay and transport - a regulation he had not been made aware of being in one of the remote territories. The brothers returned to the family farm in "West Kenia" to experience "a strenuous time, getting this building habitable [...]" (Murray 1, 2, 7). In addition to looking after their own farm, the brothers were involved in supporting the soldier settler scheme where there were 2,000 local and 5,000 applicants in England for 800 farms. 
The land in the conflict areas was poor. In addition to the ravages of war, "there is terrible drought and famine [in Dodoma], and the country looks as bad as the Karoo could look after the worst of droughts. The distress amongst the natives here is terrible, and they are dying in their hundreds from starvation. This has been going on for the last year, and now it has come to a climax." Lennox (8-9) continued in harsh terms about how the local black population was being exploited by the sale of food and grain for animals.

In his fictional account, Book of Secrets, M. G. Vassanji (221) writes:

And then finally one day came the end of military authority. The tents and uniforms, the animals and vehicles, the thousands of soldiers had gone; the town was cleaned up. And the residents of Dar took stock of what happened.

There were those who had come from the interior wiped out, to unload their woes on family and community. And there were others, whose fortunes had risen in the same war, who had bought out the Germans, foreclosed on loans, received outlandish collaterals, smuggled, hoarded, supplied the arms. Property was scarce in Dar [...]. (221)

Brian Wade, who went to East Africa after the war to manage a mine supports the challenges faced in Peace, War and Afterwards:

Morogoro, 6 January 1919. This is a frightful country at present in which to buy anything. I am in need of knives, forks, serviettes, table cloths and a hundred more little items for a household. I am hoping to buy up such things from the local German householders who are to be repatriated about the middle of the month. (86)

Others were excited and "as soon as I can pinch a leave, I'm off to dear old London to have a good time. Grilled steaks and bottled beer, taxi cabs, jazz-teas, theatres and any other excitement" (Lynn 389).

\section{Egypt}

Turkey's entry into the war on the side of Germany in October 1914 created a dilemma for the British who had until then controlled Egypt through a consulgeneral ostensibly recognising the territory's nominal independence and allegiance to the Ottoman Empire. In order to ensure control over the country which, through the Suez Canal, formed a vital link between Britain and its Asian Empire, the British declared the area a protectorate. This led to unrest with the result that after the Gallipoli campaign, some of the returning troops were directed to deal with the rebelling Egyptians. South African forces on their way to the Western Front also found themselves diverted to Egypt to bring the Senusi to heal. In 1916 the British defeated Darfur as part of an offensive-defensive move which brought the territory into the Sudanese-Egyptian sphere. This however, led to a period 
of violence as arms and ammunition were more widely and easily available, and power struggles between local leaders took place requiring the British administrators to get involved, often meeting violence with violence and using local loyal tribes or micro-nations against rebels (Vaughan). The situation was ripe for local communities to exact revenge from neighbours and to raid across the border into French territory leading to further destabilisation in the region. A lack of local knowledge by administrators often led to manipulation and biased decisions being made in favour of those who were able to obtain the confidences of the government. Decisions and actions from this time would have long-lasting repercussions.

Egypt found itself in an anomalous position. It became a base and half-way stop for British forces moving to and from the outlying areas of empire and a base for waging war against the Germans and Turks in Europe and Asia respectively. Having asserted its superiority over the Senusi in 1916, the British turned to Palestine and Sinai where Turkish forces were engaged. By the time the Germans collapsed in Europe, the campaigns in Palestine and Sinai were ostensibly won by the allies.

Reactions in Egypt to the end of the war were similar to elsewhere. F. R. Cobb serving with 1/4 Northamptons in Egypt wrote on 12 November 1918 (Rushton Echo):

Just a few lines to let you know we are having a royal time out here, celebrating the Armistice. I had the honour of playing the glad tidings on the piano. We had a tableau on the stage, including all flags of our Allies. As each flag was presented cheers were given by a very large audience, and I played the National Anthem as each one was presented. The boys gave vent to their voices; in fact, they sang till they were hoarse. I played all popular patriotic tunes, which suited immensely, but I think the two most popular ones were "Take me back to Blighty," and "I want to see the dear old Home again." There are numerous boys here from our county, so you can imagine we had a decent night together.

The paper continues with some cuttings of articles from Egyptian newspapers:

There were great scenes of enthusiasm in the streets of Cairo on Monday evening when the news became known that the Armistice had been signed. Cheering crowds marched through the principal streets; in the cafes would-be orators got up and made speeches, and "God Save the King" and the "Marseillaise" were repeatedly sung. The principal cafes and bars were crowded with customers, who were toasting the Allied Cause. Many of the Boy Scout Associations paraded the streets with music at their head. Altogether Cairo has not known so hilarious an evening for years. On Monday evening also all places of amusement were crowded, particularly the Kursaal, where the excellent Bandmen company gave their play "Billetted."

Lanver Mak, in an as-yet-unpublished article, estimates that there were about 9,000 British citizens resident in Egypt at the start of the war, some of whom stayed 
the duration working in hospitals and as civil servants. With many volunteering to serve, schools were left without teachers and other sectors suffered vacancies which affected their output. The large numbers of men moving through the ports, Egypt was one of the few countries to experience an economic boom during the war with the result that when peace was declared and the troops left, there was a slump until the markets readjusted. By that time, the world depression started to impact.

For the local population, however, it was time to reassert themselves as the British military presence reduced. Nationalism and a desire for independence came to the fore with the Al-Wafd al-Misri, WAFD party, being formed two days after the armistice. The intention was to have Egypt represented at the peace talks. With these attempts thwarted, tensions rose which erupted in demonstrations and other outbursts. In 1922 following discussions between Britain and the Sultan, Egypt became independent. As to reactions of the local populations, other than the recording of uprisings and the struggle for independence, little if anything has been written.

\section{Versailles Peace Talks}

A little over two months after the armistice came into effect, on 18 January 1919, the delegates to the Versailles peace talks met for the first time. One of the first topics to be discussed by the attendees was the fate of the German colonies and on 30 January 1919 the Council of Ten agreed that the German colonies would be awarded as mandates not as colonies or other permanent acquisitions. The detail of allocation was still to be determined and would result in various discussions, some lasting into 1923. This position was confirmed in Article 119 of the Treaty of Versailles, whereby Germany formally renounced all colonial claims in favour of the Allied and Associated Powers. Germany signed the document on 28 June 1919. The outcome was that the previous German colonies became subordinate to the League of Nations, administered on its behalf by named countries through Mandates. Togoland and Cameroon were identified B mandates which meant the governing country was:

responsible for the administration of the territory under condition which will guarantee freedom of conscience and religion, subject only to the maintenance of public order and morals, the prohibition of abuses such as the slave trade, the drug traffic, the liquor traffic, and the prevention of the establishment of fortifications or military bases, and of the training of natives for other than police purposes and the defense of territory, and will secure equal opportunities for the trade and commerce of other members of the League.

South West Africa was classified a C type mandate which allowed for the territory to be administered as an integral part of the country holding the mandate. 
South Africa's mandate over South West Africa was administered on behalf of the British government which had suzerainty over the Union.

Arriving at these decisions had not been easy, with those desiring territorial aggrandisement having to give way to the spirit of the 14 Points which President Woodrow Wilson of the United States of America had proposed and which had been agreed by the Peace Council. On 9 May 1919, the day the Germans were handed the terms of the Peace, the decision over who would get which German colony was initially agreed. The allocation left the Italians and Belgians to complain. The Treaty of London signed in 1915 resolved the Italian claim to land in East Africa but the Belgian claim led to further discussion.

The discussions between Britain and Belgium took place outside the formal meetings of the peace talks in an attempt to keep the American delegation out of the issue. The Americans, led by Wilson were against the allocation of colonies and Belgium objecting to Britain's claim to the whole of German East Africa would give the American delegation the leverage required to support breaking the British Empire. Of all the territory in German East Africa, that most wanted by Britain in 1919 was the land claimed by the Belgians - the territories of Ruanda (Rwanda) and Urundi (Burundi) occupied by the Belgians during the war. This land happened to be the most fertile in Africa but it also contained the strip necessary for the British to complete the imperial Cape Town to Cairo railway line stretching the length of Africa.

The outcome of the deliberations between the Belgians and Britain was a complex territorial swop which suited the desires of the imperial powers but which did not take local considerations into account. Belgium did not really want more territory in Africa as it was difficult enough developing the Belgian Congo which it had taken over from the Belgian King in 1909, although to assist in the Congo's development, obtaining the southern bank of the Congo River which was controlled by Portugal would be beneficial. The idea was that if Portugal was amenable to Belgium getting this territory, Belgium would cede its rights over Ruanda and Urundi to Britain. In compensation for ceding the west coast territory to Belgium, Portugal would be given the Kionga Triangle on the east coast which it claimed Germany had stolen from the country in the 1880s. In addition to the Kionga Triangle, Portugal would be given a strip of German East Africa bordering on the Portuguese East African divide to compensate for an equivalent strip in the south of Portuguese East Africa being given to the Union of South Africa. This move would round the Union territory to the Zambezi River, a long-desired aim.

The whole realignment of territory rested on Portugal. However, political instability in the mainland meant that politicians were reluctant to be seen giving away Portuguese territory even if the territory was an unnecessary drain on the treasury. It was an issue of status. Despite its desire for the Kionga Triangle the overall territorial loss was too great for the Portuguese to consider and they declined the proposal. The result was the map of Africa remaining as had been agreed at 
the Berlin Conference of 1885 slightly amended by the Treaty of Versailles and Mandate agreements. Kionga was awarded to the Portuguese as part of the formal territorial allocation. Of the countries which had fought in East Africa, the only one relatively satisfied with the outcome was the Union of South Africa which was awarded South West Africa as a $\mathrm{C}$ type mandate. This was the closest the Union would get to complete occupation and integration of the territory.

In the west, the British and French governments eventually agreed their spheres of interest on 10 July 1919. France had agreed to stay out of East Africa providing concessions were received in the west. By means of the Milner-Simon Declaration the boundaries of Cameroon and Togoland were defined (Elango). Yet, the final mandate agreements were only signed on 13 February 1923.

As alluded to above, many in the African territories saw the opportunity of the Versailles peace talks to have their nationalist aims addressed. This was partly inspired by the claim that the war had been fought to protect the rights of small nations; those making the decision assuming that their subordinate territories were excluded. Representations were made by black and white alike from South Africa, political parties from Gold Coast, Nigeria, East Africa and others. India put forward a special plea to Britain to obtain German East Africa as a colony to enable Indian emigration without the restrictions imposed by the other dominions. The Viceroy vetoed the idea believing there was sufficient space in Aden to allow for Indian expansion. Of all the separate representations, only Egypt was to have its nationalist desires fulfilled when it obtained its independence in 1922.

\section{The Aftermath in Africa}

The war and the ensuing peace discussions have had a lasting impact on Africa, consequences which are still reverberating in 2018. With all communities which experience conflict, there is the issue of reintegrating those who opposed the majority position, whether they were incarcerated or not. Economic adjustments are required as industries disrupted by the conflict are either found to be superfluous as a result of war-time developments, others require restarting while yet others no longer need to operate on the scale the war demanded. The accompanying social adjustments may require management especially when groups refuse to return to the position they occupied in the pre-war years. Each of the territories in Africa was affected differently based on its specific circumstances and involvement in the war, however general themes are identifiable.

Internees and prisoners of war needed to be returned to their countries of origin or reintegrated into the society. Similarly, soldiers and labourers needed to be returned home. This put continued pressure on transport links and governments who were felt to be dragging their heels. Questions arose over who had priority in being sent home: men who were prepared to sacrifice their lives for 
their country and beliefs, internees who had been deprived the freedom of travel because of being associated with the enemy or prisoners who still posed a potential threat. Men like Paul von Lettow-Vorbeck were returned on the first available ships whilst in August 1919, 336 internees from the Rhodesias, South West Africa and the Union, were still in Pietermaritzburg in the Union, awaiting repatriation to Germany (Dedering). Some, mainly South African residents had been allowed to slowly reintegrate back into society.

Soldiers, carriers and labourers needed to be demobilised. Questions over pensions and employment had to be addressed, often with unsatisfactory results when made by people who had little contact with the countries over which they were making decisions. To maintain internal peace, the South African government thought it best that black labourers were not awarded medals claiming that as they were employed as labour through recruitment agencies they were not technically entitled to medals. Similarly, uniforms and blankets had to be returned. The fear was that by retaining these items, men would be able to identify each other and form groups which could rise up against the white minority rulers (Grundlingh). In East Africa there was concern that releasing large numbers of German soldiers, labourers and carriers without some sort of payment would result in disruptions to local communities as the men passed through. This had to be avoided at all costs if the new administrators were to maintain peace and restore some control in the area.

The nature of the war and the movement of men meant that at the end of the conflict, people found themselves on leave in countries not their own, particularly men serving in the Royal Navy and Royal Naval Volunteer Reserve. Where they were on leave in their own country at the end of the war rather than being shipped back to England before demobilisation, they were processed at a local naval base such as Simonstown. As a result, men returned in small numbers, the first large group of 88 RNVR men arriving in South Africa on 14 April 1919 (Hay). Groups such as this were inspected and paraded through Cape Town or other cities whilst the others received no welcome reception. This was particularly pertinent for the future remembrance of the First World War in Africa as demonstrated by Anne Samson (2005) in the case of South Africa's involvement in the East Africa campaign.

Power structures had been eroded with the removal of chiefs to support the military endeavour. Leaders not loyal to the governing administration were replaced by men purporting to support the war effort and aims of the colonial power, often to the detriment of the traditional hierarchies, community stability and economic development as discussed by David Killingray in his study of the repercussions of the war on the Gold Coast. Returning soldiers and labourers having fought alongside the white man, and on occasion having killed the white man with none of the previously promised dire consequences, were more confident in standing up for their rights and wants. No longer was the white man's threat and power enough to awe, aspects Melvin Page considers in his work on Malawi (then Nyasaland). 
Missionary organisations experienced a decline in the number of missionaries they had in Africa. The combination of mission pre-war education and the impact of the war on local communities led to a growth in nationalism and panAfricanism led by local black missionaries. The distrust engendered between German and allied (British and French) missionaries eroded confidence and contributed to the undermining of white superiority. This had been exacerbated by their support of the war effort through co-ordinating carriers and intelligence as well as fund-raising (Prempeh).

To address the high unemployment of returned soldiers in England, ex-soldiersettler schemes were introduced as early as 1919 . These were to prove a failure as the men were given no agricultural training or financial support. Attempts were made to encourage white settlers to move to specific parts of Africa, such as East, South and South West Africa, to help create a bulwark against the majority black populations (Fedorowich). However, as the world economic slump took hold, so steps were taken to make the economies viable. As with the initial scheme, this was at the expense of local subsistence farmers who experienced severe hardship, Ochieng (122) recording that from being in a dominant export position before the war, local African farmers were only contributing 20 per cent of exports in 1928.

The outcome was political movements which developed in response to improved colonial organisation brought about by mass mobilisation, more effective and systematic collection of taxes and greater restrictions on traditional practices (Ochieng). As the colonial governments were able to build on the systems set in place during the war, so the local political leaders saw the benefits of organising themselves, working across tribal barriers and finding common ground in response to the increasing control they found themselves under (Hodges). In countries such as South Africa, women saw the opportunity to campaign for the right to vote, have a political voice and continue in the formal economic system.

In countries such as Northern Rhodesia, the investment into maintaining wartime infrastructure was allowed to evaporate, the Administrator noting that the upkeep of roads and motorised vehicles was in excess of what the economy could support. Roads were therefore allowed to revert to bush and traditional methods of transport - carrier and boat - were reverted to (Yorke, Gewald).

Significantly, the horrors and length of the war had such an impact on men that recruitment for the permanent military forces stagnated and in some cases even fell to below what it had been pre-war. However, McKenzie (58) notes that sufficient men remained to guide units into war again in 1939.

As in Europe, the Spanish flu caught everyone unawares. In Africa, the virus spread rapidly along the supply and communication lines, hitting hard those whose immunity was lowest having had little exposure to such diseases. The returning soldiers brought disease home with them, not all contagious, but it led to an increase in the number of recorded deaths such as malaria and blackwater fever amongst those returning from East Africa. In Gold Coast, of the 59 European 
deaths recorded, 28 were from influenza and of 7,756 local cases treated, 204 died. Added to this is an estimated 30,000 victims who did not get to medical treatment. In Ashanti alone an estimated 9,000 died from the epidemic (Prempeh). In Aus prisoner of war camp, South West Africa, 65 prisoners (4.1\%) and 60 guards $(8.3 \%)$ perished (Bruwer). Part of the challenge in treating the outbreak was the lack of medical staff - themselves caught up in the military machine. Death from the virus damped the feelings of relief the end of the war brought. Peter Rainier (1940), in Nigeria, records he had no interest in continuing to live. He had buried his wife and new born son two days before the armistice.

Disease added to the labour shortage led to reduced planting and care for crops. The result was an increase in crop disease, smaller harvests, greater famine, theft and poor health. Industry was just as affected when mines and other factories had to close for the duration of the epidemic, sometimes for two weeks (Rainier). The cycle was exacerbated by drought or flood depending where on the African continent a person happened to be. Returning able and fit men were less tolerant of poor working environments with the result that mines found it difficult to recruit. Trained men with diversified skills were in demand. Many moved to towns and cities where work and better pay was more readily available. Women, too, who had been involved in war-time work looked to retain their employment despite the men returning. Their economic independence accompanied by increased confidence resulted in conflict as many struggled to keep their new-found freedom.

Where boundaries had been changed and new administrators appointed to look after previous German territory, responses were mixed. Some welcomed the change until the new administrator started to behave in the same way the Germans had. Others, such as Mzee Ali (MacDonnel) in East Africa were concerned with the poor control and the resultant lawlessness which developed. Where tribes or micro-nations had been split by the decisions of the 1880s, the reinforcement of the boundaries by the Versailles delegates saw little change in these areas, as tribesmen such as the Masai continued to live their nomadic lives oblivious of the borders crossing their traditional lands. The Luo, Tumbuku, Taureg and Tebu amongst others developed a joint nationalism - one to the state and the other to their micro-nation; on occasion the two conflicting against each other. Other groups placed together in one nation-state has seen one dominate the other as witnessed in Zimbabwe where the Shona suppressed the Matabele and in Rwanda between the Hutu and Tutsi.

\section{Conclusion}

The First World War in Africa ended as it began, different territories reacting according to their individual circumstances. Experiences ranged from little direct involvement and the supply of material (Equatorial Guinea and Botswana) to complete immersion in the conflict either through the supply of manpower to 
the European theatres (French West Africa), or as a result of immediate military engagements (East Africa and Cameroon). Togoland and South West Africa spent most of the war years occupied by foreign powers. Everyone seemed to have been affected at some point by the war, if not for the duration. Experiences in the various African theatres, whilst similar in many respects, were variable depending on the extent and duration of colonial occupation, the relationship between colonised and coloniser, the availability of resources and acceptance of western culture.

Elie Allegret expresses the reaction of Africa well:

Something like a consciousness of the solidarity of the human race vibrated through them, but at the same time they were astonished, scandalized, frightened. Something also was shattered - the prestige of the white man and their confidence in him. At the same time the consciousness of race, of nationality and of the rights of man was becoming everywhere more or less acute.

The minds of the people were perturbed, intoxicated, unbalanced by the return of thousands of troops, who for the most part came back with feelings other than those of respect for the European $\cdots$ by the pan-African propaganda introduced from America and the English Colonies by the Bolshevist tracts with which certain parts of the coast were inundated, without the necessary counterpoise of moral training or of the training of conscience. (qtd. in Prempeh xxvi)

These feelings, across all micro-nations on the African continent played out in the post-war years to varying degrees, most notably in the struggles for independence and recognition. From white South Africa and Egypt obtaining recognition in the 1920 s through to the 1950s when the first black presidents were elected and still one hundred years later where minority groups continue their fight for basic rights.

The war provided an opportunity to realise dreams epitomised by Britain's desire to complete the Cape Town to Cairo railway. For this Britain needed land which was granted to Belgium. In the spirit of colonialism, Belgium offered Britain access and control of the strip of land needed for the railway but due to the first cross-continental flights taking place in 1923, Britain never completed the railway and returned the land - perhaps symbolic of the impact of the Great War in Africa. The war provided the opportunity for the final scramble for African territory to take place whilst simultaneously heralding the start of the struggle for nationalism and eventual independence.

Commemoration of the centenary of this conflict, which had such a defining impact on the African continent, has mirrored that of one hundred years ago - the muted reception received by most on their return home resonate in the absence of remembrance, whilst the cultural differences seem to echo as loudly today as they did then, not least around the issue of grave markers and memorials. Perhaps history can learn from rank-and-file interactions and fiction - in virtually all the novels of the First World War in Africa, black, Indian and white, male and female recognise the value and different contributions of the other. 


\section{Notes}

1 This argument is broadly supported by Ikhide R Ikheloa's article "Jollof Rice Wars, Cultural Appropriation, and the Ugly Heart of the Other's Darkness" ' in Enkare Review, c2016 online http://enkare.org/cultural-appropriation-ikhideikheloa.

2 According to Madeline Manoukin, The Ewe-speaking People of Togoland and the Gold Coast: Western Africa 6, (Routledge, 2017) this same book was published the same year by the British Foreign Office.

\section{References}

Bee, David. 1964. Curse of Magira: A Novel of East Africa. New York: Harper \& Row.

Botha, Christo. 2007. "Internal Colonisation and an Oppressed Minority? The Dynamics of Relations between Germans and Afrikaners against the Background of Constructing a Colonial State in Namibia, 1884-1990." Journal of Namibian Studies 2: 7-50.

Boyd, William. 1982. An Ice-Cream War. London: Penguin.

Bruwer, Johann. 1985. Aus 1915-1919: Errichtung, Bestehen und Schließung des Kriegsgefang-enenlagers bei Aus. Windhoek: Rat für Nationale Denkmäler.

Bruwer, Johann. 2003. The Prisoner of War Camp Aus 1915-1919. Windhoek: Namibia Scientific Society.

Centre for Communication Programmes Nigeria (CCP Nigeria). 2014. Remembering Nigeria's Fallen. https://ccpnigeria.org/2018/01/remembering-nigeriasfallen-heroes/

Change.org. "National Museums of Kenya Preserve Kariokor War Cemetery." https://www.change.org/p/national-museums-of-kenya-preserve-kariokorwar-cemetery

Cobb, F. R. 27 December 1918. "The Signing of the Armistice - Celebrated in Cairo: Rushden Music and Peace.” http://rushdenheritage.co.uk/war/armisticecairo1918.html

Dedering, Tilman. 2015. "Prisoners of War and Internees (Union of South Africa)." 1914-1918 online. International Encyclopedia of the First World War. Ed. Ute Daniel, Peter Gatrell, Oliver Janz, Heather Jones, Jennifer Keene, Alan Kramer, and Bill Nasson. Berlin: Freie Universität Berlin. https://encyclopedia.1914-1918-online.net/article/prisoners of war and internees union of south africa Duncan, Brian. 2016. The Lion and the Leopard Book 3. Kirtlington: Raasay. du Pisani, André. 2010. "State and Society under South African Rule." State, Society and Democracy: A Reader in Namibian Politics. Ed. Christiaan Keulder. Windhoek: Macmillan Education Namibia. 49-76. 
Dze-Ngwa, Willibroad. 2015. "The First World War and its Aftermath in Cameroon: A Historical Evaluation of a Century." International Journal of Liberal Arts and Social Science 3. 2: 78-90.

Egyptian State Information Service. 2017. Armed forces mark 103rd anniversary of participation in WW1. http://www.sis.gov.eg/Story/120450 and Egypt Today. https://www.egypttoday.com/Article/1/32176/Egypt\%E2\%80\%99s-Armycelebrates-end-of-World-War-I

EISA. 2009. African Democracy Project: Namibia South Africa Mandate (19151945). https://www.eisa.org.za/wep/namoverview5.htm

Elango, Lovett Zephania. 1987. The Anglo-French Condominium in Cameroon, 1914-1916: History of a Misunderstanding. Limbe: Navi-Group Publications.

Farwell, Brian. 1987. The Great War in Africa 1914-1918. New York: Norton.

Fedorowich, Kent. 1991. "Foredoomed to Failure: The Resettlement of British ExServicemen in the Dominions 1914-1930." PhD diss., University of London. Gewald, Jan-Bart. 2015. Forged in the Great War: people, transport and labour, the establishment of colonial rule in Zambia, 1890-1920. Leiden: ASCL.

Grundlingh, Albert. 1987. Fighting Their Own War: South African Blacks and the First World War. Johannesburg: Ravan.

Guerrillas of Tsavo. 2018. https://www.guerrillasoftsavo.com (also https://atcnews. org/2018/05/09/kenya-set-for-major-commemoration-as-the-100th-anniversary-of-world-war-1-draws-near/)

Hastings, C. E. 20 Nov 2014. "All the talk in WW1 seems to be about France..." Africa in Words. https://africainwords.com/2014/11/20/africa-ww1/

Hay, Serald. 1920. History of the RNVR South Africa Division. Cape Town: Juta. His Majesty's Stationery Office. 1919. Nigeria, Colonial Report for 1917, No 1008, Cmd 1-31. London: HMG.

Hodges, Geoffrey. 1999. Kariokor: The Carrier Corps. Nairobi: University of Nairobi.

Killingray, David. 1978. "Repercussions of World War I in the Gold Coast." The Journal of African History 19. 1: 39-59. http://www.jstor.org/stable/180611 Khumalo, Fred. 2017. Dancing the Death Drill. Cape Town: Penguin Random House Lawrance, Benjamin Nicholas. 2007. Locality, Mobility, and "nation": Periurban Colonialism in Togo's Eweland, 1900-1960. New York: University Rochester Press.

Lon, Joseph. 2013. "The Powerlessness of Cameroon's reunification monuments." East West University Journal 4: 1. http://dspace.ewubd.edu/handle/123456789/1181

Lynn, Escott. 1921. Comrades Ever! Edinburgh: W\&R Chambers.

MacDonell, Bror Urme. 2006. Mzee Ali: The Biography of an African Slave-Raider turned Askari and Scout. Pinetown: 30 Degrees South.

Mak, Lanver. Due 2018. "Diversity in Adversity: The British in Egypt during the First World War." Rickmansworth: GWAA. 
McKenzie, Angus G. 1956. The Dukes: A History of The Duke of Edinburgh's Own Rifles, 1855-1956. Cape Town: Galvin \& Sales.

Murphy, Mahon. 2017. Colonial Captivity during the First World War: Internment and the Fall of the German Empire, 1914-1919. Cambridge: Cambridge University Press.

Murray, Jarvis. July 1919. "The Surrender of von Lettow.” Chronicle of the Family. https://www.moltenofamily.net/stories-and-history/chronicle-of-the-family/

Ngung, George Ndakwena. 2016. "Soldiers of their Own: Honor, Violence, Resistance and Conscription in Colonial Cameroon during the First World War" $\mathrm{PhD}$ diss., University of Michigan.

Ochieng, William R. 1985. A History of Kenya, Nairobi: Macmillan.

Page, Melvin E. 2000. The Chiwaya War: Malawians in the First World War. Colorado: Westview.

Park, Jeong Kyung Park. 2004. "The Oral-Written interface in the Swahili Fictional Prose." Thesis, University of Nairobi.

Prempeh, Samuel. 1977. "In the Gold Coast and Togoland, 1914-1926: A Study in Protestant Missions and the First World War." PhD diss., University of Aberdeen.

Quinn, Frederick. 1973. "An African reaction to World War 1: The Beti of Cameroon." Cahiers d'études africaines 13. 22: 722-731. http://www.persee.fr/ doc/cea_0008-0055_1973_num_13_52_2682

Rainier, Peter W. 1940. My Vanished Africa. New Haven: Yale University.

Samson, Anne. 2005. Britain South Africa and the East Africa Campaign, 19141918: The Union comes of Age. London: IB Tauris.

Samson, Anne. 2014. "Fictional Accounts of the East African Campaign." The Great War in Post-Memory Literature and Film. Ed. Martin Löschnigg and Marzena Sokołowska-Paryż. Berlin: Walter de Gruyter. 397-410.

Smith, Wilbur. 1985. The Burning Shore. London: Pan.

Strachan, Hew. 2004. The First World War in Africa. Oxford: Oxford University Press.

Stevenson, William. 1980. The Ghosts of Africa, New York: Harcourt, Brace \& Jovanovich.

Vassanji, MG. 1994. The Book of Secrets. London: Picador.

Vaughan, Chris. 2015. Darfur: Colonial Violence, Sultanic Legacies and Local Politics, 1915-1956. Suffolk: James Currey.

Wende, Hamilton. 2005. The King's Shilling: A Novel, Johannesburg: Jacana.

Wilcox, John. 2015. Dust Clouds of War, London: Allison \& Busby.

Williams, Eric. 2017. "Indivisibly Invisible: The Presence of Africans in World War 1 African Historiographies." ResearchGate, https://www.researchgate. net/publication/319356752

Yorke, Edmund. 2015. Britain, Northern Rhodesia and the First World War: Forgotten Colonial Crisis. London: Palgrave. 


\author{
Donna Coates \\ (iD) https://orcid.org/0000-0001-7538-2187 \\ University of Calgary
}

\title{
Happy is the Land that Needs No Heroes
}

\begin{abstract}
This essay interrogates two articles by the Canadian historian Jeff Keshen and the Australian historian Mark Sheftall, which assert that the representations of soldiers in the First World War (Anzacs in Australia, members of the Canadian Expeditionary Forces, the CEF), are comparable. I argue, however, that in reaching their conclusions, these historians have either overlooked or insufficiently considered a number of crucial factors, such as the influence the Australian historian/war correspondent C. E. W. Bean had on the reception of Anzacs, whom he venerated and turned into larger-than-life men who liked fighting and were good at it; the significance of the "convict stain" in Australia; and the omission of women writers" contributions to the "getting of nationhood" in each country. It further addresses why Canadians have not embraced Vimy (a military victory) as their defining moment in the same way as Australians celebrate the landing at Anzac Cove (a military disaster), from which they continue to derive their sense of national identity. In essence, this essay advances that differences between the two nations' representations of soldiers far outweigh any similarities.
\end{abstract}

\section{Warrior Nations?}

In "The Great War Soldier as Nation Builder in Canada and Australia," Canadian historian Jeff Keshen argues that influential historians and war correspondents such as the Canadian expatriate William Maxwell Aitken, director of the Canadian War Records Office in London, and the Australian historian and war correspondent Australian C. E. W. Bean, helped to create "pumped-up" or glorified views of their soldiers, whose courageous battles at Vimy Ridge and Gallipoli reputedly achieved nationhood for their countries. Keshen cites historians J. L. Granatstein's and Norman Hillmer's description of the attack on Vimy as "a stupendous triumph that forged a national spirit that "made Canada into a nation'" (qtd. in Keshen 3), and then reports that according to the "standard story," the Australians, through "stupendous feats of arms, particularly at Gallipoli [...] transformed the new federation into a true nation" (4). Throughout his essay, which draws upon both historical and literary works (although almost exclusively by men), Keshen continues to render analogous the representations of soldiers, ultimately finding 
few, if any differences between Anzacs (Australian and New Zealand Army Corps) and members of the Canadian Expeditionary Forces (CEF) or their concomitant contribution to the shaping of issues of national identity. ${ }^{1}$ In his conclusion, Keshen reiterates that

[i]n Canada and Australia the modern memory of the Great War is one not only of muddy trenches and massive death but also of gallant men scaling the heights at Vimy Ridge or the cliffs at Gallipoli and thus producing the emotional/sentimental foundations of nationhood. The fact that both countries entered the Great War as colonies intent upon demonstrating their worthiness within the Empire predetermined that monumental significance would be placed upon their battlefield encounters. (20)

But my research (which also utilizes both history and literature, but mostly by women) reveals that any sentiments about "monumental significance" in "battlefield encounters" apply solely to the over-the-top veneration of the Anzacs' landing at Anzac Cove on April 25, 1915, and of the legend which persists to this day, even though it was a military disaster. By contrast, the Canadian soldiers' storming of Vimy Ridge over the Easter weekend of April 9-12, 1917, although considered a military victory, has never had the same potency as the Australian single unifying myth, but is rather, as Canadian historian Tim Cook puts it, "a layered skewer of stories, myths, wishful thinking, and conflicting narratives" [arguably including his own] (qtd. in Everett-Green).

Keshen is not the only critic to suggest that there is little difference between the representations of Anzacs and members of the CEF during the First World War and throughout the interwar period, however. In his abstract to "Mythologising the Dominion Fighting Man: Australian and Canadian Narratives of the First World War Soldier, 1914-39," American historian Mark Sheftall observes that "Canada [...] saw the emergence of a 'Myth of the Soldier' that paralleled the Anzac legend in many ways" (81; emphasis mine). Although Sheftall's essay purports to stress similarities between these two groups, he consistently undermines his own arguments by stressing differences between the two nations' mythologizing of their fighting men. He writes, for example, that "the Anzac legend remains one of the most potent popular myths in Australia" (81); that it is "one of the most exhaustively explored aspects of Australia's First World War experience" (81); and that "the power of a myth [is] crucial to the emergence of a national identity perceived as distinctly Australian" (81). Even though none of these observations has a Canadian counterpart, Sheftall presses on with another comment that also has no Canadian equivalent: "what is perhaps unique about Australia's pre-eminent First World War mythology [is] its resilience and longevity within that society as a central component of the dominant construction of Australian identity" (82). But having stressed the uniqueness of the Anzac legend, he then claims that "a narrative such as the Anzac legend is fundamentally not unique 
to Australia, but conforms to analogous mythologies that emerged at the same time in other British Empire settler societies [such as Canada] for a variety of similar reasons" (81-82). Throughout his essay, while continuing to emphasize "remarkable congruencies" (93) between Canadian and Australian narratives but without specifically identifying them, he concludes that "the stereotypical image of the First World War fighting man that emerged in each Dominion, though it varied in some specific details, was more or less identical" (98).

Why both of these historians insist on similarities when differences clearly carry the day is puzzling. In attempting to come to terms with why each writer insists upon commonalities, I begin with my suspicion (that is, no evidence) that neither historian has personally witnessed the manifest differences between Canadians' and Australians' commemorations of the war now and in the past. To underscore the disparity, I draw upon an anecdote concerning Eric Bogle, the Scottish immigrant who claims his iconic Australian anti-war song, "And the Band Played Waltzing Matilda," was inspired by a comparison with Britain's commemorative war practices. According to Michael J. K. Walsh, the song was "conceived in 1971, only two years after [Bogle's] arrival in Australia at the Anzac Day parade in Canberra" (239). Of that event, the songwriter has said,

I'd not seen anything quite like it before because in Britain it's one minute's silence once a year - a quick perfunctory prayer and that's it. There are individual small parades to lay wreaths but not a national day. So I saw this parade in Canberra - it wasn't a big one by national standards and it was right in the middle of the Vietnam War. (240)

Once the parade was over, Bogle reputedly "sped home and, armed with a bottle of whisky, wrote frantically for seven hours until the task was complete" (241). Sometime later, asked if he thought it was "ironic that a newcomer to the country should be the one to capture the spirit of Gallipoli and the futility of war," he replied that "being a migrant and not being involved in the Australian culture, I could see a lot of things Aussies couldn't see" (242). Bogle's story resonates with me because his description of the British commemoration, which closely resembles the Canadian, sounds familiar. (Significantly, Bogle's impressions in the 1970s and mine in the 1980s were formed when the Anzac legend was, according to many historians, on the wane.) Hence as someone from a country often referred to as "the peaceable kingdom," on my first trip to Australia, I was truly staggered by the Australians' adulation of the Anzac, which I first glimpsed at the numerous (albeit sanitized) exhibitions in the daunting War Memorial in Canberra. I was once again flabbergasted when I joined the tens-of-thousands attending the 4:15 a.m. Dawn Ceremony in Sydney ${ }^{2}$ and then further astonished by the hours-long parade that followed. I admit to being mildly perplexed by the solemnity of the previous events, then undercut by boozy celebrations on the streets. While I was not, like Bogle, motivated to produce an anti-war song, I was, 
like him, so astonished by the amount of attention paid to war, and specifically to the almighty Anzac, that I felt compelled to investigate why Canadians' and Australians' responses to war - and specifically the Great War - should have been and continue to be so dissimilar. But because it became obvious that only those who were mired in the "blood and muck" of the battlefield had acquired a compelling legitimate perspective, I felt the need to examine women's roles, particularly in terms of what they contributed to the formation of national identity, even though their interpretations had been elided from the canons of war literature in each country. Hence I conducted my study through the lens of Canadian and Australian women's war fictions which emerged either during or shortly after the war: not surprisingly, I found only differences.

\section{At the Outbreak of War, Some Similarities Existed}

At the outbreak of war, both nations' initial responses to war admittedly ran parallel, but as post-colonial cultures located vast distances from the fields of battle with populations eager to support Mother England during her time of need, they were, nevertheless, only following orders because, as members of the British Empire, when Britain declared war against Germany on August 4, 1914, they were automatically bound to follow suit. While it was up to individual governments to determine how much support each would send the Mother Country, there was never any doubt that both countries (Australia's population fewer than five million, Canada's fewer than eight) would rush to her assistance. At the outbreak, parliamentary members approved an overseas contingent of 25,000 men, with Canada bearing the full cost (Morton and Granatstein 6). Similarly, the Australian government immediately declared, also without consultation, that it would send a contingent of 20,000 soldiers to any destination required by the war office (Macintyre 142). Enthusiasm and unanimity for the imperial cause were evoked, and the song "Australia Will Be There" rang throughout the land (Turner 317). Recruitment in both countries was clearly unnecessary, as supply quickly exceeded demand, in part because a large number of men in both countries were either of British origin, British born, or recent arrivals. Their leaders' willingness to go to war also correspond, with financial hardship playing a key role. Robert Everett-Green notes that "the collapse of a land-speculation boom, a terrible wheat crop, and a surge in unemployment" ("Vimy") resulted in what Morton and Granatstein have labelled the nation's worst depression since the 1890s (1). In Australia, economic conditions were equally deplorable, with severe drought and the rate of employment dramatically on the rise (Macintyre 146). Opportunities to enlist in a war that was to be over in a matter of months must surely have seemed fortuitous to the unemployed, who made up a considerable part of the first contingents (Morton and Granatstein 10; Macintyre 146). Early 
pro-war rhetoric, too, was comparable, with both countries decreeing that the issue was one of civilization against barbarism.

Each country also faced bitter and divisive crises over conscription. Australian troops who enlisted did so voluntarily, but by 1916, pressured by the British government for reinforcements, Prime Minister William (Billy) Hughes held a referendum which asked the Australian people to require men undergoing compulsory military training but required to serve only within the Commonwealth and Commonwealth territories (introduced in 1911) to send them overseas. The opponents, primarily associated with labour movements and unions, also included Archbishop Daniel Mannix, an influential leader for many Irish Catholics and recognized as anti-British. The "No" vote held sway at that time and again in 1917; this second campaign, even more acrimonious than the first, was also contested by Anzacs in war zones. The issue of conscription was not raised again during the war ("Australia's Conscription"). In Canada, the 1917 conscription debate was equally fierce and contentious, with French-Canadians opposing conscription on the grounds that they had no loyalty to either Britain or France, and clearly they did not: "of the 400,000 Canadians who volunteered for service in WWI, fewer than one in 20 were French" ("Crisis"). ${ }^{3}$ French-Canadians also felt they had been betrayed from the outset, since Prime Minister Robert Borden had promised in 1914 that there would be no "obligatory military service known as conscription" ("Crisis"). Accordingly, when Borden introduced conscription in August 1917, French-Canadians believed they were being unfairly targeted. Farmers, too, were equally bitter when Borden broke his promise after the election to exempt their labouring sons. In 1917, the conscription bill provoked a general outcry and incidents of street violence, with one man killed. But on Easter weekend in 1918, "an effort to arrest suspected draft dodgers [...] resulted in several days of rioting and street battles in Quebec City [...]. The violence left four civilians dead and dozens injured, and shocked supporters on both sides" ("Conscription 1917"). The fallout of the conscription crisis continued for decades, with the Conservative Party failing to get votes; moreover, "memories fueled the flames of growing French nationalist passions and created a permanent wedge in Canada's linguistic divide" ("Crisis"), with French-Canadians certain they would always be a minority within Canada ("Legacy"), and hence their subsequent (failed) attempts at separation during the 1980s and 1990s.

\section{Historical and Literary Differences Abound}

A few minor differences existed: Australian military leaders' insisted that Australian troops be used together whenever possible (Turner 330), and stipulated that Australians would not fight well in cold climates - hence the decision to send the first contingents to Egypt (Turner 319). Although Sheftall claims that "aspirations 
for 'national' ascendance coexisted with strong sentimental and material bonds that ensured continued loyalty to, affection for, and membership in the Empire" (83) and Keshen concurs (4), historian Ramsay Cook posits that Canada did not respond to the Empire's call to arms as a colonial power in the manner it had done during the early days of the South African War ("Nationalism" 10-11) because, in essence, they had nothing to prove. Like Cook, historians Paul Stevens and John Saywell maintain that "the nation's reaction was one of a people conscious of their maturity $[\ldots]$ and anxious to demonstrate that Canada deserved to be recognized as a nation in her own right" (xiii-xiv). Canada entered the war, then, not as an inferior or adolescent dependent, but as an ally fighting shoulder to shoulder with the British, not so much for the British, an attitude also reflected in women's novels of the time, which accepted that Canadians went to war as part of the allied forces, opposing a common enemy together. In L. M. Montgomery's 1920 novel Rilla of Ingleside, for example, the adolescent Rilla acknowledges that the struggle for victory is shared between "the British navy and our Canadian boys" (91). By contrast, as Geoffrey Serle asserts, Australians responded as if colonials; they looked to the Mother Country with the undertone of a child staking its claim for parental recognition of maturity (150). To Australians, writes C. E. W. Bean in The Official History,

Great Britain was a fabled country, of which they had learned at their mother's knee, the home of wonderful things - of the many stories of childhood, of snow and lawns and rivers and castles and wonders seen only on Christmas cards. In the common language the motherland was still often spoken of as "home." (16)

Although Bean declared that Australians regarded Britain as "an old friend in danger" to whose side they automatically hastened in time of need, he also noted that Australians went to war because they aspired to convince their ancestors that, out of their inauspicious beginnings as a penal colony, they had forged a superior culture. Contemporary Australian historian Carolyn Holbrook agrees; she points out that "though Australians belonged to the great British race, they felt deeply the shame of their convict heritage. It was gallant performance, rather than the peaceful means by which nationhood had been achieved in 1901, that would redeem the original sin of convictism" (51-52). And as Robert Hughes also observes, while "the convict vestige" had been slowly dying out, "it was part of English attitudes before 1960 and especially before World War Two": when mentioned, it would "send upper-middle-class Australians into paroxysms of social embarrassment [...]. [C]onvict ancestry was a stain to be hidden" (158). But despite the seriousness of the issue of the "convict stain," neither Keshen nor Sheftall mention it. Once again, literary women reflected the thinking of the time. In her novel On the Knees of the Gods, set in England, Brookes vehemently underscores Bean's dictum that Australians had indeed become an incomparable race. Her 
upper-class Ernestine takes umbrage when an English aristocrat suggests that Anzacs evacuated Gallipoli because they lacked stamina, and swiftly replies that few, if any of them "are of convict blood. That page of Australia's history has long been turned over and is hidden beneath many others that are inscribed with records of golden deeds" (71). Ernestine insists that "you'll find the finest men that God ever made among their ranks" (71). It appears that Australians wanted the British to "sit up and take notice" that those from Down Under were not only as British as the British, but in fact better than them. Annie Rixon, another writer taking Bean's cue, records in her novel Yesterday and Today that while Australian soldiers wished to see England, which they still considered "home," they wanted more than anything to be seen:

All the soldiers thought of, all they talked about, was what they would do when they reached the old country. They had already heard and read so much about it and were so eager to get there and to see it: so brimful of history and tradition. How they would hold up their heads and push out their chests as they marched through the streets of London, that wonderful city which seemed to regulate the pulse of the whole British empire. They would prove to the people of Old England that Australia could rear sons just as fine as she. (53)

The amount of and type of attention paid to war writing in each country further highlights the differences in colonial outlook. Australian writers insisted upon lauding their soldiers' participation in combat, whereas Canadian writers displayed no equivalent desire to extol their soldiers who joined the fray. In fact, Canadian historian Syd Wise writes that a gross imbalance exists. In his comparison of military and historical writing in each country, he argues that Canadian literature on war has, historically, been sadly lacking. As evidence, he furnishes a brief account of the attempt in Canada to publish an official history of the Canadian Expeditionary Force (CEF) in the First World War and laments that it covered the events only until September 1915. Although Keshen acknowledges that the proposed eight-volume official history of Canada in the Great War resulted in the production of only one, which did not appear until 1938 (12-13), he does not explore the impact of such neglect on Canadians, as does Wise in the following passage:

What this means is that the Canadian people between the wars obtained no official account and precious few other accounts of the Canadians at the Somme, at Vimy Ridge, at Passchendaele, or of the junction of the Australian Corps and the Canadian Corps on 8 August 1918 as a spearhead which broke through the German lines and created what Ludendorff called the "black day of the German army," or any record of the succession of Canadian victories in the hundred days which ended the war. Given the size and nature of the national effort (not to speak of the nearly 70,000 men who lost their lives during it), the failure to produce the CEF history was grievous and irreparable. (4) 
Moreover, no separate history of the Royal Canadian Navy in the First World War or a history of the Royal Canadian Air Force appeared (5). In spite of the fact that over 20,000 Canadians took part in the first air war, and some, such as Billy Bishop, William Barker, Raymond Collishaw, and Wop May were among the most outstanding of all Allied fighter pilots ${ }^{4}$ Canadians left the history of these famous flying men to the British, and consequently, in the six-volume official British History, War in the Air, there are only six references to Canada (5).

Australians, by contrast, more than accounted for their own contribution to the war effort. F. M. Cutlack's one-volume history of the Australian Flying Corps has no Canadian equivalent (5), nor is there anything comparable to Bean's comprehensive twelve-volume The Official History, which took him twenty-three years to complete (4). Although Keshen asserts that it was Bean who "initiated a campaign to construct a national, unrivalled testimonial in Canberra," which opened in 1941 and which also appears to be, as he intended, "the finest war memorial' in the world" (17), he fails to mention that prior to 2005, if Canadians wished to learn how their stories of war had shaped the nation, they could only visit what Tim Cook describes as "the dilapidated Canadian War Museum. Established in 1942, it had suffered for decades from an inadequate budget, and was in desperate need of an upgrade. Its exhibitions were stale and out-dated, and it was less a museum and more a mausoleum" (353). Norman Hillmer adds that the Canadian War Museum was "one of the most neglected of federal institutions. Its usual fate was pedestrian quarters, meagre financial resources, and a miniscule staff" ("Canadian" 19). He notes that a "magnificent new Canadian War Museum building rose up in the national capital" in 2005 (19). While the new museum is a vast improvement over the old, it is nowhere near the "finest" in the world; nor can it boast, as does the imposing war memorial in Canberra, that it is the most-visited tourist attraction in the country.

\section{The Anzac Legend: Australians' Unifying Myth}

Whereas Canadians' national division into two linguistic and cultural communities has historically sharply divided, not unified the country, as French Canada still feels that it was conscripted into a British war, the story of war in Australia is surprisingly unified. While it is often argued that landing at Gallipoli was the significant event, literary critic Shirley Walker has argued that writers such as bush poet-cum-war correspondent Banjo Paterson had begun glorifying Australian soldiers' participation in war before the turn of the century. His widely circulated dispatches from the Boer War reinforced pro-war sentiments at home such as the soldiers' superb abilities as bushmen, and often cited individual acts of great courage, many of which concerned men well known in civilian life. Although Paterson suppressed incidents of larrikin behaviour and downplayed violence, his writing "fostered 
the establishment myth - of war as a gallant and necessary enterprise in aid of the Empire of Australia as a nation moving towards maturity and demonstrating this by the courage of its superior (if somewhat rakish) young men" (209). As early as the Boer War, then, bush legend had begun to blur into warrior myth.

While Paterson was a powerful myth-shaper, there were other, even more dominant male writers whose work reinforced a unified view of the Australian male character who liked to fight and was good at it. Not the least of these shape-shifters was Bean who, in many respects, was himself a reincarnation of the bush writers. In the early 1900s, the Sydney Morning Herald had sent him on a journalistic assignment to New South Wales, and his findings, published in On the Wool Track (1910) and The Dreadnought of the Darling (1911), honoured the Australian countryside and became the source, or the foundation, of his writing. According to Robin Gerster, Bean idealized its "almost mystical capacity to invigorate both body and spirit," and termed it "the real Australia" (74). A citydweller himself, Bean was clearly in awe of the bush, where he observed men had to live the lives of strong men (emphasis mine). (Whether or not women had to live the lives of strong women in the bush Bean did not address.) Ultimately, like the revered bush writers of the 1890s such as Henry Lawson, Joseph Furphy, Steele Rudd, and Paterson, Bean worshipped the Australian male character; his reports on the noble bushman and his values echoed these writers' depictions formerly set down in prose and poetry, but with one major difference: according to historian Peter Stanley, for Charles Bean, "nationhood stood at the core of what Gallipoli meant" (217).

It is important to stress that Bean was not the only war correspondent eager to turn Diggers into idols, however, particularly after the momentous landing at Anzac Cove. In fact, it is possible to speculate that Bean's reporting might have cut little ice with the folks at home had it not been corroborated by other correspondents, particularly those from Britain. The seasoned London journalist Ellis Ashmead-Bartlett gave high praise to the Anzacs when he stated that "there has been no finer feat in this war than this sudden landing in the dark" (19), words that were flashed to the home front via the Argus on May 8, 1915. Serle notes that "[ $\mathrm{t}]$ ributes by military historians and the fulsome, cloying eulogies of John Masefield and Compton Mackenzie were widely quoted and well known during the war" (151). Several of these are worth re-producing because they illustrate the excessive, even fanatical verbiage those on the home front were exposed to. Masefield labelled the Anzacs "the finest body of young men ever brought together in modern times. For physical beauty and nobility of bearing they surpassed any men I have ever seen; they walked and looked like kings in old poems" (19). Mackenzie's praise, if possible even more laudatory, also likens Anzacs to Homeric heroes:

There was not one of those glorious young men I saw that day who might not himself have been Hector or Achilles. Their almost complete nudity, their tallness and majestic 
simplicity of line, their rose-brown flesh burnt by the sun and purged of all grossness by the ordeal through which they were passing, all these united to create something as near to absolute beauty as I shall ever hope to see in this world. (80-81)

In the eyes and ears of the world, not only to women on the home front, the Anzac was a Herculean hero, an antipodean Achilles, a man more than worthy of the 'lofty pedestal' writers such as Mabel Brookes, Ray Phillips, Annie Rixon, Mary Grant Bruce, Ethel Turner, Gladys Hain, Chrystal Stirling, Linda Webb Burge, who collectively produced more than fifteen novels in praise of the Anzac, placed their soldiers on. ${ }^{5}$

While it might seem logical to assume that Australian women writers would have used their pens to record their frustration at being handed passive roles as mothers and copers on the home front or to lament that there was no largescale munitions industry and no shortage of labour to force them into men's jobs (McKernan 55-56), they did not: rather than using their words as tools to overcome their oppression, ${ }^{6}$ to write their issues and concerns over prohibition or conscription or pacifism into the discourse, they became the women with the pens behind the men with the guns. To be fair, it is easy to see how the glowing reports of both home-grown, but especially foreign correspondents, would have lured women writers into Anzac adulation. Like their male counterparts (who wrote surprisingly little fiction about Gallipoli), they portrayed their Anzacs as a splendid new race of larger-than-life characters who readily transferred their abilities from the bush onto the field of battle, and effortlessly achieved victory. In these wartime novels, each fighting Australian is tall, bronzed, and handsome, and always a superstar, never a colonial inferior. Because Australian women writers had so clearly imbued the notion that a nation which could produce such a great race of men (emphasis mine) could not have much wrong with it, their novels stress that the status quo had to be preserved and innovation opposed. In resisting societal restructuring which would have doubtlessly occurred had they taken advantage of men's absences from the home front, writers failed to recognize that they were shoring up national ideologies which oppressed them as women, and which kept them ensconced as second-class citizens in their own country.

\section{Time for Change: Canadian Women's Great War Fictions}

In Canada, however, women writers, although far fewer in number, had no desire to safeguard the status quo, as the winds of change blow through their texts. In L. M. Montgomery's Rilla, women are fully aware that "the beautiful yesterday [...] never come[s] back" (227); nor do they want it back. Female characters in novels by Montgomery, Nellie McClung, Grace Blackburn, Francis Marion Beynon, Gertrude Arnold, and Evah McKowan look to the future and visualize a better world where women are fully participating members of Canadian society. 
In part because there were no influential writers like Bean or Paterson aggrandizing members of the CEF, no reporters fashioning them into superhuman legendary figures, in Canadian novels, women are everywhere present. Because they had not been subjected to such biased, propagandistic, and downright misleading reporting, Canadians were more accurately informed about their troops' participation, and about the war, than were Australian women writers. Peter Buitenhuis relays that when Max Aitken went to France in 1915 to document the activities of the CEF, the reports he sent back to be printed in Canadian and British newspapers regularly gave the names of units and of officers and men engaged in battle in defiance of censorship rules (98). Buitenhuis acknowledges that although Aitken glossed over failures in allied strategies, he also admitted mistakes and acknowledged casualties (98-99), whereas Australians on the home front received principally glowing praise of the Anzac.

Canadian soldiers' war efforts did not go completely unrecognized, however, and while some of the admiration of the men in the CEF even issued from high places, it failed to capture the Canadian imagination the way similar comments did in Australia. Both Buitenhuis and Keshen note that Aitken accorded soldiers excellent publicity in France. In the first volume of Canada in Flanders (1915), Aitken wrote that Canada's "gallant sons" proved their manhood: "the wave that fell on us around Ypres [...] has baptised the Dominion into nationhood - the mere written word 'Canada' now glows with a new meaning before all the civilised world" (qtd. in Buitenhuis 99). But the flames were quickly extinguished, for as Morton and Granatstein stress, "the Great War did not forge a nationality for Canada, as it did for Australia" (1). Rudyard Kipling did, however, single out Canadians for special praise. On his 1914-1915 tour of the camps of the New Army, the British poet claimed that Canadian soldiers "were all supple, free and intelligent; and they moved with a lift and a drive that made one sing for joy" (qtd. in Buitenhuis 25). Witnessing a group of soldiers digging a trench, he commented first on their physical appearance, but then made a more telling comment about their demeanour: "They were young $[\ldots]$ they were beautifully fit, and they were all truly thankful that they lived in these high days [...]. It was their rigid humility that impressed one as most significant" (qtd. in Buitenhuis 25). If Canadian women writers absorbed anything from Kipling's commendations, it was "rigid humility." Accordingly, they do not place their soldiers on lofty pedestals, bolster their egos, or act as magnifying mirrors to enhance their fighting prowess; nor do they write as if they are publicity agents for the CEF. Women writers never depict their soldiers as "beautifully fit" or exalt them as magnificent fighters. In their fictions, soldiers do not declare they like to fight, nor do they boast of being "good" at combat. Most go to war half-heartedly, some even reluctantly, seemingly aware they were facing a daunting task, not a "picnic" or a "lark," as Australian women writers often suggested, and these Canadian soldiers return, as soon as possible, to the farms and factories of peace. 
Typical of Canadian humility, fighting prowess is never recorded as a characteristic of the Canadian soldier, nor are there any overseas correspondents highlighting their fighting ferocity: as I have pointed out elsewhere, ${ }^{7}$ the most praiseworthy act a soldier performs in a Canadian novel comes through ink, not blood. Montgomery's Walter Blythe writes a poem which is published in the London Spectator; within a month, it carries (flashes?) Walter's name to every corner of the globe:

Everywhere it was copied - in metropolitan dailies and little village weeklies, in profound reviews and "agony columns," in Red Cross appeals and Government recruiting propaganda. Mothers and sisters wept over it, young lads thrilled to it, the whole great heart of humanity caught it up as an epitome of all the pain and hope and pity and purpose of the mighty conflict, crystallized in three brief immortal verses. A Canadian lad in the Flanders trenches had written the one great poem of the war. "The Piper" by Private Walter Blythe was a classic from its first printing. (167)

This Canadian soldier distinguishes himself and his country with the point of a pen, not the tip of a bayonet.

Moreover, in Canadian texts, heroes are poets and thinkers; brain, not brawn, is acclaimed. Before he goes to war, Walter openly confesses that he is a coward, but Montgomery makes his fear of fighting more meritorious than any display of aggression and masculinity. No Canadian writers celebrate, much less "big-note" (Australian for excessive praise) one man's ability to kill another. Moreover, Canadian women writers staunchly resist the notion of either individual or collective heroism. Montgomery's Rilla refuses to countenance that her brother Walter, who died performing a courageous deed, deserves to be singled out for attention: "He was just one of many fine and splendid boys who have given everything for their country" (194), she declares. Although Walter writes home to tell his family that he has earned a medal, he does not consider his act of heroism worth recounting. Only later does the family learn from a comrade-in-arms that Walter dashed from the safety of the trenches to drag in a wounded comrade, thereby risking his own life (166), and ultimately proving that Bean's much-touted mateship was not unique to Australians. Another of Montgomery's soldiers receives the D.C.M. and writes his family about the award, but does not tell them what he earns it for. Meaningfully, Montgomery does not inform her readers why either.

Unlike their Australian counterparts, Canadian writers refused to privilege the voices of soldiers; they insisted that it was women to whom attention must be paid, that their stories from the home front were of equal importance to men's on the battlefield, and that their perspectives were vital to a complete, not partial, view of war. Hence in Canadian novels, soldiers' tales are merely background to the main events, which routinely take place on the domestic front; women replace the soldier as mouthpiece for war. They are the active presence in the novels. Theirs are "counter" stories to war in part because they had no role models to 
obey. There were no influential writers eulogizing members of the Canadian Expeditionary Forces, no ideologies insisting that Canadian soldiers were superior fighters, and no mutual admiration society equivalent to the Digger Fan Club. As a result, Canadian women, unfettered by tradition, were free to invent their own images of war. They used their imaginations to depict what it would have been like to be a soldier in the trenches, how it felt to face combat, how men regarded their participation in war. Because women writers were fabricating, not mimicking men's first-hand reports of war, readers might assume that their portrayals would be unrealistic, lacking in credibility, but the reverse holds true: it is Australian women writers who create fatuous depictions of international warfare.

The accounts of the Canadian soldiers' bravery at Vimy Ridge, which neither the French nor the British had succeeded in taking from the Germans is, as Montgomery's narrator observes, "written in crimson and gold on the Canadian annals of the Great War" (208). But even though the conquest earns a welldeserved place in history, because of the loss of life required to earn the victory, the battle represents tragedy rather than triumph to the villagers. Here, Montgomery reminds readers that mastery in battle is only partial, good news only to the survivors. In sending its young men off to war, even though they fight in defense of a noble cause, as a nation, Canada is making a tremendous sacrifice. Unlike Australian women writers, who uniformly perceive of the gains as 'our country's good,' Canadian women writers evoke a different metaphor which signifies loss, not profit. In order to underscore the tragedy war brings, women writers fashion their soldiers into nearly perfect specimens of humanity. As McClung's narrator bemoans in The Next of Kin, "the blood of our brightest and best [is] being poured in out [our country's] defense" (41). At the same time, there is no hint in any text that Canadian soldiers are superior on any playing field; there is no competition waged for cultural supremacy, no desire on the part of Canadian women writers, as there is in Australian women's texts (again following Bean's lead) to demean the English as stunted, inferior, or cowardly, or as products of a blighted industrial landscape.

Canadian writers do stress, however, the intellectual superiority of their young men. Montgomery underscores her young men's future promise as professionals and community leaders by opening her novel in early August (at the start of war), but also just as the summer is drawing to a close, and the boisterous, fun-loving denizens of Glen St. Mary are preparing to return to college. Several of the crowd are completing medical degrees, others studying English literature; some are heading off to their first posts as teachers. The tiny village seems permeated by scholars; even the news that the war has officially begun is announced by a McGill medical student (32). Attractive, intelligent, and well educated, all seem assured of brilliant careers and destinies as pillars of their communities. The two central young men in Grace Blackburn's The Man Child are of similar makeup to Montgomery's male figures: both inhabit a tiny Ontario village and are enrolled in 
medical school when they enlist. Jack, "the man child," wooed by Johns Hopkins University in Baltimore, is one of the country's best doctors in training. When he joins the army, he displays a special aptitude for military service and quickly becomes an officer (218). Like other Canadian soldiers, he is tall, physically fit, "matinee-idol" good looking, and popular with women (252). But in contrast to Australia, where writers often stress the sunny climate and abundance of good food, in Canada, writers like Blackburn make only passing reference to the notion that the backwoods of Canada produces hearty, healthy men (101). The Canadian landscape does not then produce a race of Sampsons; more commonly, particularly in the fiction of Montgomery and Blackburn, it is a place of beauty and serenity where prior to going to war, young men read or write poetry.

Both Blackburn's soldier figures are, like Montgomery's, dutiful, devoted sons, and mentally gifted. Well informed about current events, steeped in history, these young men are also versed in Greek tragedy, Shakespearean drama, and classic novels; their lively debates range over topics like free will or the struggles of the English suffragettes, their arguments bolstered by literary passages they recite at will. In creating these superlative young men, writers are emphasizing the loss a nation suffers when it sends its sons to war, not arguing that Canadians are culturally or racially superior to the British. Because Canada was never a penal colony, there is no need for writers to fear, or disprove, that cultural and moral degeneracy has set in; moreover, there are few larrikins, or rowdy men, in Canadian women's texts. While it may seem that the fictional Canadian soldier appears to be stamped from an incomparable die, Canadian writers freely own that soldiers have flaws in their personalities: Beynon's recruit, a well-known Winnipeg newspaperman, possesses a passion for the Demon Drink (Aleta Dey 165), and one of Montgomery's recruits is absent-minded in the extreme: a bluecollar worker, he enlists without informing his family he has gone to war. Like their Australian counterparts, some Canadian soldiers may be redeemed by their participation in war, but within Canadian women's texts, a pattern cannot be forced: the representation of the soldier is far from uniform.

Additionally, Canadian women novelists are cognizant that men suffer more than glancing bruises to their wrists in combat (which Bean insisted was the case, as he carefully sanitized the soldiers' submissions in The Anzac Book [1916]), and that Australian women writers then carefully copied. But in The Next of Kin, McClung's narrator speaks poignantly of the "scattering remnants" that came home from war: "Empty sleeves, rolled trouser legs, eyes that stared, and heads that rolled pitifully appeared on the streets. On the sunshiny afternoons many of these broken men sat on the verandas of the Convalescent Home" (150). Beynon's Aleta, too, refers to the mutilation which occurs during conflict: "It broke our hearts to read of men with their legs and arms blown off; with their faces shattered to pieces; men who would go on living under the most horrible physical limitations" (164). Montgomery's fighters suffer keenly: one loses the sight of an 
eye; another has a leg amputated, and the narrator bemoans that "none of them came back just as they went away, not even those who had been so fortunate as to escape any injury" (272-273). Three of the village's young boys sleep permanently under the Flanders poppies (185). The housekeeper's trenchant remark that "four hundred thousand of our boys gone overseas - fifty thousand of them killed" (247), is a powerful reminder of the horror and pity of war.

In spite of the plethora of Australian texts, however, Anzacs remain invincible: only two die. In Canadian texts, the deaths of Montgomery's Walter Blythe and Blackburn's Jack Winchester move readers to tears because, even though these fighting men are not the focus of the novels, they seem like genuine, flesh-andblood characters who are aware, as Elaine Scarry insists, that "the central activity of war is injuring, and the central goal is to out injure the opponent" (12). She also emphasizes that "the object of war is to kill people" (61), a "fact" routinely obscured in Australian war writing, but not in Canadian novels. Montgomery's Walter tells Rilla that when he "sees [himself] thrusting a bayonet through another man - some woman's husband or sweetheart or son - perhaps the father of little children," he knows "[he] never can," because he could never "face the reality" (81). Blackburn's reluctant recruit, too, argues that if people used their brains to think about what war truly is, they would realize it is "nationalized murder" (126). Even though Montgomery, like Australia's Mary Grant Bruce and Ethel Turner, writes for a juvenile audience, she refuses to shroud the realities of war in euphemism. In the Canadian novel, then, the coward, or the man who does not want to fight because he comprehends what war means, is the real hero. Notwithstanding their awareness of the horror and suffering they will face in the trenches, they set aside their own fear and loathing, and willingly sacrifice their lives for others. Moreover, Montgomery's soldiers are free to admit their fear, their loneliness, their sense that they are involved in a tragedy too horrible to comprehend, as their letters home frequently convey. They can scarcely fathom that they inhabit a planet - familiar yet strange - in which men deliberately destroy one another.

In Australian women's texts, however, writers do not have sympathy for men who refuse to fight, in part because they had no real understanding of what war was like, and no expressed desire to find out. Thanks to war correspondents like Bean and Paterson and home-front versifiers like Dennis who painted war as a quixotic romp, women writers were convinced that men were off to a thrilling adventure, a "contest," a "stunt." Hence they had no compassion for shirkers or deserters, those not game to play the "game." They seemingly did not comprehend that a man may not want to fight because he finds killing reprehensible. In Broken Idols, Brookes' heroine treats a deserter with disdain (76), and in Rixon's novels and Mary Marlowe's 1918 The Women Who Wait, those who avoid the colours are deceitful good-time Charlies who prefer to exercise their physical prowess on the footie field, not the battlefield. Grant Bruce is especially hard on shirkers, condemning them as "unmanly." But in making these cruel judgments 
that only war can make the man, that only a man who revels in action can be a man, women writers were once again not thinking for themselves, but following Bean's interpretation of the character of Australian men as their guide. At the end of the first volume of The Official History, Bean declared that what sustained the stalwart Diggers on the shores of Gallipoli was the idea of Australian manhood. Here, he evokes the heroic war myth which decrees that manhood is best tested on the battlefield; outmoded as the notion was, Gerster suggests that "the muchvaunted virtuosity of the First AIF was that of the Latin virtus - a manifestation of pure physical force and energy, of male strength, wilfulness and comradely resolve" (20). In Bean's view, "real" Australian men liked to fight, and hence in their fictions, women applaud the belligerence of the Anzac.

It would be foolish to suggest that Canadian women's wartime fiction was widely praised; like Australian women's writing, most of which sank immediately into oblivion, it, too, was largely ignored by the male canonizers, although works by L. M. Montgomery and Nellie McClung were best sellers and enormously popular. Nevertheless, Canadian women, at liberty to criticize their society, were obviously writing from a more powerful place within their literary tradition. Unlike women writers, who had to write (shoot?) back to a clearly defined patriarchal tradition which excluded them, Canadian women profited from writing out of a culture which lacked a particularly readily identifiable identity. Literary critic Coral Ann Howells asserts that the lack of a fixed Canadian identity has aided women writers: "the Canadian problem of identity may not be the problem of having no identity but rather of having multiple identities, so that any single national selfimage is reductive and always open to revision" (26). Since multiplicity refuses to privilege one set of cultural values over another, women writers have been at liberty to rewrite male myths from the woman's point of view; they have not had to be "myth-fits" or restricted to telling "official" stories of soldier-heroes, for there were no "myths" in this peaceable kingdom about war and warriors. ${ }^{8}$

\section{Origins of the Anzac Legend}

According to historian Marilyn Lake in her 2010 What's Wrong with ANZAC? The Militarisation of Australian History (co-edited with Henry Reynolds), because the landing at Gallipoli was a defeat followed by an evacuation, Bean's "nationalist myth-making had to focus on a different sort of triumph" (6-7). What he chose, she asserts, was "the demonstration of 'manly character' now known in more gender neutral terms as 'the spirit of Anzac" (7). Lake records K. S. Inglis' summary of the roots of the legend as follows:

It was at Gallipoli on 25 April 1915 [...] that the Australian and New Zealand Army Corps (ANZACS) made good: a nation was born on that day of death. War 
provided the supreme test of manhood. As the official war historian, C. E. W. Bean wrote, the Great War served as a test of Australian national character and the men of the Australian Imperial Force (AIF) had passed that test triumphantly. Despite the Gallipoli campaign ending months later in military defeat, for Australia its triumph lay in the mettle of the men themselves. To be the sort of man who would give way when his mates were trusting to his firmness [...] to live the rest of his life haunted by the knowledge that he had set his hand to a soldier's task and had lacked the grit to carry it through - that was the prospect which these men could not face. Life was very dear, but life was not worth living unless they could be true to their idea of Australian manhood. In proving their manhood - brave, firm, loyal and steadfast - these men (so it was said) had proven our nationhood. (2)

Lake further observes that while there have been periods when the attention paid to the Anzacs' storming of Gallipoli has waxed and waned (14-15), in recent decades, "the relentless militarisation of [their] national history" has resulted in an "Anzac spirit [...] now said to animate all of [the country's] greatest achievements, even as the Anzac landing recedes into the distant past" ("Preface" vii). The "militarisation" of Australia, Lake argues, has taken place over the last decade: "the federal government has invested millions of dollars in the project of shaping historical memory, through the expansion of war memorials, the proliferation of plaques, annual pilgrimages to battlefields, the development of war-focussed curriculum materials for schools, massive subsidies for book and film production and most importantly, the endless ritual of public commemoration" $(2006,15)$. She attributes the "endless supply" of money to Prime Minister Howard's "personal interest in promoting military history" $(2006,15) .{ }^{9}$ Lake further asserts that the "entry of the Department of Veterans' Affairs into the business of pedagogy and curriculum design" has worked to "sideline different stories of nation-building" such as "visions of social justice and democratic equality" (10) in favour of military prowess.

Lake also attests that "schoolchildren are now conceptualised as the inheritors of the Anzac spirit and its custodians. They have been bombarded [some even as early as pre-school] in recent years and throughout the year with every aspect of the history of our engagement in overseas wars" (137). But they are not taught, as Patricia Grimshaw, Marilyn Lake, Ann McGrath, and Marian Quartly stress in Creating a Nation, 1788-2007, that

In determining the meaning of men's deeds $[\ldots]$ the metaphor of men's procreation involved a disappearing act. In this powerful national myth-making, the blood women shed in actually giving birth - their deaths, their courage and endurance, their babies -were rendered invisible. In determining the meaning of men's deeds - their Landing at Gallipoli - women's procreative capacities were at once appropriated and erased. Men's deeds were rendered simultaneously sacred and seminal. Through women gave birth to the population, only men it seemed could give birth to the imperishable political entity of the nation. (214) 
Nor are they taught that the history of Australians at war did not begin on April 25, 1915. According to Matthew Bailey and Sean Brawley, "considerable gaps in public awareness about [other] foundational events" such as the frontier wars which, "despite a wealth of [...] scholarship documenting the violence and dispossession that characterised European colonisation," are not on school curriculums. Recent scholarship suggests that the prominence of the Anzac legend "has served to mask other, important histories of the continent, including frontier conflict" (19). Much of the recent scholarship on this glaring omission has been done by Henry Reynolds, whose Forgotten War queries whether "Australia was a site of genocide" (148).

\section{No Birthing of the Nation in Canada}

Although Tim Cook is correct in thinking that Historica Canada's polls designed to find out how much Canadians know about their past are "not the most effective way to gauge knowledge" (347), they are, nevertheless, one of the few tools at a country's disposal. While I have never read the results of any polls which inform Australians how many are aware that they attained nationhood on April 25, 1915 (perhaps because such polls are unnecessary), numerous surveys have been undertaken recently in Canada, all with revealing results. In the "Historical Notes" to his 2007 play Vimy, Vern Thiessen insists that even though it has been "argued aggressively by noted historians and average citizens alike that Vimy Ridge was the symbolic birth of Canada as a nation" (221), Canadians are not familiar with the story. Here, Thiessen draws upon a poll conducted by the Globe and Mail in 2002, which found that "only 36 per cent of Canadians could name Vimy Ridge as the most significant Canadian victory of the war" (221). Moreover, journalist Anthony Jenkins observes that "there is a pervasive and persistent ignorance about the battle of Vimy Ridge" ("Why"). For example, when asked to identify "Canada's most famous single victory in the First World War which consisted of the capture of a key ridge on the Western Front," even the obvious clue failed to elicit an accurate answer, as only "one-third of Canadians, and only 25 per cent of Canadians between the ages of 18 and 34" were able to identify it as Vimy Ridge. (The results are precisely the opposite in Australia, as Anna Clark's recent interviews revealed that "younger respondents [aged thirteen to thirty] more often exhibited an abiding, uncritical fealty to Australia's Anzac legacy than their older counterparts. That youthful interest in and engagement with Anzac history is confirmed by studies of school-children, who, with the exception of Anzac topics, generally loathe learning Australian history" [25]). Nicole Thompson points out that in a 2014 survey, only forty-seven percent of Canadians could correctly identify that Vimy Ridge "was fought in the First World War"; eighteen percent were unaware that Vimy Ridge was one of Canada's "most notorious battles": nine 
percent thought Vimy Ridge was "a Canadian mountain range"; and three percent believed Vimy Ridge "was a famous Canadian racehorse" ("Looking Back").

In my experience, however, even some of those figures seem high. Over many decades, I have taught hundreds of university students in both junior and senior English courses, many of which focus on Canadian war literature, and I can verify that over that vast period of time, only a handful of my students have been able to identify the military or historical significance of Vimy Ridge or even what war it was fought in: to date, none have suggested that it was the first time all four visions of the Canadian Corps fought together as a national army; none have declared that soldiers captured an impregnable fortified German position that French and British troops had, over two years, failed to win, despite their many losses; none have mentioned the extensive preparation and training which employed new tactics and techniques (many admittedly devised by the British) that contributed to the soldiers' victory; none have mentioned that success came at a price, with over 10,000 casualties, including 3600 deaths; and none have reiterated the familiar claim that military historians such as David Bercuson like to assert, which is "that the sacrifices, and triumphs, of the Canadian Corps gave prime minister Borden the leverage to win constitutional equality for Canada within the empire" (qtd. in Keshen 1). Clearly, the events at Vimy Ridge are not on many school curriculums at any level, a fact that historians have been bemoaning for years: as Granatstein informed Douglas How, "the history of the Canadian experience "has all but disappeared from the school curriculum' and the university situation is just as bleak" (92). Moreover, I cannot resist noting that even politicians who ought to have made it their business to know their history did not: according to Arthur Weinreb, when former Defence Minister John McCallum attempted "to answer criticism for his apparent lack of knowledge about the raid on Dieppe that took place in August 19, 1942" by writing a letter to the National Post on September 1,2002 , he succeeded only in making matters worse when he confused "Vichy, the seat of the French government that collaborated with the Nazis during World War II, with Vimy, the World War I battle of Vimy Ridge"! ("Vimy").

Another factor that contributes to Canadians' lack of awareness about Vimy is that few have visited the memorial site in France. Even though Brian Bethune claims that there is no shortage of people who make the trip, "only three percent of the 750,000 annual visitors to the site of Canada's greatest military triumph are Canadian. The rest are British and French, mostly schoolchildren, who come to see the battleground" ("Sublime" 31). Once again, the situation is drastically different in Australia. Whereas it remains unusual to meet a Canadian student who has been to Vimy, it is equally uncommon to meet young Australians who have not yet journeyed to Gallipoli or are planning to soon. As Bruce Scates asserts in Return to Gallipoli: Walking the Battlefields of the Great War (2006), a work which documents the long history of Australian pilgrimages, contrary to all expectations, the memory of the war has not faded with the "last of the diggers" 
(214) as some expected; rather, "the Anzac mythology and the pull of the Peninsula has grown even stronger" (214). He concludes that "Anzac Day has become fashionable, especially at Gallipoli and especially amongst the young" (214). (Lake takes a dimmer view of these pilgrimages; she suggests that Anzac Day is no longer a "day of solemn remembrance," but has instead "become a festive event celebrated by backpackers wrapped in flags, playing rock music, drinking beer and proclaiming their national identity on the distant shores of Turkey" [3]). Significantly, there is no Canadian equivalent to Scates' book on pilgrimages, nor is there any Vimy Day public holiday. There is, however, a Vimy Ridge Day, which is "an annual observance on April 9 to remember Canadians who victoriously fought in the battle of Vimy Ridge [...]. The day is also known as the National Day of Remembrance of the Battle of Vimy Ridge" ("Vimy Ridge Day"). But the short list of "what Canadian people do" on this day - museums may hold "special activities" such as inviting people to tell stories about the battle or dressing up in costumes to explain soldiers' equipment; people may lay wreaths at memorials, while students attend classroom lessons on the history of Vimy - seem trifling when compared to Anzac Day rituals and ceremonies ("Vimy Ridge Day").

\section{Once Upon a Time, Vimy Mattered}

Journalist Michael Valpy asserts that there was a time when the taking of "Vimy [Ridge] was recognized as a Canadian victory in places that mattered then, as now, to Canadians - the American and British press. Canadian Prime Minister Robert Borden, in London at the time, wrote in his diary: "All newspapers ringing with praise of Canadians." The New York Times declared that the battle "would be in Canada's history [...] a day of glory to furnish inspiration to her sons for generations [...]." The New York Tribune declared in an editorial: "Well done, Canada. No praise of the Canadian achievement can be excessive" ("Vimy"). On the home front, however, it did run to excess, as historian Jonathan Vance observed that "across English-speaking Canada," there was a "phenomenal, even bizarre, outpouring of poetry. Most of it was doggerel and much of it pointedly weaved together the sacrifice of the Canadian young men with the Easter crucifixion and resurrection of Jesus" ("Making"). But after those initial bursts of public pride, publicity, and poetry, the Battle at Vimy was nearly forgotten: "the British military historian Basil Liddell Hart awarded it only a paragraph in his authoritative account of the war" ("Vimy"). Valpy further notes that "Canadians, and only Canadians, call it the Battle of Vimy Ridge [...]. In everyone else's historical lexicons, it was a limited tactical victory in the First World War's horrendous Battle of Arras, which the British and their allies lost" ("Vimy"). While it is often argued that the Battle of Vimy Ridge altered the course of the war, Valpy insisted that "it had a negligible effect on the war's outcome. The Canadians had 
equal casualties and more strategic successes in other battles, such as Amiens and Passchendaele" ("Vimy").

Soon after the conflict, however, one meaningful event contributed to keeping the Vimy story alive in the hearts and minds of Canadians: that was the awarding of the Toronto sculptor Walter Allward's design for a national memorial. As Cook observes, the Vimy site, which France had ceded to Canada in 1922 "freely and for all time" (Carrigg) in gratitude for its sacrifices and for the victory achieved by Canadian troops in capturing Vimy Ridge, was ultimately chosen because it was "awe-inspiring in conception, size, and design, and regarded by many as one of the finest war memorials of the Great War" (Brown and Cook 39). The project, begun in 1922, was not completed until 1936. At that time, the stunning memorial, unveiled to an audience of tens of thousands, including several thousand Canadian veterans who made the pilgrimage overseas, served to remind Canadians and their allies of the young country's sacrifice and success. At the unveiling of the memorial, Canada's Minister of Justice, Ernest Lapointe, reinforced the peaceful messages carried by Allward's magnificent sculptures when he remarked that "Humanity desires [...] justice and truth, and is eager for a Peace founded in conscience and international solidarity, on the will of nations to co-operate for the greatest good of the greatest number of men and peoples" (Brown and Cook 48). Similarly, as Jacqueline Hucker insists, "in contrast to earlier war memorials, the monument made no reference to victory. Instead it spoke to national and universal goals for good in the world. It also alluded to the ancient cyclical myth of death and resurrection" (283). ${ }^{10}$

With the onset of the Second World War, however, the general safety of the memorial became a cause for concern for the Canadian government, as rumours flew that the Germans had destroyed the memorial. Such speculation eventually led the Germany Ministry of Public Enlightenment and Propaganda to publish denials that Adolf Hitler, who "reportedly admired the memorial for its peaceful nature, was photographed by the press while personally touring it and the preserved trenches in June 1940. The Welsh Guards who captured Vimy Ridge in 1944 confirmed that it had not been desecrated" (Canadian National 9). Ironically, after such an intense desire and commitment to preserve Vimy Ridge, little attention was paid thereafter either to the battle or the memorial, both having been overshadowed by more contemporary events. Only when the Vimy anniversary coincided with the birth of Canada celebrations in 1967 were turnouts more numerous (although neither Prime Minister Lester Pearson nor French President Charles de Gaulle attended), but tended to dwindle again until the $125^{\text {th }}$ anniversary of Canadian Confederation and the $75^{\text {th }}$ anniversary of the battle coincided in 1992, when both PM Brian Mulroney and French President Francois Mitterand attended (Carrigg). The largest crowd at the site since 1936 appeared on the $90^{\text {th }}$ anniversary of the battle in 2007, with Queen Elizabeth II, who "rededicated the site," and Prime Minister Stephen Harper in attendance (Carrigg). Prior to the $90^{\text {th }}$ anniversary, 
however, evidence that government officials had been allowing the monument to crumble came to light when in 2000, the Globe and Mail's European correspondent, Alan Freeman, wrote that it was falling apart ("Disgrace"). Only after he documented its decay on the newspaper's front page - which included that names carved on the monument were starting to disappear - did the Canadian government announce a restoration plan for all of Canada's Great War memorials in in France and Belgium, with the bulk of the money earmarked for the Vimy memorial. Or as Valpy puts it, "our dismissal of our own mythology," as well as "our contempt for the dead," shamed the government into action ("Setting").

\section{Who Cares About Vimy in the Twenty-First Century?}

Recently, numerous constituencies have echoed a similar kind of "who cares?" attitude towards Vimy. Journalist Graeme Hamilton reports that in Outremont, a leafy suburb of Montreal, Parc de Vimy, so named for more than eighty years, was suddenly re-named Jacques Parizeau Park. Ironically, while Vimy Parc had been named as a tribute to soldiers who fought to defend Canada, it was now being renamed for a man who fought to break it apart. The then-Montreal mayor of Montreal, Denis Coderre, who voted in favour of the name change, promised to find another park by 2017 and name it Parc de Vimy, but no announcement has been forthcoming (A3) ${ }^{11}$ Arguably, many of the 25,000 Canadians who eagerly accepted the federal government's invitation to apply online to attend the centennial anniversary celebrations at Vimy Ridge on April 9, 1917 (their presence thereby marking the largest assemblage ever at the site), had good reason to wonder if their government cared about them or the events at Vimy at all. Many who attended (me among them) were surprised to learn that the government's report of the event, apparently issued at the end of June, described Vimy as a "'rousing success': all events ran on time, on budget and virtually without incident" (A6), when we were aware that they didn't, and it wasn't. It took several months before journalist Tom Spears, who obtained documents through an access-to-information request, was to tell the "real" story, which detailed the event as "a total disaster. Appalling" (A6). His article, which appeared in December 2017, charged that "provisions for safety, basic human needs and crowd control were dangerously inadequate" (A6).

\section{Attempts to Militarize Canada}

But what prompted so many Canadians to want to celebrate an event they had largely ignored for decades? Cook attributes the "renewed interest" in Vimy to the Conservative government of Stephen Harper, which had been emphasizing a "more aggressive version" of Canadian history, one that "highlighted Canada 
as a proud member of allied forces," and to that end "resurrected the War of 1812 as an event that shaped the destiny of the future Canada" (Vimy 373). He further stresses that "Vimy was one of the icons used by the Conservatives to support the notion that Canada was a country not just of peacekeepers but also of warriors" (373). On what Cook terms the "politicized" ground of Vimy, Harper used his speech during the 2007 Vimy celebration to justify the war in Afghanistan by linking it to the sacrifices and values of the fallen heroes of the Great War and making it emblematic of our heroic military tradition (362). Another of Harper's initiatives was to rewrite the citizenship guide, which now focused on Vimy:

The Canadian Corps captured Vimy Ridge in April 1917, with 10,000 wounded or killed, securing the Canadians' reputation for valour as the "shock troops" of the British Empire. One Canadian officer said: "It was Canada from Atlantic to the Pacific on parade $[\ldots]$. In those few moments I witnessed the birth of the nation." (373)

It is useful to compare this description to what appeared in the former guide. According to Noah Richler, the previous government, in its description of Canada as a "gentler, more accepting, multicultural idea of the country" (41), more accurately reflected the mood of the country, which at the time

aspired to be a peaceful society society in which respect for cultural differences, equality, liberty and freedom of expression is a fundamental value. Canada was created through discussion, negotiation and compromise. These characteristics are as important today as in the past. (41)

According to Cook, these lines of attack (which Richler notes included thirty-five references to the word "military" but "peacekeeping" only once) worked, as Vimy "stormed back" into public consciousness in 2007, and apparently with Cook's approval. In the conclusion to his recent book on Vimy, Cook cites Harper's insistence that "Every nation needs a creation story to tell, and the First World War and Vimy are central to that story" (364), but following immediately on those words, Cook himself asserts that

All nations have them. All nations need them. They are forged over time, codified in cultural products and political discourse, and passed down from generation to generation. Vimy is one of Canada's most long-lasting of these narratives, even though it is one that has ebbed and flowed over several generations, taking on new meanings and shedding old ones. (364)

On page 379, Cook repeats that "All nations have founding myths and enduring narratives. Vimy is one of our strongest," and then reiterates on page 381 that "all nations seek out, create, elevate, and actively shape narratives on which to hang national stories of aspirations." 
Among the numerous detractors do not share Cook's (or Harper's) views about Vimy as a persistent narrative is historian Jamie Swift, who summarizes the problems in a short essay. He insists that those who want to make Vimy the "formative moment" for Canada (37) are slamming the door on "the indispensable historical insights that social and cultural historians have developed since the 1960s on the gendered, racialized and class-based dynamics of power. It replaces history with patriotic fantasy" ("Yearning" 39). The Vimy mythology, he argues, "constitutes a regressive return to the Great Man Theory of History, with all of its gender-specific simplicities" and also "minimizes and exiles Quebec" ("Yearning" 39). Furthermore, he insists that any notion that the Battle of Vimy Ridge was somehow Canada's coming of age smacks of what he calls "vapid Vimyism," a virulent form of martial patriotism that obscures Great War reality. He claims that Vimyism emerged as the Official Story after those who could directly and personally remember the magnitude of the war's tragedy were no longer alive to dispute it ("Yearning" 37). Swift suggests, too, that in 1936, when the Vimy Monument was unveiled, it did not celebrate militarism, but "conveyed the widespread yearning for peace - which is how most people interpreted Allward's majestic towers and mournful sculptures, unveiled with a minimum of militarism and an abundance of peace symbolism" (38). Swift and his colleague Ian MacKay have recently produced several books which debunk any notion that it is possible to find positive meaning in the Vimy Ridge conflict which, in their view, was a devastating and appalling battle, not an event that defined the spirit of an emerging, modern Canada. (It is worth pointing out that while McKay and Swift do not mince words in their declaration that Canada has never been a "solely Warrior Nation" [Warrior Nation xii], or in their more recent claims that the "standard version of Vimy is a highly dubious, mythologized narrative," that it is "akin to a fairy tale for overaged boys who want their history to be as heart-thumping and simplistic as a video game" [Vimy Trap 7], they have not, to my knowledge, ever been accused of being "un-Canadian" or courted any charge of treason.)

While the Harper government openly disparaged that the peacekeeping mythology never completely died out, it failed to acknowledge that the sentiments it reflects have deep roots. Many Canadians continue to believe that former Prime Minister Lester Pearson seemed to personify Canada, that his diplomacy at the United Nations won him, and us, the Nobel Prize for peacekeeping. Moreover, history books tells us that Canada invented peacekeeping, and although we are no longer the world's pre-eminent peacekeepers, we are the only country that has sent soldiers to every important mission since the UN defined its peacekeeping role. For many Canadians, the image of Canada as international do-gooders is part of the national mythology. Even though Canadians have lost faith in their military and in their peace-keeping forces, many still regard themselves as "peacemongers." While Richler admits that the country has experienced some peacekeeping disasters (47), he also claims that "peacekeeping is a core myth" 
which has been an integral part of our character for more than fifty years (58), and recent polls confirm it. Not long after the Trudeau government was elected in 2015, journalist Chris Selley declared that Canadians "love the peacekeeping thing" (A8). An Angus Reid poll conducted during the election campaign "found that 74 per cent preferred that Canadian troops be 'focused on peacekeeping' instead of 'combat preparedness' - among Liberal-intended voters, it was 82 per cent" (A8). While Selley rightly points out that Canada has not been a "major player in peacekeeping" for many years, Richler claims there are other means of maintaining the peace: we call upon treaties and negotiation as the Canadian way, we achieve political ends without the use of force, we have never relied upon guns to solve conflicts, and we tend to resolve issues through discussion and compromise, all of which contribute to the greater good, to a fair and just society. Richler further acknowledges that Canadians do fight for democratic causes and claims that we have never invaded another country for territorial gain (28-33).

\section{Canadians Resist the Single Unifying Myth}

Although Australians can pinpoint their "getting of nationhood" to the Anzacs' dawn landing at Anzac Cove at precisely 4:26 on the morning of April 25, 1915, Canadian literary critic Robert Kroetsch has asserted that "in Canada we cannot for the world decide when we became a nation or what to call the day or days or, for that matter, years that might have been the originary moments" (360). Our indecision is an advantage, argues Kroetsch, because "if we can't be united, we can't be disunited. Our genealogy is postmodern" (360). In making his claim that Canada is a "postmodern country," Kroetsch draws upon French critic JeanFrancois Lyotard's definition of postmodern as "incredulity toward metanarratives [...]. The narrative function of metanarratives is losing its function, its great hero, its great dangers, its great voyages, its great goal" (356). Again following Lyotard, Kroetsch emphasizes that our "willingness to refuse privilege to a restricted or restrictive cluster of metanarratives becomes a Canadian strategy for survival. We must, in Mikhail Bakhtin's terms, remain polyphonic" (357). History has, in its traditional forms, for too long "insisted [...] on a coherent narrative" (357). But since Canadians "cannot agree on what their meta-narrative is," Kroetsch insists, "in some perverse way, this very falling-apart of our story is what holds our story together" (355). Moreover, Kroetsch contends that "at the centre of any metanarrative is a traditional hero. Canadians, uncertain of their metanarratives, are more than uncertain of their heroes" (361). Unlike Australians, who remain doggedly eager to elevate their Anzacs to the realm of myth and heroism, Canadians have been notoriously famous for our lack of interest in heroes.

A number of other writers and historians have also noted the faltering Canadian narrative, and like Kroetsch, they regard it as desirable. When queried recently 
why Canada "does not have a foundational story for artists to tell," for example, Charles Foran suggested that "instead of possessing a strong cultural identity," we are an "experimental nation" that promotes "something different - a culture that is many cultures, many stories, in a place that stretches across a continent and is richly occupied" ("Searching"). Foran recalls Justin Trudeau's remark to the New York Times shortly after his election in 1915 that he was now prime minister of the "first postnational state": "There is no core identity, no mainstream in Canada" ("Searching"). Yet as Foran points out, Trudeau was merely echoing Marshall McLuhan's avowal half a century earlier: he declared then that "Canada is the only country in the world that knows how to live without an identity," a "condition" he did not regard "as a negative" ("Searching").

Nor does historian Charlotte Gray believe that "living without an identity" is a negative position. In the "Introduction" to her 2017 The Promise of Canada: 150 Years - People and Ideas That Have Shaped Our Country, she confesses that when she first immigrated to Canada [from England], she was "stunned to discover the wobbly sense of national identity" here. She then began to ask her "new compatriots" about what being "a Canadian" meant, but the replies she received were "often a stuttering medley of generalizations about what it did not mean (Canadian meant not being American, or British, or like residents of other former colonies such as Australia)" (xiii-xiv). Intriguingly, whereas Marilyn Lake writes that "there are now more books published on Australians at war than ever before, hundreds during the last two decades alone," and that "the shelves of bookshops groan under their weight and military history is usually given its own section of the shop" (14), Gray suggests that she has "acquired a bookshelf of titles" including The Search for Identity, On Being Canadian, What is a Canadian?, The Canadians, The Unfinished Canadian, and Nationalism without Walls: The Unbearable Lightness of Being Canadian (xiv). She claims to have found some hilarious definitions of Canadian definitions of Canadian identity in them, such as Peter C. Newman's quip, "This is the only country on earth whose citizens dream of being Clark Kent instead of Superman" (xiv)..$^{12}$ In line with Kroetsch and Foran, Gray notes that this country "defies definition. There is no master narrative for Canadian history: there are too many stories to package into a tidy, tightly scripted identity" (xiv). Gray applauds Canadians' lack of identity, advancing that it

exerts a sense of endless promise because over the years it has successfully managed so many competing pressures: parallel identities, layers of allegiance, deep-rooted hostilities, overlapping loyalties. This country has reimagined and embellished its self-image in every generation since the proclamation of the British North America Act in 1867, which means that each of those books has had a limited shelf life. (xiv)

Gray has also recently admitted that "it was moving to observe the centenary of the Battle of Vimy Ridge in 1917, but Vimy was not the most important military engagement that Canadians fought during the First World War, and the idea 
that it was the carnage at Vimy that constituted the birth of modern Canada is straight mythology" (F3). At the end of The Promise of Canada, she calls Canada "an unfinished and perhaps unfinishable project" (F3).

Recently, historian Erna Paris made a similar observation when she wrote that when Pierre Trudeau introduced his policy on multiculturalism to the House of Commons in 1971, his single most important statement "may have been that no singular culture could, or would, define Canada [...] in other words, that there would be no overriding cultural identity to assimilate to" ("Multiculturalism"). Trudeau then predicted that our famous lack of identity would become the root of our contemporary success in the world. Paris adds that it is this "deliberate looseness" that will "help to protect us," but only if we "remain vigilant" (O5), and apparently we have, as Canada remains a happy land that needs no heroes.

\section{Notes}

1 My title is a riff on a conversation that takes place between Galileo and his former student Andrea in Bertolt Brecht's play Galileo. Here, Andrea suggests that "unhappy is the land that breeds no her, but Galileo replies, "No, Andrea: unhappy is the land that needs a hero" (Scene Twelve, Galileo, 1938).

2 In "The Place of Anzac in Australian Historical Consciousness," historian Anna Clark records that the numbers of those who attend the Dawn Ceremonies are steadily increasing: "an estimated 50,000 attended the ceremony at Melbourne's Shrine of Remembrance in 2014" (Australian Historical Studies 48: 19).

3 A little-known aspect of Canadian history indicates that French-Canadians fought so well at the Battle of the Somme - in this case at in the northern French Village of Courcelette in September, 2016, that when British Commander Douglas Haig noticed what excellent fighters they were, he vowed, ironically, that "Canadians would be allowed to have a try at Vimy Ridge" ("Consciption Crisis").

4 In "'Dancing in the Sky': Billy Bishop Goes to War and Our Most Famous Canadian War Hero," Steve Lukits notes that "Canadians have a special place among the errant knights of the air. Of the 863 British Empire aces - those fighter pilots who shot down five or more enemy aircraft - Canadians number 171, and three of them are among the top ten" (Queen's Quarterly 124. 2: 201).

5 For a much longer examination of the many ways Australian women writers backed the attack, see my “"The Digger on the Lofty Pedestal': Australian Women's Fictions of the Great War" (Australian \& New Zealand Studies in Canada 10: 1-22). Several insubordinate women writers did manage to write against the grain, however. For further information on these writers' novels, see my "Guns 'n' Roses: Mollie Skinner's Intrepid Great War Fictions" (Southerly 59. 1: 105-121); and "Lesbia Harford's Homefront Warrior and Women's World War One Writing" (Australian Literary Studies 1. 5: 19-28). 
6 For information on how women writers deployed language against themselves, see my "(Not) Talking Back: Australian Women Novelists Lose the Great (Linguistic) War" (Australian Studies 18. 2: 179-206).

7 See my “"The Best Soldiers of All': Unsung Heroines in Canadian Women's Great War Fictions" (Canadian Literature 151: 66-99).

8 For an examination of how the depiction of soldiers in both Australian and Canadian women's and men's Second World War writing continues these same patterns, see my "War Writing in Australia, Canada, and New Zealand" in The Cambridge Companion to the Literature of World War II, ed. Marina MacKay, Cambridge University Press, 2009, 149-162.

9 According to Holbrook, "Australia is vastly outspending other combatant nations on commemorating the Great War centenary (50). Prime Minister Julia Gillard's declaration on the eve of Anzac Day that "the 2012-13 budget had allocated 83.5 million over seven years to funding initiatives relating to the Centenary of Anzac and the $100^{\text {th }}$ anniversary of the First World War" would seem to support Holbrook's claim. See also Marty Harris, "Funding the Centenary of Anzac." https://www.aph.gov.au/About_Parliament/Parliamentary_Department

10 Given these comments, it is surprising that Cook insists that "to link Vimy with peace is simply wrong, and to link peacekeeping with the memorial is utterly incoherent" (338-339).

11 According to reporter Randy Boswell, the French in France seemed to have lost their respect for the splendid Vimy Monument as well, having sullied the memory of the dead in 2009 by turning the parking lot into a place for cruising, swingers, and French citizens looking for kinky sex. See "Two Couples Convicted for Vimy Striptease" (National Post 9 April 2009: A2).

12 Gray has used this quip before, and I have followed her lead because it is such an appropriate comment on Canadians' famous lack of heroes.

\section{References}

“Australia's Conscription Debate, 1916-1917.” https://ww1.s..nsw.gov.au/stories/ australias-conscription-debate

Bailey, Matthew, and Sean Brawley. 2018. "Why Weren't We Taught? Exploring Frontier Conflict Through the Lens of Anzac." Journal of Australian Studies 42: 1: 19-33.

Bean, C. E. W., ed. 1916. The Anzac Book: Written and Illustrated in Gallipoli by the Men of Anzac. Melbourne: Cassell.

- 1934 [1921]. The Official History. The Story of Anzac: From the Outbreak of War to the End of the First Phase of the Gallipoli Campaign, May 41916. Vol. 1. Sydney: Angus and Robertson. 
Bethune, Brian. 2005. "It's Sublime and Deadly." Maclean's: 30-32.

Beynon, Francis Marion. 1988 [1919]. Aleta Dey. London: Virago.

Blackburn. Grace. 1930. The Man Child. Ottawa: Graphic.

Brookes, Mabel. 1917. Broken Idols. Melbourne: Melville and Mullen,.

Brown, Eric and Tim Cook. 2011. "The 1936 Vimy Pilgrimage." Canadian Military History 20. 2: 39.

Buitenhuis, Peter. 1987. The Great War of Words: British, American and Canadian Propaganda and Fiction, 1914-1933. Vancouver: UBC Press.

“Canadian National Vimy Memorial.” https://en.wikipedia.org/wiki/Canadian_National_Vimy_Memorial

Carrigg, David. 2017. "Tim Cook Examines Role of Vimy Ridge in Canadian Culture." https://vancouversun.com/entertainment/books/tim-cooki-examines-ro...

Clark, Anna. 2017. "The Place of Anzac in Australian Historical Consciousness." Australian Historical Studies 48: 19-34.

"The Conscription Crisis" http://www.cbc.ca/history/EPISCONTENTSE1EP12CH2PA3LE.html

“Conscription, 1917." https://www.warmuseum.ca/firstworldwar/history/life-athome-during...

Cook, Ramsay. 1970. "Nationalism in Canada or Portnoy's Complaint Revisited." South Atlantic Quarterly 69: 3-25.

Cook, Tim. 2017. Vimy: The Battle and the Legend. Canada, USA, UK, Ireland, Australia, New Zealand, India, South Africa, China: Penguin Random House Canada.

Everett-Green, Robert, 2017. "Vimy Ridge: Birthplace of a Nation - Or of a Canadian Myth?" https://www.theglobeandmail.com/news/national/battle-ofvimy-rid...

Freeman, Alan. "Canada's 'Disgrace' on Vimy Ridge.” http://www.network54. com/Search/view/57886/958412549/Canada's

Foran, Charles. 2016. "Searching for a Canada of the Soul, Not the Census." Toronto: The Globe and Mail F3.

Gerster, Robin. 1988. Big-Noting: The Heroic Theme in Australian War Writing. Melbourne: Melbourne University Press.

Gray, Charlotte. 2017. The Promise of Canada: 150 Years - People and Ideas That Have Shaped Our Country. Toronto: Simon and Schuster.

—. 2017 (30 December). "Canada 150: Anniversaries, the Enemy of Good History." The Globe and Mail: $\mathrm{O} 4$.

Grimshaw, Pat, Marilyn Lake, Ann McGrath, and Marian Quartly. 2006. "Giving Birth to the Nation." Creating a Nation, 1788-2007. Perth: API Network. 201-224.

Hamilton, Graeme. 2016. “"Breaking the Faith': Critics Angry Over Renaming of Vimy Ridge Park for Parizeau." National Post, Toronto: A3.

Hillmer, Norman. 2010. "The Canadian War Museum and the Military Identity of an Unmilitary People." Canadian Military History 20. 3: 19-26. 
Holbrook, Carolyn. 2017. “Adaptable Anzac: Past, Present and Future.” The Honest History Book. Ed. David Stephens and Alison Broinowski. Sydney: New South Publishing. 48-62.

How, Douglas. 1998. "A Literature of Stone.” Maclean's: 91.

Howells, Coral Anne. 1987. Private and Fictional Words: Canadian Women Novelists of the 1970s and 1980s. London: Methuen.

Hucker, Jacqueline. 2007. “'After the Agony in Stony Places': The Meaning and Significance of the Vimy Monument." Vimy Ridge: A Canadian Reassessment. Ed. Geoffrey Hayes, Andrew Iraocci, and Mike Bechtold. Waterloo: Wilfrid Laurier Press. 279-290.

Hughes, Robert. 1986. The Fatal Shore: The Epic of Australia's Founding. New York: Vintage.

Inglis, K. S. 1970. "The Australians at Gallipoli-II." Historical Studies 14: 363-367. Jenkins, Anthony. "Why It's Important to Reflect on Vimy." http:/v1.theglobeandmail. com/servlet/story/RTGAM.20070409.wevimy09/front/Front/Front

Kroetsch, Robert. 1997. "Disunity as Unity: A Canadian Strategy." New Contexts of Canadian Criticism. Ed. Ajay Hebele, Donna Palmateer Pennee, and T. R. Struthers. Peterborough, ON: Broadview Press. 355-365.

Lake, Marilyn. March 2006. "The Militarisation of Australian Historical Memory." Teaching History 40. 1: 15-16.

—. and Henry Reynolds, with Mark McKenna and Joy Damousi. 2010. What's Wrong with Anzac? The Militarisation of Australian History. Sydney: New South, University of New South Wales.

"The Legacy of Canada's WWI Conscription Crisis." http://montrealgazette.com/ feature/the-legacy-of-canadas-wwi-conscri...

Macintyre, Stuart. 1986 [1901-1942]. The Succeeding Age. Vol. 4. The Oxford History of Australia. Melbourne: Oxford University Press.

Mackenzie, Compton, 1929. Gallipoli Memories. London: Cassells.

Marlowe, Mary, 1918. The Women Who Wait. London: Simpkin Marshall Hamilton Kent \& Co.

McKernan, Michael. 1980. The Australian People and the Great War. Melbourne: Nelson.

McClung, Nellie. 1917. The Next of Kin: Those Who Wait and Wonder. Toronto: Thomas Allen.

McKay, Ian, and Jamie Swift. 2012. Warrior Nation: Rebranding Canada in an Age of Anxiety. Toronto: Behind the Lines.

-. 2016. The Vimy Trap: Or, How We Learned to Stop Worrying and Love the Great War. Toronto: Between the Lines.

Masefield, John. 1916. Gallipoli. London: Heinemann.

Montgomery, L. M. 1982 [1920]. Rilla of Ingleside. Toronto: Seal.

Morton, Desmond, and J. L. Granatstein. 1989. Marching Toward Armageddon: Canadians and the Great War 1914-1919. Toronto, Lester. 
Paris, Erna. 2018. "Canada's Multiculturalism Is Our Identity." The Globe and Mail: O5.

Reynolds, Henry. 2013. Forgotten War. Sydney: New South Publishing.

Richler, Noah. 2012. What We Talk About When We Walk About War. Fredericton: Goose Lane.

Rixon, Annie [Mrs. Richard de Clare Studdert]. 1940. Yesterday and Today. Sydney: Criterion.

Scarry, Elaine. 1987. The Body in Pain: The Making and Unmaking of the World. Oxford: Oxford University Press.

Scates, Bruce. 2006. Return to Gallipoli: Walking the Battlefields of the Great War. Cambridge: Cambridge University Press.

Selley, Chris. 2016. "Are We Really Any Good at This?" National Post: A8.

Serle, Geoffrey. 1965. "The Digger Tradition and Australian Nationalism." Meanjin Quaterly 24. 2: 149-158.

Sheftall, Mark. 2015. "Mythologising the Dominion Fighting Man: Australian and Canadian Narratives of the First World War, 1914-39." Australian Historical Studies 46: 1: 81-99.

Spears, Tom. 2017. "Harsh Reviews for Vimy Centennial." National Post: NP2.

Stevens, Paul, and John Saywell. 1983. Lord Minto's Canadian Papers: A Selection of the Fourth Earl of Minto, 1898-1904. Vol. 1. Toronto: The Champlain Society.

Swift, Jamie. 2015. “"How the Yearning for Peace after a Trench War's Horror Gave Way to Vapid 'Vimyism.' The Battleground of Remembrance: Struggles at the Intersection of Canadian War History and Public Memory." Canadian Issues Themes Canadiens: 36-39.

Thiessen, Vern. 2007. "Vimy." Canada and the Theatre of War: Eight World War One and Two Plays. Ed. Donna Coates and Sherrill Grace. Toronto: Playwrights Canada Press, 223-267.

Thompson, Nicole. 2015. "Looking Back at Vimy." Calgary Herald: B3.

Turner, Ian. 1974. "1914-1919.” A New History of Australia. Ed. F. K. Crowley. Melbourne: Heinemann. 312-356.

Valpy, Michael. "Setting a Legend in Stone." http://v.1.theglobeandmail.com/ servlet/story/RTGAM.20070407.wvi

—. "Vimy Ridge: The Making of a Myth." http://v1.theglobeandmail.com/servlet/ story/RTGAM.20070406.cover

Vance, Jonathan F. 2007. "The Making of Vimy." National Post: A21.

"Vimy Ridge Day in Canada." https://www.timenddate.com/holidays/canada/ vimy-ridge-day?hc loc...

Walker, Shirley. 1985. "The Boer War: Paterson, Abbott, Brennan, Miles Franklin and Breaker Morant." Australian Literary Studies 12: 207-222.

Walsh, Michael J. K., 2017. "Then In 1915: Eric Bogle's 'And the Band Played Waltzing Matilda." Journal of Australian Studies 41. 2: 237-251. 
Weinreb, Arthur. 2002. "Vimy Vidi Vichy." http://canadafreepress.com/2002/ weinreb91602.htm

Wise, Syd. 1985. Australian Journal of the War Memorial 7: 3-11. 


\author{
Martin Löschnigg \\ (iD https://orcid.org/0000-0003-1330-7880 \\ University of Graz
}

\title{
How to Tell the War? Trench Warfare and the Realist Paradigm in First World War Narratives
}

\begin{abstract}
This paper will analyze how memoirs and novels of the First World War reflect the challenges which modern warfare poses to realist narrative. Mechanized warfare resists the narrative encoding of experience. In particular, the nature of warfare on the Western Front 1914-1918, characterized by the fragmentation of vision in the trenches and the exposure of soldiers to a continuous sequence of acoustic shocks, had a disruptive effect on perceptions of time and space, and consequently on the rendering of the chronotope in narrative accounts of the fighting. Under the conditions of the Western Front, the order-creating and meaning-creating function of narrative seemed to have become suspended. As I want to show, these challenges account for a fundamental ambivalence in memoirs and novels which have largely been regarded as paradigmatically 'realistic' and 'authentic' anti-war narratives. Their documentary impetus, i.e. the claim to tell the 'truth' about the war, is often countered by textual fragmentation and a "cinematic telescoping of time" (Williams 29 ), i.e. by a structure which implies that such a 'truth' could not really be articulated. In consequence, these texts also explore the relationship between fact and fiction in the attempt at rendering an authentic account of the modern war experience. My examples are Edmund Blunden's Undertones of War (1928), Robert Graves's Goodbye to All That (1929) and the novel Generals Die in Bed (1930) by the Canadian Charles Yale Harrison, as well as German examples like Ernst Jünger's In Stahlgewittern (1920; The Storm of Steel, 1929), Ludwig Renn's Krieg (1928; War, 1929) and Edlef Köppen's Heeresbericht (1930; Higher Command, 1931).
\end{abstract}

\section{The Ambiguity of First World War Narratives: Disorientation Versus the Claim Towards Authenticity}

Comparing the books written about the Spanish Civil War to those from the war of 1914-1918, George Orwell remarked:

[...] the books about the Great War were by common soldiers or junior officers who did not even pretend to understand what the whole thing was about. Books 
Like All Quiet on the Western Front, Le Feu, A Farewell to Arms, Death of a Hero, Good-Bye to All That, Memoirs of an Infantry Officer and A Subaltern on the Somme were written not by propagandists but by victims. They are saying in effect, 'What the hell is all this about? God knows. All we can do is to endure. (108; original emphasis)

Orwell rightly saw that disorientation and stoic acceptance set the tone in many First World War narratives. However, these works also make an emphatic claim towards telling the 'truth' about the war, which clearly contradicts notions of passivity and utter bewilderment. This claim was of eminent importance with regard to interpretations of the war experience and their ideological significance in the political context of the 1920s and early 1930s. In Germany in particular, the struggle for political dominance in the Weimar Republic comprised a battle over interpreting the war between bellicist young nationalists like Ernst Jünger or Werner Beumelburg on the one side, and pacifists like Remarque, Ludwig Renn or Edlef Köppen on the other (cf. Bornebusch; Brückner; Travers). Struggling for sovereignty of interpretation, authors attempted to testify to their experience of the war and mediate between the world of the frontline and the contemporary experience of their readers. They were thus propagandists after all, besides victims, if maybe not in the straightforwardly political sense implied by Orwell. No matter how contrary their ideological intentions were, however, their attempt at conveying their individual image of the war to their readers relied on 'realistic' representation, and thus on a mode of writing that conveys notions of structure, purpose and agency rather than aimless disorientation. Considering Orwell's pronouncement, there is thus a profound ambivalence in First World War narratives which derives from the fundamental contradiction between a sense of helplessness and "passive suffering" on the one hand, and the claim (often explicitly expressed) towards 'authenticity' and 'truthful' testimony on the other.

In this essay, I want to show, upon the example of selected British, Canadian and German war memoirs and autobiographical novels, how the troubled question of 'authenticity' or 'truthfulness' with regard to First World War narratives must also be asked before the challenges which modern warfare poses to realist narrative. Mechanised warfare resists the narrative encoding of experience. In particular, the nature of warfare on the Western Front 1914-1918, characterised by the fragmentation of vision in the trenches and the exposure of soldiers to a continuous sequence of acoustic shocks (cf. Leed 126-131), had a disruptive effect on perceptions of time and space, and consequently on the rendering of the chronotope in narrative accounts of the fighting. Jan Mieszkowski has characterised the First World War as a total war which "no longer respect[ed] epic conventions of time, space and pacing" but which was "distinguished [instead] by radical discontinuity, as if with each subsequent day, hour, or minute the 
proceeding began anew with no regard for what had taken place" (152). Indeed, it seemed that under the conditions of the war, and especially those of the war on the Western Front, the capacity of narrative to create order and meaning had been suspended: "A writer might experience the war, [but] he could not put his experience into a narrative form - a story with causal connections, direction, and a resolving ending - because that would give it the significance it did not possess, or did not reveal" (Hynes 106).

Trench fighting undermined important parameters of realist narrative: spatial orientation, linear chronology, causality, teleology and the assumption of a transparency of language with regard to its referential objects. The disintegration of these parameters is a vital factor contributing to the ambivalence in war memoirs and novels mentioned above, countering as it does those elements and techniques which effect coherence and a sense of purpose, and which are thus significant for the authentification of the narrative. These are, first, an emphasis on historical facticity (also in novels) which suggests a purely mimetic function, avoiding the impression of any attempts at ideological manipulation; second, the authority of direct experience established by the testimony of the écrivain combatant and, finally, the very 'plain style' of war narratives. These 'authentification devices' have helped to produce powerful cultural imaginaries, in particular the phenomenon which James Campbell has called "combat gnosticism," i.e. the privileging of the frontline fighter's perspective as the only 'true' perspective on the war, to the marginalization or even exclusion of others. A memorable example, which also illustrates the importance of plain style as an 'authentication device,' is the presumed identity of author, first-person narrator and protagonist in Ludwig Renn's Krieg (1928). "Renn" is a private soldier, and the text accordingly renders a private's perspective. However, "Ludwig Renn" was the pseudonym of Arnold Friedrich Vieth von Golßenau, who came from a Saxon aristocratic family and served in the war as an officer. The case of Renn/von Golßenau is instructive not only because of its emphasis on autoptic experience, including the implication that the perspective of the ranks (from 'below') provided the most representatively 'authentic' depiction of the frontline, but also because of its blurring of the boundaries between factual memoir, as signalled by the proffered "autobiographical pact" (Lejeune), and fiction. However, these boundaries must also appear as permeable because of the co-existence of contradictory elements in Great War narratives, namely disorientation $v s$. a representationally constituted 'truth claim,' a co-existence which hindered 'storification' in the sense of a causally and teleologically founded arrangement of narratemes. Conversely, the infringement or even disintegration of the 'realist paradigm' and of concomitant forms of emplotment enhanced the experiential dimension of narratives, i.e. the sense of a re-enactment rather than a coherent re-structuring post festum of fragmented and chaotic experience.

In the following, I want to look at the aforementioned parameters of realist narrative (narrated space, time, agency, and semantic transparency) and discuss 
the impact that epistemological and psychological factors of trench warfare might have on them. My focus will be on the aesthetic and structural consequences this impact had for renderings of the war experience in (fictionalized) autobiographical writings of the First World War - consequences ranging from narrative fragmentation and 'filmic' montage to the emulation of theatrical farce. I am therefore concerned not with the socio-cultural sense making of trench warfare, but with its narratology. This is why I have chosen works that are consciously literary, as it were, and which indicate that their authors agonized over issues of representation, even if this means moving on well-trodden ground in the case of canonical writers like Aldington, Blunden, Jünger or Graves. The fact that these works were written by "junior officers" (in Orwell's phrase) is primarily relevant not with regard to differences between their war experience and that of the ranks (indeed, these hardly existed when it comes to the experiential parameters of trench warfare outlined here), but mainly with regard to their 'literary awareness.' They had come to the frontline as nascent (and sometimes already published) writers with literary ambitions - well-educated volunteers, in any case, who had read much literature. Struggling for a style to express their experience of a war that was in many ways so different from everything they had read and heard about war, they scrutinized the literary tradition (including that of 'realist' writing); they turned against that which appeared inadequate and adopted what might be useful. My argument is that the experiential conditions of trench fighting engendered a re-living rather than a re-telling of experience in their retrospective accounts (all written at the distance of at least a decade from the events). The dynamics of such a re-living are manifest on the aesthetic and structural levels of these works, relativizing notions of the creation of meaning, from a temporal distance, in 'epic' form.

In her ground-breaking book on Representing War (1993), Evelyn Cobley analyses narrative techniques in First World War novels to show how "modes of representation generate critiques of the war which nevertheless remain complicitous with the Enlightenment values which the experience of war can do nothing but undermine" (3). She thus perceives a fundamental discrepancy in the novels between their subject matter and the rationalizing, explicatory functions of some of their narrative techniques. Unlike Cobley, I am not primarily interested in the ideological implications (and contradictions) conveyed by narrative structures, but in their psychological significance (i.e. in the way they reflect the conditions of the front as a psychological space), and in narrative as a cognitive instrument for 'framing' the trench experience. Relating to basic perspectives on human experience, cognitive frames become functional in the mediation of that experience in narrative discourse. In this sense, the narrative reliving of the front line in (autobiographical) accounts may be grasped in terms of the frame models proposed by cognitive narratology (see, for instance, Fludernik): while trench fighting tended to disrupt 'telling frames' dependent on parameters like chronology, causality and teleology, the 'experientiality' of First World War narratives might be enhanced 
through the fragmentation of the chronotope and (in homodiegetic narratives) the blurring of boundaries between experiencing and narrating selves. These strategies emphasize a continuity of experience and narration despite the time-lag of the narrative act itself. As I shall try to show, narratological analysis may thus add important facets to a psycho-historical understanding of Great War narratives and their modernity, as well as to the still troubled issue of their 'authenticity.'

\section{The Realist Paradigm and Its Disruption by the Trench Experience: Narrated Space, Time, Agency, and Semantic Transparency}

In spatial terms, trench fighting along most of the Western Front was characterised by fragmentation and a resulting visual and cognitive particularity. While the sites of battle had greatly extended, the individual soldier's range of movement and vision were extremely limited. The visual limitations could only partially be compensated by the use of periscopes and aerial photographs, the latter being normally available only to the staff behind the lines. ${ }^{2}$ The enemy, too, remained invisible most of the time: "As for men, they were seldom to be seen. For this was the peculiarity of the Western Front: The uproar seldom ceased and the number of men involved was countless, but the terrain seemed deserted" (Wolff 34). The resulting feeling of disorientation, and the impression that the fighting had come loose from the spatial coordinates of human action, are memorably expressed in Richard Aldington's Death of a Hero:

The fighting was so impersonal as a rule that it seemed rather a conflict with dreadful hostile forces of Nature than with other men. You did not see the men who fired the ceaseless hails of shells on you, nor the machine-gunners who swept away twenty men to death in one zip of their murderous bullets, nor the hands which projected trenchmortars that shook the earth with awful detonations, nor even the invisible sniper who picked you off mysteriously with the sudden impersonal 'ping!' of his bullet. (292)

This 'impersonal' dimension of the fighting is also emphasised in the following passage from Ernst Jünger's In Stahlgewittern (The Storm of Steel). Arriving at the frontline, Jünger's unit is for the first time exposed to artillery fire:

Das war so rätselhaft, so unpersönlich. Kaum, dass man dabei an den Feind dachte, dieses geheimnisvolle, tückische Wesen irgendwo dahinten. Das völlig außerhalb der Erfahrung liegende Ereignis machte einen so starken Eindruck, dass es Mühe kostete, die Zusammenhänge zu begreifen. (9)

This was so enigmatic, so impersonal. One hardly thought about the enemy in connection with it, this mysterious, insidious being somewhere back there. The occurrence, which was so completely beyond our experience, created such a strong impression that one was at pains to comprehend the connections. (trans. M.L.) 
The spatial deictics in this passage ("irgendwo dahinten," "außerhalb") signify that which is beyond reach, physically and cognitively: the unknown or even uncanny. The inability to locate phenomena, literally and figuratively, as expressed in this passage, creates uncertainty and fear.

In a similar manner, yet with a different tone and emphasis, Edmund Blunden, in his Undertones of War, refers to the spatial fragmentation and resulting lack of a wider knowledge that characterised the soldiers' experience. Like Jünger, however, Blunden makes it clear that it was difficult or even impossible for soldiers to 'get a larger picture,' literally and in the sense of a contextualised understanding of their situation: "What the infantryman in France knew about the war as a whole was seldom worth knowing, and we had little time or taste for studying the probable effect upon us of events beyond the skyline of immediate orders" (149).

The scarcity of visual points of orientation along the frontline, its spatial fragmentation and the corresponding disorientation of the soldiers, especially also in a figurative sense, was counterbalanced by an equally disorienting intensification of acoustic stimuli, an "uproar [that] seldom ceased," as Leon Wolff has it (34). When asked to describe the acoustic sensorium of the frontline, Robert Graves famously replied: "[Y] $]$ ou can't communicate noise. Noise never stopped for one moment - ever" (qtd. in Fussell 170). During protracted bombardments in particular, this continual exposure to acoustic shocks, together with the enforced passivity of the trench fighter, was liable to create extreme mental strain, as is underlined by Aldington, whose attempt to render the pandemonium of intensive shelling must needs take recourse, it seems, to onomatopoeia:

ZWiiiNG, CRASH, CLAAANG!

Minute after minute, hour after hour, day and night, week after week, those merciless heavies pounded the groaning town.

ZWIING, CRASH! CRAASH! CLAAANG!

It was too violent a thing to get accustomed to. The mere physical shock, the slap in the chest, of the great shells exploding close at hand, forbade that. They became a torment, an obsession, an exasperation, a nervous nightmare. (343)

During these situations, the spatial experience of the soldier wavered between extreme concentration, as he was doomed to immobility, and indeterminacy, as vision was largely precluded and the intensity of acoustic perceptions made it impossible to locate their origin. Since the First World War, the growing mechanization of battle and increasing spatial and quantitative delimitation of warfare have further heightened this fragmentary character of the individual war experience. Literary renderings of the spaces of modern battles therefore tend to be characterised by extremely disproportionate relations between the components of Elisabeth Ströker's tripartite model of narrative spaces, "gestimmter Raum" (emotionally determined space), "Aktionsraum" (action space) and "Anschauungsraum" (perception space) as constituted by the feeling, acting and perceiving 
subject. In the excerpts quoted above, emotionally charged 'space' is heavily dominant, while perception and action are severely limited. The fragmentation of spatial unity into multiple, disconnected (and disproportionate) spaces resists the narrative rendering of "embodied space" (de Certeau 115), that is, of space as a location where human experience and consciousness take on material form, as topographical places acquire meaning according to the actions of those who inhabit them. In terms of Michel de Certeau's theory of lived space, spaces are "practised places," since "space occurs as the effect produced by the operations that orient it, situate it, [and] temporalize it" (117). Orientation and situation (in the sense of a meaningful positioning through action) were hindered by the phenomenology of trench warfare, and the same applies to the temporalizing of inhabited spaces.

Even more so than the fragmentation of space, it was the disruption of a sense of time which worked against narrativising the frontline experience in terms of conventional realist narrative. Human experience is time-bound and, according to Paul Ricoeur's model of mimetic levels as described in Time and Narrative, experience itself is narratively (pre-) structured (cf. Ricœur 105-162: "Temps et récit: la triple mimesis"). In autobiographical discourse in particular, this timeboundedness correlates with the temporality of narrative. Modern warfare disrupts this nexus. It does so by imposing 'machine time' on human action and reaction, eradicating an individual sense of time. Mechanised warfare on the Western Front represented a negative version of the industrial process, as it were, with soldiers functioning as 'workers of destruction.' Analogically, the regulated machine-time of industrialised warfare, symbolised by the synchronization of watches among officers, eliminated 'individual timing,' thus constituting a monumental intrusion into human experience.

Typically along the Western Front, long 'empty' stretches of time spent in waiting or routine, alternated with extremely compressed moments of combat. The latter is rendered for instance in Blunden's Undertones ("Time went by, but no-one felt the passage of it, for the shadow of death lay over the dial," 169) and Aldington's Death of a Hero: "For Winterbourne the battle was a timeless confusion, a chaos of noise, fatigue, anxiety, and horror. He did not know how many days and nights it lasted, lost completely the sequence of events, found great gaps in his conscious memory" (376). At another point in Aldington's novel, however, George Winterbourne comes to feel that "[t]ime, like a torture, seemed infinitely prolonged" (303). The abstract, discontinuous time-structure of the battlefields prevented meaningful chronological orientation, causing soldiers to lose hold of their own sense of time and space. As a result, it also tended to deprive them of a sense of individuality and of their own significance:

He had forgotten the element of waiting, the deliberation necessary in moving vast masses of men about, which made the slow, ruthless movement of the huge war machine so inexorable. You hung about, but inevitably you moved, your tiny little cog 
was brought into action. And this, too, was strangely impersonal, confirmed the feeling of fatalism. It seemed insane to think that you had any individual importance. (294)

Similarly, in A Man Could Stand Up, the fourth part of Ford Madox Ford's Parade's End tetralogy, Tietjens muses on the

[...] process of the eternal waiting that is War. You hung about and you hung about, and you kicked your heels and you kicked your heels: waiting for Mills bombs to come, or for jam, or for generals, or for the tanks, or transport, or the clearance of the road ahead. You waited in offices under the eyes of somnolent orderlies, under fire on the banks of canals, you waited in hotels, dug-outs, tin sheds, ruined houses. There will be no man who survives of His Majesty's Armed Forces that shall not remember those eternal hours when Time itself stayed still as the true image of bloody War. (569)

The specific time structures of trench warfare resisted the chronological structuring required in order to express experience in a narrative form (cf. Hüppauf, esp. 209, 219-221). In many First World War narratives, therefore, we find attempts at rendering the fragmented chronotope of the front through syntactic fragmentation, ellipsis and onomatopoeia on the one hand, and a characteristic form of the iterative on the other.

According to David Williams, many literary representations of the First World War are "governed largely by the implicit epistemology of film" (30), rendering a "cinematic form of memory" (6) which causes the past and the present to collapse in a "cinematic telescoping of time" (29). This modern technique characterises for instance the Canadian Charles Yale Harrison's Generals Die in Bed (1930). Harrison's novel disintegrates 'realist' chronology by using the present tense in a manner that emphasises an iterative rendering of events:

Endlessly in and out. Different sectors, different names of trenches, different trenches, but always the same trenches, the same yellow, infested earth, the same screaming shells, the same comet-tailed 'minnies' with their splintering roar. The same rats, fat and sleek with their corpse-filled bodies, the same gimlet eyes. The same lice which we carry with us wherever we go. In and out, in and out, endlessly, sweating, endlessly, endlessly [...]. (27)

Similarly, Ernst Jünger's fictionalised war diary In Stahlgewittern focuses on typical military actions of limited scope. There is no consistent chronological structuring, even if the chapter headings (mostly referring to the scenes of Jünger's deployment) provide a rough chronology, and individual events are often precisely dated. Instead, recurring situations are thematically summarised as typical battle action sequences (cf. Müller 222) or trench routine: "Das Leben im Graben war streng geregelt; ich zeichne hier den Verlauf eines Tages auf, wie achtzehn Monate 
hindurch einer dem anderen folgte [...]" (45) ["Life in the trenches was strictly regulated; I here record the events of a day much like those which followed it, one upon another, during eighteen months [...]"; trans. M.L.]. In turn, the chaos of battle is rendered through a clipped, cinematic style. This also applies to the following description of an attack in Edlef Köppen's novel Heeresbericht (1930):

Wie der letzte Rauch sich vom Boden gelöst hat, steht und liegt und kniet und kriecht und läuft und springt, graue lebendige Masse; der Feind. Und stürmt, Handgranaten hochgeschwungen, das Bajonett gereckt, gegen den Graben vor.

Da kläfft das Maschinengewehr neben Reisiger los. Da prasselt neben ihm Schnellfeuer aller Gewehre.

Herrgott, was geschieht! Dutzende von Franzosen werfen die Arme hoch und fallen rücklings zur Erde. Aber andere Dutzende dicht geballt drängen weiter vorwärts.

Die Feuer der Handgranaten zischen. Die Flammen der Artillerie rasen. Und: Franzosen, immer wieder neu: Franzosen: vorwärts.

Am Maschinengewehr schreit man durcheinander. Reisiger begreift kein Wort. (79-80)

As soon as the last of the smoke has lifted from the ground there stands and lies and kneels and creeps and runs and jumps, grey living mass; the enemy. And storms, hand-grenades wielded high, bayonets pointing, against our trench.

Then the machine-gun beside Reisiger starts barking. Then beside him rapid fire from all rifles is pattering.

Good God, what's happening! Dozens of Frenchmen throw up their arms and fall backwards onto the ground. Yet dozens of others continue to press forward, tightly clustered.

The blasts of the hand-grenades are hissing. The flames of the artillery are racing. And: Frenchmen, always new Frenchmen: advance.

At the machine-gun there is confused shouting. Reisiger does not understand a single word. (trans. M.L.)

Koeppen achieves immediacy through the use of the present tense, and extreme concentration through the paratactic style, parallelism and the use of polysyndeton that characterise the passage. Similar passages abound in the novel, as well as in Jünger and Renn. In the following example from Renn's Krieg, the added use of onomatopoeia to render the noise of battle emphasises the bewildering simultaneity of sensory impressions:

S! S! Ss! fuhren die Gewehrkugeln immer näher.

Sch-pramm! Granaten hinter uns. Wir mußten gleich auf der Höhe sein und duckten uns. Rechts stand ein Geschütz auf der Höhe. Kanoniere schleppten Munition, schossen. Bramm! Bramm! Schwarze Wolken rings darum. Ein Mann wurde wie aufrecht nach hinten verschoben.

Vor uns schrie jemand: "Nicht einschieben! Wir liegen schon in drei Reihen hintereinander!" 
S! S! Sch! - Preng, pamm! Rammss! krachte, zischte, zirpte es. Die Franzosen lagen wahrscheinlich dicht hinter der Höhe. (64)

S! S! Ss! The bullets swished by closer and closer.

Sch-pramm! Shells behind us. We were surely close to the top and crouched down. On the right, there was a gun positioned at the top. Gunners dragged ammunition, fired. Bramm! Bramm! Black clouds around it. A man was shifted backwards as if upright. In front of us, someone shouted: "Don't press forward! There are three rows of us already, one behind the other!"

S! S! Sch! - Preng, pamm! Rammss! it cracked, hissed, zinged. The French were probably right behind the ridge. (trans. M.L.)

In the following passage, narrative sequentiality and coherence seem to have been abandoned altogether in favour of a fragmented and quasi-simultaneous rendering of loosely connected associations and sense perceptions. Largely eliminating the mediating voice of realist narrative, the passage instead approaches an immediate rendering of events as reflected by an experiencing consciousness. This impression is further enhanced by the line breaks, which produce a staccato reminiscent of some of the German expressionist poetry, notably that of August Stramm, that was written during the war (cf. Löschnigg 116-123), while the plastic rendering of sense impressions and the 'explosive' dynamics of the scene evoke Ludwig Meidner's foreshadowing of wartime destruction in his paintings of Apocalyptic Landscapes (1912). In any case, we are far removed here from the sequential order of realist narrative:

\author{
Ramm! App! Ramms! Karr! \\ Der Angriff mußte mißglückt sein! \\ Steinstückchen flogen umher. \\ Ich duckte mich tiefer ins Loch. \\ Was tut nur Hänsel noch draußen? \\ Es krachte und krachte, bald näher, bald ferner. \\ Graue Wolken von Einschlägen trieben über uns weg. \\ Es roch immer stärker nach Pulver. (216) \\ Ramm! App! Ramms! Karr! \\ The attack must have failed! \\ Chips of rock whizzed about. \\ I crouched deeper into the hole. \\ What is Hänsel still doing out there? \\ There was cracking and booming, now nearer, now more distant. \\ Grey clouds from impacts floated above us. \\ The smell of powder grew stronger and stronger. (trans. M.L.)
}

What needs to be emphasised about this passage is the fact that the narrating subject has largely been eclipsed by the object world, the 'I' being reduced - 
except for one sentence reporting external action - to sense impressions and disconnected fragments of consciousness. The passage thus renders the loss of individual agency in face of the impersonal dynamics of the war machine. As Santanu Das has stated, "[t]he conjunction of underground trench warfare and industrial weaponry severed the link between space, vision, and danger which had been used to structure perception in conventional warfare: life now depended on the arbitrary direction of a shell, robbing the soldiers of any sense of agency or purpose" (75). The 'soundscape' produced by the massive deployment of high explosives and the 'emptiness' of the battlefield created the impression that the war had acquired a dynamic of its own. Due to its overwhelming scale, soldiers had very little or no knowledge of the larger connections of their actions, feeling like cogs in a giant machine: "Es war seltsam, zu erfahren, daß unser scheinbar wirres Tun in finsterer Nacht [...] dazu beigetragen [hatte], den mit so mächtigen Kräften begonnenen Angriff zum Stillstand zu bringen" ["It was curious to learn that our seemingly chaotic action in the dark of the night had contributed to stopping an enemy advance that had begun with such great force"; trans. M.L.], is what Jünger writes about his participation in the Third Battle of Ypres in 1917 (179). According to the testimony of memoirs, novels and other literature, soldiers in the Great War often seem to have felt that they were confronted (and killed) by powers they did not understand or, in Orwell's words, did not "even pretend to understand" at all.

Depriving the soldiers of agency, the disorientation and enforced passivity of the war experience undermined the position of the narrating subject, counteracting the causal and teleological structuring of narrative. Edmund Blunden, for instance, explicitly states that "the experience to be sketched in [Undertones of War] is very local, limited, [and] incoherent" ("Preliminary," xli). Accordingly, the structuring of the book opposes conventions of realism. There is, of course, the typical sequence from arrival at the front and initiation into the realities of trench fighting to the first major battle, yet beyond this, there is no configuration of events, i.e. no 'plot' or arc of suspense, no central conflict, no recognizable chain of causal connections. Instead, many of the episodes appear 'randomly' placed and exchangeable, 'pictures' or 'vignettes' rather than sequentialised elements in the trajectory of a chronologically structured narrative. ${ }^{3}$ However, this lack of a plot carries within itself its own meaning, reflecting as it does the incoherence of the war experience itself, and of its memories. Indeed, Blunden may have felt that emplotment would have signified a retrospective attribution of meaning which the experience itself seemed to deny (cf. Erll 197). The characteristic lyricism of Blunden's memoir (and also, at times, of Sassoon's Sherston trilogy) thus serves not only the creation of strongly ironic contrasts with the author's subject matter, but must also be seen, under different auspices, as an implicit rejection of a conventionally realistic narrativizing of the war experience. ${ }^{4}$ 
My last point is language: the realist paradigm includes, as one of its fundamental elements, the assumption of the referential function and transparency of language with regard to extra-linguistic reality. This element, too, was called in doubt by the war, as it seemed that "[t]raditional language and vocabulary were grossly inadequate [...] to describe the trench experience" (Eksteins 218). Remembering the frontline, Ford Madox Ford noted how he sometimes found it impossible to render his memories in words:

Today [...] simply to read 'Ploegsteert' or 'Armentières' seems to bring up extraordinarily coloured and exact pictures behind my eyeballs $[\ldots]$ of men, burst into mere showers of blood and dissolving into muddy ooze [...]. But, as for putting them - into words! No: the mind stops dead, and something in the brain stops and shuts down. $(1999,37)$

Herbert Read wrote in his memoir of the war, significantly entitled The Contrary Experience, that there seemed to be between combatants and civilians "a dark screen of horror and violation: the knowledge of the reality of the war. Across that screen I could not communicate. Nor could any of my friends, who had had the same experience" (217). On the other side of the screen, too, it was felt that soldiers were undergoing what non-combatants could not comprehend. Thus, Vera Brittain noted in her Testament of Youth that the war placed "a barrier of indescribable experience between men and the women whom they loved. [...] Quite early I realized [the] possibility of a permanent impediment to understanding" (143). In war novels, too, the feeling that the war experience could not be communicated through words became a pervasive topos. In Remarques Im Westen nichts Neues, Paul Bäumer comes to realise that the war experience cannot really be told ("[kann] nicht erzählt werden") (119). Similarly, the protagonist in Köppen's Heeresbericht has to break off when asked by civilians to "tell them a little about the war" ("mal ein bißchen aus dem Krieg [zu erzählen]"): "[...] schon abgebrochen die Erzählung. Was wissen sie, was Krieg heißt! Was wissen sie, was schießen heißt. [...] was wissen sie, was eine Granate ist?" (51) ["[...] the account broken off already. What do they know what war means! What do they know what shooting means! [...] what do they know what a shell is?"; trans. M.L.]. Trying to find words for unprecedented experience, writers often took recourse to metaphor, i.e. 'non-transparent' figurative language. This is illustrated by Blunden's description, with an added comment on the time gap and difficulty involved, of heavy guns as "tremendous iron engines, with gaping mouths; standing behind, if you could keep your eyes unblurred at the titanic sound of their speaking, you could see their mortal monosyllables of inferno climbing dead straight into the sky. But these metaphors occurred later" (151). ${ }^{5}$ 


\section{Theatricality, Fragmentation and Montage: Robert Graves's Goodbye to All That and Edlef Köppen's Heeresbericht}

In the following, I want to look briefly at two First World War narratives that illustrate very memorably the impact of the war experience on narrative discourse: Robert Graves's Goodbye to All That and the already quoted Heeresbericht by Edlef Köppen, published in 1929 and 1930 respectively. Goodbye, surely one of the best-known English accounts of the war, is a stylized, literary memoir that has been referred to as a "semi-fictional autobiography" (cf. Broich), while Heeresbericht is a novel with strong autobiographical elements, firmly rooted in the author's autoptic experience of the front line. It is perhaps one of the most remarkable novels of the war, even if still relatively little known. ${ }^{6}$ An English translation, now practically impossible to come by, appeared in 1931 under the title Higher Command (literally, the title means 'Military Communiqué').

At the beginning of Goodbye, Graves assures the reader of the authenticity of his account when he points to his "readiness to accept autobiographical convention" (9) and thus to fulfil the "autobiographical pact" (Lejeune). However, we learn about the war sections of the book that they were originally conceived of as a novel: "In 1916, when on leave in England after being wounded, I began an account of my first few months in France. Having stupidly [!] written it as a novel, I have now to re-translate it into history" (79). This is not Graves's final say on the generic status of his text, though. Later in the book we read: "I made several attempts [...] to rid myself of the poison of war memories by finishing my novel, but had to abandon it - ashamed at having distorted my material with a plot, and yet not sure enough of myself to turn it back into undisguised history" (262). Graves's discomfort with a plot is noteworthy: structure, chronology and causality must have appeared inadequate to rendering 'authentically' the fragmentary and chaotic nature of the war. As a result, the war part of Goodbye consists of a sequence of loosely connected episodes, many of them anecdotal and intensively dramatized. The short, theatrically 'staged' episodes introduce stereotypical figures like sadistic drill sergeants or dotty colonels. Martin Seymour-Smith, Graves's first biographer, notes that the book is not "composed" (192), and that the lack of composition is an indication of straightforward factual accuracy. In contrast, Paul Fussell (203-220) regards the book as very consciously constructed, even contrived, yet not in the sense of the plotting of realist novels. Rather, Fussell speaks of "The Caricature Scenes of Robert Graves" and points to their indebtedness to the comedy of humours. ${ }^{7}$ As it seems, Goodbye is characterised by a profound ambivalence. On the one hand, Graves's theatricality and recourse to literary models subtly relativise the non-fictional status of his narrative. On the other hand, it appears as if he avoided giving narrative structure to the chaotic, feeling that the mise en scène of the fragmentary and exaggerated was the only way of maintaining a claim towards a 'truthful' account of the war. 
To tell the 'truth' about the war is the expressed aim of Köppen's Heeresbericht. The novel portrays its protagonist's progress from an enthusiastic volunteer to a conscientious objector locked up in a mental institution. Adolf Reisiger's name echoes the late medieval word for a 'rider' or mounted warrior, but is also reminiscent of Karl Philipp Moritz's Anton Reiser, a prototypical novel of development and estrangement from the late eighteenth century. For Köppen's protagonist, in many ways the author's alter ego, the war becomes an "education in disgust" (Trotter 40), typical of the anti-war novels of the late 1920s and early 1930s, and to pacifism. Heeresbericht thus represents a 'negative Bildungsroman,' a story about social alienation through the war experience as it is also expressed in the title of Graves's Goodbye to All That.

In a detached tone, and through narrative fragmentation and montage, Köppen confronts episodes from the war experience of his protagonist with excerpts from documents like communiqués and reports, statistics, newspaper articles and political speeches. He thus explores the discrepancy between the realities of the frontline and the media images, between 'authentic,' individual experience and the totalizing and abstracting views of politicians and generals; above all, however, he underlines the necessity of seeing through the manipulation of attitudes in the public discourse. Köppen's anti-war novel critiques the 'monopoly of interpretation' exercised by those in power, correcting the propaganda by means of an individual account, a 'private' military communiqué. The juxtaposition and interaction of the fiction and the documentary sources create a paradoxical effect: as Reisiger's story unmasks the ideological distortions of the 'truth' in many of the documents, the reader comes to accept that story as the deeper 'truth' about the war. The authentic sources thus support in the negative, as it were, the fiction's claim to authenticity.

While Graves is theatrical, Köppen is filmic. In addition to the cinematic effects of montage, the present tense in the narrative parts creates 'filmic' immediacy; also, the narrative renders multiple perspectives, which function as different 'lenses' on the events (cf. Schwering). Filmic analogies become explicit in an episode dealing with Reisiger's leave, which brings home the gulf between civilians and the front. Back to the war, memories of home unwind before his eyes like a film, "zu schnell gedreht, ungeschickt geschnitten, [...] zu Bildchen, zu Fetzen zerrissen" (148) ["too hastily shot, clumsily cut. [...] torn to stills, to fragments"; trans. M.L.]. As the narrative re-enacts a film tear, the significance of the cinematic style for the novel's themes is drastically emphasised: like a film collapsing, meaning-creating structures break down in the war: "Nur Verstehen gibt es nicht mehr, gibt es nicht mehr. [...] Der Motor hakt, röchelt, spuckt, setzt aus" (52) ["There is no more understanding, just no more understanding. [...] The engine jolts, gasps, spits, stalls"; trans. M.L.]. Köppen's novel resembles the kind of 'flash fiction' also represented by Willliam March's Company $K$ (1933), with its short testimonies by 113 narrators presented in chronological order. Both novels are 
deliberately 'modernist' and metafictional. In any case, Köppen's novel is more modern in style and technique than my other examples, yet these too clearly indicate the challenges mechanised warfare presented to traditional modes of narrative.

Emphasizing the modernity of these narratives, I am of course not ignoring that modernism in literature and the arts was well under way beyond the scene of war, too. However, it seems that here as in other respects the war functioned as a catalyst accelerating developments already existing before 1914 (cf. for instance Rabaté) - notably in the case of writers like Aldington or Köppen, who saw themselves as part of a literary avant-garde anyway. The exact nature of the relationship between the Great War and modernity has remained contested. There is consent, however, that the war embodied, in the words of Dan Todman, "a host of tensions inherent in the modern world - between technology and humanity, between state and individual, and between tradition and progress" (436). These tensions are manifested in literature, and literary (and other cultural) representations at the time and since have shaped paradigmatic views of the war as a force of modernity, illustrating, in the words of Randall Stevenson, "the extent to which later decades continued to live, and write, in ways the war shaped, remaining troubled by stresses in the modern world it first made inescapably evident" (225).

\section{Conclusion}

The challenges that trench fighting presented to narrative produced in First World War memoirs and novels a dialogic (and sometimes dialectic) interaction between different elements of the realist paradigm. On the one hand, there were those that still functioned as authentification devices, like specificity, the emphasis on first-hand experience and a 'plain style,' on the other hand there were those that tended to be undermined by the sensory experience of trench warfare, first and foremost among them the realist chronotope. Ultimately, the disintegration of the latter in many war narratives may be said to have produced a hyper-realism which made narrative fragmentation appear as the adequate form for narrativizing the disruptive experience of war. Byron Good has argued that normally "[n]arrative succeeds" in deflecting the full impact of crisis "by 'subjunctivising' reality, by exploring the indeterminacy of reality" (153). There is some evidence in the writings of World War I combatants that this mechanism seems to have failed in the case of the war experience. As the narrative means of structuring the contiguity of experience, and of thus relegating experience to a 'past reality' that could be grasped became dysfunctional, the war was enshrouded in myth, and the front-line assumed the status of a hyper-reality that made the relevance of all other experience dwindle. As Siegfried Sassoon's fictional alter ego, George Sherston, observes from an English war hospital, "[r]eality was on the other side of the Channel, surely" (525). Rendering the "reliving' of experience through the 
quasi-dramatic or filmic re-presentation of events, the war narratives here dealt with indicate that experience cannot be relegated to the past, as the narrator's capacity for giving structure and meaning to that experience has been defeated, as it were, by the chaotic nature and overwhelming scale of events. The texts I have discussed thus reflect the struggle for a new aesthetics adequate to a 'mother of all battles' (in the popular phrase) rather than a 'father of all things,' indicating a turning from 'war art' to a war against (the wrong) art and the traditional aesthetics underlying it.

\section{Notes}

1 For W. B. Yeats (xxxiv), "not a theme for poetry" (original emphasis), and thus the reason to exclude Wilfred Owen from his Oxford Book of Modern Verse.

2 This restriction of vision, incidentally, greatly added to the fascination with the fighter pilots, besides their anachronistic aura of chivalry and single-handed combat: theirs was the panoramic vision which the infantry in particular lacked (cf. Löschnigg 164-202).

3 It is significant, in this connection, that Blunden's book contains frequent references to painting, as for instance in the description of battalion headquarters as "a group of huts Rembrandtesque enough in their rustic structure" (50).

4 In the preface to the second edition of Undertones, he accordingly explains retaining the poems included in the first edition: "if they are of no other quality, they supply details and happenings which would have strengthened the prose had I not already been impelled to express them, and are among such keys as I can provide to the fuller memory" (xliii).

5 However, Blunden's example also reminds one of the linguistic vitality that was also created by the war, especially in soldiers' slang.

6 On Köppen, see Schafnitzel, Murdoch, and Vinzent, the only monograph so far.

7 According to P. E. Mitchell, however, the view that Goodbye is entirely farcical ignores echoes and correspondences between the pre-war sections and the warpassages, as "scenes are being reiterated in progressively darker contexts" (348).

\section{References}

Aldington, Richard. 1929. Death of a Hero. London: Chatto \& Windus. Blunden, Edmund. 2010 [1928]. Undertones of War. London: Penguin.

Bornebusch, Herbert. 1985. Gegen-Erinnerung. Eine formsemantische Analyse des demokratischen Kriegsromans der Weimarer Republik. Frankfurt am Main: Lang.

Brittain, Vera. 1979 [1933]. Testament of Youth. London: Virago. 
Broich, Ulrich. 1994 [1993]. "World War I in Semi-Autobiographical Fiction and in Semi-Fictional Autobiography - Robert Graves and Ludwig Renn." Intimate Enemies: English and German Literary Reactions to the Great War 1914-1918. Ed. Franz Karl Stanzel and Martin Löschnigg. $2^{\text {nd }}$ edn. Heidelberg: Winter. 313-325.

Brückner, Florian. 2015. "Dichtung und Wahrheit: Authentifizierungsstrategien, Verschleierung von Fiktionalität und politisierender Wahrheitsanspruch im Kriegsroman der Weimarer Republik." Dichtung und Wahrheit. Literarische Kriegsverarbeitung vom 17. bis zum 20. Jahrhundert. Ed. Claudia Glunz and Thomas F. Schneider. Special Issue Krieg und Literatur/War and Literature 21: 53-66.

Campbell, James. 1999. "Combat Gnosticism: The Ideology of First World War Poetry Criticism." New Literary History 30. 1: 203-215.

Cobley, Evelyn. 1993. Representing War. Form and Ideology in First World War Narratives. Toronto, Buffalo, London: University of Toronto Press.

Das, Santanu. 2007. "War Poetry and the Realm of the Senses. Owen and Rosenberg." The Oxford Handbook of British and Irish War Poetry. Ed. Tim Kendall. Oxford: Oxford University Press. 73-99.

de Certeau, Michel. 1984. The Practice of Everyday Life. Trans. Steven Rendall. Berkeley and Los Angeles: University of California Press. 1984.

Eksteins, Modris. 1989. Rites of Spring. The Great War and the Birth of the Modern Age. Boston: Houghton Mifflin.

Erll, Astrid. 2003. Gedächtnisromane. Literatur über den Ersten Weltkrieg als Medium englischer und deutscher Erinnerungskulturen in den 1920er Jahren. Trier: Wissenschaftlicher Verlag Trier.

Fludernik, Monika. 1996. Towards a 'Natural' Narratology. London and New York: Routledge.

Ford, Ford Madox. 1999. War Prose. Ed. Max Saunders. Manchester: Carcanet. Ford, Ford Madox. 2012 [1924-1928]. Parade's End. London: Penguin.

Good, Byron. 1994. Medicine, Rationality and Experience: An Anthropological Perspective. Cambridge: Cambridge University Press.

Graves, Robert. 1960 [1929]. Goodbye to All That. London and Harmondsworth: Penguin.

Harrison, Charles Yale. 2007 [1930]. Generals Die in Bed. Toronto: Annick Press. Hüppauf, Bernd. 1990. "Der Erste Weltkrieg und die Destruktion von Zeit." Geschichte als Literatur. Formen und Grenzen der Repräsentation von Vergangenheit. Ed. Hartmut Eggert, Ulrich Profitlich, and Klaus R. Scherpe. Stuttgart: Metzler. 207-225.

Hynes, Samuel. 1990. A War Imagined. The First World War and English Culture. London: The Bodley Head.

Köppen, Edlef. 1979 [1930]. Heeresbericht. Reinbek bei Hamburg: Rowohlt. Jünger, Ernst. 2014 [1920-1967]. In Stahlgewittern. Stuttgart: Klett-Cotta. 
Leed, Eric J. 1979. No Man's Land. Combat and Identity in World War I. Cambridge: Cambridge University Press.

Lejeune, Philippe. 1975. Le pacte autobiographique. Paris: Èditions du Seuil.

Löschnigg, Martin. 1994. Der Erste Weltkrieg in deutscher und englischer Dichtung. Heidelberg: Winter.

Mieszkowski, Jan. 2012. Watching War. Stanford/CA: Stanford University Press.

Mitchell, P. E. 1986. "Robert Graves's Goodbye to All That." Dalhousie Review 66. 3: 341-353.

Müller, Hans Harald. 1986. Der Krieg und die Schriftsteller. Der Kriegsroman der Weimarer Republik. Stuttgart: Metzler.

Murdoch, Brian. 2015. "Documentation and Narrative: Edlef Köppen's Heeresbericht and the Anti-War Novels of the Weimar Republic." German Literature and the First World War: The Anti-War Tradition. London and New York: Routledge 2015. 245-262 [first publ. New German Studies 15 (1988): 23-47]. Orwell, George. 2000 [1940]. "Inside the Whale." George Orwell. Essays. London: Penguin. 101-133.

Rabaté, Jean-Michel. 2007. 1913: The Cradle of Modernism. Malden, Oxford, Carlton: Wiley Blackwell.

Read, Herbert. 1963. The Contrary Experience. London: Faber.

Renn, Ludwig. 1988 [1928, 1930]. Krieg. Nachkrieg. Zwei Romane. Reinbek bei Hamburg: Rowohlt.

Remarque, Erich Maria. 1986 [1929]. Im Westen nichts Neues. Frankfurt am Main, Berlin: Ullstein.

Ricœur, Paul. 1983. Temps et récit. Vol. 1: L'intrigue et le récit historique. Paris: Éditions du Seuil.

Sassoon, Siegfried. 1972. The Complete Memoirs of George Sherston. London: Faber.

Schafnitzel, Roman. 2003. "Die vergessene Collage des Ersten Weltkrieges. Edlef Köppen: Heeresbericht (1930)." Von Richthofen bis Remarque: Deutschsprachige Prosa zum Ersten Weltkrieg. Ed. Thomas F. Schneider and Hans Wagener. Amsterdam and New York: Rodopi. 319-341.

Schwering, Gregor. 2015. "'Kinostil' und Filmriss: Edlef Köppen's Heeresbericht." Zeitschrift für Literaturwissenschaft und Linguistik 179. Special Issue: Die Literatur des Ersten Weltkriegs. Ed. Niels Werber, Felix Hüttemann, and Kevin Ligieri. 9-19.

Seymour-Smith, Martin. 1982. Robert Graves: His Life and Work. New York: Holt, Rinehart.

Stevenson, Randall. 2013. Literature \& the Great War 1914-1918. Oxford: Oxford University Press.

Ströker, Elisabeth. 1977 [1965]. Philosophische Untersuchungen zum Raum. Frankfurt: Klostermann. 
Todman, Dan. 2008. "The First World War in Contemporary British Popular Culture." Untold War. New Perspectives in First World War Studies. Ed. Heather Jones, Jennifer O'Brien, and Christoph Schmidt-Supprian. Leiden and Boston: Brill. 417-441.

Travers, Martin Patrick Anthony. 1982. German Novels on the First World War and Their Ideological Implications, 1918-1933. Stuttgart: H. D. Heinz.

Trotter, David. 2005. "The British Novel and the War." The Cambridge Companion to the Literature of the First World War. Ed. Vincent Sherry. Cambridge: Cambridge University Press. 34-56.

Vinzent, Jutta. 1997. Edlef Köppen - Schriftsteller zwischen den Fronten: ein literaturhistorischer Beitrag zu Expressionismus, neuer Sachlichkeit und innerer Emigration; mit Edition, Werk- und Nachlassverzeichnis. Munich: Iudicium.

Williams, David. 2009. Media, Memory and the First World War. Montreal and Kingston: McGill-Queen's University Press.

Wolff, Leon. 1979. In Flanders Fields. The 1917 Campaign. Harmondsworth: Penguin.

Yeats, William Butler. 1936. "Introduction.” The Oxford Book of Modern Verse, 1892-1935. Ed. W. B. Y. Oxford: Clarendon Press. v-xlii. 

Nancy Sloan Goldberg

(iD) https://orcid.org/0000-0003-3970-7700

Middle Tennessee State University

\title{
From Barbusse to Lemaitre: The Evolution of Experience
}

\begin{abstract}
Direct witness and thoughtful meditation are core values of content and form in the canon of French Great War fiction and were established from the earliest narratives in 1914. Moral authority and ownership of the truth were both the privilege of soldier-writers like Barbusse and Dorgelès, who also sought insightful meaning in their direct experience. Their works remain "in collective memory" and continue to be published, read, and analysed (Grabes). With the passage of time, the gaps in insights and memory of direct witness were filled by fiction in the works of canonical post-memory writers (Rigney). The rediscovery and reappraisal of disparate elements of the war by historians and non-canonical genre writers restored value to some of these objects, such as executions and the reintegration of veterans into society, that had "fall[en] out of frames of attention" (Assmann). Crime fiction novels set during the Great War, by virtue of their non-canonical status as genre fiction, were not restrained by acknowledged and often depreciatory imperatives of form and content. Unencumbered by these canonical constraints, the works of crime fiction writers tell a "counter-history," thus transferring a proscribed and obfuscated subject to the public sphere (Assmann).
\end{abstract}

\section{From Black to White}

In 2013 Pierre Lemaitre's runaway bestseller, Au revoir la-haut (The Great Swindle) won the Prix Goncourt, France's top literary honour. Before this award, Lemaitre enjoyed international celebrity as a writer of crime fiction, or littérature noire, a sub-genre of popular fiction. Crime novels, along with other forms of genre fiction, such as fantasy and romance, are differentiated from littérature blanche, or general fiction, so named for the off-white colour of their book jackets. These designations however have meanings that go beyond the choice of colours for covers and in fact manifest long-standing values held within the sphere of French writing, publishing and book-buying. These viewpoints privilege works that are deemed to proceed from more literary, intellectual and philosophical centres and are selected by certain publishers, like Albin Michel and Gallimard, 
who are identified with these values. The so-called noir books often have black covers, include many categories of popular fiction, and are published by a wide variety of publishers. This white/black distinction is an example of the type of evaluative selection and powerful prestige indicative of an established literary canon (Grabes).

Thus, the sanctification of a crime or noir novel (called polar in French) by the Académie Goncourt, certainly one of the most elite upholders of littérature blanche, was viewed as a promotion for Lemaitre, and the selection of his book as proof of his elevation to the French literary establishment. Writing in Le Monde, book critic Macha Séry heralded the selection of Lemaitre's book as the author's passage from littérature noire to littérature blanche, while Guy Duplat in La Libre Belgique pointedly underscored Lemaitre's outsider position as a noir writer in that year's competition for literary prizes. Lemaitre himself subscribed to the value judgements associated with these designations and boldly and unapologetically explained to the interviewer in Paris Match why he deliberately chose to adopt the characteristics of littérature blanche. Going from black to white would legitimize his reputation with his peers, and most importantly, satisfy a long-held personal desire to be included in the literary elite. The double meaning below conflating cocaine use with the path to "the white" reveals in a self-deprecating way the intensity of his craving:

Quand on est un auteur noir, qu'on écrit des polars, il arrive un moment, dans notre carrière, où on a envie de "sniffer de la blanche": d'écrire des romans, et de devenir enfin, un écrivain. Je ressentais ce besoin. Aussi celui d'être reconnu par mes pairs. Avoir un prix littéraire, c'était pour moi une légitimité, une reconnaissance. On en rêve tous. Moi le premier. (Blanchère)

When one is a "black" author, that is, a writer of crime fiction, at some point in that writer's career, we feel the craving to "inhale the white one [cocaine]": to write novels, and to become finally, a writer. I felt this longing. And the desire to be recognized by my peers. To have a literary prize was for me a legitimacy, a recognition. We all dream of it. Me first. (trans. N.S.G.)

\section{Témoignage and the Canon}

The official distinction of "high" and "popular" literature is one of many possible literary canons identified by Grabes, who also notes the power of these constructions in "the shaping and sustenance of cultural memory" (311). In the case of French Great War literature, the concept of témoignage, or direct witness, was and remains the essential standard for the selection of works authorized for retention. The primacy of testimony was established by soldier-writers from the very first publications of French Great War fiction in 1914 in order to "bring into the public 
sphere some sort of intellectual message drawn from their own experience in the war" (Smith 381). Thus, the degree of authenticity and the extent of a text's realism determined a book's value and worthiness for publication more than any other characteristic or trait. In this sense then, the French writing and publishing establishment became from the earliest days of the conflict an essential part of the "institutions of active memory [which] preserve the past as present [...]" (Assmann 98) and an instrument in the collective remembering that connects the generations (Erll).

Accordingly, the winners of the Prix Goncourt for the years 1914-1918 were restricted to soldier-writers, whose experiences were deemed to be the only valid expressions of faithful authenticity. ${ }^{1}$ These works were experiential, largely episodic and anecdotal narratives saturated with what was considered realistic detail. The emphasis on accuracy in the reception of these publications ignored differences between genres, such as the novel and war narrative, and erected a supposedly irrefutable record of fact. Regardless of category, the soldier in these texts is portrayed as an ordinary man for whom the camaraderie of his squad both eases and advances the completion of his duty. The images of the humble courage and brotherly confidence of the simple French citizens contained in these narratives contrasted sharply and repudiated directly the glaring jingoism of newspaper accounts and best-selling novels written typically by well-known civilian authors. ${ }^{2}$

Moreover, direct witness was privileged to the exclusion of other voices; how could those who had not experienced life at the front, such as women and other civilians, bear witness to what they could not know? Indeed, the word witness (témoin) and its derivatives featured prominently in commentary about these early works. The publication of Jean Norton Cru's extended critical taxonomy of French Great War narratives, Témoins (1929), reiterated and reinforced a viewpoint that had validated and promoted the moral authority and primacy of direct witness from the earliest days of the war.

Despite the passage of time, the predominance of personal experience in the field of French Great War studies has retained its dominant place and pivotal role (Smith). Thus, for Pierre Lemaitre, eager to be granted the mantle of canonical legitimacy, historical precision was a primary value. Indeed, his concern that his novel be considered historically accurate figures prominently in many of the interviews the year of its publication (2013), as well as in the acknowledgements placed at the end of the book. Lemaitre notes that he spent nearly 2000 hours conducting research in libraries and in archives and highlights his debt to well-known Great War historians such as Annette Becker and Stéphane Audoin-Rouzeau. Lemaitre is nonetheless careful to qualify the assertion of accuracy: his book is true (vrai) without being strictly accurate (exact) and that he, as an author, is searching for the truth (la vérité) and not objectivity (l'exactitude). This distinction, repeated so often and so emphatically, is foundational and important for two reasons: it accepts the dominance of témoignage, the long-standing primary value of personal witness in novels published during the war era by soldier-writers such as Henri 
Barbusse and Roland Dorgelès, while simultaneously justifying Lemaitre's own authority and asserting his prerogative to construct, nearly one hundred years after the war, a work of imagination that communicates significant and profound truths about the war (Sokołowska-Paryż and Löschnigg).

\section{Remembrance and Representation}

"When thinking about memory, we must start with forgetting," asserts Aleida Assmann, and what she terms the "perpetual interaction between remembering and forgetting" (97) figures thematically in the canonical novels by Henri Barbusse and Roland Dorgelès. Barbusse and Dorgelès were both soldier-writers, and their respective best-selling and award-winning novels, Le Feu (Under Fire) (1916) and Les Croix de bois (Wooden Crosses) (1919) have remained the best-known works of French fiction on the war. These texts and additionally, Dorgelès' novel of the demobilization, Le Réveil des morts ("The Awakening of the Dead") (1923) tackle major philosophical issues that combatants and veterans faced, and these novels portray the range of emotions in the soldiers' reactions. Perhaps no concern is more compelling or universal than the unease surrounding memory and forgetting. How will the soldiers remember the war if they survive? How will they be remembered if they do not? How long will any of these memories last? Will their involvement in the war have an impact on world events? Will the loss and damage they have come to know most intimately have a lasting value? Throughout the novel, Barbusse's characters struggle to understand how easily and quickly even they are beginning to forget the sights, sounds and odours they thought were indelible. They can accept that civilians might forget the war, and even that it would be normal for them to do so, but for the soldiers themselves? They have seen too much to imagine that it could possibly happen to them:

C'est vrai, c'qui dit, fit un homme sans remuer la tête dans sa cangue. Quand j'sui' été en permission, j'ai vu qu'j'avais oublié déjà bien des choses de ma vie d'avant. $\mathrm{Y}$ a des lettres de moi que j'ai relues comme si c'était un livre que j'ouvrais. Et pourtant, malgré ça, j'ai oublié aussi ma souffrance de la guerre. On est des machines à oublier. Les hommes c'est des choses qui pensent un peu, et qui, surtout, oublient. Voilà ce qu'on est. (239; original emphasis)

"That's right, what he's saying," a man said without moving his head in its collar. "When I was on leave I saw how I'd forgotten lots of things from my life before. There were letters from me that I read like opening a book. And yet, in spite of that, I also forgot what I'd suffered in the war. We are machines for forgetting. Men are things that think a little but, most of all, forget. That's what we are." (trans. Robin Buss) 
Barbusse's allusion to a book as a permanent storehouse of individual memories and experiences underscores the fact that his nameless narrator is consciously writing a book, the book we are now reading. His pledge to write the truth, by putting "les gros mots à leur place, [...] parce que c'est la vérité" (126) ["I'll put the swearwords in, because it's the truth"; trans. Robin Buss] acknowledges, as in the passage above, the distance between the resolve of the person who created a concrete and enduring form of memory, such as a book, and the subsequent attempt to recall that same memory. That the act of remembering is unfortunately subject to various forms of failure, including caprice, randomness and the passage of time, is also featured in Roland Dorgelès' Les Croix de bois, where another soldier narrator is writing another book we are reading. Dorgelès accepts the loss of memories as cruel but entirely natural. For him, the weight of such "souvenirs atroces" (423) is so heavy that they sink to the bottom of the human heart, along with the forgotten dead:

On oubliera. Les voiles de deuil, comme des feuilles mortes, tomberont. L'image du soldat disparu s'effacera lentement dans le cœur consolé de ceux qui l'aimaient tant. Et tous les morts mourront pour la deuxième fois. (424)

We shall forget. The veils of mourning will fall, even as the dead leaves fall. The image of the soldier who is disappeared for ever will slowly fade in the consoled hearts of those he loved so much. And all the dead men will die for the second time. (trans. unknown)

Nonetheless, the book that the narrator is writing seeks to preserve their memory even beyond the lives of everyone who knew them, thus thwarting the "second" death of forgetting. And yet, the narrator's attempt is burdened by his all-toohuman limitations that reveal the collapse of his capacity to accurately remember. Still, although time and trauma have cheated his memory, the transcendent power of art remains intact. The narrator does not yet fully understand that by means of his imagination and concretized by the book he is writing, the men he knew have not vanished but are bound up into an all-embracing whole:

Certains soirs comme celui-ci, quand las d'avoir écrit, je laisse tomber ma tête dans mes mains, je vous sens tous présents, mes camarades. Vous vous êtes tous levés de vos tombes précaires, vous m'entourez et, dans une étrange confusion, je ne distingue plus ceux que j'ai connus là-bas de ceux que j'ai créés pour en faire les humbles héros d'un livre. Ceux-ci ont pris les souffrances des autres, comme pour les soulager, ils ont pris leurs visages et leurs voix, et ils se ressemblent si bien, avec leurs douleurs mêlées, que mes souvenirs s'égarent et que parfois, je cherche dans mon cœur désolé, à reconnaître un camarade disparu, qu'une ombre toute semblable m'a caché. (424)

On evenings such as this when, weary with all I have written, I let my head fall into my two hands, I feel you all beside me, my comrades. You have all risen up 
from out of the insecure tenancy of your graves, and you are round about me, and in a strange confusion, I can no longer distinguish between those whom in the flesh and blood and bone I knew out there, and those I have created to be the humble heroes of a book. These have taken up the sufferings of those, as though to ease and relieve them, they have taken on their face, their voice, and they are so much alike, with their mingled pains and woes that my memories stray, and now and then I strive in my disconsolate heart to recognize a missing comrade whom a shadow in his very semblance has hidden from me. (trans. unknown)

\section{Rediscovery and Restoration: Fusillés and Anciens Combattants}

Issues concerning memory and remembrance took on added importance in the post-memory phase, especially during the 1980's and 1990's (Sokołowska-Paryż and Löschnigg). The dwindling number of Great War veterans, along with the much-publicized trials of ex-Nazis in France, and the increased visibility of Holocaust deniers brought renewed attention and a sense of urgency to the topics of memory and commemoration of both the First and Second World Wars. Historian Leonard Smith notes that the flourishing of studies on memory in France, especially Pierre Nora's important three-volume work, Les Lieux de mémoire (1984-1986), brought about a series of reinterpretations and re-examinations of the role of the soldier, which cast "the soldier as victim turned hero through his victimization" (390). Such reframing and recontextualization of disregarded memory objects resulted in new scholarship on a number of aspects concerning France and the Great War, especially the fusille, the soldier executed for a variety of lawful or extrajudicial reasons as well as the reintegration of veterans (anciens combattants) into the immediate post war French society. Thus, research in the post-memory phase recovered previously marginalised, forgotten and censored topics that were both absent and absented from sites of "active remembering" such as history books, older museum installations and canonical works of fiction (Assmann 103). A new "counter-history" materialized in a variety of non-fiction publications, renovated museum exhibits, and especially in detective novels, a genre of popular fiction.

Some French soldiers were executed from the earliest days of the war for a variety of reasons, including desertion of post, self-mutilation and cowardice in the face of the enemy and most notably for mutiny after the Chemin des Dames offensive in 1917. But there were other times, when soldiers became disoriented in battle and were suspected of desertion, when soldiers were ordered to wear bloodied and dung-filled uniforms, and when officers wanted to displace blame for their own shortcomings on soldiers who would be held accountable. While histories, museums, memoirs and novels mention the subject of the fusillés, the treatment in these books and places is often brief and hurried, as if the writer were swallowing a bitter pill. The metaphor here is not hyperbolic, for as many scholars 
have rightfully indicated, the harsh reality of the executions questions the moral authority of the military and impugns the rationale of a just war (Anderson 223; Offenstadt 69-99). It is not surprising then, that the stories of these men were long excluded from official commemorations as an affront to the soldiers who continued to fight. The vehement polemic that ensued in 1998 following the declaration of French Prime Minister Lionel Jospin that the fusillés should be reintegrated into "notre collective mémoire nationale" ["our national collective memory"] demonstrates the continued solidity of that restricted historiography (Jalons 1998). There were many public officials who argued against any form of recognition of the fusillés as a de facto pardon that would threaten the future defence of France, but there were also those who emphasized instead the cruelty and arbitrariness of military justice (Offenstadt 177-200).

An example of the minimization of the topic of executions is found in chapter 10, "Argoval" in Barbusse's Le Feu. Here a sergeant relates to the narrator and others in his squad the execution of a French soldier that took place that morning. It is important, however, to consider "Argoval" alongside the chapter immediately preceding it, "La grande colère" in which one of the squad angrily recounts his two months of medical leave in the rear. His intense rage is directed at the many shirkers he encounters, and he describes their activities in great detail. In $L e$ $\mathrm{Feu}$, Barbusse often uses antithesis to emphasize his point of view, and in these two chapters he skilfully compares the very different fates of soldiers who were equally guilty of seeking shelter from the fighting. Barbusse briefly evokes the execution and the squad's reaction somewhat matter-of-factly in "Argoval," a sharp contrast to "La grande colère" in which the narrator bitterly parades before the reader a panorama of slackers, both civilian and those in uniform, only to end the chapter with a discussion on heroism, duty, and danger. The injustice Barbusse reveals is less for the executed soldier, who was "un bonhomme comme nous, ni plus, ni moins" (99) ["a bloke like us, no different"; trans. Robin Buss] than for the hypocrisy of those who support the war in word but not in deed: "La guerre signifie danger de mort pour tout le monde, pour tout le monde: personne n'est sacré. Il faut donc y aller tout droit et non pas faire semblant de le faire, avec un uniforme de fantaisie" (97) ["war means deadly peril and sacrifice for everyone, everyone; no one is sacred. So you have to go straight at it, right to the end, and not just pretend, wearing some fancy uniform"; trans. Robin Buss]. While antithesis is a device Barbusse utilizes throughout $\mathrm{Le} \mathrm{Feu}$, it occurs most sharply in the evocation of life at the rear.

Critique and mistrust of civilian behaviour is unambiguous not only in $\mathrm{Le} \mathrm{Feu}$ and Les Croix de bois, both written during the war, but also in two novels of the immediate post war period, equally written by veterans: Le Retour d'Ulysse ("The Return of Ulysse") (1921) by Jean Valmy-Baysse and Le Réveil des morts (1923) by Roland Dorgelès. Both novels recount the hypocrisy and greed of civilians that the returning soldiers encounter from 1919-1920, as well as the inefficiency 
of the French army and government that renders their demobilisation and reintegration into society slow and difficult, if not altogether impossible. The veterans and their daily struggles are at the centre of these novels, and the unfolding of their plotlines likewise depend on the fraudulent schemes and the exploitation of veterans by civilians. Yet public attention in the immediate post war period was focused, not on the veteran, but rather on mourning and commemoration of the dead with more than 36,000 monuments erected in France before 1922 (Prost 1997; Becker). Both Le Retour d'Ulysse and Le Réveil des morts fell out of print and became difficult to identify or find, and the retelling of the story of the soldier's reintegration, disregarded and largely forgotten, became stored as "relicts of passive forgetting" (Assmann 99). In 1977, however, Antoine Prost's monumental and multi-volume work, Les Anciens Combattants et la société française, brought renewed and overtly sanctioned attention to the Great War veteran, along with subsequent historical studies, such as Bruno Cabanes' La Victoire endeuillée (2004), The Men with Broken Faces (2015) by Marjorie Gehrhardt, and even a section in the newly renovated (2016) Mémorial de Verdun, perhaps the most important Great War memory site in France. Not surprisingly, Le Réveil des morts was reprinted in 2010.

\section{Post-Memory Elite and Popular Literature}

The shifting focus among historians in the post-memory period followed a more subtly bifurcated path in literary works of the era. While popular novels readily took up the case of the wrongly executed and the precarity of veterans (see below), narratives with elite credentials continued to combine biography and fiction in the same complementary and interwoven bond as did the canonical works by Barbusse and Dorgelès, with an important difference. In Jean Rouaud's Les Champs d'honneur (Fields of Glory) (1990), Marc Dugain's La Chambre des officiers (The Officers' Ward) (1998) and Olivier Barbarant's Douze lettres d'amour au soldat inconnu ("Twelve Love Letters to the Unknown Soldier") (1993), gaps in memory that result from time, neglect, and even embarrassment, are contemplated and analysed, with imagination and fiction explicit surrogates.

Jean Rouaud's Les Champs d'honneur was a best-seller that won the Prix Goncourt in 1990. Rouaud explores in his work the multi-generational story of his family. Set in a small town in western France, the account is a meditation on memory and the progression and practice of remembering. In considering his own recollections of his family, Rouaud reveals more than the failure to recall that results from the passage of time. Rather than the forgetfulness that grants peace to the "cœur consolé" by time in Dorgelès' book, the memory of the deaths of two great-uncles in Les Champs d'honneur during World War I depresses, disturbs 
and ultimately disrupts forever the lives of those who remain. The slow dissolution, both physically and mentally, of Rouaud's great-aunt Marie anchors the text, but it is the story of the recovery of the body of Emile in 1929 that imposes a destructive, rather than redemptive, memory. Denied help from the government, the remaining brother Pierre travels on his own to retrieve his Emile's body but finds not one but two extensively decomposed bodies impossible to identity. The clandestine nature of the disinterment, and the fact that Pierre has no choice but to take home the two incomplete sets of remains, are memories that bring anguish rather than relief to the family.

The details of the recovery of Emile's body are known thanks to letters to his wife, Aline. This written record late in the book (172-181) is similar to other tangible attempts we have seen to preserve memory from the passage of time, but Rouaud has already sharply undermined its power. The narrator's maternal grandfather, with fewer connections to his in-law family, has rearranged the attic and regrouped the photographs, letters and other objects of both sides of the family, effecting a "redistribution de la mémoire" without chronology or official kinship lines (139). Rouaud recounts this destabilization of the familiar as a rearrangement of memory that erases the authority of remembrance:

De fait, on ne reconnaissait plus le grenier. Si l'on considère que l'ordre n'est qu'une variation algorithmique subjective du désordre, alors on peut dire du grenier ordonné selon grand-père que c'était la même chose qu'avant mais dans le désordre, c'està-dire qu'au chaos il avait substitué un autre chaos, avec cette différence pour nous que celui-là ne nous était pas familier. (138)

The place was hardly recognizable. On the supposition that order is only a subjective variation on disorder, it can be said that the attic as rearranged by Grandfather was the same as before, but that for our chaos he had substituted another, the only difference being that the new one was unfamiliar. (trans. Ralph Manheim)

Such restructuring of memory leaves the details intact and concrete, yet at the same time adrift, separate, and without the foundational capacity to grant meaning or redemption to the survivors. In Rouaud's novel, reticence and confusion produce a breach between memory and perception that remains hollow and his characters disheartened. In Marc Dugain's La Chambre des officiers (1998), however, imagination fills the void in an incomplete set of memories to create an improbable tale of redemption and even happiness. The book is written as the first-person narrative of Adrien Fournier, who suffers extensive facial wounds during a reconnaissance mission in the first few days of the war, and who remains hospitalized for the rest of the war. The book has the form of a diary or memoir and yet we know from interviews with the author that he is in fact Fournier's grandson, and that he wrote the novel at his grandmother's request (Dugain 2013). The story depicts in detail the severity of Adrien's disfigurement, the care given 
by doctors and nurses, his numerous and painful reconstructive surgeries, and those of several other officers in the hospital ward. It is fairly straightforward with little character development and is similar to innumerable war narratives that string together events and anecdotes without analysis. Yet what gives this story interest are precisely those elements that are completely fictional: the conversations and interchanges between characters and the progression of Adrien's inner thoughts. These completely imaginary dialogues make Adrien's story genuine and approachable. They reveal his despair but also a sense of humour that mitigates his tragic circumstances.

While it is clear that Marc Dugain created a vision of his grandfather that would please his grandmother and provide a role model for his children, he also humanized, rehabilitated and made visible these gueules cassées, the men and women with "broken faces." Adrien explains the sad nature of the invisibility that he and others like him endured: "Je vous voyais de trois quarts, vous m'avez vu sans me voir. Les gens défigurés ont ceci de particulier, qu'on les remarque, qu'on ne voit qu'eux, et que, dans le même temps, on ne les voit pas" (151) ["I saw you at a three-quarter angle, you saw me without seeing me. Disfigured people have this peculiarity, that we notice them, that we see only them, and that, at the same time, we do not see them"; trans. N.S.G.]. In giving voice, form and substance to his grandfather and his fellow patients, Dugain countered the absence of memories with fiction. He depicted them as people fully in life, who love and are loved despite their suffering, and this inspirational model resonated with a public who seemed to perceive them for the first time. ${ }^{3}$ The triumph of Dugain's imagination over the absence of memory reiterates Pierre Lemaitre's affirmation of the primacy of the vrai over the exact.

In Douze lettres d'amour au soldat inconnu (1993) Olivier Barbarant creates an identity for the Unknown Soldier buried under the Arc de Triomphe in Paris. Unlike Rouaud and Dugain, Barbarant has no family connection with the war to orient his memory or link him to a shared national past. The commemorative parades he witnessed as a teenager left him with a "sourde hostilite" for the hypocrisy and deceit he recognized in official remembrance: "il y avait surtout dans ce troupeau de petits vieux délabrés un mensonge, puisqu'ils acceptaient, leur chair tenue dans la raideur des costumes, l'œil vitreux, l'hommage rendu à ce qui ne fut que leur mise à mort" (35) ["There was especially in this herd of the elderly and decrepit a particular lie, because they accepted, with their flesh held in by the stiffness of their uniforms and their watery eyes, the homage paid to what was simply their own slaughter"; trans. N.S.G.] Barbarant's expressed goal is to reverse the duplicity of memory manufactured by the war's survivors and to "détroner le dieu de la guerre que le siècle a inventé" (31) ["to destroy the god of war that the century invented"; trans. N.S.G.]. He seeks to counter the idealized and deified image of the Unknown Soldier with an invention of his own. Inspired by the washed-out photograph of a soldier he remembers from his 
high school history book and a few chance postcards, Barbarant creates a onedirectional correspondence that visualises the poilu's last days and moments, and he even imagines the possibility that the soldier discretely congratulated Pierre Brizon, one of three socialist deputies in the French assembly who refused to vote for war credits in 1916.

In Douze lettres d'amour au soldat inconnu, Barbarant creates an entirely fictional narrative that effectively undermines the long-standing authority of historical memory and recognizable experience. His imaginary correspondence with the dead soldier has no link with the canonical experiential accounts in the tradition of Barbusse and Dorgelès that commonly represent First World War fiction. Neither does Barbarant explore in his work the deficiencies of the process of remembering as do Rouaud and Dugain. Rather his text interrogates and ultimately rejects the dominant and normative understanding of experience, to consider it rather as a vehicle of official indoctrination on the meaning of the war. For Barbarant, the ceremonies on November 11 are stomach-churning theatre, a yearly resurrection that "dément la misère et anesthésie le scandale de ce corps de vingt ans mis à mort" (31) ["denies the misery and anesthetises the scandal of the butchery to this twenty-year-old body"; trans. N.S.G.]. His text creates an imaginary world freed from the constraints of the politics of remembrance, in which only fiction has the capacity to truly "voir le malheur en face" (31) ["face up to the reality of catastrophe"; trans. N.S.G.].

Rather than analyse and subsequently embrace or discard canonical tropes of Great War remembrance, detective and other genre writers preferred instead to examine the recently recovered topics of the fusillés and the anciens combattants in the format they knew best. In commenting on his deliberate choice of writing popular fiction, the well-known crime novelist Didier Daeninckx observed that littérature noire alone provides the unlimited creative freedom forbidden by the "crushing weight" of literary tradition ("Écrire la guerre : rencontre avec Didier Daeninckx, Jean Rouaud et Gilles Heuré" 2015). While hyperbolic, certainly, Daeninckx's assertion confirms Aleida Assmann's classification of remembering and forgetting. We recognize in the recent prominence of the fusillés and the anciens combattants a transfer from active forgetting to active remembering, that is, from taboo and censored memories to the working memory associated with the canon and the museum (99). Moreover, Ann Rigney notes that fiction can function as "oppositional memory" that "undermines hegemonic views of the past" (348). Writers of popular fiction, unlike Olivier Barbarant, are free from the expectations and exigencies required by the elite littérature blanche and have no impediments to articulate the marginalised accounts of the fusillés and the anciens combattants:

In the case of traumatic events, moreover, the freedoms offered by fictional genres and literary modes of expression may simply provide the only forum available for recalling certain experiences that are difficult to bring into the realm of public 
remembrance or that are simply too difficult to articulate in any other way. (348; original emphasis)

The majority of the numerous crime novels set in the period of the Grande Guerre since the 1980's portrays the corruption and greed of French officers and civilians that result in extrajudicial executions, exploitation of soldiers and veterans, and extreme violence. Among the best-known are Le Boucher des Hurlus ("The Hurlus Butcher") (1982) by Jean Amila, film adaptation Sortez des rangs (1995), which inspired Daeninckx's own Le Der des ders ("The Last of the Last") (1984), republished with Jacques Tardi in graphic novel format in 1997; Sébastien Japrisot's Un long dimanche de fiançailles (A Very Long Engagement) (1991) also adapted for the screen in 2004; the six-part series, Célestin Louise, flic et soldat dans la guerre de 14-18 ("Celestin Louise, cop and soldier in the First World War") by Thierry Bourcy (2005-2014); Les Âmes grises (Grey Souls) (2003) by Philippe Claudel, film adaptation in 2005; Patrick Pécherot's Tranchecaille ("Trench Chick") (2008), L'Inconnue de la tranchée "Unknown Woman of the Trench" by Hélène Almalric (2013), and Pierre Lemaitre's Au revoir là-haut, winner of the Prix Goncourt for 2013, graphic novel version in 2015 and film adaptation in 2017.

The long tradition of the polar, or detective and police fiction, is steeped in allegories of good and evil, and the development of the story generally leads the principal investigator, as well as the reader, through a process of vindication and absolution to a satisfying restitution of order (Ekstam, 2015). Do Daeninckx and the other authors construct an allegorical landscape where good triumphs over evil and order is restored? In Le Der des ders (1984), Daeninckx creates a complicated plot that indicts several crimes and social injustices committed before, during and even after the war. The sweeping scope allows him to demonstrate the connections he sees between social problems based on real-life situations, like the efforts of Parisian anarchists to alleviate the pre and post war exploitation of apartment renters, and the widespread trafficking and extortion that proliferated after the war. The mutiny of Russian troops at La Courtine following the Russian Revolution in 1917, as well as the better-known mutinies of French troops that same year, are not merely background elements but are intrinsic to the plot development. From the summary execution that conceals an officer's act of cowardice to the image of wheel-chair bound amputees at a wedding, Daeninckx interweaves historical events and imagination to create a bleak vision of society. That the story ends with the violent death of his detective René Griffon and the triumph of the culpable officer, rather than with justice re-established and order restored, shows the profound and lasting disruption of society produced by the war.

As in Daeninckx's book, the disconnect between the soldiers at the front and civilians in the rear is a plot point common to the crime novels. These works underscore the hypocrisy of civilians who evade military service while proclaiming 
loudly their patriotic fervour. The non-combatants are guilty of fleecing the poilus when they are alive and profiting off of monument sales when they are dead. In Philippe Claudel's Les Ames grises (2003) a local district attorney commits a murder in a small town near the front but uses his position and legal connections to frame two hapless deserters caught by chance. One of the deserters commits suicide to escape the ordeal, but the other valiantly protests his innocence. The judge and the army prosecutor, overfed and self-righteous, tie the soldier nude to a tree in freezing temperatures, douse him with water and beat and kick him in an effort to exact a confession, thus supposedly solving the murder.

The extra layer of cruelty in Les Ames grises robs the soldier of his humanity and vacates his punishment of any notion of judicial validity. As violent and cruel as execution might be, it is nonetheless supposedly required to adhere to certain boundaries and norms of military justice. These customs and rules, even when applied to the death penalty, tend to give the practice a certain legitimacy and acceptability. However, the gruesome brutality depicted in the executions in Un long dimanche de fiançailles (1991), far surpasses that shown in Les Ames grises. At the beginning of his crime novel, Sébastien Japrisot recounts the fate of five soldiers condemned for self-mutilation. Not all of the five are guilty, but the arbitrary reason for their sentences only adds to the barbarity of the method selected for their punishment. After marching for days in the mud and brutal cold of January, 1917, they are bound and placed in No-Man's-Land, where bright lights and loud noises are sure to bring German shells and machine-gun fire that will kill them. The other soldiers are repulsed by this excess of brutality, especially since one of the men is not yet twenty years old and has obviously had a mental break down. Nonetheless they are forced to carry out this extrajudicial execution that leaves no proof or paper trail (Japrisot).

Patrick Pécherot's Tranchecaille (2008) begins after the execution of Antoine Jonas has already occurred. The principal narrator, charged with defending Jonas believes that "la justice militaire, parce qu'elle est justice, était l'honneur de l'armée" (12) ["military justice, because it is the law, was the honor of the army"; trans. N.S.G.]. The multiple points of view, told through an alternating series of letters, reports, and eye witness accounts slowly reveal that the case is more complicated than the murder of an officer by an enlisted man. This fragmented style of narration reproduces Duparc's process of discovery and makes him and the reader aware of historically-based issues relevant to the murder: the hostility and hypocrisy of civilians, the problematical position of the war godmothers, and especially, the class prejudices that separate officers and enlisted men. Contemporary readers would have recognized in the novel a reference to Lucien Bersot, the soldier executed for refusing to put on a blood-stained uniform, whose story had been adapted to television. ${ }^{4}$ Duparc races against time to save Jonas, a man whose inability or unwillingness to help himself only adds to the wide-spread assumption of his guilt. That Duparc remains committed to upholding justice 
during the war is deemed worthless by his commander. The book ends confirming this point of view. Good does not triumph over evil and there is no absolution. The day after the execution, Duparc and others are sent into battle. Whatever satisfaction the reader might have shared with Duparc for solving the murder evaporates in the last scene with his death.

\section{6. "Le premier crime, c'est la guerre"}

Perhaps the only way to restore order is not to reinstate it, but to subvert it. Two crime novels, each a kind of chronological bookend, propose revenge as an alternative in the allegory of right and wrong. If we accept Pierre Lemaitre's contention that "le premier crime, c'est la guerre" (Lemaitre, "Le Prix Goncourt" 2013) ["the original crime is the war"; trans. N.S.G.], then the locus of culpability resides not with the characters in the novels regardless of their actions, but with those who orchestrated the war. Vengeance for this original crime is served in these classic "caper" novels, not as the proverbial cold dish, but with humour and the sense that justice in some form will prevail. True to the time-honoured structure of the caper novel, both Le Boucher des Hurlus, (1982) by Jean Amila and $A u$ revoir là-haut (2013) by Pierre Lemaitre, recount the intricate planning and suspenseful accomplishment of the act(s) of retaliation from the point of view of the perpetrators. The reader experiences along with the characters the abusive circumstances that led to the need for revenge and the gradual unfolding of the plot to retaliate. Balance and equilibrium are restored when the authors of the original crime become in turn the victims of those they victimized.

In Le Boucher des Hurlus, a young boy, Michou, and his mother are living in poverty in post war Paris and are ostracized by their working-class neighbours because of the father's execution for mutiny. Amila portrays the violent confrontation between the widow and her neighbours as a clash of competing memories, for the widow's defence of her executed husband threatens for them the validity of the sacrifice of their soldiers who died. With no pity for the widow or her child, these civilians conspire with government institutions to further isolate them and reduce their economic circumstances. Sent to an orphanage, Michou encounters other children whose fathers were also executed under the command of general Des Gringues, and Amila structures the rest of the story as a paradigmatic odyssey, a quest for justice for these men. This framework provides ample opportunity for Amila, much as other authors would later, to analyse the war's effect on the social reality of Paris and the devastated regions of the Red Zone, the worsening poverty of the post war period and the aggravation of conflicts among social classes. Amila casts Michou as the "archangel de Justice" who succeeds in killing his mother's main tormentor and burning down the entire building where they all lived. Such a violent punishment seems disproportionate to her crime and certainly 
dishonours Michou's mission and role as a justicier. Amila restores the wholesome virtue of Michou's quest for justice through a humorous deus-ex-machina resolution: the hated general the boys targeted dies from complications from the Spanish flu, although they believe that he succumbed due to the hatpin they thrust ceremoniously in his picture.

The smug patriotism of Amila's Parisians "tout gonflés d'avoir gagné la guerre" (181) ["all puffed up at having won the war"; trans. N.S.G.] and the general self-absorption of most civilians are also motivating forces in Pierre Lemaitre's Au revoir là-haut (2013). The summary execution ${ }^{5}$ that provides the book's title and prologue, as well as the first chapter, recount "le premier crime" that sets into motion the complicated double swindle that unfolds across this novel. Lemaitre examines the many difficulties in the lives of returning soldiers by interweaving their stories with schemes designed to defraud and exploit the government and the public at large. The research of post-memory historians, especially Béatrix Pau-Heyriès, as well as the aforementioned novels of the demobilisation by Jean Valmy-Baysse and Roland Dorgelès uncover important and specific facts concerning the period 1919-1920, especially during the French government's establishment of national cemeteries. Motivated to participate in a parallel act of communal mourning, individual communities sought to construct monuments and memorials to the fallen. However, the lack of specific guidelines created a situation ripe with possibilities for fraud and deceit as unscrupulous profiteers moved in to capitalize on the public's need and desire to memorialize the dead soldiers. Lemaitre's storyline recaptures these forgotten and misplaced material vestiges of the past: his characters, two former combatants, Édouard Péricourt, a gueule cassée who is thought to be dead but is living in the shadows of society with Albert Maillard, use their skills to sketch and sell models of war memorials they know will never be built. A third veteran, a former officer, Henri d'AulnayPradelle, who was largely responsible for the intense suffering of the two schemers in the last few days of the war, devises his own plan to profit from the reburial of soldiers and the sale of coffins to the new cemeteries.

In Édouard, Lemaitre created an avenger, similar to Michou in Le Boucher des Hurlus. The evocation of the acute pain, anguish and distress that is the reality of Édouard's day to day life imbues the monuments scheme with righteous vindication. This act of revenge, however, has greater importance in the novel than a simple way to exact payback for a permanently wounded soldier's suffering, for it ridicules and impugns the motivations of the public that accepted and consented to the war. The designs and language of the monuments catalogue echo the hyperbolic patriotic and nationalistic slogans of heroism, sacrifice and glory prevalent during the war and convince families and public authorities to commission these monuments in honour of their lost sons and other relatives. That such exaggerated drawings and slogans could still attract a positive response from the public in 1920 underscores the novel's judgement that everyone is 
accountable for the war. The extent of the swindle is the fitting punishment of an entire country that supported the war and is now obsessed with commemorating the dead, a fixation, the author wryly notes, that is equal to their revulsion for survivors like Édouard and Albert. Lemaitre concludes that the purpose of the memorials is not to represent an individual feeling but to express a collective sentiment, to respond to the greater public's need and desire to remember the fallen soldiers as national heroes, in an effort to put their personal experiences of the war solidly in the past. Significantly, Lemaitre connects the monuments hoax to the consecration of the tomb of the Unknown Soldier on November 11, 1920, a vast national communion that effectively subsumed all of the deceased into a single symbolic death. ${ }^{6}$ The fury to commemorate the fallen in $\mathrm{Au}$ revoir là-haut is less as an act of individual mourning than a pretext to release any lingering feeling of responsibility or guilt. The moment the swindle is revealed publicly brings immense joy and peace to Édouard, who understands his revenge as a settling of moral debts and a colossal act of heroism.

\section{Conclusion}

This essay began with a query into Lemaitre's polemical defence of his right to tell the "truth" about the Great War in his novel, despite the fact that he had no direct experience of that war. His distinction between truth and accuracy seems overwrought and defensive, as if he were protecting himself from a threat, verbal or written. To problematize his assertion leads to an investigation of the canonical pressures in both form and content on French fiction writers of the Great War: requirements to rehearse the direct witness and meditative reflection that emanate from the battlefield experience. Examination of fiction published in the post-memory period exposes differences beyond those of format. Novels classified as litterature blanche, the venue of cultural prestige and power, sustain the traditional themes and conventions that are part of what Aleida Assmann named the "reductive and restrictive drive" of the "active working memory of society" (106). The recovery by historians in the post-memory period of the disregarded and/or censored memory traces concerning the fusillés and the veterans become, in Assmann's terms, part of "a second-order memory that preserves what has been forgotten," and she notes the important role of fiction in filling the gaps in historical records (106). Historian Bruno Cabanes concurs, admitting that the paucity of conventional documents limits comprehension of the veteran's social reintegration, while conceding that literary works may be the only way to access the complex and often contradictory emotions of the returning soldier $(20,248)$. In French novels of the Great War, it is in the domain of la litterature noire, a genre of popular fiction as historically marginalised as its suppressed subject matter, that the memory of forgotten objects is restored. The noir novels 
go beyond a surface reinterpretation of the soldier as victim to show the process of their victimization: the excesses of military justice, the abuse and exploitation of veterans, the unequal sacrifice of officers and enlisted men, and the pervasive self-interest that beleaguered commemoration of the dead.

\section{Notes}

1 Adrien Bertrand, L'Appel du sol, 1914; René Benjamin, Gaspard, 1915; Henri Barbusse, Le Feu, 1916; Henry Malherbe, La Flamme au poing, 1917; Georges Duhamel, Civilisation, 1918.

2 For example, Marcelle Tinayre's La Veillée des armes, 1915, Paul Géraldy's La Guerre, Madame, 1916 and famed Spanish novelist Vicente Blasco Ibáñez's Los cuatro jinetes del Apocalipsis 1916, written at the request of French president Raymond Poincaré.

3 La Chambre des officiers was an award-winning novel and popular film.

4 Lucien Bersot was executed for disobedience in 1914. His story was the subject of Le Pantalon, a book by Alain Scoff (1982) and a television film of the same name in 1997.

5 The words are from the last letter written by Jean Blanchard, one of the socalled Vingré martyrs. The men were falsely accused of desertion, executed December 4, 1914 and rehabilitated in 1921.

6 Bernard Tavernier's 1989 film, La Vie et rien d'autre also critiques the establishment of the tomb of the Unknown Soldier as a means to shift attention from the massive numbers of dead to one, symbolic death.

\section{References}

Amila, Jean. 1982. Le Boucher des Hurlus. Paris: Gallimard.

Anderson, Jean. 2014. "What Price Justice? French Crime Fiction and the Great War." The Great War in Post-Memory Literature and Film. Ed. Martin Löschnigg and Marzena Sokołowska-Paryż. Berlin: De Gruyter. 215-229. Assmann, Aleida. 2008. "Canon and Archive." A Companion to Cultural Memory Studies. Ed. Astrid Erll, Ansgar Nünning, and Sara Young. Berlin: De Gruyter. Berlin: De Gruyter. 97-107.

Barbarant, Olivier. 1993. Douze lettres d'amour au soldat inconnu. Mayenne: Champ Vallon.

Barbusse, Henri. 1994 [1916]. Le Feu: journal d'une escouade. Paris: Omnibus. Trans. Robin Buss, 2003.

Becker, Annette. 1988. Les Monuments aux morts: patrimoine et mémoires de la grande guerre. Paris: Editions Errance. 
Blanchère, Emilie. 2013. "Rencontre avec le Goncourt 2013.” Paris Match. http:// www.parismatch.com/Culture/Livres/Pierre-Lemaitre-rencontre-avec-le-Goncourt- 2013-535422

Cabanes, Bruno. 2004. La Victoire endeuillée. Paris: Seuil.

Claudel, Philippe. 2003. Les Ames grises. Paris: Stock.

Daeninckx, Didier. 1984. Le Der des ders. Paris: Gallimard.

Dorgelès, Roland. 1919. Les Croix de bois. Paris: Albin Michel.

Dugain, Marc. 1998. La Chambre des officiers. Paris: Éditions Jean-Claude Lattès.

—. 2013. Centenaire de la lère Guerre mondiale. N. Frochot, Interviewer. YouTube. https://www.youtube.com/watch?v=VQrMG6IKcBI

Duplat, Guy. 2013. "Pierre Lemaitre remporte le Goncourt, Yann Moix le Renaudot." La Libre Belgique. http:/www.lalibre.be/culture/livres-bd/pierre-lemaitreremporte-le-goncourt- yann-moix-le-renaudot-52778535357046af56a097f2

Écrire la guerre: rencontre avec Didier Daeninckx, Jean Rouaud et Gilles Heuré. Rencontre littéraire. 2015. Lille, France: Université de Lille. https://vimeo. com/122111116

Ekstam, Jane. Mattison. 2015. "Modern Detective Novels and World War One: A Symbiotic Relationship." English Studies 96. 7: 799-817.

Grabes, Herbert. 2008. "Cultural Memory and the Literary Canon." A Companion to Cultural Memory Studies. Ed. Astrid Erll, Ansgar Nünning, and Sara Young. Berlin: De Gruyter. Berlin: De Gruyter. 311-313.

Jalons. Institut National de l'Audiovisuel (INA). 1998. Discours de Lionel Jospin à Craonne. http://fresques.ina.fr/jalons/fiche-media/InaEdu05903/discoursde-lionel- jospin-a-craonne.html

Japrisot, Sébastien. 1991. Un long dimanche de fiançailles. Paris: Éditions Denoël. Lemaitre, Pierre. 2013. Au revoir là-haut. Paris: Albin Michel.

—. 2013. Le Prix Goncourt a été attribué lundi 4 novembre à Pierre Lemaitre, pour son roman Au revoir la-haut. France Inter 5 novembre 2013. Invité de 7h50. L. Salamé, Interviewer. France Inter. https://www.franceinter.fr/emissions/ invite-de-7h50/invite-de-7h50-05-novembre-2013

Offenstadt, Nicolas. 1999. Les Fusillés de la Grande Guerre et la mémoire collective, 1914-1999. Paris: Éditions Odile Jacob.

Pécherot, Patrick. 2008. Tranchecaille. Paris: Gallimard.

Prost, Antoine. 1997. "Monuments to the Dead." Realms of Memory, The Construction of the French Past. Vol. II: Traditions. Ed. Lawrence D. Kritzman. Trans. Arthur Goldhammer. New York: Columbia University Press. 307-330.

Rigney, Ann. 2008. "The Dynamics of Remembrance: Texts Between Monumentality and Morphing." A Companion to Cultural Memory Studies. Ed. Astrid Erll, Ansgar Nünning, and Sara Young. Berlin: De Gruyter. 345-353.

Rouaud, Jean. 1990. Les Champs d'honneur. Paris: Éditions de Minuit. Trans. Ralph Manheim, 1992. 
Sery, Macha. 2013. "Le Prix Goncourt attribué à Pierre Lemaitre.” Le Monde. http:// www.lemonde.fr/livres/article/2013/11/04/le-prix-goncourt-2013-decerne-apierre- lemaitre_3507468_3260.html.

Smith, Leonard. V. 2016. "France, the Great War, and the 'Return to Experience."” The Journal of Modern History 88: 380-415.

Sokołowska, Marzena. and Martin Löschnigg. 2014. "Introduction: "Have you forgotten yet ?..." The Great War in Post-Memory Literature and Film. Ed. Martin Löschnigg and Marzena Sokołowska-Paryż. Berlin: De Gruyter. 1-13. 

Anna Branach-Kallas

(iD) https://orcid.org/0000-0001-5754-1906

Nicolaus Copernicus University, Toruń

\title{
World Travellers: Colonial Loyalties, Border Crossing and Cosmopolitanism in Recent Postcolonial First World War Novels
}

\begin{abstract}
This article offers a comparative analysis of the representation of travelling men and women in The Sojourn (2003) by Canadian writer Alan Cumyn, The Daughters of Mars (2012) by Australian novelist Thomas Kenneally and Blue Ravens: Historical Novel (2014) by North American indigenous author Gerald Vizenor. These three novels explore the cliché of colonial loyalties, illustrating the diverse motivations that led individuals from North America and Australia to volunteer for the war. Cumyn, Kenneally and Vizenor undermine the stereotypical location of the colonial traveller in an uncultured space; in their fiction the war provides a pretext to expose imperial ideologies, to redefine collective identities, as well as to rethink the relationship between the local and the cosmopolitan. As a result, the First World War is reconfigured in terms of border crossing, contact and/or transcultural exchange, which result in radical shifts in consciousness, a critique of imperialism, as well as aspirations for cultural/political autonomy.
\end{abstract}

The Great War was the first conflict in which peoples from all over the globe fought and worked together, "rarely in equality other than equality of suffering" (Olusoga 15). The British promoted an image of the war as a common imperial effort, emphasising at the same time that it was a privilege for colonial men to fight for the same goal with British soldiers. While many white men in the colonies and dominions eagerly volunteered for service, motivated by the desire to defend European culture, coloured men saw the war as an opportunity to prove themselves alongside white troops or were simply coerced to fight in the imperial armies. Notwithstanding their true motivation, the war involved an unprecedented scale of international movements, with nearly 70 million men in uniform during the conflict (Winter 46). 1.3 million were recruited in the dominions - Canada, Newfoundland, Australia, New Zealand and South Africa. Later in the war, the United States contributed approximately two million men, including ten thousand Native Americans. In total, over four million non-white men served in the European 
and American armies during the 1914-1918 conflict (Das 4). The intense traveling of men of various nations, ethnicities and races all over the globe resulted in unexpected, deeply transformative cross-cultural encounters. For non-European soldiers, the war was an opportunity to discover the culture of the metropolis and to revise their ideals about the colonial centre. Paradoxically, although fought in defence of European empires, the war was also a powerful catalyst of nationalist, anti-colonial sentiments.

The purpose of this article is to analyse the representation of travelling men and women in recent American, Canadian and Australian First World War fiction. I use an imagological approach to demonstrate how, inspired by historical sources, three contemporary writers explore the cliché of colonial loyalties and illustrate the diverse motivations that led individuals from North America and Australia to volunteer for the war. Interestingly, The Sojourn (2003) by Canadian writer Alan Cumyn, The Daughters of Mars (2012) by Australian novelist Thomas Kenneally and Blue Ravens: Historical Novel (2014) by North American indigenous author Gerald Vizenor all undermine the stereotypical location of the colonial traveller in a colonized, uncultured space. The novels under consideration question the stereotype of the First World War colonial as a simpleton, eager to give his life as a blood tax to the metropole. Consequently, in this fiction the war provides a pretext to expose imperial ideologies, to redefine collective identities, and to reconfigure the relationships between travellers and "travelees," between the local and the global, and between the national and the cosmopolitan.

Rooted in the philosophy of the Enlightenment, which defined cosmopolitanism in terms of travels and universalism, at the turn of the twenty first century the term acquired several new meanings. As Rebecca L. Walkowitz contends, our contemporary understanding of cosmopolitanism refers to three different intellectual traditions: a tradition of detachment from the polis, or the local, in favour of a transnational identity; a philosophy of shifting attachments to several communities, beyond one nation; a more popular definition based on consumerism and urban mobility (9). Amanda Anderson's definition of cosmopolitanism as "a term that can describe various aesthetics, ethics, and intellectual programs" (92) has also proved illuminating for the analysis that follows.

\section{Canadian Colonizers: The Sojourn by Alan Cumyn}

The protagonist of The Sojourn by Alan Cumyn, Ramsay Crome, is a Canadian artist, the son of an English immigrant to Canada and a South American mother. At the outbreak of the war, he believes in war propaganda and wants to defend European civilization and the Mother Country against the hordes of barbaric Huns. Fighting to survive at the front, however, he soon loses his illusions about "this blasted, necessary war" (Cumyn 36). The first part of the novel, as noted by Neta 
Gordon (94-95), reproduces the features of the "paradigmatic British war novel," conceptualising front-life in terms of traumatic disenchantment, "an education in disgust" (Trotter 40), or dramatic conflict with irresponsible officers (Fussell 82-86). However, central in The Sojourn is the second part, depicting Ramsay's ten-day leave in London, during which he meets his English family and falls in love with his eldest cousin Margaret. Ramsay's stay in the refined capital of the Empire is constantly disrupted by flashbacks to the sombre realities of the frontline. Cumyn explores in-depth the contrast between the experience of traumatized soldiers and the comfortable existence of civilians, whose ideas about front life are naïve and superficial. They complain about the Zeppelins, inflation and coal rationing, a perspective which Ramsay finds ridiculous and unfair. The sense of estrangement the soldier protagonist experiences at the home front, according to Paul Fussell (86), is characteristic of the Great War literary imagination.

More important in the novel, however, is the tension caused by the encounter between the Old and the New Worlds. ${ }^{1}$ Such family reunions with relatives they had never met were common among the soldiers of the Canadian Expeditionary Force, many of whom travelled to the land of their ancestors for the first time in their lives during the war (Vance 2012, 79). Although Ramsay, like many of the Canadian-born volunteers, "was raised and educated in an environment that valued the British connection," he comes to Britain as a tourist and his leave in London is an entirely new experience (Vance 2012, 79). Suffering from a mild form of culture shock, Ramsay is particularly sensitive to the British class structure, which forced his father, as a younger son unentitled to inheritance, to emigrate to Canada. Raised in an eclectic, multicultural environment, he imagines the English Cromes as "half-grown mutants," weakened by generations of inbreeding (Cumyn 161). Unexpectedly, his female cousins prove charming and his upper-class English family most kind. His appearance causes epistemological, emotional and psychological disarray among his relatives. At the same time, the male protagonist also experiences conflicting emotions, when he is abruptly displaced from the war zone into the world of civilians; from a universe of dying men into the world of attractive women; from Canada into a simultaneously familiar and unfamiliar, deeply stratified, Old World culture. Consequently, Ramsay's trip to London involves several - literal and metaphorical - border crossings.

In Cumyn's novel, loyalty to the Empire operates in conjunction with such notions as class, ethnicity and "race." For Ramsay's uncle Manfred, it is a shock to discover that his nephew has volunteered as a private, and not as a junior officer. He is unable to understand the young man's doubts about his ability to take a leadership role, to which, in the Englishman's opinion, people of his class are predisposed. Consequently, the Cromes assume that Canada is "a more classless sort of place," and the Canadian army more egalitarian than the British one (Cumyn 106). However, their conviction that the English are a superior nation is made clear when Manfred comments on the Easter Rising in Ireland which, 
according to him, results from "a profound cowardice in much of Irish blood" (Cumyn 107). Englishness is defined in the novel as dominance over inferiors at home (the working class), close to home (the Irish) and far from home (the colonials). What is more, admiring the political cartoons of the Dutch painter, Louis Raemaeker, at a London gallery, Ramsay comes to the conclusion that his portrait of crucified Europe tied to a wheel is reminiscent of the particularly cruel Field Punishment Number One, which was practised by the British army, not the German one. Interestingly, the oppressive, "uncivilized" character, attributed in the drawings to the Germans, is thus disturbingly conflated in the soldier's imagination with British military culture. However, it is important to note that Ramsay himself shares some of the dominant views about the inferiority of the German "race" (Cumyn 122). In this way, Cumyn illustrates the "intra-European" racism which, together with skin colour, functioned as the source of "racial" classifications among the multi-ethnic and multi-racial troops of the First World War (see Das 11-12).

The Sojourn also highlights British misconceptions about Canada in general and Canadian soldiers in particular. The figure of Ramsay is contrasted in the novel with that of Henry Boulton, Margaret's fiancé, a delicate middle-class English young man who works at the Ministry of Munitions. In Margaret's view, Henry is a vulnerable and talented individual, whose gifts would be wasted at the front; she seems strangely unaware of Ramsay's artistic talent, perceiving him as a dangerously attractive, "natural" warrior:

"But you've lived in the wilds of Canada," Margaret says. "You haven't grown up breathing the filth of London air. You're strong and fit and you probably already knew how to shoot a rifle before you joined up. Poor Mr. Boulton has been of precarious health since he was a youth. And besides, he has been educated [...]." She stops herself. "Not that you haven't been educated," she says. "Of course you have schools in Canada." (160)

In this passage, Cumyn critiques the stereotypical contrast between England as the centre of culture and intellectual activity and Canada as nature and bodily endurance. Raised at the margins of the Empire, Canadians cannot aspire to share the intellectual sophistication of Englishmen; at the same time, due to the difference in environment, the men from the colonial centre are naturally weaker than their Canadian counterparts. Cumyn also relies here on the image of Canadians, popularised by war propaganda, as a nation of healthy, strong individuals, accustomed to the daily struggle with nature in a demanding climate (Keshen 4). In reality, most Canadian volunteers were industrial workers and clerks who lived in cities (Vance 1997, 161).

Unable to see beyond colonial stereotypes and embarrassed by her erotic desire for him, Margaret feels uneasy about her cousin's manly endurance, fierce independence and bodily appetites. When she encounters Ramsey inebriated, the female protagonist classifies him as a colonial "savage" and admonishes him about 
his uncivilized comportment (Cumyn 237). The young woman's disapproval of her cousin echoes the British perception of Canadians during the First World War: they might be gallant warriors "toughened by the frontier, but they had become uncivilized, uncouth" and needed to be re-civilized by the British (Vance 2012, 57). Ironically, Ramsay is a particularly mature and insightful young man, who, in spite of his traumatic experience, is willing to go back to the front, because he cannot abandon his comrades-in-arms, a conception of duty his English relatives are unable to grasp. Cumyn thus undermines several colonial stereotypes, depicting the Canadian protagonist as a disillusioned individual, misunderstood by his English family, yet also playing havoc with their well-ordered lives. ${ }^{2}$

From the point of view of the English Cromes, Canada's imperial allegiance to Mother Britain is unproblematic - they consider participation in the war a privilege for the inhabitants of the dominions (Cumyn 197). Manfred and his wife cannot understand Ramsay's parents' reactions, his mother's fury and his father's cold restraint about the war, for, in their view, their Canadian relatives should be proud that their sons are willing to fight for England and the Empire. In the English Cromes' view, Ramsay's arrival only confirms that "Young men from around the Empire have answered the call" (Cumyn 160). In reality, the Canadians' motivations were much more complex: while the war "fostered feelings of imperial connectedness," it also "enhanced Canadian nationalism" (Vance 2012, 99). Close relations with the British during the war, as well as the achievements of the Canadian Corps, made Canadians more aware of their distinctiveness and encouraged them to envision a new, invigorated Empire, in which Canada would play a central role (Vance 2012, 99; 110). Their belief in the British liberal ideals was quite separate from their critique of Englishness, which Ramsay shares in The Sojourn. Cumyn's male protagonist is clearly conscious of the difference between Tommies and Canucks. Moreover, the groups of Canadian soldiers that Ramsay and his English relatives encounter constantly in London suggest that Canadianness is not an insignificant, peripheral identity, subordinated to a dominant Englishness. As Vance contends, the transfer of over 600 thousand Canadians to Britain during the war represented a sort of reverse colonialism, a form of Canadianization $(2012,4))^{3}$ It is an interesting notion in the context of The Sojourn, in which the multiple border crossings - territorial, cultural and psychological - might be perhaps conceptualised as metaphorical creolization (see Brah 209-210), decentring and re-inscribing received notions of Englishness/Britishness and situating Britishness as "a Canadian hybrid" (Vance 2012, 4).

\section{Imperial Travellers: The Daughters of Mars by Thomas Keneally}

In The Daughters of Mars, Thomas Keneally explores the story of two Australian sisters, Naomi and Sally Durance, born on a dairy farm in New South Wales, 
who volunteer as military nurses in 1915 . The novel celebrates their courage and endurance, depicting several traumatic incidents, based on historical documentation and Australian nurses' memoirs, such as medical assistance during the Gallipoli campaign, the sinking of a hospital ship, as well as the sisters' heroic work on the island of Lemnos and on the Western front. ${ }^{4}$ It is not so much loyalty to the Empire that pushes the Durance sisters to enlist in the Australian Army Nursing Service as the prospect of freedom and adventure, and, particularly in Sally's case, escape from the limited destiny of an unmarried daughter on an isolated Australian farm. In this sense, for both the protagonists, the war "would alter earthly geography. It altered the geography of duty and it enhanced all escape routes" (Keneally 12). The Daughters of Mars can be approached as a fictional travel book: while documenting the itinerary of Australian nurses during the First World War, from Australia through Ceylon (now Sri Lanka), Egypt, the Dardanelles and Greece to France and back, the novel also explores the theme of horizon-expanding travel and its impact on the traveller's identity. It is worth emphasising that the tropes of tourism and adventure are characteristic of Australian Great War fiction, marking the Australian war experience as both unique and worthwhile (Rhoden 276).

Before Gallipoli, the war is indeed an adventure for the female protagonists: "We're on a wonderful journey and we see marvelous things" (Keneally 48). Sailing on board The Archimedes they acquire much geographical and mythological knowledge about the locations they pass. The ocean crossing is also a delightful time of entertainment, games and dances. ${ }^{5}$ When they cross the equator, a masquerade is organized, for which the nurses prepare their own costumes. During the "initiation into equator hopping," men and women are splashed with water and gracefully submit to other rituals (Keneally 31). Sally, who, because of her more serious disposition and her mother's recent death, prefers not to participate in these "geographical hijinks," reflects on the change in their lives:

most medical officers and orderlies and nurses had been born in Australia and had thought - as Sally had - that the train between Melbourne and Sydney or he coastal steamer from Brisbane might be the greatest journey the world would ever offer them. Yet now here was the equator - the burning and unconsumed filament that divided the world of southern innocence from the world of northern gravity of intent, and the hemisphere of colonists from the hemisphere of the owners. (Keneally 31 )

Such comments, subtly emphasising the unequal global distribution of wealth and power are, however, rare in the novel. By depicting the two sisters sightseeing in British imperial locations and recording their impression in letters sent back home from Asia and Africa, Keneally's fictional travel book does not question the imperial order or European presence in the colonies. The Australian writer applies here what Mary Louise Pratt refers to in Imperial Eyes: Travel Writing and Transculturation as the strategy of anti-conquest, whereby "bourgeois subjects seek to secure their innocence in the same moment as they assert [imperial] 
hegemony" (3). In contrast to the rhetoric of conquest, which exposes the politics and praxis of invasion, anti-conquest stages a seeing (wo)man, "whose imperial eyes passively look out and possess" (Pratt 9). In Colombo, escorted by middleaged British gentlemen, with whom they discuss the changing ownership of the colony, the Durance sisters admire local temples and Buddhas, as well as, though they never approach them, the beautiful inhabitants of the island. The protection of British officials reveals a hidden anxiety about the presence of white women and the fantasy of the colonies as sites of sexual impropriety and excess (Fell 158). The peaceful Port Said contrasts with the crowded, tumultuous Cairo, where for the first time the nurses tend some wounded soldiers and the Syphilisstricken casualties of the city's entertainment district, the Wazzir bazaar. ${ }^{6}$ The sisters watch the local population from a safe distance, exchanging impressions about their exotic customs, habits, indolence and appalling poverty. Anti-conquest "construes seeing as inherently passive and curiosity as innocent" (Pratt 65), while in reality it reaffirms domination. Creating a semblance of self-effacement, these female travellers in fact belong to a world where their racial privilege is taken for granted. The Durance sisters never really wonder about the war's impact on the local population of the British colonies. As a result, the indigenous habitants are constructed as "bodyscapes [...] abstracted away from the history that is being made" (Pratt 63), a history in which they were exploited as cannon fodder and cheap labour, and which deeply affected civilian populations in the most remote parts of the British Empire.

In The Daughters of Mars, rather than a "contact zone" between the white travellers and coloured locals, a social space "where disparate cultures meet, clash, and grapple with each other" (Pratt 7), Cairo becomes a meeting place for Australian men and women, liberated from the moral constraints of home. In Egypt, the sisters develop friendly relationships with young Australian officers, with whom they dine at the luxurious Shepheard Hotel and admire the pyramids and the Sphinx by starlight. Some of these liaisons turn into romances; like the real-life Australian nurses, the Durance sisters and their friends gradually lose their provincial timidity. As Peter Rees reports, "mixing duty with romance in this exotic yet dangerous environment became a focus for many of the nurses" (16). Yet, the nurses watch each other, safeguarding the boundaries of sexual propriety, because for white people in the colonies respectability "was a defense against the colonized and a way of more clearly defining themselves" (Stoler 71). In comparison with this impromptu social life, camel/donkey/horse rides, garden strolls, teas and parties, "to which they were so used now and so worldly at" (Keneally 122), the life on an Australian farm appears increasingly unreal (Keneally 35). Egypt functions therefore as a prelude to the horrors of war, during which the nurses witness suffering and death, but also engage in an active social life, inconceivable back home. This fusion of hard work with exotic delights will characterise their experience in the Middle East. Later in the novel, having delivered 
the Gallipoli casualties to Alexandria, the nurses are offered "an embarrassment of recreations": sightseeing, horse rides, picnics, bathing, parties, thés dansants (Keneally 122). Sally is also given a particularly intense training in visual arts by her sweet-heart Charlie Condon, with whom she visits Sakkara. Consequently, through their perpetual travelling, from provincials living at the antipodes of Empire, the Durance sisters are transformed into cosmopolitans. They acquire an impressive worldliness by participating in a culture of travel, refinement and sophistication (Lionnet 65-67).

Furthermore, in The Daughters of Mars, border crossing and the nurses' dramatic experience as members of the medical staff coincide with radical reinvention of the female self. Although their work during the Gallipoli campaign is deeply traumatizing, at the same time, in spite of the stress and spartan conditions, they manage to save lives and to survive dangerous situations. They are active participants in the war effort, which radically questions "the stereotypical presentation of women as war's 'other"' (Ouditt 1994, 16). Like many real-life Australian nurses, the Durance sisters become more confident and unwilling to accept discrimination (Butler 2003, 54). Their courage and heroism is juxtaposed in the novel with some male characters' lack of control in situations of danger. It is important to note, however, that the sense of independence they acquire as women in the course of their exotic travels, re-inscribes the ideology of anti-conquest, depriving the local population of agency. As Alison S. Fell contends, "white women and colonized men were both constructed as Other in wartime Europe, having the potential to disrupt the binary assumptions upon which white imperial masculinity was constructed" (159). While the daughters of Mars challenge gender norms, ${ }^{7}$ they take for granted the righteousness of the colonial mission and never question the sense of the war or the imperial ideologies sustaining the global conflict.

The sisters' extensive travels also result in a shift in perspective, which reconfigures the relations between Europe and the colonial periphery. Discussing the front-line with her lover Kiernan, Naomi realizes that proportions have altered dramatically: "nothing is distant from anywhere else here. Did you know the entire British line is barely more than a hundred and twenty miles? Melbourne to Beechworth? A great deal of slaughter in a little space, she agreed" (Keneally 341). Moreover, when a French Quaker is surprised that there are Friends in a remote place like Melbourne, Naomi comes to the conclusion that "the same could be said for Paris" (Keneally 368). In the chapter tellingly entitled "Cosmopolitans," sightseeing with her friends in Paris, Sally is surprised by her mature reactions to the paintings at the Louvre, which are the effect of her earlier artistic experience in Africa. The comparisons she makes while visiting Notre Dame reveal the cosmopolitan insight of a world traveller: "Like the pyramids, the cathedral could be approached by ordinary steps taken by one's daily legs - the same legs with which one emerged from Kempsey's Barsby's Emporium and crossed Belgrave 
Street to Mottee's Tearooms" (Kenneally 280). If initially their Australianness represented a certain deficit, at the closure of the novel, the protagonists' insularity seems to have disappeared, replaced by worldliness, maturity, culture and knowledge.

Significantly, in The Daughters of Mars the Durance sisters' newly acquired cosmopolitanism is compatible with their imperial nationalism. The Australian characters are proud of their antipodean identity and will not tolerate being patronized by the British. While the conviction that "each Australian was worth a number of the others" (Keneally 283) proves naïve in the realities of slaughter, the Durance sisters retain a quiet pride about Anzac difference within the Empire. Furthermore, Australianness is foregrounded as an artistic theme in Sally's discussions with Charlie, who is a painter. Admiring collections of European art in French galleries, he comes to the conclusion that this art is incompatible with the demands of Australian landscape: "It's all so different from here. It's not Europe. It's non-Europe. And always will be" (Keneally 399). The vastness and sublimity of Australia contrasts radically with the harmonious, well-ordered French countryside; the amazing colours of Australian nature "would explode Cézanne's palette" (Keneally 398). Charlie's dilemmas echo the ideas of Australian Impressionists, known as the Heidelberg School, and their search for an emergent Australian identity and aesthetics (Introduction to Australian Impressionism; Gray 11-12). The novel closes with an art exhibition, in which the grim paintings inspired by war are more noticeable than the Australian landscapes. This art combines local and global sources of influence, provincial and cosmopolitan ones. In a metafictional way, Keneally points to his own literary project - creating a First World War novel with a distinct Australian flavour, yet appealing to an international audience. The closing scene throws into relief the radical impact of the global conflict on Australian culture. War's transformative power - in terms of individual and group identities at the periphery of the Empire - is thus highlighted as the central theme of The Daughters of Mars.

\section{Critical Cosmopolitans: Blue Ravens by Gerald Vizenor}

In Blue Ravens: Historical Novel, Anishinaabe writer and critic Gerald Vizenor, relying on the life-stories of his great-uncles from the White Earth Reservation, Becker County, in north-central Minnesota (Vizenor 2013), imagines two Chippewa soldiers, Basile and Aloysius Hudon Beaulieu, who serve in the American Expeditionary Forces during the First World War. Border crossing is present in the novel on the levels of content and form, since Vizenor mixes genres and styles by referring to his theoretical essays and blurring the borderline between fiction and history. Furthermore, the elusive concept of Native liberty or survivance, which Vizenor defines in his critical work as "the union of active survival and resistance 
to cultural dominance" $(2009,24)$, is at the centre of the text. Blue Ravens is the fruit of extensive archival research; the writer insists that it is a historical novel and not pure fiction (Vizenor 2013). Although the narrator is Basile, who creates stories-within-stories, fragments of the text, the descriptions of combat at Château-Thierry and Montbréhain in particular, are composed in an impersonal style similar to historical discourse.

Blue Ravens shows that, in spite of the provisions of the American Selective Service Act, according to which Native Americans could claim exemption from the draft, all Natives "were ready for the adventure of combat, not for a passive alien exemption of service in the Great War" (Vizenor 2014, 94). Historical sources confirm that, although most Native Americans living on reservations were not yet recognized as citizens of the United States (Morris and Morris 626), they were eager to serve to maintain warrior traditions and prove their courage and loyalty by the side of white men (Winegard 8). Blue Ravens includes long lists of war casualties from Becker Country with a succinct comment on the circumstances and site of their death, a historic(al) roll of honour incorporated in a fictional narrative. Puzzling to the Western reader, these Native names have an important function, for they "create a sense of presence, a tease that undermines the simulations of absence and cultural dominance" (Vizenor 2009, 5). Although it focuses on the sequels of colonisation, war trauma and death in the war zone, Blue Ravens resists the spirit of victimry (Vizenor 2009, 24) by commemorating the courage and sacrifice of the indigenous community during the 1914-1918 conflict.

Most importantly, the characters of the novel are not "Dead Indians," relics of the past, surrounded by the exotic signifiers of a dying culture (King 53-54), but active agents of resistance who transform their tribal inheritance for the modern age. Vizenor uses the tropes of mobility, border crossing and worldliness to challenge the stereotypical, colonial depictions of static and isolated Indian lives. The community of the White Earth reservation edit their own newspaper which informs them about local, national and international news, including that of war, long before the draft. ${ }^{8}$ To sell this weekly newspaper, Aloysius and Basile travel on the railroad as far as Minneapolis. The two brothers live close to nature and partake in indigenous rituals; at the same time, they are creative artists, Aloysius - a painter, Basile - a writer, interested in Western literature and visual art. On a visit to Minneapolis, Aloysius approaches Yamada Baske, an established Japanese painter, to discuss the visionary blue ravens he creates. Having been offered a tin of watercolour paint by the older man, he follows his suggestion and adds a slight touch of rouge to the scenes of blue ravens. Totemic art is enriched by Baske's impressionism, combined with traditional Japanese painting styles. Vizenor highlights the transformative power of the creative act, which fuses several cultural traditions. Through their extensive readings, the influential encounter with the Japanese artist, and the contact with the global world provided by the reservation newspaper the protagonists develop "cosmopolitan sensibilities [...] 
attuned to patterns of contact, exchange" and movement (Lionnet 91) long before they leave for France.

However, if Vizenor explores the impact of various cultural traditions on his protagonists, he also stresses how they reinterpret the reality within the inherited frames of ancestral cultures. In a way surprising to the reader, it is Homer's The Odyssey, the foundational classic of European culture, that becomes Basile's "literature of native memories and endurance in the war" (Vizenor 2014, 103). At the same time, the blue ravens painted by Aloysius and the tricky stories created by Basile are "the crucial totems and portraits" of their experience at the European front (Vizenor 2014, 20). Basile imagines the Kaiser as an ice monster, a relative of the ice woman in the Anishinaabe mythology. Significantly, if in Blue Ravens war changes familiar Native stories (Vizenor 2014, 115), the universe of war is transformed by Native visions, too:

We were brothers on the reservation, brothers in the bloody blue muck of the trenches, slow black rivers, brick shambles of farms and cities, brothers of the untold dead at gruesome stations. Bodies were stacked by the day for a wretched roadside funeral in the forest ruins. We were steadfast brothers on the road of lonesome warriors, a native artist and writer ready to transmute the desolation of war with blue ravens and poetic scenes of a scary civilization and native liberty. (Vizenor 2014, 8)

Yet, visions of glory are soon replaced by vistas of ruins and desolation, as well as descriptions of mutilated bodies. In the trenches, the two brothers are selected as scouts for particularly dangerous missions, because their commander believes that "stealth [is] in [their] blood" (Vizenor 2014, 121), an opinion commonly shared by white officers during the First World War (Winegard 114). He also treats them as dispensable cannon fodder to spare white lives. While in the novel Native Americans prove to be excellent soldiers, they also use their skills to protect themselves and their companions. War paint highlights the colonial fantasy of the savage warrior and helps them scare German soldiers into surrender, yet it also functions as a ritual of camouflage and survival. For Vizenor, the view of Native soldiers as victims of a callous military is too limiting; the novel highlights the "quality of action" inherent in survivance (see Vizenor 2009, 100). However, Aloysius and Basile's experience at the front is depicted in a succinct, economic manner, which, on the one hand, as noted above, is reminiscent of historical documentation, and, on the other hand, subtly renders the mental wounds they sustained in combat. Basile in particular suffers from dreadful nightmares and flashbacks.

Interestingly, the return to the U.S. is traumatic for the protagonists of Blue Ravens. While they "were both inspired by the mystery, anxiety, and irony of the passage to war," the return to the reservation "was neither peace nor the end of war" (Vizenor 2014, 169). For the Native American characters, the Great War is not a chasm that fractures a peaceful existence (Hynes 1990: xi), but an event that only adds new facets to the trauma of federal occupation on the reservation. 
Back home, they are neither able to create nor to find employment. Both feel uneasy about the Americans' misuse of patriotism and honour in the post-war years. Moreover, they miss their furlough in Paris, during which they were deeply impressed by the architecture and atmosphere of the French capital. This is why, having learnt of the success of Aloysius's paintings at the Galerie Crémieux in Paris, they decide to go back to France. The Great War thus causes them to question the relation between the local and the global, and to detach themselves from their American homeland, as they become more aware of racial exploitation and injustice at home, and the opportunities offered by the French metropole: "we were exiles on a federal reservation but not as soldiers, and we were never exiles in Paris. So, we were expatriates in the City of Light, in the city of avant-garde art and literature. Paris was our sense of presence and liberty" (Vizenor 2014, 256).

The two brothers' post-war years in Paris are represented in Blue Ravens as a profound immersion in cosmopolitan culture. Vizenor stages their encounters with various real-life celebrities, such as, for instance, a rather hostile James Joyce, Marc Chagall, who is fascinated by Aloysius's paintings, and Marie Vassilieff, who becomes Basile's lover. They discuss art, literature and politics with the avantgarde artists of Europe, exposing "the contradictions and ironies of radical politics and aesthetics between the White Reservation and Le Chemin du Montparnasse in Paris" (Vizenor 2014, 225). The Goldenberg Delicatessen on Rue des Rosiers becomes their favourite restaurant, where, teased by the owner, they order goulash, herring or latkes. Furthermore, in Blue Ravens, the community of Native expatriates meet at the Café du Dôme, the legendary Montparnasse mecca of poets, writers, painters, sculptors and art connoisseurs. The Native American protagonists can be thus seen as Dômiers in their own right, like Hemingway, Picasso or Lenin, whom Aloysius ironically recomposes as carnivalesque blue ravens in his paintings. ${ }^{9}$ Like the "international modernists" (Walkowitz 2), Vizenor's protagonists oppose sterile traditions: their survivance narratives question the romanticized clichés of Indians as products of imperial cultures and objects of ethnographic research. As a result, they become representatives of what Walkowitz defines as critical cosmopolitanism, "comparing, distinguishing, and judging among different versions of transnational thought; testing moral and political norms, including the norms of critical thinking; and valuing informal as well as transient models of community" (2).

Significantly, the two brothers' creative work transforms the Parisian avantgarde community. Not only do Aloysius's blue ravens revolutionize native art, but his new school of art, known as École Indienne, changes the shape of modernism. In fact, his paintings, exhibited at the Crémieux gallery, are viewed as a unique form of expressionism, compared to the abstract works of Georges Braques, Pablo Picasso and Marc Chagall. Basile's stories are translated and published in French; the applauded Le Retour à la France: Histoires de Guerre functions as a miseen-abime, reduplicating the war episodes in Vizenor's (post)modern text. While modernism is traditionally approached in terms of established dichotomies, such 
as, for example conventional/experimental, nation/world, centre/margin (Platt 3), Blue Ravens moves beyond such definitions by staging mutual exchanges between white and indigenous artists. Importantly, indigenous culture is not simply appropriated in the novel by the metropole in search for spiritual regeneration. The syncretic dynamic of the literature and art created by the protagonists "critically appropriates elements from the master-codes of the dominant culture and creolizes them, disarticulating the given signs and rearticulating their symbolic meaning otherwise" (Mercer 255). Thus, in a radical gesture, Vizenor reconfigures the Native American artists as modernists per se, their creative work an important source of inspiration for the metropolitan elites. This carnivalesque vision of exchanges and continuities between the cultures of the imperial centre and the periphery thereby undermines the cliché of "modernism as a prestige culture of the "West"' (Platt 2).

In Blue Ravens, the First World War is a catalyst of global change: "The Great War fractured the ordinary stay, wily scenes, native reflections, ethnographic warrants, and empire cultures, and nothing has ever been the same on the White Earth Reservation, Montbréhain, Rue Mouffetard, or the River Seine" (Vizenor 2014, 248). The post-war Paris depicted in the novel becomes a genuine contact zone, a space of transcultural encounters in which subjects whose trajectories intersect "get constituted in and by their relations to each other" (Pratt 8). Aloysius's and Basile's identities evolve towards a form of hybridity, metaphorical creolization, fusing indigenous oral traditions with "a highly literate, urbane and enlightened polity" (Lionnet 69), yet simultaneously influencing the mainstream culture as well. In fact, the relationship between cosmopolitanism and creolization, usually seen as its peripheral opposite, is reconfigured in Blue Ravens, which seems to redefine "creolization as the cosmopolitanism of the subaltern, and cosmopolitanism as the creolization of the elites" (Lionnet 65). Nevertheless, it is important to emphasise that the protagonists of Vizenor's novel discover deep affinities with other migrant characters, Jews, facially mutilated soldiers, impoverished war veterans, war widows and their orphaned children, all tragic victims of a global conflict. Vizenor proposes a vision of an inclusionary cosmopolitanism (Anderson 71-72), based on a paradigm of universal humanity, an openness to the elites, as well as to the powerless. Importantly, in Blue Ravens, the Great War not only proves to be a revolutionizing force, but the source of tragedy, trauma and death, yet also the factor that breaks geographical, epistemological and ontological barriers and recomposes conceptual, ethical and artistic frontiers.

\section{Conclusion}

In the three novels under consideration the First World War involves the colonial travellers in territorial, psychological, cultural and political border crossings, which cause them to redefine their colonial loyalties and their place in the British 
Empire. While in the pre-war period travel was a privilege of the (white) elites, in Alan Cumyn's, Thomas Keneally's and Gerald Vizenor's novels, the Great War introduces, despite its huge costs, a sort of egalitarianism that allows the colonial protagonists to become tourists, cosmopolitans and/or critical observers of the metropole. Cumyn's The Sojourn explores the dichotomy between the colonial centre and margin by highlighting intricate imperial clichés shaping the dynamic of the colonial encounter. While the English characters of the novel continue to view Canadianness as inferior and subordinate, the Canadian protagonist situates Englishness in a critical light. The reverse migration of Canadians to the Mother Country, as depicted by Cumyn, illustrates a uniquely Canadian attachment to the British liberal ideals, which, however, moves beyond the parent-child metaphor towards an idiosyncratic hybrid vision of Britishness. Whereas the English characters consider the war essentially an imperial project, the Canadian protagonist is motivated by ideas of freedom and comradeship, which his class-defined relatives are incapable of understanding. The novel thus exposes the minoritizing and peripheralizing mechanisms typical of cultures of dominance (see Brah 210), and the creolizing efforts of minority cultures to resist such domination.

In The Daughters of Mars, Keneally depicts Australian nurses discovering the complex, territorial and political cartography of the Empire. The global conflict allows the two sisters to travel, Odysseus-like, all over the colonial world and visit "exotic" locations, in comparison with which Australia appears dull and mundane. Faithful to historical documentation, the novel illustrates the Australian women's often marginalised war effort and their subsequent critique of gender norms, yet Keneally fails to provide radical visions of inter-racial alliances between his female protagonists and the colonial populations they encounter on imperial routes. Their worldliness is a form of exclusionary cosmopolitanism, in which "no weight is given to exploration of disparate cultures" (Anderson 73). Consequently, the Durance sisters' emancipation - as women and peripheral subjects of the Empire - coincides with an acceptance of the values of the metropole and active participation in the imperial project.

By contrast, the cosmopolitanism of Vizenor's Native American protagonists is inclusionary, characterised by a "sympathetic imagination and intercultural exchange" (Anderson 73). The most radical of the texts under consideration, Blue Ravens offers a revolutionary vision of colonial encounters, which result in a critique of imperialism, a deconstruction of Western epistemological privilege, and a challenge to a conception of modernism as an exclusively Western phenomenon. While commemorating the Native Americans' contribution to the war effort, Vizenor exposes the hypocritical policies of the American government which used its indigenous population as cannon fodder but was unwilling to recognize their war sacrifice. However, far from portraying his characters as passive victims of the cruel conflict, the novelist depicts them as active agents, reshaping cultures and selves through their narratives of survivance. Distancing 
himself from a conception of war end as closure, Vizenor also rethinks the relation between cosmopolitanism and creolization in the new socio-political (dis-) order of global migrations that emerged after the Armistice.

The three novels under consideration engage with war trauma and its devastating sequels, yet at the same time they focus on the transformative power of displacement caused by war, and radically depart from the cliché of static trench warfare. Situating the Great War in a postcolonial perspective, they explore previously neglected experiences and ideologies. As a result, the first global war is reconfigured in terms of mobility, contact and/or transnational encounters, which cause radical shifts in consciousness, as well as aspirations for cultural/ political autonomy. Questioning the view of war as a privilege for the peoples of the imperial peripheries, The Sojourn, The Daughters of Mars and Blue Ravens also echo twenty-first century concerns with national identity, cosmopolitanism and creolization. Published approximately a hundred years after the 1914-1918 conflict, the three texts thus testify to the Great War's continuing potential to inspire new and thought-provoking ethical and aesthetic projects.

\section{Acknowledgements}

This research was supported by grant DEC-2013/11/B/HS2/02871 from the Polish National Science Centre (Narodowe Centrum Nauki).

\section{Notes}

1 I analyse these contrasts in more detail in Branach-Kallas 2015.

2 The drawings that Ramsay sends Margaret from the war zone once he comes back to the front highlight the role of the soldier-artist "as truth teller, as the seer who has both the unique capacity and the sacred obligation to expose the war for what it is" (Gordon 102). In The Famished Lover, a sequel to The Sojourn, Cumyn depicts Margaret, unhappily married to Boulton, longing for Ramsay in the post-war years.

3 According to Vance, long considered an immature phase in Canada's colonial past, the British connection has only recently been recognized as an important part of Canadian identity. For Vance, the establishment of Canadian outposts in Great Britain during the First and the Second World Wars was one of the most significant mass migrations of the twentieth century: "In the eighteenth and nineteenth centuries, Britain came to Canada and helped to shape the nation as a critical part of the British Empire. In the twentieth century, Canada went to Britain and established, at least for a time, a Maple Leaf Empire" $(2012,4)$. 
4 Keneally both questions and re-inscribes the Australian legend of the Anzac. I analyse the "Anzac" themes as well as Keneally's representation of nursing sisters in "Misifts of War: First World War Nurses in The Daughters of Mars by Thomas Keneally," where I argue that, while including the Australian nurses in the Anzac mythology, Keneally's novel does not interrogate Australian women's support for the imperial war.

5 In his descriptions of the sisters' adventures Keneally relies, to a large extent, on Peter Rees's popular history, Anzac Girls: An Extraordinary Story of World War I Nurses.

6 As Rees reports, "By the early months of 1915 the ranks of local and foreign prostitutes in the Egyptian capital had swelled to accommodate the leave-time needs of the Anzacs." Within a fortnight, there was an outburst of venereal disease, which eventually led to serious riots in the Wazzir (36). Neither Rees nor Keneally mentions the impact of these events on the local population.

7 See Branach-Kallas 2017 for an extensive analysis of gender roles in Keneally's novel.

8 For the history of this "cosmopolitan" reservation newspaper, see Vizenor 2009, 35-5.

9 On the writer's attitude to Bakhtin's dialogical thought, see Vizenor 1995, 147.

\section{References}

Anderson, Amanda. 2006. The Way We Argue Now: A Study in the Cultures of Theory. Princeton and Oxford: Princeton University Press.

Brah, Avtar. 1996. Cartographies of Diaspora: Contesting Identities. London and New York: Routledge.

Branach-Kallas, Anna. 2015. "Narratives of (Post-) Colonial Encounter: The Old World in Contemporary Canadian Great War Fiction." North America, Europe and the Cultural Memory of the First World War. Ed. Martin Löschnigg and Karin Kraus. Heidelberg: Universitätsverlag WINTER. 95-106.

Branach-Kallas, Anna. 2017. "Misfits Of War: First World War Nurses in The Daughters of Mars by Thomas Keneally." Studia Anglica Posnaniensa 52. 4: 409-426. https://doi.org/10.1515/stap-2017-0018

Butler, Janet. 2003. "Nursing Gallipoli: Identity and the Challenge of Experience." Journal of Australian Studies 27. 78: 47-57. http://dx.doi. org/10.1080/14443050309387870

Cumyn, Alan. 2003. The Sojourn. Toronto: McClelland \& Stewart.

—. 2006. The Famished Lover. Fredericton, New Brunswick: Gross Lane Editions.

Das, Santanu. 2013. "Introduction." Race, Empire and First World War Writings.

Ed. Santanu Das. New York: Cambridge University Press. 1-32. 
Fell, Alison S. 2013. "Nursing the Other: the Representation of Colonial Troops in French and British First World War Nursing Memoirs." Empire and First World War Writings. Ed. Santanu Das. New York: Cambridge University Press. 158-174.

Fussell, Paul. 1975. The Great War and Modern Memory. New York and London: Oxford University Press.

Gordon, Neta. 2014. Catching the Torch: Contemporary Canadian Literary Responses to World War I. Waterloo: Wilfrid Laurier University Press.

Gray, Anne. 2002. "Introduction." Australian Art in the National Gallery of Australia. Ed. Anne Gray. Victoria, London, Seattle: National Gallery of Australia. $10-19$.

Hynes, Samuel. 1990. A War Imagined: The First World War and English Culture. London: The Bodley Head.

Introduction to Australian Impressionism. National Gallery of Victoria. http:// www.ngv.vic.gov.au/australianimpressionism/education/insights_intro.html

Keneally, Thomas. 2013. The Daughters of Mars. New York, London, Toronto, Sydney, New Delhi: Atria Books.

Keshen, Jeff. "The Great War Soldier as Nation Builder in Canada and Australia." Canada and the Great War: Western Front Association Papers. Ed. Briton C. Busch. Montreal and Kingston, London, Ithaca: McGill-Queen's University Press. 3-26.

King, Thomas. The Inconvenient Indian: A Curious Account of Native People in North America. Toronto: Anchor Canada.

Lionnet, Françoise. 2012. Le su et l'incertain. Cosmopolitiques créoles de l'océan Indien / The Known and the Uncertain. Creole Cosmopolitics of the Indian Ocean. La Pelouse, Trou d'Eau Douce, Ile Maurice: L'Atelier de l'écriture.

Mercer, Kobena. 2003. "Diaspora Culture and the Dialogic Imagination: The Aesthetics of Black Independent Film in Britain." Theorizing Diaspora: A Reader. Ed. Jana Evans Braziel and Anita Mannur. Malden, Oxford, Victoria: Blackwell Publishing. 247-260.

Morris, Jeffrey B. and Richard B. Morris, ed. 1996. Encyclopedia of American History. Seventh Edition. New York: HarperCollins Publishers.

Olusoga, David. 2014. The World's War. London: Head of Zeus.

Ouditt, Sharon. 1994. Fighting Forces, Writing Women: Identity and Ideology in the First World War. London and New York: Routledge.

Platt, Lenn. 2011. Introduction to Modernism and Race. Ed. Lenn Platt. Cambridge: Cambridge University Press. 1-18.

Pratt, Mary Louise. 2008. Imperial Eyes: Travel Writing and Transculturation. London and New York: Routledge.

Rees, Peter. 2009. The Other Anzacs: The Extraordinary Story of Our World War I Nurses. Crows Nest: Easyread Large.

Rhoden, Clare. 2014. "Even More Australian: Australian Great War Novels in the Twenty-First Century." The Great War in Post-Memory Literature and Film. 
Ed. Martin Löschnigg and Marzena Sokołowska-Paryż. Berlin and Boston: De Gruyter. 273-288.

Stoler, Ann Laura. 2002. Carnal Knowledge and Imperial Power: Race and the Intimate in Colonial Rule. Berkley, Los Angeles, London: University of California Press.

Trotter, David. 2005. "The British Novel and the War." The Cambridge Companion to the Literature of the First World War. Ed. Vincent Sherry. Cambridge: Cambridge University Press. 34-56.

Vance, Jonathan F. 1997. Death So Noble: Memory, Meaning and the First World War. Vancouver: University of British Columbia Press.

—. 2012. Maple Leaf Empire: Canada, Britain, and Two World Wars. Don Mills: Oxford University Press.

Vizenor, Gerald. 1995. "Interview with Helmbrecht Breinig and Klaus Lösch." American Contradictions: Interviews with Nine American Writers. Ed. Wolfgang Binder and Helmbrecht Breinig. Middletown, Connecticut: Wesleyan University Press. 144-165.

-. 2009. Native Liberty: Natural Reason and Cultural Survivance. Lincoln and London: University of Nebraska Press.

—. 2013. "White Earth Montbrehain: Native American Indians in the First World War." Lecture at the University of Michigan, May 11. http://blueravens.site. wesleyan.edu/audio-video/

—. 2014. Blue Ravens: Historical Novel. Middletown, Connecticut: Wesleyan University Press.

Walkowitz, Rebecca L. 2006. Cosmopolitan Style: Modernism Beyond the Nation. New York: Columbia University Press.

Winegard, Timothy C. 2012. For King and Kanata: Canadian Indians and the First World War. Winnipeg: University of Manitoba Press.

Winter, Jay. 2015. "Families." The Cambridge History of the First World War. Vol. 3: Civil Society. Ed. Jay Winter. Cambridge: Cambridge University Press. 46-68. Cambridge Histories Online. http://universitypublishingonline.org/ cambridge/histories/ 
Rūta Šlapkauskaite

(iD https://orcid.org/0000-0001-9223-002X

Vilnius University

\title{
"Like being trapped in a drum": The Poetics of Resonance in Frances Itani's Deafening
}

\begin{abstract}
This paper considers how Frances Itani's Deafening imaginatively rethinks our understanding of the Great War in the age of postmemory. Seeing as the novel is set in Canada and Europe during the First World War and takes as its protagonist a deaf woman, the poetic attention given to the senses as a horizon of phenomenological experience magnifies the moral bonds that the characters establish in defiance of both deafness and death. Guided by the theoretical reasoning of Marianne Hirsch, Elaine Scarry, and Alison Landsberg as well as contemporary phenomenological thinking, most significantly that of Edward S. Casey, Steven Connor, Michel Serres, and Jean-Luc Nancy, this paper examines how the novel's attentiveness to the materiality of the body in regard to the ethical collisions of sound and silence as well as life and death contributes to a poetics of resonance that generates prosthetic memories, turning the anonymous record of war into a private experience of moral endurance inscribed on the ear of historical legacy.
\end{abstract}

Ours is an age without trumpets.

We can now receive the gift of language,

because we have silenced the world.

(Michel Serres, The Five Senses. A Philosophy of Mingled Bodies)

Fictional accounts of the historical experience of the Great War in Frances Itani's Deafening intertwine with a poetic attentiveness to the cultural construction of deafness in the narrative structure of memory. Consistent with using deafness as a trope of phenomenological relationality, a narrative conceit that binds the notion of silence to signification, this novel raises concerns about how embodied experience set in the past may be translated into embodied knowledge in the present. By taking issue with the dichotomy of sound vs. silence characterising the dominant Western discourse on deafness, I examine how Itani's novel reconfigures the perceptual parametres of disability, so that both deafness and war injury connect to the body as a sentient source of textuality. In this respect, the 
concept of disability itself can be thought of not only as a physical, but also as an epistemological, condition, one that recognises the moral implications of writing about the First World War in the twenty-first century.

\section{Writing Postmemory}

Like any work of art concerned with making sense of the past, historical fiction is grounded in the act of interpretation that measures facticity against the light of invention. At the heart of this enterprise we find an irresolvable preoccupation with referentiality and representation, testing the premises of our assumptions about truth and epistemological authority in the relation between mimesis and diegesis, experience and language. Nowhere has this been more foregrounded than in postmodern literature and theory, whose intellectual avenues have converged in Linda Hutcheon's notion of "historiographic metafiction" (20) characterising novels like Michael Ondaatje's The English Patient or Margaret Atwood's The Blind Assassin. The collapse of old epistemological certainties in the second half of the twentieth century, which marked the ascendance of what Jean-François Lyotard diagnosed as "the postmodern condition" commensurate with "incredulity toward metanarratives" (xxiv), echoed in the rise of a new sense of narrative responsibility, one that was keen to debunk the idea of aesthetic sovereignty embraced by High Modernism and acknowledge the act of creation as political praxis. Hutcheon's theorising of postmodern poetics reflecting the internal contradictions of postmodern culture and the overlaps and confrontations between "various kinds of theory and current literary discourse" (15) highlighted the shift in the conceptualisation of historiography itself as a narrative means through which the past is given social meaning continuous with the dominant system of values underlying the ongoing cultural processes.

While borrowing from Hayden White's reasoning about history as narrative, Hutcheon's emphasis on the constructedness, rather than givenness, of historical truth brought to our attention the ideological links between history and fiction as signifying processes, which need to recognise their complicity in discursive networks that constitute the institutional mechanism of the legitimation of knowledge and power. To quote Hutcheon,

what postmodernism does is to contest the very possibility of our ever being able to know the "ultimate objects" of the past. It teaches and enacts the recognition of the fact that the social, historical, and existential "reality" of the past is discursive reality when it is used as the referent of art, and so the only "genuine historicity" becomes that which would openly acknowledge its own discursive, contingent identity. (24)

In this view, what is key to postmodern literature's engagement with history is its emphatic awareness of the problematic nature of reference and the production 
of knowledge, resulting in a formal and ideological self-reflexivity that deploys (inter)textuality simultaneously to question the ways in which human subjectivity enters into contract with social norms and institutions and to maintain the recognisability of the dominant social order. A measure of significance is also derived from giving voice to "the ex-centrics, the marginalized, the peripheral figures of fictional history" (Hutcheon 114), whose presence in official historical record is routinely obliterated by the need to install a totalising structure of a single, "objective" truth. By drawing our attention to marginalised subjectivity, historiographic metafictions open up the epistemological gap between modes of memory and institutional inscriptions of historical experience, achieved often at the cost of the suppression of difference in terms of race, gender, sexuality, able-bodiedness, or age. In a figural system where emphasis is placed on the narrative act as a means of production of knowledge, the ex-centric subject offers a necessary degree of critical distance and resistance to ideological absorption when examining the signifying practices that bring the epistemological remoteness of the past into the hermeneutic fold of the present. Among other things, the ex-centric body intervenes into the economy of meaning where cognition is divorced from corporeality and highlights the correlations between memory and the lived experience that bear on our sense of self as both historical and political agents. While capable of ideological subversion, however, the ex-centric characters in the novels like Salman Rushdie's Midnight's Children or Susan Swan's The Biggest Modern Woman of the World do not stage a simple inversion of centre and margin in the dynamics of power. Instead, their ex-centric lens warps the dominant perception of past events and invites us to rethink the culturally operative categories of meaning which build the illusion of transparency surrounding the distinctions between fact and fiction, art and theory, social action and discourse. As Hutcheon insists, "To be ex-centric, on the border or margin, inside yet outside is to have a different perspective, one that Virginia Woolf [...] once called 'alien and critical,' one that is 'always altering its focus,' since it has no centering force" (67). This is why in postmodern theory and fiction historiography itself emerges as a discursive practice of ideological containment, which achieves institutional validity by eliding narrative contradictions, material contingencies, and disruptive singularities.

As an aesthetic mode of historical consciousness that attends to the agency of the body in the world, historical fiction entails a hermeneutic imperative to, what Hans-Georg Gadamer calls, being "sensitive to the text's alterity" (271), calling for an ethical engagement with our assumptions about the texture of the past and the irreducibility of its meaning. War fiction, in particular, thinks in conjunction with the body, attending to the vicissitudes of trauma in the aftermath of military confrontations and physical and emotional violence. David Trotter has made a similar point in commenting on the British novels about the Great War in The Cambridge Companion to the Literature of the First World War, noting 
that: "The First World War was a psychiatric as well as a literary war, and after it there may have been some collusion between these two ways of thinking about distress of mind" (49). This is to say that the appeal the Great War had to the literary imagination of the writers who lived in its proximity contributed to the expansion of the medical understanding of the complexity of moral and perceptual fibre of which the human body and consciousness are capable.

This has had important implications for contemporary literary reflections on war, especially in the "postmemory" (Hirsch 5) context of the centennial commemorative discourse linked to the legacy of the Great War. Commemoration, as philosopher Edward S. Casey reminds us, entails soliciting body and place in a communal effort to overcome "the separation from which otherwise unaffiliated individuals suffer" (250). The oscillation between continuity and rupture, connectivity to and recollection of the past in commemorative work brings into view the ethical dimension of the process of transmission that underlies the practices of cultural signification in the public domain. Given its conceptual reach beyond the "affiliative structures of memory" (21) bound to a single generation, Marianne Hirsch's notion of postmemory seems particularly intellectually rewarding in how we approach acts of remembering that constitute contemporary historical fiction. Crucially, it untangles the conceptual knot of the problem faced in transgenerational acts of memory transfer: "Postmemory' describes the relationship that 'the generation after' bears to the personal, collective, and cultural trauma of those who came before - to experiences they 'remember' only by means of the stories, images, and behaviors among which they grew up" (5). For Hirsch, postmemory offers a "structure of inter- and transgenerational return of traumatic knowledge and embodied experience" (5-6), which can be enacted through affective relationships to "testimonial objects" (24) that demand recall as much as "imaginative investment, projection, and creation" (5). How this bears on the literary scene is that unlike the verbal testimonies of, for example, Wilfred Owen or Robert Graves, who not only took part in combat, but also spoke to the readers directly affected by it, postmemory narratives signal "the absence of a first-hand empirical connection to the war" (Sokołowska-Paryż and Löschnigg 1) and thus face the problem of interpretation that involves responding not only to the epistemological distance that separates us from the immediacy of WWI, but also to the hermeneutic tradition through which the past addresses our current age. In other words, postmemory fiction is bound to the principle of reciprocity, wherein contemporary reflections on the past make manifest our conceptual situatedness in interpretative practices. Gadamer explains this process in terms of tradition:

$[\ldots]$ our usual relationship to the past is not characterized by distancing and freeing ourselves from tradition. Rather, we are always situated within traditions, and this is no objectifying process - i.e., we do not conceive of what tradition says as something other, something alien. It is always part of us, a model or exemplar, a kind 
of cognizance that our late historical judgment would hardly regard as a kind of knowledge but as the most ingenuous affinity with tradition. (283)

In regard to postmemory literature about the Great War, writing involves revisiting forgotten sites of lived experience, restoring the silenced (material) accounts, and revising the authoritative readings of historical records. Not only does this attempt demand understanding the complex political nature of past events in relation to the present, but also calls for ascribing meaning to experience and thus converting, by way of narrative means, empirical horror, the ordeals of the body, and the shortcomings of (post)memory into a mode of aesthetic encounter. It is in this light that Marzena Sokołowska-Paryż and Martin Löschnigg observe in their "Introduction" to The Great War in Post-Memory Literature and Film that "Post-memory literature and film reinterpret and redefine the Great War but - at the same time - they create and perpetuate an emphatic connection with this past, and endow it with a significance for the present" (3).

The commemorative gesture of postmemory literature about WWI poses its own set of conceptual problems. One of them has to do with thinking about fiction as a place of memory where the durability of remembrance invested in material pages is shaped through the metaphorical act of resurrection, which is premised on the cultural rite of entombment. If we accept Robert Pogue Harrison's phenomenological reasoning that "the act of blackening the page constitutes a gift of the dead to the future" (14), then we may forge an analogy between the earth, into which we submit our dead, and narrative texture that stores our being in time. This is to say that as a testament to human finitude, literature makes a pledge to the soil, humus, which conceives human subjectivity and houses mortal time, so that we can partake of the heirloom of the past and stand in the guardianship of cultural memory. To reiterate Pogue Harrison's insight, literature evokes a burial place, which "marks the mortality of its creators even more distinctly than it marks the resting place of the dead" (20). Attendant upon this commemorative act, the war novel becomes a receptacle of (post)memory, whose material form - a monumentality of a kind - is elevated to a communal, public event inscribed with symbolic value that is suggestive not only of a moral bond between the present and the past, but also of the power of material commemoration to transcend death. This goes in step with Casey's observation that "commemoration, in honouring the past, revivifies the present, giving it a new birth - whether of a political or of a spiritual nature" (237; original emphasis). In other words, the act of collective remembrance furnishes the agents of memory with a new capacity for life that sustains hermeneutic links between the living and the dead, the individual minds and bodies and the places they inhabit, and, ultimately, human interiority and the shared practices of meaning-making that belong to cultural life. As a site of embodied remembrance, the postmemory war novel unfolds a reciprocal relation between art and its recipients that may be compared to the intellectual and 
emotional significance of monuments as described by philosopher Dylan Trigg in The Memory of Place:

The individual human subject stands before the monument. The object is neither passive nor indifferent to the viewer. But nor is the meaning of the interaction clear from the outset. A relation between self and world opens, whereby the monument not only empowers itself as transcending death, but also presents itself as an object to empower the viewer as a finite entity. Thanks to this dynamic, affective experience is framed by the aesthetic attributes of the monument. The monument becomes a site of affirmation and introspection, at once pointing to the anonymity of death but also to the singularity of individual finitude. (93)

Key to the phenomenological significance Trigg reflects on is the relay of intersubjective experience made possible by the aesthetic properties of the monument that structure the commemorative act-event. The materiality of the monument is shown to be able to accommodate both the shared knowledge of human mortality and the individual sensitivity to finitude as a source of signification.

I hope it is not too far-fetched to suggest that the power of durability and singularity Trigg finds in monuments can be extended to written accounts, which, as Pogue Harrison incisively puts it, are made of "this conservative element that outlasts its bygone worlds even as it allows for the opening of crypts and folds of human time in the midst of nature's transcendence" (15). It seems to me that postmemory literature, in particular, recalibrates the past as a human foundation at the same time as it occasions a reflection on "the singularity of individual finitude." Especially so as Trigg's reasoning aligns with Derek Attridge's observations about singularity as a seed of creative imagination:

[...] singularity, like alterity and inventiveness, is not a property but an event, the event of singularizing which takes place in reception: it does not occur outside the responses of those who encounter and thereby constitute it. It is produced, not given in advance; and its emergence is also the beginning of its erosion, as it brings about the cultural changes necessary to accommodate it. (64)

In other words, singularity itself needs to be thought of in terms of intersubjective experience, which reconstitutes our being in the world, relocating our place in relation to cultural memory and rearranging the contingencies of social life that bear on our conception of self as finite creatures. Far from being just enduring testaments to the material demise of human life, literary works bring home the reciprocal bond between human receptiveness of time and time's power to inscribe life with meaning. What this highlights in postmemory narratives is the agency granted to the reader as a repository of "the cultural ensemble by which he or she has been fashioned as a subject with assumptions, predispositions, and expectations" (Attridge 67). Considered in this line of thought, reading reaffirms itself 
as a practice of aesthetic apprehension and ethical vigilance correlative with the affective reciprocity that a particular creative engagement with the past calls for. Indeed, the epistemological distance inherent in postmemory literature makes the singularity of experience almost inevitable by virtue of the verbal communion between the living and the dead whereby the reader imaginatively reconfigures the past in the awareness of his or her own mortality. In Pogue Harrison's words, "To be mortal means to be the place of [an] imaginary afterlife" (149).

\section{Writing Deafness}

Insofar as contemporary historical fiction sets the stage for re-imagining past events, Deafening (2004) by Canadian author Frances Itani offers a compelling example of postmemory literature that grapples with the experience of the Great War. Organised around the life of its deaf protagonist Grania in the small town of Deseronto, Ontario, the fictional narrative aligns the story of a female coming-ofage with the story of "the birth of the Canadian nation within the historical narrative" (Teichler 240). As Hanna Teichler remarks in her essay on Joseph Boyden's novel Three Day Road, "Canada became fully independent in the aftermath of the Great War, due to its major successes on the battlefields, and entered the international stage as a 'worthy ally' and recognized nation. It was the moment when Canada could be regarded as a nation separate from Great Britain" (241). What links Deafening to Three Day Road, however, is not only their concern for the legacy of the Great War in Canada's mythology of nation building, but also their attentiveness to the historical experiences that have been largely omitted from the master narrative of Canadian history: the sacrifice and service of Indigenous people in Three Day Road and the moral endurance of the deaf in Deafening. In fact, Anna Branach-Kallas cogently argues that Itani's attentiveness to the experience of disabled bodies on the homefront marks an ethical shift in the representations of the impact of WWI, highlighting the concept of the periphery, which "acquires not only a geographical meaning (a small town in Canada), but a social one (a female perspective), and an ontological one (the point of view of a disabled person)" (129-130). Placing both Boyden's and Itani's novels, alongside Ondaatje's Anil's Ghost, Kerri Sakamoto's One Million Hearts, Camilla Gibb's Sweetness in the Belly, and Gil Courtemanche's A Sunday at the Pool in Kigali, within the context of their critique of Canada's contemporary discourse on security, Haike Härting and Smaro Kamboureli comment thus:

Concerned either with contemporary acts of civil war or the narrativization of hitherto marginalized experiences of the First and Second World Wars, these novels raise questions about the ideological and cultural function of narrating political or national identity formation through moments of a perceived national crisis, war, and heroic risk-taking. (674) 
Arguably, Härting and Kamboureli read this ethically and politically informed narrative perspective as suggestive of Canadian literature's critical response to Canada's identity as a peacekeeping nation. In fact, they point to the novels' power to unsettle "dominant legimitizing discourses of security" (676). Sokołowska-Paryż and Löschnigg, on the other hand, see it as endemic to the structure of contemporary postmemory narratives: "One can detect in post-memory literature and film a discernible need to include hitherto marginalized perspectives for reasons of race or gender, and restore the necessary prominence to unduly 'forgotten' Great War battlefields" (2). Inevitably, contemporary literary accounts of WWI are conceptually tethered to the current landscape of socio-political thought, which affects the discourse of commemoration and modes of imaginative "returns" that novels like Three Day Road or Deafening make possible.

One way to think about this is to remind ourselves of Hutcheon's notion of ex-centricity, through which she interpreted the ideological caveats of late twentieth-century historical fictions in English that highlighted the correlations between social divisions and institutional records of historical experience. Another is to consider Canadian historian Tim Cook's examination of the work of memory in Canadian historiography on the Great War. Cook observes that "Over the last hundred years, there appears to have emerged three dominant narratives on Canada's Great War, as played out in Canadian society, forged and remade with succeeding generations of participants, myth-makers, cultural creators, and historians" (417). The three dominant narratives postulate three modes of remembering that inscribe the Canadian experience of the Great War with collective meaning: "that of the war as a terrible and useless slaughter, the war as a nation-building event, and the war as a divisive event [...]" (Cook 417). Although the three interpretations do not shy away from acknowledging the different effects the war had on different fractions of Canadian society, in Cook's view, they consistently leave out the strand of memory of "the war as an absent event," which speaks of "the missing million males, aged eighteen to forty-five, who never enlisted for wartime service" (420). Seeing as this number does not include the young men who were turned down on medical grounds, there is still little known what motivated young Canadian men, beyond conscientious objection, to escape enlistment during WWI. For Cook, the question remains: "Did these men, all potential recruits, see themselves as soldiers of the soil and factory floor, or was the war simply an overseas event, to be followed in the daily papers with little inconvenience to oneself?" (421). As a master narrative of Canadian nationhood, the history of WWI is by no means lacking in mysteries and untold stories.

The collision of different, sometimes incompatible, memory threads in the archival fabric of the Great War finds a place in Deafening as well, what with the novel bringing together the war experience of a deaf woman in Canada and that of her hearing husband in the trenches of war-torn Europe. But Itani shifts the epistemological uncertainty and the ethos of narrative contingency that 
characterises so much of postmodern historiographic metafiction in favour of modes of sensual engagement with the past as evoked in deafness as a metaphor for postmemory. In this respect, the novel opens as a "sensual recollection of the past" (Trigg xviii), where it faces a double epistemological limit in its attempts to represent both past events and the experience of suffering. The deafness of the female protagonist furnishes the perceptual structure of the First World War as a sonorous event, inviting a correlation between our act of making sense and our reliance on the senses. Listening by way of deafness in Itani's novel emerges as a critical modality that rethinks the conceptual primacy traditionally attributed to vision, wherein deafness has been long considered not just a disability, but a form of intellectual defect or social deviance (Davis 2006, 6). In Deafening, by contrast, the deaf body operates as a hermeneutic agent, who is capable of grasping sense beyond sound and accommodating resonant meaning. If we accept philosopher Jean-Luc Nancy's reasoning that "All sonorous presence is thus made of a complex of returns [renvois] whose binding is the resonance or "sonance" of sound, an expression that one should hear - hear and listen to - as much from the side of sound itself, or of its emission, as from the side of its reception or its listening [...]" (16), then Itani's evoking of the Great War may be conceptualised along the lines of a poetics of resonance.

More precisely, the novel's figuration of deafness as a reflexive mode of historical experience shows its concern for how the past resounds in us, creating a moral premise for remembering through empathy and thus generating what Alison Landsberg calls "prosthetic memories": "privately felt public memories that develop after an encounter with a mass cultural representation of the past, when new images and ideas come into contact with a person's own archive of experience" (19). Guided by the idea of postmemory as sensual resonance, this reading of Itani's Deafening examines the narrative forms of sensual repercussions and emotional ricochets which underpin both the traumatic effect of the Great War on the novel's characters and the conceptual structure of sense as "the rebound of sound" (Nancy 30). As a consequence of thinking about meaning as "an arrangement of resonance" (Nancy 21), I suggest, the novel inaugurates a resonant subjectivity, which derives from the tensions of listening to the echo of the past, launching a singularity of sensual evocation where sense sounds and re-sounds in the act of reading as in a soundbox. In Deafening the subject of postmemory is not unlike the subject of listening, mobile in its singularity, "always still yet to come, spaced, traversed, and called by itself, sounded by itself [...]" (Nancy 21).

Given that Itani's novel conveys the war experience by alternating the points of view of Grania and her husband Jim, who joins the war as a stretcher-bearer, Branach-Kallas has reason to point out that the two perspectives "complete each other, creating an image of war as a "total" conflict" (128). Structurally, the novel consists of five parts, covering different stretches of time from 1903 to 1919, of which the first deals with Grania's life before the war, the second through fourth 
tell us how WWI affects Grania and Jim, and the last part ends with Jim's return from Europe to Canada. Grania's deafness is the epistemological ground on which Itani gives us access to the experience of war at the beginning of the twenty-first century: like her, we are physically distanced from the frontline (Grania remains in Canada) and limited in our understanding of the events themselves and their significance in history (like Grania, we read Jim's letters and the bodies of the wounded). The hermeneutic mastery associated with the novel's female protagonist makes us mindful of the extent to which we too depend on sign language, which writing is, partaking of the subjectivity of the deaf in the postmemory reception of the narrative resonance of the Great War.

As Deafening opens in 1902 with Grania's grandmother teaching her to pronounce her name, we learn that her deafness is a consequence of scarlet fever: "But her older brother, Bernard, calls her Grainy. Has done since the week she was born, and won't stop now just because the scarlet fever she had last winter made her deaf'" (Itani xiii). This episode, narrated in the form of a prologue and thus preceding the novel's first section, which covers the years 1903-1905, highlights Grania's silence as a moral corollary to the noise of the machine-gun fire, the frenzy of explosions, and the delirium of violence and death that follow in Jim's experience of the trench horror: "There is a terrible whispering in the night that never goes away. Sound is always worse in the dark" (209). In the novel's figural structure, too, Grania's survival of the scarlet fever links up with the devastating effect of the Spanish flu in Canada at the end of WWI, both forming a narrative frame that highlights the perceptual content of the war and the significance of the body as a corollary of memory and meaning. Itani's tropological emphasis on the body as a place of memory and a passage of resonance ties in with Casey's observation that the body is an epicentre of memory work beyond the agency of the mind. For the phenomenologist, body memory is "a privileged point of view from which other memorial points of view can be regarded and by which they can be illuminated" (Casey 148). This is particularly true of traumatic body memories, which "arise from and bear on one's own lived body in moments of duress" (Casey 154). In contrast to "habitual body memories" (Casey 151), which provide orientation and consistency in action, traumatic body memories heave into view "the fragmentation of the lived body" (Casey 155; original emphasis) that undermines its sustainability as a coordinated whole. To quote Casey at greater length:

This is the body as broken down into uncoordinated parts and thus as incapable of the type of continuous, spontaneous action undertaken by the intact body ("intact" thanks precisely to its habitualities, which serve to ensure efficacity and regularity). The fragmented body is inefficacious and irregular; indeed, its possibilities of free movement have become constricted precisely because of the trauma that has disrupted its spontaneous actions. (155) 
Within the context of Itani's novel the range of traumatic experiences to which the body is exposed foregrounds a conceptual link between disability as a consequence of a medical condition and disability as a result of war trauma, bringing to our attention the impact that dominant discourse on disability has had on remembering the Great War. By doing so it also brings forth the interconnections between processes of physical and psychological rehabilitation, moral recuperation, and sensual recollection that accompany the kinship between the human care for the body and care about cultural memory.

A number of scholars working in the field of disability studies (Davis 1995 and 2006; Garland Thomson 1997; Hall 2016, etc.) have aptly demonstrated that modern attitudes to deafness, which insist on treating it as a form of physical lack, often also an intellectual flaw and moral deficiency, emerged in the eighteenth century, with the reign of Enlightenment emphasising the virtue and authority of reason as made manifest in the competent use of language. Throughout the nineteenth century, however, attitudes to deafness as a disability kept in step with the rise of statistical work and the pseudo-scientific discipline of eugenics, both of which, as Lennard J. Davis reminds us, "bring into society the concept of a norm, particularly a normal body, and thus in effect create the concept of the disabled body" (6). It is with respect to the cultural construction of normalcy that literature, too, falls under the radar of critique, where disability theory highlights the reductive nature of "narrative prosthesis" in which "disability metaphors are used to aestheticise and depoliticise disability issues" (Hall 37). Davis, in particular, finds fault with the narrative structures inherent in the novel, which promote a hegemonic imperative of the human body and "reproduce, on some level, the semiologically normative signs surrounding the reader, that paradoxically help the reader to read those signs in the world as well as the text" (11). However, in Itani's literary universe, I would argue, the trope of deafness testifies to the novel's capacity to upset the conventional marginalisation of "extraordinary bodies" (Garland Thomson 7), which favours able-bodied citizenship, and transform the figurative power of "narrative prosthesis" (Hall 37) into "prosthetic memories" (Landsberg 19) and morally-binding empathy. Central to Itani's rethinking of our ethical relationship to the body is, on the one hand, her examination of the foil of social attitudes against which Grania constructs her subjectivity as a deaf woman, and, on the other, the novel's dismantling of the silence/sound dichotomy in conveying Jim's response to the war atrocities as the end of "normal" life. This is how, instead of a medical condition, deafness emerges as a critical modality, which gives access to the witnessing of social deformation that marked the reality of the Great War.

As a child, Grania does not perceive the silence, to which the scarlet fever relegated her, as a social handicap or intellectual impairment, something her grandmother emphasises by praising Grania's expert lip-reading: "You could read lips before you were deaf. When your parents wanted to talk - grownup talk - they had to turn their backs to whisper because you were so nosy. Do what you've 
always done. Before you were sick. You're the one in the family who sees" (Itani 8). Though elevating sight as a compensatory faculty, the grandmother nevertheless engages the whole of Grania's body as a participant in meaning-making: for example, the girl learns to "feel time" (12; original emphasis) by tracing her hand through "the pulse of the clock" (12) and differentiates between smells: "Father calls himself a wine merchant and sometimes he smells like wine, or damp fruit. His smells are different from everyone else's" (13). Grania's ocular, olfactory, and haptic engagement with the world enhances her body's capacity to feel "a density in depth" that Casey attributes to body memories by virtue of which the lived body not only moves through physical space, but also resides in "its own depth" (166). This is to say that in constructing Grania's subjectivity Itani conceptualises her deafness as intrinsically "depth-affording": her situatedness in the world calls for perspicuity that balances out the imperatives of "aspiring and anchoring," which characterise humans as "upright beings" (167). The sense of touch, however, is given a special significance in Deafening because it pertains to Grania's relationship to language as that which binds her simultaneously to herself and to others. For one, in teaching Grania to pronounce words, her grandmother explains them in tactile terms: "Mamo's palms press against her chest. Close. Keep the words close" (17; original emphasis). So much so that when Grania watches herself in the mirror, her physical attempts at articulation are compressed into a simile that calls attention to a sense of material separateness between herself and her voice: "She holds her voice as close to herself as she can. It is like pressing a pillow against her chest, the way the boy in the picture presses the book to his sailor suit. Grania keeps her voice close to the front of her body and makes it stay in that one held place" (17). To the extent that Grania watches her body produce and receive voice, she operates not unlike her own ventriloquist's dummy, an image that stands out in the insults thrusted upon her: "'Dummy!' the taller boy yells. 'Listen to her. She's a dummy!'” (Itani 23). Indeed, as Steven Connor powerfully argues in Dumbstruck - A Cultural History of Ventriloquism, voice situates us in front of ourselves by leaving ourselves behind: "As a kind of projection, the voice allows me to withdraw or retract myself. This can make my voice a persona, a mask, or sounding screen" $(2000,5)$. By drawing our attention to the arduousness of Grania's producing her voice, the novel foregrounds the significance of vocalisation in the construction of her subjectivity. Connor's reasoning here is unequivocal: "giving voice is the process which simultaneously produces articulate sound, and produces myself, as a self-producing being" $(2000,3)$. The material proximity of voice to the body as underlined by Grania's grandmother's teaching is in keeping with the aporia of voice as that which brings the speaker's world into being through simultaneous participation in the voice and parting with it. As Connor puts it,

My voice defines me because it draws me into coincidence with myself, accomplishes me in a way which goes beyond mere belonging, association, or instru- 
mental use. And yet my voice is also most essentially itself and my own in the ways in which it parts or passes from me. Nothing else about me defines me so intimately as my voice, precisely because there is no other feature of my self whose nature it is thus to move from me to the world, and to move me into the world. If my voice is mine because it comes from me, it can only be known as mine because it also goes from me. My voice is, literally, my way of taking leave of my senses. (7)

Unsurprisingly, it is Grania's senses that are put into question on account of her deafness and mispronunciation at school. When the other children warn her about the presence of a skunk on school territory, Grania cannot pronounce the word, succumbing to "weary speech": "She has slipped back. She has used what Mamo calls her "weary speech" but she doesn't care" (Itani 24). The adjectival modifier gestures back to the lived body, which mediates the phenomenological conditions of Grania's vocal presence. Crucially, she learns vocal projection from her experience of other lived bodies, particularly her grandmother's, which enable her to think of her own body as capable of meaningful sound beyond voice: "Grania walks along Main Street. It is late October, a sunny afternoon. She is wearing her white blouse and her navy skirt. Every time her foot presses down on a cedar board in the sidewalk, a trill enters her foot. Music, she thinks. My feet are making music" (Itani 49).

Anchored as it is in the material boundaries of the lived body, touch is the sense that modulates the secret language of rope tugs that Grania invents to communicate with her sister Tress before sleep: "She is one tug, Tress is two. She rolls on her side and stretches the rope until it is barely taut, just enough so that she can feel Tress at the other end. Now the rope name-signs are clear. Now the two create tug patterns, back and forth - patterns that are meaningless, that make them laugh silently to themselves in the dark" (20). Tethered to the materiality of the body, this language of signs perceptually differentiates Grania from other children at school, who go on teasing her about mispronouncing words:

"Say spit."

"Thpit."

"Ha Ha. You said thpit."

Grania makes the crazy sign at them, her cupped hand waggling beside her ear. (57)

When Grania is sent to a residential school for the deaf in Bellville, she learns that her instinct about the creative potential of hand communication has been right all along: "Along with Grania, there are eleven other children in the room. Eight of these know the sign language. They signal to one another with animation; they prance like mimes" (83). Although initially struggling to emotionally adjust to her new circumstances and master the sign language, eventually Grania learns to listen to her own body and connect to others: 
A language is taking shape, one in which, haltingly, she is beginning to take part. She misses and misunderstands, but puts meaning - right or wrong - to words that come at her in sign. Her hands, to her surprise, and jerkily at first, begin to send ideas out. Her face and body punctuate; her eyes receive. She is falling into, she is entering a new world. She is joining the larger conversation of hands. (84)

Itani foregrounds the body's capacity for connectivity and signification: what the signing hands do is translate human corporeality into an extended eardrum, vibrating in reciprocity to the world's presence. Far from being negatively defined by her deafness, Grania finds creative agency in her body, which hears and emits meaning through the material texture not limited to the ears. This is in keeping with Michel Serres' observation in The Five Senses that "We hear through our skin and feet. We hear through our skull, abdomen and thorax. We hear through our muscles, nerves and tendons" (141). In Deafening, though, hearing not only extends throughout the body, but also overlaps with body memory. When asked about what she remembers about losing her hearing, Grania's friend Fry answers in sign language: "I was sick - weeks in bed, not much remembering now. But I remember my heart pounding so hard I thought it would explode. First time I went outside, I felt my own footsteps walking through me. Like being trapped in a drum. I believed I was hearing" (Itani 92). For Itani, Grania and Fry's signing brings to light the sensual perimetre of the body as something like a soundbox or a tuning-fork, calling attention to the acoustic structure of memory in the affective economy of resonance.

What Fry hears may be approached in terms of what in Listening Nancy calls "the resonance of a return" (12), highlighting the phenomenological structure of hearing as a way of being in the world. In this conceptual framework, human subjectivity derives from the relation of resounding that connects human interiority to an acoustic source outside. Resonance, whereby sound travels through the body, awakens us to the formation of sense, which gives itself as sensing that binds a self to sound in the shared space of reference. To quote Nancy,

One can say, then, at least, that meaning and sound share the space of a referral, in which at the same time they refer to each other, and that, in a very general way, this space can be defined as the space of a self, a subject. A self is nothing other than a form or function of referral: a self is made of a relationship to self, or of a presence to self. (8; original emphasis)

Central to Nancy's conceptualisation of selfhood is the mobility of sense (both sentience and meaning), which rather than solidify our perception of a unified subjectivity, spreads it around, refusing any objectification of the self outside of its moving engagement with the world. Connor's reasoning about the dynamics of sound in organising our sense of self follows a similar line of thought: 
A person is a throughput, a sound-through, and a through-sound. You become a person through sound, the word seems to say, through the sound that passes through you, circulating between the three grammatical persons that every person comprises first, second, and third - pluralizing its singularity. We are persons because we are sonified, we are personifications of the sounds that we absorb and exude. Ego is echo, personhood is resonance, the resounding of the persona: "personance," held together by a sort of persistence of hearing equivalent to the cinematic persistence of vision. $(2011,37)$

Grania's own sense of self, then, is inseparable from her experience of sounds in deafness as well as her memories of the sounds she heard as a child. Her physical engagement with the acoustic form of English also has important implications for how she perceives herself as a subject. Words resonate in the depths of Grania's body and in reciprocating Fry's story, she signs that she remembers "Sounds. I think there are sounds in my head" (Itani 92). By bringing forth the body's ability to retain resonance, Itani challenges the view that the deaf live in the absence of sound, which prioritises acoustic language over sign language, and questions the system of values that endorses the dichotomy of sound vs. silence that underlies the dominant social attitudes towards deafness.

The joy Grania finds in becoming part of the community of sign language in Belleville is contrasted to her frustration over trying to control her voice in speaking. The teacher's, Miss Amos', technique is not very different from that of Grania's grandmother, both emphasising the material weight of language: "Feel the word. Now to my throat, back to my lips. Let the shape of the word fall into your fingers. Scoop it up with your hand" (87). The novel's reference to the social pressure to teach voice modulation to the deaf is reminiscent of the clash between the oralist and manualist culture in the education of the deaf in the nineteenth and early twentieth century. As Douglas Boyton explains, the orthodoxy of oralism, which remained in place in North American schools for the deaf until the 1970s, stemmed largely from the shift that had taken place in the social attitudes to deafness:

The meaning of deafness changed during the course of the nineteenth century for educators of the deaf, and the kind of education deaf people received changed along with it. Until the 1860 s, deafness was most often described as an affliction that isolated the individual from the Christian community. Its tragedy was that deaf people lived beyond the reach of the gospel. After the 1860s, deafness was redefined as a condition that isolated people from the national community. (Boyton in Davis 33)

Given the significance that is attributed to the ability to speak in Grania's world at the beginning of the twentieth century, it is not surprising that her mother spends a long time refusing to accept the fact of Grania's deafness and even has doubts about sending her to an educating facility for the deaf: "Mother has not made up her mind about schooling. Twice a week, she goes to the Catholic church and 
prays that Grania's hearing will come back. Even though the priest shakes his head, Mother has not given up hope" (Itani xiv). While Mother feels guilty about not having diagnosed the scarlet fever early enough to have prevented Grania's loss of hearing, her initial decision to school her daughter with the hearing children is also in line with the way her society lumps deafness and muteness together as coextensive categories of physical impairment. This is made especially evident in the title of the Bellville school, The Ontario Institution for the Deaf and Dumb, as well as the school newspaper, The Canadian Mute, both of which dispense with the reference to speech only during the outbreak of World War One. Cedric, a friend of Grania's and chief editor of the newspaper, we are told, brings to public attention the condescending implications of using "dumb" and "mute" in reference to the deaf: "'Dumb,' he once wrote, 'has the secondary meaning of dull, stupid, or doltish. The word mute brings forth the image of an attendant at a funeral"' (179; original emphasis). For Grania's mother, too, it takes the intrusion of the Great War to enable her to acknowledge the power of the sign language to express the fragility of emotion. She uses her hands to convey the joy of learning that Tress' husband, Kenan, is alive: "A-L-I-V-E. Not by air writing, not by printing. Mother, who had refused to acknowledge the sign language these many years, had used the single hand alphabet of the deaf and had finger spelled the word. Mother had sent a word to Grania in the language of hands" (268-269). In a subtle evocation of "narrative prosthesis," Itani dismisses the idea of voice as the ultimate source of self-extension, a prosthesis of self, and salutes the generosity of the body as a medium of sense.

Another way in which the novel measures the moral resonance of social attitudes to deafness is conveyed in the author's use of epigraphs, featuring excerpts from The Canadian, and fragments from letters, most of them written by deaf schoolchildren and scrupulously studied by Itani as part of her research into the crossovers between the education of the deaf at Bellville and the impact of the Great War on Canadian society. This is what the author says in her interview with Susan Fisher:

I set myself the task of reading the school newspapers printed at the school. I chose, in a more or less arbitrary way, the years $1900-1915$ as a starting point. The newspapers came out of the school print shop and contained material of enormous interest to me. What fascinated me the most was what the children themselves had written [...]. I could see that they were, in many ways, telling their own stories in a unique language and from a unique time. Their voices literally shouted to be heard. (50)

Deafening is by no means documentary realism, but the threads of non-fictional accounts throughout the novel give epistemological balance to the actions of fictional characters, who confront social myths about deafness in their daily life. A conspicuous example is a quote attributed to Alexander Graham Bell, which opens Chapter 4: "A number of years ago I visited a large school for the deaf, 
and taught all the pupils to use their voices. In a few cases the effect was decidedly unpleasant, the voice resembling somewhat the cry of a peacock" (Itani 77; original emphasis). Readers familiar with how Bell's ideas link up with the eugenicist ethos (Davis 2006, 7) may interpret the epigraph as an ideological scene which awaits every deaf child as he or she enters the residential school in Bellville in the novel. The confusion Fry experiences when trying to work out the correlations between pronunciation and meaning, we understand, haunts all deaf people submitted to the rigours of oralism: "When I can't find a word, I finger spell under the table like a little child. But some words still look the same to me. When I speak, I find out that the hearing say them differently. Wind and wind. Tear and tear. No wonder we get confused" (Itani 125; original emphasis).

Because Grania, unlike Fry or their friend Colin, who was born deaf, is adept at both lip-reading and voice control, she navigates between sound and silence in the Bellville school. For example, during her first weeks at school she recites her fears aloud before sleep to overcome her longing for her family: "Don't let me live here forever. / Don't let them lock the big doors. / Don't let me be an orphan. / Let me go home again" (91). Significantly, though, her chant affects her whole body, taking hold of the hands that bear the weight of both sound and silence: "She chants to herself, her fingertips tapping the side of her legs as she throws her fears out into the dark. She inches her body down into the bed and even deeper into the place where her silence lies, the place where she is safe" (91). In time, sign language becomes a mode of social interaction that Grania comes to embrace as her own, even at the displeasure of her teachers:

It is years later, after Grania learns to own the sign language by taking it inside herself - though the hearing teachers will eventually forbid its use while she struggles to please them with her voice - it is years later when she realizes how close to the visual-gestural language she and Tress actually were with the childhood signs they once invented for themselves. (96; original emphasis)

Giving preference to oralism as a means of finding a place for the deaf in national unity has its own repercussions in Deafening when Canada enters the Great War. The profound effect of the war on the deaf proves to be its divisive character, which separates the deaf from the rest of Canadian society not only as disabled bodies, but also as bodies subject to suspicion by virtue of the invisibility of their disability. Nowhere does it become more apparent than in Colin's persistent attempts to join up, at which point he is always told that "the army didn't need deaf boys" (118). Yet in the eyes of the larger public, who are ignorant of his deafness, Colin is a coward, something Fry relates to Grania in her letter and "Grania felt her own anger rise on his behalf, but she knew there was nothing she could do" (186). Grania's brother Bernard, who is barred from enlisting because of his lung condition, falls victim to a similar treatment when their neighbour's daughter pins 
him with a white feather as a sign of cowardice. Bernard feels humiliated, but is not vindictive towards the woman's ignorance: "She doesn't know anything about my lung, Grainy. There is no point explaining to her or anyone else" (252). His choice of silent endurance joins him in the ranks of the deaf in the novel, whose tenacity in the face of social ignorance and inexperience aligns with the moral fibre of the Canadian soldiers serving on the Western Front. In a twist of sad irony, the invisibility of the reason for which the deaf young men are not allowed to enlist in WWI brings to visual prominence in Deafening the agency of the able male bodies witnessing first-hand the harrowing violence of the trenches.

\section{Writing the Body at War}

Grania's husband Jim, a hearing young man, who joins the Canadian Army Medical Corps as a stretcher-bearer, is the novel's perceptual centre of the first-hand experience of WWI. In the narrative dichotomy of sound vs. silence he not only lives in sound, but, more importantly, arranges sound into song. His capacity for music is first foregrounded by reference to his hands when he learns that a son of a doctor with whom he works wants to be a gunner in the war: "At the word gunner, Jim looked down at his own hands. His grandmother, who had raised him, had taught him to play piano with those hands" (Itani 106). The implied opposition between a musical instrument and a gun, as extensions of human hands, becomes coterminous with the opposition between creation and destruction in the dynamics of sound and silence in Itani's novel. In Jim's courtship of Grania we recognise an isomorphism in his use of hands both for playing the piano and for the tactile language of love that binds their lives:

He did not need sheet music; he could play by ear. His grandmother had taught him the notes when he was a child, and he had learned to chord by himself. His long fingers looked as if they were floating across the keys. Grania had stood beside him and watched song come from his lips. She'd placed one hand on his shoulder and the other on the top panel of the piano. Her body had stilled as she'd allowed his music to enter her. (138)

Again, Itani places emphasis on the body's ability to store sound, so that the vibrations emanating from Jim's hands not only enter Grania's body, but also maintain their presence as an ontological resonance of feeling, to the extent that Jim's producing music may be interpreted as a metaphor for making love. The sound of music assumes the character of manual movement, thus allowing Jim to touch Grania from a distance, by dint of the resounding of his persona. Hands, we understand, bind one body to another, both in sound and silence: "Jim's message was always music. Her tapped words were a kind of music, too. Music for the upset or alone" (145). In other words, Itani invites us to think about music as analogous 
to sign language, where the body conveys meaning by way of sensorial engagement, an act that is literalised in Grania's engagement to Jim before he goes to war.

Jim's musical deftness and Grania's deafness coalesce in the sensuality of touch as evoked by musical performance:

Jim reached across in the dark and lifted her hand towards him. He traced a fingertip around the edges of her palm for several moments and she sat, motionless, scarcely breathing. She was afraid she would make a noise with her throat. They were surrounded by people on both sides, in front and behind. In that crowded place, every seat taken, Jim rested the back of her hand against one of his, and with the other he silently placed a word in her palm. She felt the flush in her cheeks. She did not see the scene change, not until the lights became brighter and the colonel stood on the stage to give the address. (143)

If we accept Serres' contention that touching "is situated between, the skin is the place where exchanges are made, the body traces the knotted, bound, folded, complex path, between the things to be known" (80), then this scene, too, may be read along the lines of metaphorical love-making. In "placing" a word into Grania's hand, Jim intimates his knowledge of the body as a medium of sensual heat, which reverberates in the young woman's cheeks and her stifled cry of joy. For, as Serres notes, "Skin translates the amorous caress into arousal, subtly displaying desire and diluting listening and seeing to the point where they almost disappear" (71). At the same time, also, for us, this act reconnects to Grania's own relation to acoustic language conceptualised in tactile terms. Like Grania in her childhood, Jim materialises language as a tactile gesture that inscribes human tissue with a quiet strength to connect and communicate sense. A steward of the senses, the body participates in constructing a shared sense of human experience of the sensual and sensible world. As Serres reminds us, "The skin receives the deposit of our memories and stocks the experiences printed on it. It is the bank of our impressions and the geodesic panorama of our frailties" (75).

The erotic dimension of corporeal life in Deafening unfolds in dramatic opposition to the narrative of war as a technology of the body. Early on, the beat of the drums in the station from which Jim departs to Europe anticipates the effect of the noise that pervades the trenches. As Grania accompanies Jim to the train station, her body is invaded by the sound of the drums: "[...] Grania's body began to clench, a knot working its way inside. The band that had marched to the station platform continued to play and she felt the beat of the drums inside her" (149). In the unfolding of emotional resonance Jim responds through their shared language of hands: "He took her hand and held it firmly inside his own and she felt only the pressure of his skin on hers. Don't let go. The war is close. The war is closing in" (149; original emphasis). Where love enables Grania and Jim to overcome the split between language and experience as well as hearing 
and deafness, the war, which separates them both geographically and phenomenologically, exacerbates the inadequacy of the verbal medium which brings to light the witnessing of injury both characters go through.

Although initially Jim is eager to see "Mother England" (158) and fearful of not "getting to France in time to see action" (160), the harrowing reality of the trenches soon disabuses him of any illusions about the war he may have had. In contrast to the quiet strength of his life in Canada, the war assaults Jim's senses in the form of ubiquitous noise. In one of his letters to Grania he writes: "Sometimes, I hear a sound like thunder. How can I describe this sound? An invasion in the dark, a pulse that grows in the head. It starts as a level throb and, after that, it weaves its way like a thread through every nerve in my body" (163). Jim's perception of the overload of sound speaks of the power of warfare to disseminate itself acoustically by invading and incubating human subjectivity and subjecting it to gradual disintegration. For as Connor notes, "if sound suggests the idea of the exercise of power, this may be because it more fundamentally involves the subjection to it" $(2000,26)$. Jim ends his letter by signing "Chim," visually literalising Grania's voice as she pronounces her husband's name. In the reciprocal structure of listening, this verbal signifier shows how Jim's testament of love derives from the resonance Grania's presence has in his selfhood. If we agree with Nancy that "listening is passing over to the register of presence to self" (12), then the body memory of his wife's quietness, which enables him to hear himself, reveals itself as the key premise of Jim's survival through the insanity of the Great War. So much so that Jim's search for silence in the trenches aligns with Grania's concentrated attention from across the ocean: "The more she is able to focus, the farther her silence extends, spreading slow and even, like moonlight over water" (Itani 197). Understandably, then, Jim's relation to the suffering he witnesses is phenomenologically bound to the silent vigilance he associates with Grania:

He wonders what it would be like to shut his ears to sound - knowing that sound will enter him anyway, through his body. He is bloody and dirty and his eyelids are encased with soot and he forces them to close, and a silence - perhaps it is Grania's silence, having searched and found - encompasses, creates a different sort of shelter, one that fits the contours of his lean young body and makes it safe. (200)

Jim's resorting to silence eventually becomes a mode of accommodating himself to the destructive agency of the Great War. The longer he stays in the trenches, the more he longs for the sensual equilibrium he shares with Grania: "If it were dark, she would place her fingertips over his lips and she would gather his words into the place of their shared understanding" (205). Serres may have put it best: "Immersing yourself in silence is a form of healing; solitude releases silence from the control of language" (88). 
Jim's longing for Grania's silent language of touch is opposed to the debilitating effect of the noise that constitutes war. The sensual joys of haptic experience aligns with Casey's reminder about the body as a source of memory: "The bodily remembered touch is intrinsically pleasure-giving: the pleasure does not follow the experience but belongs to it as ingredient in it" (158; original emphasis). By contrast, the noise on the front is inherently traumatic as a result of the warfare metonymically distending itself through auditory means of hostile engagement. Itani calls our attention to how the body hears in spite of itself: "At times, the ground shudders beneath our boots. The air vibrates. Sometimes there is a whistling noise before an explosion. And then, all is silent" (Itani 285). In the middle of such devastating explosion Jim is seized of the significance of gestures that the medical officers employ to save the injured survivors: "Even so, the M.O. was motioning again with his hand. Sign language" (174; original emphasis). In an act reminiscent of Casey's observations about the fragmentation of the lived body evoked through traumatic memories, Jim's own hands respond in convulsive spasms to the pain-inducing noise that pounds in his ears: "His ears were tunnelled with pain, and he looked down at his hands and saw his own long fingers flexing rapidly as if conducting themselves through a bizarre set of exercises" (175). It is the image of the hands, in fact, that haunts Jim the most, amplifying his distress at his inability to save young men from dying: "If only he did not have to look at the hands. In death they told more than the face; he knew that now. It was the hands that revealed the final argument: clenched in anger, relaxed in acquiescence, seized in a posture of surprise or forgiveness, or taken unaware" (204). Metonymic splinters of lived bodies, the hands of the dead speak of lost human agency in the world, but for Jim, more importantly, they are a reminder of Grania's hands and the promise of life they embody. In one of his letters he confesses to have finally understood her deafness as a hermeneutic:

One day you told me - we were sitting on the blue blanket - you told me about the way understanding for you is sometimes delayed. I know more about that now. More about the gap between what happens and what is understood. What is there and what is not. So much tries to make entry; so much is determined to invade. Sound knocks us over, blocks all thought, seeps into the body like deadly gas, seeps into everything around until there is no rift or fissure left unfilled. (260)

The war is shown to magnify the rift between our bodily experience of events and the meaning we ascribe to them. Jim's rumination on noise highlights the fractures in human structures of perception where sound gains toxic agency at the expense of human sentience and finally transforms human subjects into nothing more than vibrating material tissues. Itani's use of simile and prosopopoeia in describing the force of war sounds remaps the war itself as a process that turns abstract phenomena into agency and human subjectivity into thingness. The Great War in Deafening animates itself at the expense of human selfhood and 
human life. This is why the image of human hands, a medium of world-making that preoccupies Jim's memory, reveals the extent to which the human world becomes unmade during the war. At the same time, the act of dismemberment that the image of hands as "testimonial objects" (Hirsch 24) evokes pertains to the novel's concern for the acts of transfer in postmemory contexts that Itani's readers inhabit. Material testimonies to the war trauma, the hands of the dead "thematize the act of holding - caring, protective, and nurturing" (Hirsch 99), associated as they are with embodied modes of knowledge that call for responsiveness and responsibility in recollection.

The ways to remember the Great War that Itani's Deafening hands down to us emphasise the tumultuous force pervading the trenches, which figures as a sourceless acoustic impact that annihilates, mutilates, and disfigures able bodies:

Men who have passed here before them have picked some of the bodies and tossed them over the side so they could get through themselves, and the ground is covered with more of the dead. The soldier they are carrying now has been shot through the face; half the face is gone; it is just missing. A terrible sound is coming from the place below the hole where his lips and mouth should be. (198)

In the novel's figural terms, on the frontline, the whole body seems to change into an extended eardrum, resonating, palpitating, and bursting with the noise that fractures the sense of self and sends soldiers into a state of shell shock. Jim gives an account of witnessing a young soldier suffering from this condition:

The boy's body was shaking; his head was twitching and his eyes rolling around without focus. His arms and hands and legs and feet had to be propped between the boys before they could drag him to a bed. This is a terrible sight that affects everyone. It is like watching a convulsion that never ends. (216)

The scene conveyed is not unlike a spectacle in which we observe the directorial activity of death, with soldiers as mere stage props or ventriloquist's dummies. The disintegrating body of the young soldier substantiates the spirit of slaughter that operates the novel's machinery of the Great War. By bringing our attention to his uncoordinated limbs, the narrative shows how his body communicates his broken sense of self: not only has he become a contracting mass of body parts, but his consciousness, too, has shrunk to a space of delirium, where "the only word he could get out was Mother" (216).

What is crucial to the novel's attentiveness to the suffering body is its recognition of the impossible task that the experience of pain poses to verbal representation. Jim's sense of the failure of language is conveyed through free indirect discourse, which brings forth the disconnectedness between what Jim went through, what he remembers, and what he can tell Grania: 
He wanted to tell her how sorry he was that he'd left. He had been so hopeful, so filled with desire to help in the war. He wanted to do his bit like everyone else. But no one at home could have any idea of what this stretch of earth in the Salient now contained: scar, and death, and the memory of impossible acts. The terrible thing was that no one at home would ever know. Because what was happening was impossible to be told. (205-206)

In conceptual terms, it is worth recalling Elaine Scarry's observations in her book The Body in Pain about the juxtaposition of the body and voice in the structure of war:

The essential structure of war, its juxtaposition of the extreme facts of the body and voice, resides in the relation between its own largest parts, the relation between the collective casualties that occur within war, and verbal issues (freedom, national sovereignty, the right to a disputed ground, the extra-territorial authority of a particular ideology) that stand outside war, that are there before the act of war begins and after it ends, that are understood by warring populations as the motive and justification and will again be recognized after the war as the thing substantiated or (if one is on the losing side) not substantiated by war's activity. (63; original emphasis)

In Scarry's reading, the tension between discourse and the body inherent in the structure of war is coextensive with the loss of agency in the experience of suffering. Because pain deploys the body as an agent of agony, it warps its perception of the world, depriving the suffering subject of the ability to verbalise the content of pain: "Intense pain is also language-destroying: as the content of one's world disintegrates, so the content of one's language disintegrates; as the self disintegrates, so that which would express and project the self is robbed of its source and its subject" (Scarry 35). The body itself, rather than voice, becomes the material sign that substantiates the ideas for which the war was fought and human agency was handicapped

In this respect, the death that sweeps through the war trenches of Europe finds an analogue in the effect of the Spanish flu in Canada. Grania is one of the people in Deseronto to succumb to this deadly illness. Here Itani is mindful of how the body knows and communicates ailment in advance of the consciousness' grasp of meaning: "Grania now looked at her reflection in the oval mirror and tried to steady herself. There were shadows under the eyes that stared back. Her skin was pale, and she wondered why she hadn't noticed this the day before" (Itani 318). When she goes out for a walk, a raw pain attacks her from within: "A rawness scraped at her throat, and pain dug into her chest like a spade" (320). Eventually Grania's legs give and she collapses to the ground:

She felt a gurgling sensation on one side of her chest, and in disbelief she lifted a hand and pressed it beneath her left breast. At the same time, she said, Bubbles. How can there be bubbles in my chest? Fluid tilted up and over her tongue and spilled onto her hand, which was now bright red. She tried to pull forward the last 
few feet but sank to the earth, face down. Air moved in and out, past the gurgling in her mouth. (324; original emphasis)

In the novel's figural system, the image of the blood oozing from Grania's lungs aligns with the sight of bleeding bodies in Jim's care, amplifying the emotional resonance that the novel generates in the form of "prosthetic memories" (Landsberg 19) for the postmemory generation of readers. The analogies the novel draws between the lived experience of soldiers and the female protagonist on the homefront testify not only to the "profound transformations of a society which will have to confront the various disabilities of the homecoming veterans" (BranachKallas 131), but also to the memory work the narrative performs by negotiating the conceptual tensions between its figural, ethical and, epistemological terms. Itani's narrative engagement with historical suffering is emotionally enabling: to the extent that the deaf person may stand for the reader in print culture (Davis 1995, 113), the novel promotes empathy for Grania and, by extension, the characters she cares about.

\section{Writing Postmemory as Empathy}

The dynamics of empathy in Deafening correlates with the work of memory in the clash between body and language. Where the war enables "the eventual disowning of the injury so that its attributes can be transferred elsewhere" (Scarry 64), Itani brings us back to the human body as "the original site of the wound" (Scarry 64). By doing so the novel dismantles the structure of the war and repatriates the sensual dimension of injury, thus reclaiming subjectivity for the soldiers and refiguring the body as a material source of postmemory and emotional understanding. This is especially evident in the parallels between Jim's experience of losing his best friend Irish and Grania's gradual recovery from the Spanish flu, whereupon she learns about the death of her grandmother. In both instances the body is given the properties of a soundbox, in which experience reverberates, listening to its own inability to comprehend and communicate. Irish disappears in the midst of a sudden explosion while he and Jim are carrying a wounded soldier on a stretcher: "There was a shout. It was Irish. And a sudden sound that forced Jim to close his eyes - only for an instant - and then there was a whoosh, a rushing sound, and something louder, an explosion that rocked him forward and sent him flying off both feet" (Itani 330) The destructive effect of the blast shoots through Jim's body in the form of a shock wave, fragmenting his body into metonymic signs: "He tried to get up; his body was in tremors; his spine was hunched and would not or could not straighten. The shock had entered him as a physical blow, and it vibrated his chest until he believed his heart would explode" (330). 
Grania's sick body, too, is conceived as a receptacle of sound: "Thunder, in her body" (333). When she wakes up from a long slumber, she can hardly remember what happened and tries to fall back on her senses: "Sometimes a shadow sat in Mamo's chair; sometimes the chair was empty. Someone rocked, or the chair tipped back and forth by itself. There was a faint scent of Canada Bouquet" (337). For both Grania and Jim, the suspension of sight in favour of the other senses requalifies their bodily experience as an ambiguous agent of memory, magnifying the power of imagination to contribute to understanding. This may explain why Grania's memory erases the boundary between experience and reverie, allowing her to remember her brush with death as a situation in which she and Jim try to save each other:

Someone was reaching for her, pulling her up, and she clung to the bank, half in and half out of water. When she looked back she saw that Jim's legs, body and shoulders had disappeared. His face, above water, showed confusion, helplessness. He scrambled to get a finger-hold in drifting ice and pulled himself forward and tried to flip his body up and over the edge. He tried again. Grania, now safe on the bank, willed him to her side. She willed him to safety. (338)

Whatever its epistemological limitations, though, the body retains its memory in spite of the crisis of cognitive and linguistic agency. As Casey reminds us, body memory is "the natural center of any sensitive account of remembering" (148). For one, the body's ability to remember in the novel attunes it to the motility of war itself. Here too the use of free indirect discourse highlights how disconnected Jim feels from his body as an agent of experience: "The body remembered slick and treacherous footing, shallow trenches, the danger of Blighty Bridge, mats and duckboards laid over the worst places, ooze seeping through the cracks. The body remembered the lurch and roll of the dead. Feet and legs had memories of their own" (205). Even though it is Jim who is the focaliser, the substitution of his name by a generic noun suggests that his body memory has been shared through trauma in a way that the memory itself has become communal, turning all bodies of soldiers into an object of assault and subject of recuperation. In the machinery of combat in Deafening, the body of the soldier operates in the capacity of a mnemonic device which produces war as narrative: "A sort of memory machine installed in the body: sturdy coordinated parts, well-oiled arms and hands and legs and feet" (205). None more prominently, perhaps, than the injured body of Tress's husband, Kenan, who returns home alive, but with severe facial disfigurement and a phantom limb syndrome.

Having suffered a terrible head trauma, Kenan is sent back to Canada, but once safe at home he retreats into isolation, refusing to socialise with members of his community: "Kenan was speaking well, but he had not walked out of his own house [...]. Kenan never came to the door himself, never allowed himself to be seen" (300). Grania is the only one who finds access to his damaged self and we see Kenan's injuries through her eyes: 
What Grania was seeing was that Kenan's face was beautiful, as it had always been. Only now it was beautiful and terrible at the same time. He did not flinch under her inspection, and she was inspecting, looking into the ripple of scars, the obliterated eye, the deep folds on a surface that had once been smooth skin. No one else looks at his face, she thought. He doesn't give anyone a chance. (305; original emphasis)

What Kenan's mutilated face wears is a material record of the trenches, which separates him from his family and friends by virtue of pain's power to deprive man of language. His silence is tied to the agonising spasms he feels in the dead arm: "It had become apparent, too, that he suffered terrible pain, especially in his hand. The pain in the dead hand seemed, at times, to be unbearable. During the day, the hand was shoved deep into his pocket to keep the arm from swinging uselessly from room to room in the house" (287). In fact, Kenan's wounded body itself has become a metaphorical site of war: "His arm swings like a missile," Tress said. "The dead arm hits. He has no control over it" (286). In trauma, memory is shown to receive agency from the body by bending human subjectivity to its will. The weight of the metaphor that highlights the interchangeability of Kenan's arm and the gun he carried - "the iron weight of the arm he left behind" (287) - is such that it reveals the extent to which the war has robbed Kenan of his agency as a human being. As Scarry has noted, "War is relentless in taking for its own interior content the interior content of the wounded and open human body" (81).

The narrative's emphasis on bodily injury is crucial: the logic of metaphorisation here is at loggerheads with the principle of metonymy, thereby revealing the way in which relations of contiguity, which grant parts of the body the power to act in the capacity of the whole body, are sidelined in favour of relations of substitution, which divest the body of its agency and delegate fragments of the flesh to act in the capacity of an abstract force. In Kenan's case, the overriding of metonymy by metaphor in configuring his embodied consciousness helps to convey the crippling sense of alienation that Kenan feels with regard to his community, to say nothing of his own self. This may explain why he feels most comfortable with Grania, whose deafness stands in kinship to his own disability and whose stories about the community he has been absent from pave a way for the resurfacing of his own memories of trench horror. What haunts Kenan the most, we learn with Grania, is the memory of nearly dying at the hands of his own sentry, after having forgotten the password during a bombardment: "I could barely see. I said, 'Don't shoot me,' but I couldn't think what I was supposed to say. I knew then that I was going to pass out. I couldn't think of anything except, Get past this man, Get past this stranger" (Itani 306; original emphasis). Ironically, the word that saves him is the sound Grania used to make when they played in a dugout as children: "I heard my throat make - my mouth was full of blood - I heard my throat make the sound Wooms. Your sound, Grania. Our old password" (306; original emphasis). 
Like Jim's, Kenan's experience of war is conveyed in terms of a perceptual collision of the senses:

We'd been sent out on a trench raid. But shells started bursting around us and we scattered and I was hit. I lost my way and came back at the wrong point, and I stumbled into the post $[\ldots]$ it was after midnight $[\ldots]$ it was so dark. So much noise. There was no silence in that place. The boys went mad from the sound. Some tried to dig their own graves. (305)

The disorientation, which results from the fraught relation between sight and hearing during the explosion, highlights the vulnerability of the human body to the onslaught of violence. Again, Itani calls our attention to the menacing presence of sound as it invades and inhabits human interiority, sometimes to the extent of causing insanity. Overwhelming, all-pervading, and sourceless, the noise latches itself to all orifices, transforming human bodies into loudspeakers to be appropriated by the parasitical voice of the war. The paradox of the soldier's subjectivity is that by hosting the parasitical agency of the war in his body, he turns into a metaphorical parasite himself. Destruction and self-destruction on the battlefront go hand in hand. If we agree with Connor that "Sound, especially sourceless, autonomous, or excessive sound will be experienced both as lack and an excess" $(2000,23)$, then this aporia may help us understand Kenan's agony as well: his memories of the trenches are both lacking in and excessive of meaning that could anchor him in the present. This syncs with Trotter's observations about the significance attributed to noise in the British war novel: "Noise, especially loud noise, is always "agonistic": it involves the maximum at once of arousal and of passivity. The sound of the guns, composite and sourceless, was a primary terror for the soldier in the trenches" (Trotter 38). In this regard, Kenan's reluctance to expose himself to sight and hearing in Deseronto speaks of his uncertainty about being able to bring his first-hand experience of the Great War back in league with the experience of the people who stayed in Canada. He is torn between lack and excess in the circuit of memories and sense-making.

The capacity to communicate war experience to those absent from the sites of combat is crucial to the ethics of memory in Deafening. Itani measures the narrative power to elicit emotional response by appealing to the materiality of the body as a historical medium. In postmemory literature such engagement with the past realigns the relation between memory and empathy, inviting us to think about literature's aptitude for creating "prosthetic memories," which, as Landsberg maintains, demonstrate "the possibility that memory might be able to overcome biological logic" (35). For Landsberg, the advancement of technologies in transnational global capitalism has created "an emergent commodified mass culture capable of widely disseminating images and narratives about the past," where memories need not be "natural" or "authentic" and yet "organize and energize the bodies and subjectivities that take them on" (26). At the heart of this structure 
of remembrance lies the imperative to empathise, which, in Landsberg's reasoning, underlies the moral resonance of "prosthetic memories":

Prosthetic memories $[\ldots]$ have a unique ability to generate empathy. Unlike sympathy, empathy does not depend on a "natural" affinity, on some kind of essential underlying connection between two subjects. Empathy recognizes the alterity of identification and the necessity of negotiating distances and is therefore essential to any ethical relation to the other. (24)

In Deafening's economy of postmemory, too, there is an implicit recognition that the experience of others can be shared by way of sensual appropriation. Towards the end of the war, when Grania and Tress visit Toronto, they are reminded of a museum exhibition, which "included a mock night attack on the dugouts of the Hun" (Itani, 311). With Jim still overseas, Grania opts out of the visit: "Nor does she want to see blood-stained trousers that reveal the exact place a man's leg was torn off" (311). The epigraph that precedes this chapter in the novel quotes from a letter published in The Canadian that suggests what Grania may have missed out on:

In the glass case I saw the blood on the Prussian soldier's overcoat, and on the British soldier's cap which had been struck by shrapnel. I saw a pair of Belgian trousers which were torn away by a shell. I think the Belgian who wore them lost his leg. I liked to see the wonderful things from the great war. (307; original emphasis)

What the extract testifies to here, however, are the limitations, rather than infinite potential, of sight in bringing memory and empathy together. The viewing and writing agent in the letter has allowed sight to disconnect the material signs of the atrocities of war from their content, converting the work of death into a display of "wonderful things" rather than "testimonial objects" (Hirsch 24). Metonymic extensions of the bodies that wore them, the bloodied cap, overcoat, and trousers excite the eye, but fail to resonate in the depths of human interiority that relays the meaningfulness of the past.

Given the significance of resonance as a metaphor for postmemory in Deafening, it may not be surprising that the novel thinks of empathy along the same lines. Much like Jim, who learns in the trenches the nuances of Grania's experience of sound and silence, Grania herself is shown to rely on Jim's letters as a source of emotional resonance. Upon receiving a handkerchief in one of his letters, for example, she "raised the silk and pressed it to the soft spot below her ribcage, the spot at the centre. The place of the onset of breath before it becomes song. She held it there and did not move" (257). A metaphor for Jim's love as much as a metonymic sign of the proximity of his body, the handkerchief acts as a material conduit of emotion, which finds reciprocity in Grania's own embodied presence. When at the end of the novel Jim finally returns home, his body replaces the material 
substitute, bringing forth the moral resonance of memories condensed into one word: “'Sorrow,' his lips said then" (378). As an emotional modality of prosthetic memory, for us, sorrow encapsulates the novel's trust in the body's capacity to endure and nurture the complex of meanings the past produces. Grania responds to Jim by evoking the capacity of the body to simultaneously carry and create memories: "Sorrow can be borne" (378; original emphasis). It seems fair to say that, for Itani, this remains a moral imperative for the present age of postmemory.

\section{Conclusion}

The acoustic residues of the past, which appeal to the reader's ear in Deafening, tie in with "the desire to experience or reexperience history, not to validate the past without question, but to put into play the vital, indigestible material of history, reminding us of the uninevitability of the present tense" (Landsberg 47). In highlighting the body's capacity to both store sensual memory and take on "prosthetic memories" (Landsberg 19), Itani attends to the implicit prosthetic relationship between language, memory, and lived experience, as made manifest in the narrative construction of deafness and war trauma. While "giving voice to agents that have been silenced and marginalised because of such factors as geographical location, gender or disability," Deafening expands "the notion of total war" (Branach-Kallas 131; original emphasis) engulfing Europe and beyond. Arguably, this sense of totality derives from the tropological powers invested in the figuring of sound through the oscillating use of prosopopoeia, personification, and metaphor, which manifest the Great War as panophonic presence. The dominant metaphor of noise, in particular, heaves into view the significance of the body as a phenomenological premise of war experience, showing how the acoustic friction of ontological transformations demotes human agency at the rate of the growing powers of violence conveyed through the idea of resonance. Itani writes against the abstraction of war terror: the Great War hijacks the human body, not only subjecting it to exterior torment, but also invading its interiority, ultimately divesting it of qualities that characterise a man as more than a thing. Conceived as a figurative soundbox, the disabled and traumatised body in Deafening is haunted by the sonorous presence of war long after the military conflict has ended.

In this respect, the poetics of resonance in Deafening suggests that the construction of the past is homologous with the construction of subjectivity, for as Nancy reminds us, "Resonance is at once that of a body that is sonorous for itself and resonance of sonority in a listening body that, itself, resounds as it listens" (40). The figural pattern of poetic borrowings and substitutions that characterises both the mechanics and aesthetics of war in Deafening embed the structure of resonance in the moral economy of human life, where our understanding of war narratives inevitably calls for a critical rethinking of human complicity in 
historical agency. Insofar as Itani writes for generations distanced in time from the memory of WWI, resonance here moves in step with the imperatives of emotional reconnection and critical reflexivity in the narrative frame of postmemory. Itani's hermeneutic trust in postmemory takes root in the body's capacity not only to remember - often in excess of what the mind may allow - but also to extend itself, and thus its memory, through the practice of voice as a means of making sense through resonance. If we accept Connor's view that voice "actively procures space for itself' $(2000,12)$, then the voice of the past in Deafening conceives of its readers not unlike of "vocalic space" $(2000,12)$ to be inhabited and attuned like a soundbox. Ultimately, it is because resonance is aporetic in its constitution, being both disabling and enabling, both of the dead and of the living, that it binds the present to the past and the hollowness of forgetting to the depth of memory. For Itani, much like the listening subject attains its selfhood by the relay of resonance that ties human interiority to the exterior source of sound, so the present defines itself by listening to itself listen to the past in the hermeneutic act of remembrance. For readers of Deafening, especially, resonant subjectivity is a moral corollary of empathy that positions them in "the order of the posthumous image" (Pogue Harrison 149) in the age of postmemory.

\section{References}

Attridge, Derek. 2005. The Singularity of Literature. New York and London: Routledge.

Atwood, Margaret. 2002. The Blind Assassin. London: Virago.

Boyden, Joseph. 2005. Three Day Road. Toronto: Penguin Books.

Branach-Kallas, Anna. 2018. "Sharing Grief: Local and Peripheral Dimensions of the Great War in Contemporary French, British and Canadian Literature." Personal Narratives, Peripheral Theatres: Essays on the Great War (1914-18). Ed. Anthony Barker, Maria Eugénia Pereira, Maria Teresa Cortez, Paolo Alexandre Pereira, and Otilia Martins. Cham: Springer. 121-131.

Casey, Edward S. 2000. Remembering. A Phenomenological Study. Second Edition.

Bloomington and Indianapolis: Indiana University Press.

Connor, Steven. 2000. Dumbstruck - A Cultural History of Ventriloquism. Oxford: Oxford University Press.

- 2011. "Personifikationen/Personifications."Ars Viva 2011-12: Sprache/Language. Ed. Erik Bünger, Philipp Goldbach, and Jeurgen Stach. Berlin: Kulturkreis der deutschen Wirtschaft. 34-47.

Cook, Tim. 2014. "Battles of the Imagined Past: Canada's Great War and Memory." The Canadian Historical Review 95. 3: 417-426.

Courtemanche, Gil. 2004. A Sunday at the Pool in Kigali. New York: Vintage Books. 
Davis, Lennard J., ed. 2006. The Disability Studies Reader. London and New York: Routledge.

Davis, Lennard. J. 1995. Enforcing Normalcy. Disability, Deafness, and the Body. London and New York: Verso.

Fisher, Susan. 2004. "Hear, Overhear, Observe, Remember. A Dialogue with Frances Itani." Canadian Literature 183: 40-56.

Gadamer, Hans-Georg. 2012. Truth and Method. New York and London: Continuum. Garland Thomson, Rosemarie. 1997. Extraordinary Bodies. Figuring Physical Disability in American Culture and Literature. New York: Columbia University Press.

Gibb, Camilla. 2007. Sweetness in the Belly. London: Penguin Books.

Hall, Alice. 2016. Literature and Disability. London and New York: Routledge.

Härting, Heike and Smaro Kamboureli. 2009. "Introduction: Discourses of Security,

Peacekeeping Narratives, and the Cultural Imagination in Canada." University of Toronto Quarterly 78. 2: 659-686.

Hirsch, Marianne. 2012. The Generation of Postmemory. Writing and Visual Culture After the Holocaust. New York: Columbia University Press.

Hutcheon, Linda. 2003. A Poetics of Postmodernism. History, Theory, Fiction. London and New York: Routledge.

Itani, Frances. 2004. Deafening. Toronto: Harper Collins.

Landsberg, Alison. 2004. Prosthetic Memory. The Transformation of American Remembrance in the Age of Mass Culture. New York: Columbia University Press.

Lyotard, Jean-François. 1984. The Postmodern Condition: A Report on Knowledge. Manchester: Manchester University Press.

Nancy, Jean-Luc. 2007. Listening. New York: Fordham University Press.

Ondaatje, Michael. 1993. The English Patient. New York: Vintage Books.

—. 2001. Anil's Ghost. New York: Vintage Books.

Pogue Harrison, Robert. 2003. The Dominion of the Dead. Chicago and London: The University of Chicago Press.

Rushdie, Salman. 1993. Midnight's Children. London: Jonathan Cape

Sakamoto, Kerri. 2004. One Million Hearts. Toronto: Vintage Canada.

Scarry, Elaine. 1985. The Body in Pain. The Making and Unmaking of the World. New York and Oxford: Oxford University Press.

Serres, Michel. 2008. The Five Senses. A Philosophy of Mingled Bodies. London and New York: Continuum.

Sherry, Vincent., ed. 2005. The Cambridge Companion to the Literature of the First World War. Cambridge: Cambridge University Press.

Sokołowska-Paryż, Marzena and Martin Löschnigg., ed. 2014. The Great War in Post-Memory Literature and Film. Berlin and Boston: De Gruyter.

Swan, Susan. 1983. The Biggest Modern Woman of the World. Toronto: Lester and Orpen Dennys Publishers. 
Teichler, Hanna. “Joseph Boyden's Three Day Road: Transcultural (Post-)Memory and Identity in Canadian World War I Fiction." The Great War in Post-Memory Literature and Film. Ed. Martin Löschnigg and Marzena Sokołowska-Paryż. Berlin and Boston: De Gruyter. 239-253.

Trigg, Dylan. 2012. The Memory of Place. A Phenomenology of the Uncanny. Athens: Ohio University Press.

Trotter, David. "The British Novel and the War." The Cambridge Companion to the Literature of the First World War. Ed. Vincent Sherry. Cambridge: Cambridge University Press. 34-56.

White, Hayden. 1975. Metahistory. The Historical Imagination in NineteenthCentury Europe. Baltimore and London: The Johns Hopkins University Press. 
Ross J. Wilson

(iD) https://orcid.org/0000-0001-6916-9419

University of Nottingham

\title{
Witnessing the Great War in Britain: Centenaries and the Making of Modern Identities
}

\begin{abstract}
As the centenaries of the events of the Great War are commemorated in Britain, a wave of new memorials and commemorative practices have been developed. These are additions to an already well-established 'landscape of memory,' with memorials built in the war's immediate aftermath across villages, towns and cities in Britain. This article examines these new sites of memory and mourning to reveal how social, moral and political identities within contemporary Britain are constructed through places that enable individuals and communities to 'bear witness' to the conflict.
\end{abstract}

\section{Memorializing the Great War}

The Great War possesses a prominent place within British culture and society. To even mention the war, or to refer to '1914-1918,' 'the trenches,' 'the Somme,' 'Gallipoli' or 'Passchendaele,' is to immediately evoke a powerful act of remembrance that connotes death, tragedy, suffering and pity (Wilson 2013, 3-5). Over the last decade, historians have demonstrated the way in which this memory of the war is an "invented tradition" (Bond 6; Todman 5; Corrigan 5). This scholarship has highlighted how the contemporary response to the war is born out of its representation on film, television, art and literature over the course of the twentieth century. This has created an image of the conflict that focuses on the stoic British "Tommy" on the Western Front, enduring the privations and horrors of industrial conflict (Badsey 113). Scholars have lamented this bias as preventing an understanding of the conflict as a complex, international event. However, whilst the meaning and memory of the war have been exposed to greater scrutiny what is not disputed is the status of the conflict in British society.

Over a century after its outbreak, with the last veterans having passed away ensuring the war is beyond 'living memory,' the war still has a presence within national narratives. In part, this is derived from the way the iconography of the conflict has become part of wider remembrance schemes of wars fought during 
the twentieth century (Iles 201-202). The date of November $11^{\text {th }}$, the Cenotaph in Whitehall, the two-minute silence to remember the dead and the poppy have become loaded with significance beyond the events of 1914 to 1918. Local war memorials in villages, towns and cities also reflect this extension of memory as these sites, which were built in the 1920s and 1930s, have been reused to commemorate the Second World War and the Korean War, too. The symbols of the Great War have also been used to frame the events surrounding the Iraq War and the Afghanistan War as the public, media and politicians use the conflict to interpret and understand contemporary events (Wilson 2014, 291-292). Therefore, the Great War has remained current within British society, as a point of reflection and remembrance on the past and the present.

However, despite the significance of this conflict and the prominence of war memorials and commemorative practices, the centenary of the Great War brought a new movement for memorialisation in Britain (see Harvey 107-108). Since 2014, sites of memory have been constructed or remembrance activities have been organised which mark the events of the conflict, the lives of those who were involved and seek to affirm the significance of the war for contemporary society (see Jeffery). These new sites act as places of witnessing, where the Great War and its impact can be felt and experienced by current generations. Within these locales, communities are called upon to act as witnesses, to bear testimony to the sense of loss, suffering and dislocation wrought by the war. Whilst the design and positioning of these memorials or the performance of new rituals of memory might vary from one another, the point of connection within this creation of memory is a sense of trauma (after Edkins). Whether large-scale memorials set for public display or small-scale commemorative plaques, the new sites of memory are places that emphasise mourning and bereavement.

The focus of this new remembrance on pain, suffering and loss is significant as it reveals how these new memorials are concerned with contemporary issues regarding identity across Britain rather than solely with the events of 1914-1918. The memorials and monuments that were built in the initial aftermath of the conflict were used to provide a sense of solace and meaning for the bereaved (see Heffernan). From the local war memorials, the corporate memorials for business and industries to the national sites of memory, the purpose of these places of memory was to affirm the significance of the sacrifice for 'God, King and Country' (King). Through their use and location at the centre of local and national life they subsequently became part of social memory. Succeeding generations have inherited this tangible and intangible legacy as the dead of the war has continued to be mourned (Gaffney). However, with the advent of the centenary this mourning was intensified with the creation of new memorials that accentuated loss. New memorials to the conflict reflect a continued engagement with the past but also a mode of expression about the present and the future as individuals witness the importance of this history and its meaning for contemporary society. 
The significance of the 'witness' is detailed within a legal and religious context in western culture, which requires acknowledgement, observance and testimony from the individual (see Derrida 75-79). As a first-hand observer or as a bearer of knowledge, the witness serves to ensure the remembrance of particular events (see Douglass and Vogler). Such acts of witnessing are not neutral records, but rather performances which enable the creation of memory that acknowledges the past and addresses the present (Apel; LaCapra). Significantly, this witnessing is bound by and defined by notions of space, place and purpose:

[...] places are witnesses, locales of memory that we mark out or that simply are there waiting, traces that serve to remind us of those things that need remember, for which there is a duty of one kind or another for us to bear witness. (Booth 111)

The new spaces that mark the war which have been created in Britain since the 1990s demonstrate how the role of bearing witness to the conflict of 1914-1918 reflects issues of identity, politics and power in contemporary society. The alternative sites of memory that have been constructed enable a mode of witnessing which denotes emotional, moral, political and social duties onto the individual as they are made to bear the burden of memory and by doing so testify to its significance in the present. Through the memorials to the conflict that have been formed since the eightieth anniversary of the war's outbreak, new witnesses to the conflict are formed which have altered practices of commemoration. In modern Britain, moral, social and political witnesses have been created within these new sites of memory. In this act of witnessing, individuals and communities build identities for themselves. As they engage with the remembrance of the war, they affirm or recreate a sense of self in relation to the conflict. Through the act of bearing witness, modern identities are defined.

\section{Political Witnesses and the Remembrance of the War}

Memorials reflect the active choices of groups and wider society as to what should be remembered and acknowledged (Wertsch). The memorials constructed in the years immediately following the end of the First World War bore this trait as they demonstrated the official concern for establishing the deaths of individuals as a sacrifice for the nation. Such meanings are not fixed, the practice of commemoration and use has altered the meaning of war memorials with regard to private grief and mourning. However, these acts are always undertaken within the physical, aesthetic and ideological framework provided by these sites of commemoration. The modern memorials to the conflict provide a similar space through which political witnesses to the war are formed. In these locations, 
memorials serve to reinforce issues of sacrifice and service for the cause of a wider purpose. These structures may emphasise local or national affiliation, but they act as sites of connection where the war extends an "imagined community" by emphasising a shared sense of loss (see Anderson). Within these memorials, the shock and suffering of the war is emphasised to establish a political link between groups within society. Rather than mobilising remembrance for social or moral action in the present, the act of political witnessing requires observance and testimony; within these sites witnesses are called forth to affirm the values held in common. In the remembrance of the Great War through the memorials constructed since 2014 in Britain, the act of political witnessing has reiterated a shared sense of self born through a collective remembrance of trauma (Alexander et al.).

The sense of shock, bereavement and grief is important as it is cements trauma and suffering as a foundation point within these new political identities. Where this has been most apparent is within the large-scale memorials to the conflict that have been constructed after 2014. Perhaps the installation of ceramic poppies around the Tower of London in the autumn of 2014 which was entitled "Blood Swept Lands and Seas of Red" is the most famous of the new memorials (Fig. 1). This artwork was assembled from 888,246 individual flowers to commemorate each of the lives lost by British or Dominion servicemen during the war. The formation of the memorial over several weeks, with the planting of the poppies made individually, drew widespread public and media attention. Indeed, on its completion on November $11^{\text {th }}$ it had already become a collective site of mourning for the nation as an estimated 4 to 5 million visitors were thought to have attended. The overwhelming sense of scale was key to this design by the artists Paul Cummins and Tom Piper. Visitors were confronted with a material manifestation of loss, seemingly evoking a powerful emotional response from all sections of society the which was reported widely within the media:

Manifest poppies bleed from a bastion window, they arc above its medieval causeway, and surge over the top of the walls - like infantrymen at the Somme - before saturating the Tower of London's 11th-century moat in a wash of crimson. Small wonder then that the world has been captivated by the unveiling of this astonishing artwork - part installation, part living theatre - designed to commemorate the centenary of World War One. On her visit this week, the Duchess of Cambridge was visibly moved to tears. (Lambert)

The emphasis on the commemoration of death, sacrifice and trauma was evident across the representation of the memorial. This reporting frequently referred to the significance of this site for the nation. As the project was finished with the last poppy arranged on Armistice Day, the way in which this installation reflected service to the state was apparent: 


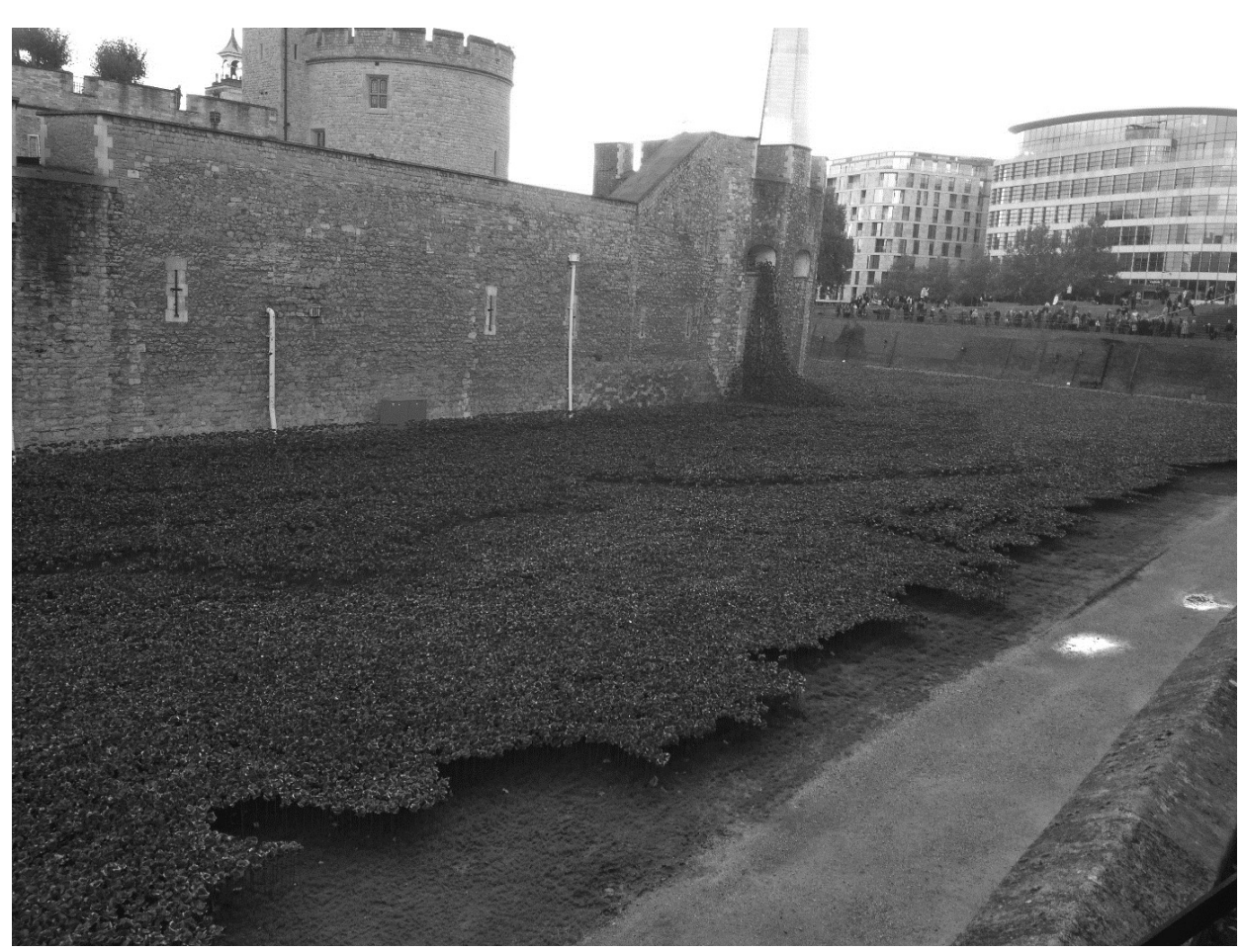

Fig. 1 - Blood Swept Lands and Seas of Red, Tower of London (Photograph by author)

They were the flower of British youth and they gave their lives for our freedom in the Great War a century ago. So it seems the perfect tribute that the Tower of London, a timeless symbol of our nation, should be weeping for them today, on Remembrance Sunday. (Bletchly)

Whilst the display was intended only to ever be temporary, such was the clamour from sections of the public and the media that the then Prime Minister David Cameron and Chancellor of the Exchequer George Osborne responded by supporting the development of the project into a touring exhibition (Anon 2014). Elements of the artwork were dismantled and rearranged and the dramatic piece known as the "Weeping Window" where ceramic poppies appear to flow down to the ground has been particularly prominent in local displays. These aspects of the original installation are to be displayed permanently at the Imperial War Museums in Manchester and London after their tour. In this manner, "Blood Swept Lands and Seas of Red" created a space where a shared sense of loss could be reflected upon. Significantly, this particular place of remembrance was not offered to emphasise a moral cause or perspective in the present but as a means of establishing collective witnesses to the service for the nation. Whilst certainly emotive and aesthetically stunning, this artwork was formed as a means of generating public recognition as 
to the scale of sacrifice during the First World War and thereby affixed a political identity through the act of witnessing. Through remembering trauma, a shared sense of national identity was asserted. This emphasised tradition and stability as the values of the nation were reaffirmed within these sites not brought to question or reassessment. As individuals witnessed the scale of death wrought during the war, they also witnessed the rehearsal of a core aspect of national identity.

Other temporary memorials or commemorative practices in Britain which were organised to mark the centenary of the outbreak of the war carried similar emphases on death, loss and the sacrifice of individuals for the nation. For example, the "Lights Out" programme held on August $4^{\text {th }} 2014$ where households and businesses across the country were encouraged to turn off any lights for an hour except for one single light from $10 \mathrm{pm}$ in a "shared moment of reflection" (14-18 Now). Inspired by the comments of the wartime Foreign Secretary Sir Edward Grey (1862-1933) that "the lamps are going out all over Europe," and organised by an arts initiative funded by the Imperial War Museum, the Heritage Lottery Fund and government offices, this action served to create a provisional and intangible commemorative spaces that focused on a sense of collective endeavour. Individuals, groups and communities were able to bear witness to the sacrifices made to the nation as the extinguished lights and solitary illumination emphasised the tragic loss wrought by the war. Indeed, this was how the event was represented within the media, the collective effort of remembrance was reiterated:

On the 100th anniversary since Britain joined the First World War, millions of people across the country reflected by the light of a candle on the sacrifices made by the young men and women during the Great War. (De Peyer)

As part of this event, the art installation named "Spectra," designed by the Japanese artist Ryoji Ikeda, was secretly unveiled. This piece, fashioned from 49 beams of light and installed by the Palace of Westminster to create a pillar of light that shone from dusk to dawn, formed a spectacle to witness and observe. Similar light shows were provided in Bangor, where the artist Bedwyr Williams presented a piece named "Traw" (from the Welsh meaning 'to strike'), which involved the projection onto the Memorial Arch of a series of images of soldiers killed during the conflict. The site of the Memorial Arch was significant as it had been part of the memorial landscape since its construction through public subscription in the 1920s. The interior of the Arch houses wooden plaques upon which the names of the dead from the local area are presented. In creating a new memorial site where one already exists the purpose of these modern places of remembrance is revealed as an intensification of cultural trauma (Alexander 2-3). Within "Traw," the faces of the dead serve as powerful reminders of the lives lost calling visitors to witness the dead. Significantly, there was no moral message to these displays, participants were called upon to witness and reflect on the dead but not to testify 
directly on any ethical stance on issues of peace, responsibility or reconciliation. That is not to say that such acts or locations are absent of meaning. They are highly important spaces as they reiterate a political identity through witnessing the trauma of the war. Through the act of collective observance, a sense of stability and tradition are reiterated through recognising death and mourning.

\section{Moral Witnesses and the Remembrance of the War}

Within the new spaces of memory created to mark the centenary of the war, another modern identity has been formed which presents an alternative vision of the conflict and seeks to address moral and ethical concerns. As part of a performance of remembrance or within permanent structures, moral witnesses are formed who are asked to testify as to the effect of the war (Margalit 147). This act of witnessing is frequently focused on retrieving some neglected aspect of the history of the conflict or addressing concerns in the present through the commemoration of the war. The specific agenda of these new forms of memory distinguishes this process from the political witnessing as well as the original memorial landscape constructed in the interwar era. These reflect a contemporary desire to revisit the past, to redress and to revise opinions and reveal the construction of a moral identity with relation to the war (Booth 12). These sites may be additions to existing places of memory or mourning or could be completely original additions to civic spaces. Their purpose is to offer an alternative vision of the conflict and to remind contemporary society of a moral duty in making amends for the past. Rather than reiterate a national narrative or political identity, these sites create a new space for engaging with what the conflict means in the present for individuals as they seek to forge a different engagement with the war. Moral witnesses are formed through sites and practices that require visitors not to just observe but to bear testimony to the events of the past and how these alter who groups and communities believe themselves to be in the present (Margalit 148-149).

Where this moral witnessing can be most clearly discerned is in the creation of memorials for those who were absent from the memorial schemes created in the aftermath of the conflict. This is associated with those termed as suffering from the mental trauma of the war and specifically 'shellshock.' In various places across Britain, new memorials remembering those who were regarded as experiencing shellshock have emerged during the centenary which ask contemporary society to rethink the remembrance of the war. In Croydon, south London, a memorial for twenty-six soldiers from the area who had been treated in the nearby mental hospital after their return from the front was erected in May 2016. The soldiers died whilst still institutionalised and their bodies were buried in mass graves at the site of the institution. A local campaign for recognition of these individuals saw three stones placed at Croydon Crematorium East Chapel that listed the names 
of those whose service had gone unrecorded on other memorials in the area. The memorial was regarded by those leading the initiative as a means of rectifying a past injustice and recognition of the pain and suffering that the individuals suffered during wartime (see Downey). As such, in the recognition of historical trauma, modern identities are formed as individuals and groups respond to the past by taking a moral stance (Margalit 148).

This formation of moral witnesses is undertaken at new sites constructed with the advent of the centenary but also through the alterations of existing memorials. In recent years, the names of soldiers executed during the war have been added to plaques and monuments as local campaigns successfully recognised the service of soldiers killed by their own army. Those individuals 'shot at dawn' are presumed to have been suffering from shellshock and their rescuing from obscurity or denial through commemoration is regarded as a responsibility and a duty. The war memorial arch in Guildford, located within the Castle Grounds of the town, was erected in 1921 but had not included one local individual in the list of names of the dead. Eric Skeffington Poole had been executed in December 1916 and as part of the commemorations for the centenary, in 2014 Poole's name was added to the memorial where he had previously been forgotten. Whether it is memorials from the interwar era or more recent memorials, sites have been amended to focus on the moral obligation to remember. This process can be observed with the alteration of the Newark Memorial to the Fallen in 2014. This site was only constructed in the 2000s, but the omission of Sapper William Pride who had committed suicide in 1918 at an army camp in Britain was rectified in 2014 with the addition of his name at base of the memorial. Family members and campaigners spoke about this process as an obligation and the inclusion of the memorial ensuring recognition for all participants in the war:

Sapper Pride's great granddaughter [...] said [...] "I always hoped that his name would be added and I am very pleased that it has been. I feel it is important that people see the names of the brave men who sacrificed so much." Mr Stevens (Commonwealth War Graves Commission) said it had taken a long time to sort the matter out. "In the end we have done what we set out to achieve," he said. "It is right and fitting that Sapper Pride's name is on the memorial." (qtd. in Parker)

Creating this new space of memory by the addition of names previously unacknowledged ensures a moral witnessing. Groups and communities are called together to remember the trauma of the war as a means of expressing a moral or an ethical stance. Similar perspectives of the moral witness have been formed through art installations which have used the issues of forgotten or neglected individuals or groups from the wider remembrance schemes of the war to create new places of commemoration. These sites specifically require visitors to re-evaluate and reconsider the experience of the conflict and impart a clear moral obligation with the 
performance of memory. The large steel statue of a British Army soldier sitting and staring at the floor is known locally as 'Tommy' after the archetypal soldier and was created by the artist Ray Lonsdale. The work was unveiled in Seaham, County Durham, in 2014 and officially entitled "1101" (or Eleven-O-One) to refer to the moment when the Armistice was declared. The artwork captures the exhaustion and trauma of the soldier whilst the poem placed on the plinth refers to the emotional and psychological damage created by the war at home and on the battlefield:

Now adrift in the wake of this glorious slaughter, [...] as lead tore the flesh from both friend and rival, $[\ldots]$ but heavy in his pocket lies a small piece of card, and the note written on it will break a mother's heart.

Art installations developed for the advent of the centenary frequently asserted a moral message for individuals to witness and engage with. In August 2014, around Chamberlain Square in Birmingham, the artist Nele Azevedo arranged 5,000 miniature ice sculptures of soldiers to represent the idea of loss. Both descendants of individuals killed in the war and relatives of those not named on war memorials were encouraged to place a frozen figurine before watching it melt away. The point of connection with the past was through a rehearsal of trauma and bereavement but the effect was to assert a moral vision of the cost of conflict. Since the advent of the centenary of the outbreak of the Great War, artists and designers have used the figure of the war poet Wilfred Owen (1893-1918), regarded as the tragic voice of the war, to emphasise the damage on bodies and minds that conflict caused but which is caused by contemporary wars, too. Sculptures, plaques and statues to Owen, both temporary and permanent, have been placed throughout Britain. In Edinburgh, where Owen was treated at the Craiglockhart Hospital for shell shock, a Peace Garden was unveiled in May 2017 at the Royal Highland Centre as part of Gardening Scotland event. The garden featured a sculpture of a soldier and a bust of Owen and it was planted by veterans of recent wars in Iraq and Afghanistan who have been treated for post-traumatic stress disorder. The purpose of the temporary garden was to establish a place where visitors could regard the past and the impact of this history on the present. One of the creators noted:

The sculpture of the unnamed serviceman and the bust of Wilfred Owen represent both those many thousands who lie with their names unknown to us, and those whose stories continue to be told to this day. (qtd. in McLaughlin)

In the new memorial spaces created after the centenary of the outbreak of the Great War, a moral vision of the remembrance of the conflict is forwarded to remind individuals of not just the duty of memory but a particular mode of commemoration. This represents a departure from the established narrative of the war's place within Britain; not as a point of collective identity but as a means of considering 
how the war altered the lives of individuals in the past and the implications of this for the present. Within these new spaces, moral witnesses are created that shape modern identities. These perceptions are also formed through a sense of cultural trauma to develop alternative associations to the conflict where remembrance is undertaken to actively assert a moral identity not dependent on national associations but on rectifying and redressing (after Margalit 149).

\section{Social Witnesses and the Remembrance of the War}

Where the most active engagement with the commemoration of the war through new memorials can be observed is within the context of social witnessing. Within this performance of memory, the conflict is used to foster civic spaces in the present, where contemporary society reconsiders issues of identity and the social connections that are made through commemoration. Social witnessing is a constructive event in this regard, establishing modern 'communities of memory' where individuals and groups build associations and new visions of what constitutes society. Rather than the inactive political witness or the reflective moral witnessing, the active engagement present within the social witness forms a testimony that alters ideas about identity. Within the construction of new memorials in Britain or commemorative practices that have been developed in the context of the centenary, an act of social witnessing is created that reforms the memory of the conflict and the way in which past, present and future are considered. This sense of community is still formed through the experience and evocation of cultural trauma; it is within that recognition of shared pain and bereavement that the social witness is created. The sense of trauma that is evoked within Britain in response to the war is an essential part of modern identity, it is used in a multiplicity of ways but it is the focus on mourning and suffering that is the common feature. This is the important aspect of the popular memory of the war that is misrepresented by revisionist histories of the conflict; the war is remembered as a tragedy because it is within that mode that the conflict possesses utility for contemporary society (Wilson 2013, 12).

The act of social witnessing with regard to the centenary can be observed within the local memorials or community memorials that have been constructed since 2014. These sites may draw attention to forgotten individuals but they also mobilise identities along the lines of a civic nationalism that is not exclusory and which attempts to create a new vision of society through the remembrance of the past (Mycock). This can be seen with the unveiling of the African and Caribbean War Memorial in Brixton, South London, in 2017. The memorial, designed as two plinths with one standing vertically and the other lying on its side, is dedicated to the military service of individuals of African and Caribbean heritage who served in both the total wars of the twentieth century. Whilst the memorial is not exclusively for the Great War, its initial installation outside the Black Cultural 
Archives (BCA) in London in 2014 and its relocation in 2017 coincided with the anniversaries of the conflict of 1914-1918. On the occasion of its first dedication at the archives, Dawn Hill, Chair of the BCA stated that:

BCA Trustees and Director Paul Reid, are honoured to share in this commemoration of African and Caribbean Service Personnel on this auspicious day 11 th November. It is indeed fitting that it will be installed in Windrush Square, Brixton. It will establish a constant source of inspiration to our Black \& Minority Ethnic communities of the valuable contribution made to Great Britain and the continuing heroic role of our soldiers in the present day. (AC Memorial)

As such, the memorial serves to reform ideas about contemporary citizenship and identity by referring to the trauma of the war through the commemorative architecture of the two plinths. In this social witnessing, visitors are asked to observe and to testify to the way in which this remembrance reshapes the present. Similarly, in Telford, Shropshire, a memorial garden was opened in October 2016 to mark the service of ethnic minority soldiers within the British Army during the Great War (Anon 2016). The temporary space was intended as a place of reflection but also as a place of peace with a concern to address bias and discrimination within contemporary society as well as to remember the past. In the formation of a community of mourning, drawn together through a recognition of a shared historical trauma, a new identity has emerged. This identity is based on reflecting the diversity of past and of contemporary society. This is more than providing a moral space to engage and rectify the errors of the past but a process of reforming the present through a new understanding of the history of the conflict.

These spaces can be formed from the large-scale events or small-scale memorials as groups and communities use the conflict to express how modern society should be constituted (after Assmann and Czaplicka). This sense of civic nationalism stands in stark contrast to the romantic nationalism formed through the act of political witnessing. This process is indicated with the dedication of a commemorative plaque in Edinburgh's Central Library which brought the names of over 500 British, Irish and Dominion nurses together who had either died in service, or, as a direct result of their involvement in the conflict. The plaque served as a means by which individuals who had not known one another during the war were arranged together in the present for the purposes of remembering the significance of these lives for contemporary society. The researcher for the project stated:

Nurses in the First World War were often casualties in just the same way soldiers were - with mothers, fathers and siblings waiting anxiously at home. It is with the support of our partners that we have been able to create the memorial plaque, helping to share their narrative and reveal some of the hidden histories of these remarkable women. (qtd. in Anon 2015) 
Through the focus on the trauma of the war and those who have been obscured from history, the plaque attests to the relevance of these individuals and the importance of remembering their lives and deaths together: it is a lesson in civic nationalism (after Knauer and Walkowitz). This can also be clearly discerned in the European War Memorial constructed in Woodvale Park in the Shankill area of west Belfast, Northern Ireland, and unveiled in October 2014. The memorial is made from stone quarried from the region and cut into a hexagon to replicate the structure of the basalt columns of the Giant's Causeway. Upon the memorial are dedications to those who served in the Belgian, British, French and German armies during the conflict (see Farrell). Designed as an 'inclusive' memorial it enables an act of social witnessing that extends the trauma of the war across national boundaries to find common points of connection. This issue is also central to the commemorative plaque unveiled near the People's Palace in Glasgow in April 2015. The memorial site is dedicated to the individuals and groups who campaigned against the war and promoted equality and tolerance within the city. The trauma present within the site is the repression and victimisation suffered by those dissenting individuals who refused to regard the war as legitimate. The wording of the memorial plaque provides a space for a civic identity to emerge as individuals witness the effect of the war on the past and present:

In memory of those who opposed WW1 in order to challenge the purpose of the war and the waste of lives. They also campaigned for social and economic justice and against the exploitation of those who lived in the city during the war.

Remembering those who have otherwise been obscured or forgotten is a moral act and the focus within these places of social witnessing is to act to reshape the present. Civic identities are constructed through the new memorial sites in relation to the events of the war but focused on reforming society. This has been a feature of the memorials erected to remember the lives of conscientious objectors during the Great War. Since the advent of the centenary, a number of proposals have been discussed by local charities and councils to mark the individuals who refused to participate in the war. In 2016, to mark the introduction of the Military Service Act 1916, which saw conscription of individuals and the definition of what constituted conscientious objectors, a memorial plaque was placed in the Peace Gardens in Harwicke Circus, Carlisle. This marked the experience and the suffering of those who did not participate in the war but also stated the relevance of this act for the present:

To commemorate all who have established and are maintaining the right to refuse to kill.

To be a social witness of the Great War is to look upon the memorials and commemorative practices and testify to the significance of this history and its 
relevance for contemporary life. Rather than a reiteration of identity through collective acts of memory, these places create a platform for a civic identity. This is not a fixed set of principles but rather a series of sites where values and ideals are redefined and new connections are made. As the trauma of the past is witnessed, a civic identity is formed within the new places of remembrance.

\section{Conclusion}

As the centenary of the Great War was marked in Britain, the creation of new memorials ensured that a conflict that was already an established part of the national narrative, was remembered all over again. This reiteration of the memory of the war is revealing as in the construction of these new places of mourning, individuals and communities demonstrated how the war still bears meaning for contemporary identities within Britain. Whilst the purpose and connections made with these expressions and definitions may be different they are all formed out of the sense of trauma associated with the war. The popular memory of the war in Britain focuses on the loss, death and pity of the conflict as it is through this sense of mourning and bereavement that the conflict maintains a function and use within identity politics. In the context of the new memorials to the war, this trauma was emphasised as it served as the basis for political, moral and social identities to be redefined. The commemorative sites that were initiated after 2014 enabled an act of witnessing for contemporary society. This practice is central to understanding the function of commemoration of the Great War in Britain. With the death of the last veterans of the war and the end of the 'living memory' of the events of 1914-1918, the conflict has not receded in its prominence. Rather, it maintains its significance because each generation since the Armistice has sought to bear witness to the conflict themselves. The role of the modern witness is to observe and acknowledge and in the context of the centenary it was to share or affirm a set of ideas about identity within contemporary society.

The witnesses to the war that were formed with relation to the new memorials and commemorative events that were planned for the centenary reflected the desires and the anxieties of early twenty-first century Britain rather than just a concern for the remembrance of the Great War. In an era when 'British' identity is being increasingly questioned and problematised, the remembrance of the war enabled a continuation of tradition as memorials that created political witnesses required collective observance of the conflict's importance for the nation. The grand commemorative schemes or extensive artworks all created a place where a shared sorrow could be mourned. Within these spaces, identity was not questioned nor was a new testimony regarding the war's importance sought. Instead, what was required was commitment and engagement; an act of witnessing without a call to proclaim the reason for remembrance. Whilst these places of political witnessing 
were some of the most prominent during the centenary of the Great War, there have been other forms of witnessing that have forged alternative identities in relation to the past and present. Moral and social witnessing have been present within the artistic works and commemorative structures that have been formed to rescue the memory of individuals and groups from a collective amnesia or to assert the importance of remembrance for a civic value. Within these places of commemoration, the trauma of the war is regarded as a means by which new communities of mourning are formed to build alternative identities, values and ideals. The commemoration of the centenary of the Great War in Britain has provided new spaces of memory for a conflict that was already well-remembered. In these locales stability is affirmed through collective acts of mourning, whilst in others, notions of identity have been redefined and alternative visions of the past, present and future have been constructed. Over a century after the outbreak, it is through the Great War that individuals, groups and communities continue to define themselves.

\section{References}

14-18 Now. "2014. Lights Out." http://www.1418now.org.uk/commissions/lightsout/ AC Memorial. "Statements." http://acmemorial.com/statements/

Alexander, Jeffrey C. 2012. Trauma: A Social Theory. Cambridge: Polity.

Alexander, Jeffrey C., Ron Eyerman, Bernard Giesen, Neil J. Smelser, and Piotr Sztompka. 2004. Cultural Trauma and Collective Identity. Berkeley: University of California Press.

Anderson, Benedict. 1991. Imagined Communities: Reflections on the Origins and Spread of Nationalism. New York: Verso.

Anon. 2014. "Prime Minister and charities secure future for Tower of London poppy display." https://www.gov.uk/government/news/prime-minister-andcharities-secure-future-for-tower-of-london-poppy-display

Anon. 2015. "Fallen nurses honoured." https://www.ed.ac.uk/news/2015/nursingmemorial-101115

Anon. 2016. "Telford war memorial and peace garden honours black and ethnic minority troops." Shropshire Star (October 4). https://www.shropshirestar.com/ news/2016/10/04/telford-war-memorial-and-peace-garden-honours-black-andethnic-minority-troops/\#HULQ9K0A3k7xZHdz.99

Apel, Dora. 2002. Memory Effects: The Holocaust and the Art of Secondary Witnessing. New Brunswick, NJ: Rutgers University Press.

Assmann, Jan and Czaplicka, John. 1995. "Collective Memory and Cultural Identity." New German Critique 65: 125-133.

Badsey, Stephen. 2001. "Blackadder Goes Forth and the 'Two Western Fronts' Debate." Television and History. Ed. Graham Roberts and Philip M. Taylor. Luton: University of Luton Press. 13-25. 
Bond, B. 2002. The Unquiet Western Front: Britain's Role in Literature and History. Cambridge: Cambridge University Press.

Booth, William J. 2006. Communities of Memory: On Witness, Identity, and Justice. Ithaca: Cornell University Press

Corrigan, Gordon. 2003. Mud, Blood and Poppycock. London: Cassell.

De Peyer, Robin. 2014. "As the lights went out, their memories burned bright: London pays tribute to WWI heroes with dramatic display." Evening Standard (5 August). https://www.standard.co.uk/news/london/london-plunged-intodarkness-in-to-remember-those-who-made-the-ultimate-sacrifice-9648287. html

Derrida, Jacques. 2005. Sovereignties in Question: The Poetics of Paul Celan. New York: Fordham University Press.

Douglass, Ana. and Vogler, Thomas A., ed. 2003. Witness and Memory: The Discourse of Trauma. London and New York: Routledge.

Downey, Andrea. 2016. "Memorial honouring forgotten WW1 soldiers unveiled at Croydon cemetery." Croyden Guardian (19 May). www.croydonguardian. co.uk/news/14504711.Memorial_honouring_forgotten_WW1_soldiers_unveiled_at_Croydon_cemetery/

Edkins, Jenny. 2003. Trauma and the Memory of Politics. Cambridge: Cambridge University Press.

Farrell, Nevin. 2014. "Unique memorial unveiled in Woodvale Park in tribute to World War One soldiers." Belfast Telegraph (18 October). www.belfasttelegraph.co.uk/news/northern-ireland/unique-memorial-unveiled-in-woodvalepark-in-tribute-to-world-war-one-soldiers-30673208.html

Gaffney, Angela. 1998. Aftermath: Remembering the Great War in Wales. Cardiff: University of Wales Press.

Heffernan, Michael. 1995. "For ever England: the Western Front and the politics of remembrance in Britain." Ecumene 2: 293-324.

King, Alex. 1998. Memorials of the Great War in Britain: The Symbolism and Politics of Remembrance. Oxford: Berg.

Harvey, David C. 2016. "Critical Heritage Debates and the Commemoration of the First World War: Productive Nostalgia and Discourses of Respectful Reverence During the Centenary. Heritage in Action: Making the Past in the Present. Ed. Helaine Silverman, Emma Waterton, and Steve Watson. Cham, Switzerland. 107-121

Iles, Jennifer. 2008. "In remembrance: The Flanders poppy." Mortality 13. 3: 201-221.

Jeffery, K. 2015. "Commemoration in the United Kingdom: A Multitude of Memories." Australian Journal of Political Science." 50. 3: 562-567.

Knauer, Lisa M. and Walkowitz, Daniel J. 2004. "Introduction." Memory and the Impact of Political Transformation in Public Space. Ed. Daniel J. Walkowitz and Lisa M. Knauer. Durham: Duke University Press. 1-18. 
LaCapra, Dominic. 1994. Representing the Holocaust: History, Theory, Trauma. Ithaca: Cornell University Press.

Lambert, Victoria. 2014. Row on row, the poppies flow at the Tower of London. The Telegraph (August 9). http://www.telegraph.co.uk/history/world-warone/11021743/Row-on-row-the-poppies-flow-at-the-Tower-of-London.html

McLaughlin, M. 2017. "Garden of peace to be created to honour war poet Wilfred Owen." The Scotsman (27 May). http://www.scotsman.com/lifestyle/ culture/books/garden-of-peace-to-be-created-to-honour-war-poet-wilfredowen-1-4459019

Margalit, Avishai. 2002. The Ethics of Memory. Cambridge: Harvard. University Press.

Mycock, A. 2014. "The First World War Centenary in the UK: 'A Truly National Commemoration?"' The Round Table: The Commonwealth Journal of International Affairs 103. 2: 153-163.

Parker, S. 2014. Sapper William Pride's name added to Newark war memorial after two-year campaign. Newark Advertiser (September 12). http://legacy. newarkadvertiser. co.uk/articles/news/Sapper-William-Prides-name-addedto-Newark-w

Todman, D. 2005. The Great War: Myth and Memory. London: Hambledon.

Wertsch, James V. 2002. Voices of Collective Remembering. Cambridge: Cambridge University Press.

Wilson, Ross J. 2013. Cultural Heritage of the Great War in Britain. Aldershot: Ashgate.

Wilson, R. 2014. "Sad Shires and No Man's Land: First World War Frames of Reference in the British Media Representation of the Iraq and Afghanistan Wars." Media, War and Conflict 7. 3: 291-308. 


\title{
Review
}

\author{
ANNA BRANACH-KALLAS and PIOTR SADKOWSKI, Comparing Grief \\ in French, British and Canadian Great War Fiction (1977-2014). Brill Rodopi \\ 2018, Leiden. ISBN 978-90-04-36477-6. 251 pages. (Katarzyna Więckowska \\ https://orcid.org/0000-0003-3408-3695)
}

In A War Imagined: The First World War and English Culture, published in 1990, Samuel Hynes famously claims that the war was not merely "the great military and political event of its time; but it was also the great imaginative event" which "altered the ways in which men and women thought not only about war but about the world, and about culture and its expressions" (ix). The war, as Hynes forcefully phrases it, "changed reality" (ix), putting an end to the established ways of thinking, systems of values, and modes of writing; it gave impetus to the process of "terminating faiths in progress, modernity, and rational systems of thought that had been sustained ever since the Enlightenment in the eighteenth century" (Stevenson viii), and radically destabilized the general belief in "a seamless, purposeful 'history' involving a coherent stream of time running from past through present to future" (Fussell 21). Writing about the war and its effects in 2013, over two decades after the publication of Hynes's seminal study, Randall Stevenson argues that the conflict, far from being forgotten, "refuses to remain buried in the past" (vii) and is kept alive not only by such collective practices as Armistice days, poppies, or war memorials, but above all by literature, the writing the war continues to produce (vii).

Comparing Grief in French, British and Canadian Great War Fiction (1977-2014) (2018) by Anna Branach-Kallas and Piotr Sadkowski attests to the widespread and continuing impact of the First World War, which it examines in a selection of British, French, English-Canadian, and French-Canadian novels written in the last forty years. Significantly, in contrast to the prevailing analytical framework, Branach-Kallas and Sadkowski do not focus on literary representations of combat and front life, but on texts that depict the long-lasting aftermath of the war in order to investigate the psychological and social effects of the conflict and to inquire into why the war refuses to be buried in the past. Comparing Grief explores the "changed reality" after the Great War and analyses the cultural trauma produced by the war in France, Canada, and Britain, focusing on shell-shock and the ensuing disintegration of individual identity and communal bonds. The examination of the manifold effects of the conflict concentrates on the 
personal, the local and the particular, so as to address the question "how did people suffer?" during and after the First World War (7). The book refers to numerous literary, sociological, historical, and philosophical studies to explore the links between the social and the individual, the political and the private, as well as the corporeal and the incorporeal. The key concept employed by Branach-Kallas and Sadkowski is that of grief, which they define, drawing on the work of Jay Winter and Judith Butler, as both a series of acts mediated through mourning and a state of mind which may prepare the ground for forming a (political) community (7) by "bringing to the fore the relational ties" that stress notions of "fundamental dependency and ethical responsibility" (Butler 22). Analysing various facets of grief and approaching grieving as a process, the authors stress connections between the past and the present, and point to those affective and ideological aspects of the Great War that continue to be important for contemporary writers, readers, and critics (10).

Comparing Grief presents an analysis of twenty-three novels written between 1977 and 2014 in France, Britain and Canada, thereby effectively disrupting the usual framework used for analysing Great War fiction which places it in the national context. It should be stressed that many of the novels have not been analysed yet, and that the comparative approach makes it possible to discuss a number of issues and problems across national denominations and to illustrate the global impact of the war without, however, erasing the differences between the nations and various national myths. Accordingly, in the five chapters that make the book, British, Canadian, and French fictions are examined to discuss recurrent themes and to outline the differences and similarities between the national literatures. The first chapter, Faces, is dedicated to the analysis of literary representations of facially disfigured soldiers and war veterans in The Officers' Ward (1998) by Marc Dugain, My Dear, I Wanted to Tell You (2011) by Louisa Young, Tell (2014) by Frances Itani, The Great Swindle (2013) by Pierre Lemaitre, and Toby's Room (2012) by Pat Barker. The second chapter focuses on the portrayal of women in war fiction, looking into the dominant constructions of gender, the gendering of war experience, and female grief and trauma in Alice Ferney's Dans la guerre (2003), Louisa Young's My Dear, I Wanted to Tell You (2011), Helen Dunmore's Zennor in Darkness (1993), Frances Itani's Deafening (2003), and Angélique Villeneuve's Les Fleurs d'hiver (2014). Chapter three, Communities, discusses the destruction and reconstruction of communal bonds during and after the war as represented in Philippe Claudel's By a Slow River (2003/2006), Louisa Young's The Heroes' Welcome (2014), Louis Caron's The Draft Dodger (1980), Daniel Poliquin's A Secret Between Us (2007), Jack Hodgins's Broken Ground (1998), and Robert Edric's In Desolate Heaven (1997). Chapter four focuses on the gendered representations of mourning during and after the war and explores the relations between intimate and collective remembrance in The Stone Carvers (2001) by Jane Urquhart, Toby's Room by Pat Barker, The Great Swindle (2013) by Pierre 
Lemaitre, and Le Monument (2004) by Claude Duneton. The final chapter of the book, Post-memory, offers an examination of collective and personal remembrance, and discusses the ways in which the war is remembered and re-constructed in Timothy Findley's The Wars (1977), Claude Simon's The Acacia (1989), Jean Rouaud's Fields of Glory (199), Robert Goddard's In Pale Battalions (1988), Sebastian Faulks's Birdsong (1993), and Olivier Barbarant's Douze lettres d'amour au soldat inconnu (1993). As the titles of the chapters indicate, Branach-Kallas and Sadkowski begin from the exploration of corporeal traces of the war in Faces, focus on those usually left out of narratives of combat in Women, consider the disintegration of social ties and the possibility of regaining a sense of belonging in Communities, and explore practices of grieving in Mourners, to conclude with a discussion of strategies of distancing and reconstructing memories of the war in Post-memory. Central to all these explorations is the question of ethics, which the authors examine in and across individual texts, various modes of writing, and practices of reading.

The chapter opening the book presents a disturbing, yet fascinating examination of facial disfigurement and its effects on personal and public life. Approaching loss of face as loss of self (14) and as a sign of human frailty (43), Anna BranachKallas explores "the stigmatising and sacralising potential of the mutilated face" (19) and carefully disentangles the various meanings of facial disfigurement, from a signifier of shame, dishonour and loss of masculinity, and a site of abjection, to a marker of courage and dignity, and a symbol of suffering and communal belonging through which personal identity may be reconstructed. To document the diverse aspects of corporeal damage, Branach-Kallas refers to military and medical histories in innovative and revealing ways, and situates the discussion within the fields of health, humanities, and disability studies. Accordingly, physical disfigurement is analysed from an existential, psychological, and social perspective, and in relation to the question of alterity and the ethical responsibility harboured in the mutilated face. "If the precariousness of life is communicated through the face of the Other," asks Branach-Kallas, then "what is communicated when the Other has literally lost his human face?" (40) The answers to the question document the ethical and aesthetic responses to facial injuries during the conflict and signal the existence of a "hidden history" of the First World War (50). They also indicate that the cognitive and corporeal crisis precipitated by otherness may recur, and that it may lead to various reactions, including those exemplified by the practice of masking the facial wound, interpreted here as a sign of "the society's desire to forget the war and move forward" (213). Drawing on the work of Emmanuel Levinas and Judith Butler, Branach-Kallas stresses the productive potential of grief and the ethical dimension of the encounter with corporeal disfigurement and loss both in literature and in real life, and examines the ways in which the soldier's alterity and precarity fundamentally question social, political, and aesthetic norms, destabilizing the very idea of "the human." 
The second chapter, by Anna Branach-Kallas, interrogates the prevailing representations of war as an archetypal masculine experience (52) by focusing on the marginalisation of women in war discourses and literature, and by foregrounding the female experience of war. Branach-Kallas uses the concept of "quiet or family trauma" (58), developed by E. Ann Kaplan, to analyse the experience of women in war fiction. She refers to Sara Ruddick's idea of maternal thinking and links it with First World War feminist pacifism to describe as "maternal pacifism" the representation of "attentive love as a model of non-violent relationships" in war literature (60-61). The analyses presented in the chapter clearly demonstrate the pernicious effects of the gendering of war and the conservative ideology disseminated by war propaganda, which worked to dismiss or ignore the trauma suffered by women. Emphasising the uniqueness of each trauma, the author convincingly argues for the recognition of the importance of female suffering and the traumatisation of the civilian population during the Great War. As Branach-Kallas states, although the recent shift to cultural history and history of emotions has re-focused critical attention on women, "a variety of women's experience has so far been unexplored: that of elderly women, married women, and those from the peripheries" (52). The concept of "asymmetric similarities" (81-82) proves particularly useful in discussing literary representations of male and female trauma, or military and domestic suffering, making it possible to discern illuminating similarities between, for example, military surgery and cosmetic facial treatments, as well as other individual and public practices which reveal the vulnerability shared by soldiers and civilians alike.

The various ways in which public conflicts and disasters intervene in the private sphere are a recurring theme of Comparing Grief and they are the explicit focus of the third chapter, where Branach-Kallas and Sadkowski analyse the destruction and reconstruction of real and imagined communities. The notion of community, as the authors note, plays a very important role in discussing a conflict which was presented at its outbreak as a universal struggle against "the onrush of organized barbarism" (Kipling 106) in defence of civilization and democracy - or, as Ford Maddox Ford famously put it, as a battle for "the culture of the future, the very life and heart of the future" (xx). Starting with the vision of the war as an event that was to "usher a new dimension of human interaction" (88) transgressing all existing divisions, Branach-Kallas and Sadkowski discuss the images of egoism and brutalisation that counter the ideals of the community of August 1914 and that both express and reinforce "the anxiety about the crisis of humanity caused by the First World War" (133). A key issue in the formation and recognition of communities is visibility, which becomes particularly significant in the case of facially disfigured war veterans, whose "monstrosity," while excluding them from the larger (normative) community, may create the basis for forming communities of a different kind. Against the background of growing social disparity and division, Branach-Kallas and Sadkowski discuss several 
such "new" communities, real and literary, which translate grief into a productive experience (89) and which realize "the possibility of community on the basis of vulnerability and loss" (Butler 20). The examples of such social groups presented in this chapter include a community of adoptive kinship, described by Jay Winter as formed "through a process of informal or figurative 'adoption"" (Branach-Kallas and Sadkowski 97), and a community of memory, where the shared memory of the war provides ways for constructing a better future (111). While these "new" types of communities use the memory of the war in constructive ways, the authors point also to instances in which the past can and has been used to build a sense of separateness that reinforces national myths and conflicts (124) and stress the "profound sense of disillusionment, emptiness, and rupture with the past" (128) that makes the post-war communities particularly precarious and ambivalent.

Mourners, by Anna Branach-Kallas and Piotr Sadkowski, examines another global community created by the Great War and discusses the rituals of private and collective mourning that appeared after the war in an effort to come to terms with the past and bereavement. Analysing mourning and melancholy in the framework established by Sigmund Freud and developed by Nicolas Abraham and Maria Torok, the authors describe various stages of private and public grieving, drawing attention to the problem of who was and who was not allowed to mourn. The fact that "heroic status was strictly regulated during the Great War" (155), and that it continues to be variously distributed among disparate social groups, is illustrated through references to literary works and history, discussed within the context of the problem of grievability - the question of whose lives should and should not be grieved (163). An example of such exclusionary practices is the gendering of mourning, demonstrated by the absence of fathers and men from the funeral ceremonies during the First World War (156). The chapter explores various forms of communal and private mourning, including the construction of public memorials, and ironically depicts "the cult of mourning," painfully mocked through the trafficking in bodies in Pierre Lemaitre's The Great Swindle. Ultimately, as Branach-Kallas and Sadkowski prove, the memory of the Great War lingers on as "infinite grief" and "interminable mourning" (167), resurfacing as the responsibility to bear testimony to the past that has become an inevitable part of the present.

The work of memory, the lingering of trauma, and the need to reconstruct the past are the major focus of the final chapter of the book, Post-memory, where Piotr Sadkowski approaches the First World War as effecting "a crisis of affect, testimony, and imagination" (174). Employing the concept of post-memory developed by Marianne Hirsch, the author analyses fictions depicting instances of inheriting the trauma of the 1914-1918 conflict by children or grandchildren of war participants (175). The novels analysed in the chapter are examples of what Dominique Viart calls filiation narratives, in which fiction and historical and biographical research are mixed "to expose dramatic events in the protagonists" 
family history" (175). Sadkowski stresses the necessarily mediated nature of history, where examining the enigma of the past leads to a confrontation with "scars, wounds, and traumatic effects, which are experienced indirectly by the post-memory biographer and reader" (181), as well as emphasizes the fragmented and uncertain status of post-memory (196). Featuring a return to the painful past, the texts analysed by Sadkowski stage "an act of sepulchre," where the re-discovery of familial history disrupts the boundaries between past, present, and future, thereby testifying to unfinished mourning (191). Whether driven by the desire to reconstruct the genealogical tree, to rediscover one's identity, or to turn the "mythologised hero" into "a man of flesh and blood" (210), such texts, frequently trough the use of metafictional devices, force their readers to take part in the exercise in "mnemonic empathy" (182) and to become "witness[es] of the process of reconstruction of the traumatic past" (179).

Comparing Grief is the first book-length study offering a comparative reading of recent French, British and Canadian Great War fiction which describes the global impact of the war, examining the ways in which the conflict has been variously re-incorporated into national narratives and myths, and outlining the diverse effects of the cultural trauma of the war. Branach-Kallas and Sadkowski approach the First World War from the contemporary perspective and historicize their own critical intervention so as to uncover the "current concerns, such as alterity, gender, trauma, mourning, precarity, dissent and communality" that shape the understandings of the 1914-1918 conflict and its representations (219). Referring to literary and cultural studies, sociology, philosophy, and history, the book presents an overview of not only recent Great War literature, but also of First World War scholarship and contemporary critical approaches to cultural texts and practices. While Comparing Grief contains numerous revealing insights, the chapters dedicated to facial disfigurement, women, and communities seem to merit special attention, because of the transdisciplinary approach they adopt, the gaps they fill in, and their relevance to the present (global) situation. Commenting on the fact that the Great War refuses to remain buried in the past, Branach-Kallas and Sadkowski suggest that the reasons for its endurance "might result from our deeply hidden anxieties about a war that has not yet come" (221-222). This is an anxiety that is intricately linked with grief, the emotion that "challenge[s] the very notion of ourselves as autonomous and in control" (Butler 23) and that, as the authors argue, is used by contemporary novelists to "unsettle the readers and engage them ethically" (222). Comparing Grief, as well as the texts analysed therein, testifies to the contemporary "desire to enter into a dialogue with the past" (212), to confront the haunting presence of the First World War, and to yet again face its many ghosts, acknowledging that "One cannot not have to, one must not be able to reckon with [spirits], which are more than one: the more than one/no more one" (Derrida $\mathrm{x}$ ). 


\section{References}

Branach-Kallas, Anna, and Piotr Sadkowski. 2018. Comparing Grief in French, British and Canadian Great War Fiction (1977-2014). Leiden: Brill Rodopi. Butler, Judith. 2004. Precarious Life: The Powers of Mourning and Violence. London, New York: Verso.

Derrida, Jacques. 1994. Specters of Marx: The State of the Debt, the Work of Mourning, and the New International. Trans. Peggy Kamuf. New York: Routledge.

Ford, Ford Madox. 1915. When Blood Is Their Argument: An Analysis of Prussian Culture. London: Hodder and Stoughton.

Fussell, Paul. 2000. The Great War and Modern Memory. Oxford, New York: Oxford University Press.

Hynes, Samuel. 1990. A War Imagined: The First World War and English Culture. London: Bodley Head.

Kipling, Rudyard. 1915. "As They Tested Our Fathers." New York Times, Current History. New York: The New York Times Company. 106. https://www. gutenberg.org/files/13635/13635-h/13635-h.htm\#page106

Stevenson, Randall. 2013. Literature and the Great War 1914-1918. Oxford: Oxford University Press. 



\section{CONTRIBUTORS}

ANNA BRANACH-KALLAS (Ph.D., D.Litt.) is Associate Professor in the Department of English at Nicolaus Copernicus University, Torun, Poland. She is the author of Uraz przetrwania. Trauma i polemika z mitem pierwszej wojny światowej w powieści kanadyjskiej ["The Trauma of Survival: The (De)Construction of the Myth of the Great War in the Canadian Novel"] (2014), which was awarded a Pierre Savard Award by the International Council for Canadian Studies. She has also co-authored, with Piotr Sadkowski, Comparing Grief in French, British and Canadian Great War Fiction (1977-2014) (Brill/Rodopi, 2018). She has published two other books and over seventy essays, which express a range of interests from intertextuality and historiography to corporeality, trauma, war, and postcolonialism. She is also the co-editor of several essay collections, including Re-Imagining the First World War: New Perspectives in Anglophone Literature and Culture (2015). Since 2009, she has directed the Canadian Studies Resource Center at Nicolaus Copernicus University. Currently, she is director of a comparative project devoted to the analysis of representations of the Great War in contemporary fiction in England, France and Canada.

DONNA COATES is Associate Professor in the English Department at the University of Calgary. She has published more than two dozen articles and book chapters on Canadian, Australian, and New Zealand women's responses in fiction and drama to the First and Second World War, the Vietnam War, and contemporary warfare. With Sherrill Grace, she has selected and edited Canada and the Theatre of War: Volume One, First and Second World War Plays (2008) and Canada and the Contemporary Theatre of War, Volume Two (2010). With George Melnyk, she has published Wild Words: Essays on Alberta Literature (2009) and Writing Alberta: Building on a Literary Tradition (2017). In 2015, she edited Sharon Pollock: First Woman of Canadian Theatre. For Routledge Press' History of Feminism Series, she has edited seven volumes on the subject of women and war (forthcoming).

MARJORIE GEHRHARDT (Ph.D.) is Lecturer in French history at the University of Reading, UK. Her research focuses on war and its representations in twentieth-century Europe, with a particular interest in the reintegration of veterans and the role of charities in wartime. She has published numerous articles on the experiences and depictions of French, British and German facially injured combatants and her book The Men with Broken Faces: Gueules Cassees of the First World War (Peter Lang) came out in 2015. Her current research investigates 
the impact of the First World War on philanthropic activities and the contribution of organisations, large and small, to the war effort in Great Britain and France in particular.

NANCY SLOAN GOLDBERG is Professor of French language and literature at Middle Tennessee State University. She has published widely on French poetry and novels of the Great War, including En l'honneur de la juste parole and Woman, Your Hour is Sounding: Continuity and Change in French Women's Great War Fiction. Her most recent publications include "Une grande âme n'est jamais seule: la réception poétique contemporaine d'Au-dessus de la mêlée" and "Challenges and Contradictions in Teaching French Great War Literature" for the Modern Language Association series, Teaching Representations of the First World War.

MARTIN LÖSCHNIGG is Associate Professor of English at the University of Graz, Austria. His main research interests are narrative theory, autobiography, the English novel, the literature of the First World War, and Canadian literature, and he has published extensively on these subjects. Book publications on World War I literature: Der Erste Weltkrieg in deutscher und englischer Dichtung [The First World War in German and English Poetry] (Heidelberg 1994); Intimate Enemies: English and German Literary Reactions to the Great War 1914-1918 (co-ed. with Franz K. Stanzel; Heidelberg 1993, $2^{\text {nd }}$ edn. 1994); The Great War in Post-Memory Literature and Film (co-ed. with Marzena Sokołowska-Paryż; Berlin and Boston 2014); North America, Europe and the Cultural Memory of the First World War (co-ed. with Karin Kraus; Heidelberg 2015). Forthcoming: The First World War Then and Now: Literature, Theatre and the Arts (co-ed. with Sherrill Grace and Waldemar Zacharasiewicz) Focus Issue Anglistik: International Journal of English Studies 29. 2 (2018); The Enemy in Contemporary Film (co-ed. with Marzena Sokołowska-Paryż; Berlin and Boston 2018).

SARA PRIETO, Ph.D., teaches British and American literature at the University of Alicante, Spain. Her research focuses on the literature of the First World War, with special emphasis on male and female civilian eyewitness accounts on the war, as well as on propagandistic approaches to the war. She is also interested in other conflicts such as the Spanish Civil War. She is the author of Reporting the First World War in the Liminal Zone: British and American Eyewitness Accounts from the Western Front (Palgrave 2018), she has co-edited Literary Journalism and World War I: Marginal Voices (PUN 2016) and has also published in Edith Wharton Review and First World War Studies.

ANNE SAMSON is an independent historian specialising in the First World War in Africa, in particular East, South and Central. She is co-ordinator of the Great War in Africa Association which is a free association of people interested 
in researching aspects of the war on the African continent. Anne completed her $\mathrm{PhD}$ in History at Royal Holloway, University of London in 2004 with her thesis Britain, South Africa and the East Africa Campaign 1914-1918: the Union Comes of Age subsequently published by IB Tauris in 2005. Her most recent monograph, World War 1 in Africa: The Forgotten Conflict of the European Powers (IB Tauris 2013) was published in paperback in September 2018. She has numerous journal articles on aspects of World War 1 in Africa and has been involved in a number of edited volumes such as The Lake Tanganyika Expedition 1914-1917: A Primary Source Chronology (GWAA 2016 in conjunction with The (UK) National Archives).

MARZENA SOKOŁOWSKA-PARYŻ is Associate Professor at the Institute of English Studies, University of Warsaw, Poland, where she teaches courses on contemporary British and Commonwealth literature, with specific emphasis on war fiction and film in relation to history, memory and national identity. She is the author of Reimagining the War Memorial, Reinterpreting the Great War: The Formats of British Commemorative Fiction (2012) and The Myth of War in British and Polish Poetry, 1939-1945 (2002). She has co-edited, with Martin Löschnigg, The Great War in Post-Memory Literature and Film (2014) and The Enemy in Contemporary Film (forthcoming 2018).

NATALIA STACHURA, Ph.D., independent researcher, in 2013-2016 post-doc researcher in HERA-founded project Cultural Exchange in a Time of Global Conflict: Colonials, Neutrals and Belligerents during the First World War. She has published on film propaganda during the Great War, South African postmodern literature, colonialism and cultural transfer. Her main publications include: Allied and German Film Propaganda in the Netherlands, 1914-1918 (2017, Wydzial Anglistyki UAM), Przestrzeń intertekstualna i geohistoryczna w powieściach André P. Brinka (2016, Wydawnictwo Naukowe UAM), ("Vondel's Lucifer Translating the Text, Translating the Culture," in: Doing Double Dutch The International Circulation of Literature from the Low Countries, 2017 Leuven University Press), ('Want de Oosterling is voor niets zoo toegankelijk als voor het levende beeld op het projectie-doek.' The Battle of the Somme in Nederlands-Indië, in: 'Plots hel het werd'over Jacobus van Looy en The Battle of the Somme, 2016, Huis Clos).

RŪTA ŠLAPKAUSKAITÉ, Ph.D., is a literary scholar and lecturer based at Vilnius University, Lithuania. She teaches a number of courses, including Literary Theory, Things, Bodies, and Texts, the Canadian Short Story, and Multiculturalism in Literature. Her research interests include neo-Victorian fiction, memory and material visuality, and the significance of material culture. Among her recent publications are "The Material of Memory in Helen Humphreys' The Lost Garden, Transcanadiana, 2017; "Et in Arcadia Ego: Memory, Mystery, and Mourning in J. L. Carr's A Month in the Country," in Re-Imagining the First World War: 
New Perspectives in Anglophone Literature and Culture (Cambridge Scholars Publishing, 2015); and "Intermedial Translation: The Gyrating Gaze in David Dabydeen's Turner," in the European Journal of English Studies 18. 3 (2014).

ROSS J. WILSON is Assistant Professor and Director of Liberal Arts at the University of Nottingham, UK. His research interests encompass the experience, representation and memory of the First World War. He also focuses on wider issues of museum, media and heritage representations in the modern era. He has written extensively on these issues and his work includes, Landscapes of the Western Front: Materiality During the Great War (2012), Cultural Heritage of the Great War in Britain (2013), New York and the First World War: shaping an American City (2014), The Language of the Past (2016) and Natural History: Heritage, Place and Politics (2017). He is also the editor of Representing Enslavement and Abolition in Museums (2011) and Gender and Heritage (2018). 